CONSELHO NACIONAL DE DESENVOLVIMENTO CIENTIFICO E TECNOLOGICO (CNPq.) INSTITUTO NACIONAL DE PESQUISAS DA AMAZONNIA (INPA)

\title{
Madeiras do Município de Aripuanã e suas utilidades (Mato Grosso)
}

Arthur A. Loureiro

Pedro L. Braga Lisboa

INPA. - Manaus

ACTA AMAZONICA Vol. 9(1): Suplemento

Manaus-Amazonas 
LOUREIRO, Arthur A.

Madeiras do Município de Aripuanã e suas utilidades. Mato Grosso. Acta Amazonica, Manaus, 9(1) : Suplemento, mar. 1979. $88 \mathrm{p}$. ilust.

Colaboração de P. L. B. Lisboa

1. Madeiras - Aripuanã (MT) 2. Tecnologia de madeira 3. Produtos florestais - Aripuanã (MT) I. Lisboa. Pedro Luiz Braga II. Título.

CDD.

18. Ed.

CDU.

674.8811

674(811.3)

643.98811

$634.0 .8(811.3)$

RESUMO: Os autores apresentam o estudo anatômico macroscópico de 63 espécies madeireiras. Para cada uma, são apresentadas as seguintes indicaçōes: nome científico e vulgar, área de ocorrêncio, habitat, caracteristicas gerais da madeira, descriçāo macroscópica, empregos, e tabelas dos características físicas e mecânicas de algumas espécies. llustram o trabalho dois atlas, um mostrando fotos da face transversal das madeiras aumentadas 10X para facilitar a identificação e outro mostrando a face tangencial para se ter uma visão de conjunto da beleza dessos madeiras e do paralelismo axial dos elementos constituintes do lenho em relaçäo ao eixo do tronco. 
Introdução $\ldots \ldots \ldots \ldots \ldots \ldots \ldots \ldots \ldots \ldots \ldots \ldots \ldots \ldots \ldots \ldots \ldots \ldots \ldots \ldots, \quad 5$

Agradecimentos $\ldots \ldots \ldots \ldots \ldots \ldots \ldots \ldots \ldots \ldots \ldots \ldots, 6$

Glossário dos termos utilizados na descrição macroscópica

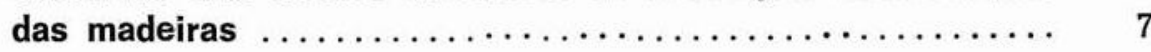

Dados gerais sobre as espécies e respectivas descrições

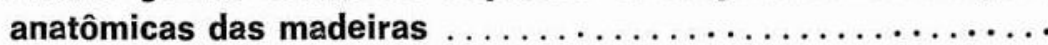

Tabela das características físicas e mecânicas de algumas espécies

Atlas das macrofotografias das secções transversais das es-

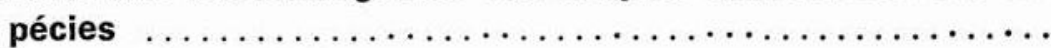

Atlas das macrofotografias da face tangencial em relação ao eixo do tronco de algumas espécies $\ldots \ldots \ldots \ldots \ldots \ldots \ldots$

Summary $\ldots \ldots \ldots \ldots \ldots \ldots \ldots \ldots \ldots \ldots \ldots \ldots \ldots \ldots \ldots \ldots \ldots \ldots \ldots, \quad 77$

Bibliografia $\ldots \ldots \ldots \ldots \ldots \ldots \ldots \ldots \ldots \ldots \ldots \ldots \ldots \ldots \ldots \ldots \ldots \ldots \ldots, 78$

Índice alfabético dos nomes vulgares $\ldots \ldots \ldots \ldots \ldots \ldots \ldots, \quad 80$

Índice alfabético dos nomes científicos $\ldots \ldots \ldots \ldots \ldots \ldots . \quad 87$ 


\section{INTRODUÇ ÃO}

O Município de Aripuanã, Mato Grosso, situado entre as coordenadas $7^{\circ} 19^{\prime} 45^{\prime \prime}$ e $12^{\circ}$ $22^{\prime} 30^{\prime \prime}$ de latitude sul e $55^{\circ} 54^{\prime} 61^{\circ} 31^{\prime} 15^{\prime \prime}$ de longitudo oeste e, a uma altura de 200 a $300 \mathrm{~m}$, tem sido objeto de pesquisas florestais nos últimos anos o que tem representado uma boa contribuição para o conhecimento da flora fanerogâmica e criptogâmica daquela região.

Como o município é coberto $90 \%$ por floresta amazônica, e já há no momento um crescente interesse pela exploração comercial de madeiras naquela região bem como uma intensificação de pesquisas florestais, sobretudo pela presença, na área, do Instituto Nacional de Pesquisas da Amazônia (INPA) com o Projeto Aripuanã sediado no Núcleo de Humbolát, em Dardanelos.

O escoamento fluvial e terrestre das madeiras do Aripuanã são provavelmente as dificuldades maiores que afetam os empresários de madeiras do município e por outro lado, com a tradição exploratória de madeiras, provenientes de região de várzea, na Amazônia, o entusiasmo pelas matas de terra firme do Aripuanã ainda não entusiasmou os interessados.

Dos $140.078 \mathrm{~km}^{2}$ de área do município, aproximadamente $40.000 \mathrm{~km}^{2}$ estão destinados à exploração econômica e essa imensa área é constituída de $90 \%$ de matas de terra firme, o que nos dá uma idéia do seu grande potencial madieireiro. Assim, com a construção da Rodovia Humboldt-Vilhena, supõe-se que a região deverá atrair os empresários, possibilitando com isso a instalação de serrarias na região. Atualmente apenas duas serrarias funcionam em Dardanelos, uma pertecente ao INPA, cuja produção é destinada apenas ao uso do Nứcleo de Humboldt e a outra, particular, que não atende à demanda do município, sendo por isso necessário o transporte de madei- ras de Vilhena até a Vila de Dardanelos. É fácil, portanto, deduzir-se que um importante centro madeireiro não tem sido ainda aproveitado como exportador.

Sobre o aspecto das espécies produtoras de madeiras, é notável a ocorrência significativa de espécies, que, no momento, são consumidas ávidamente pelas indústrias do sul, como por exemplo a Cerejeira (Torresia acreana), Mogno (Swietenia macrophylla), Peroba (Aspidosperma polyneuron), etc., além de outras que ainda não o são por falta de conhecimento de suas propriedades físico-mecânicas e divulgação, o que, sem dúvida viria derrubar a barreira do "tradicionalismo" do meio empresarial, que recusa sistematicamente a introdução de novas madeiras no mercado, acarretando com isso uma perda inestimável do nosso patrimônio florestal.

A deficiência de estudos tecnológicos de madeira, gradativamente será suprimida com os estudos elaborados pelo Centro de Tecnologia da Madeira de Cuiabá (CTM), da Secretaria de Produção, bem como pelo advento da implantação de um centro de estudos madeireiros, no Instituto Nacional de Pesquisas da Amazônia, nos próximos anos.

Baseando-nos no fato de que o comércio madeireiro na região amazônica é prejudicado não só pelo pouco conhecimento das propriedades das madeiras, como, basicamente pela precária possibilidade de uma boa identificação, sobretudo devido a variação do nome vulgar dentro da própria região amazônica, foi que decidimos elaborar este primeiro volume sobre as madeiras do Município de Aripuanã, no qual procuramos dar uma pequena parcela de contribuição ao conhecimento das madeiras que lá ocorrem. Dois atlas acompanham o trabalho, um mostrando fotos da face transversal das madeiras aumentadas $10 \mathrm{X}$ para facili- 
tar a identificação e outro mostrando a face tangencial para se ter uma boa visão da beleza dessas madeiras, e do paralelismo axial dos elementos componentes em relação ao eixo do tronco.

\section{AGRADECIMENTOS}

Agradecemos ao Dr. Inaldo Cavalcanti Figueiredo, eminente Coordenador do Projeto Aripuanã, pelo apoio e incentivo dado para à realização de nossa pesquisa; ao Dr. Benedito
Décio Realino pela doação de amostras de madeiras da xiloteca do CTM de Cuiabá; ao Senhor Luiz Coelho pelo auxílio na identificação botânica de algumas espécies.

Agradecemos ainda ao Dr. Pedro Ivo Soares Braga, pelas macrofotografias da face tangencial das madeiras; aos auxiliares técnicos Wilson Meirelles, Darlinda Bastos e Manoel Moacir Pereira pela colaboração.

Expressamos nossos sinceros agradecimentos ao desenhista Jorge Palheta, pelos desenhos esquemáticos que ilustram esse trabalho. 


\section{GLOSSÁRIO DOS TERMOS UTILIZADOS NA DESCRIÇÃO MACROSCÓPICA DAS MADEIRAS(")}

\begin{abstract}
Alburno - Camada externa do lenho situada entre o cerne e a casca da árvore, composta de elementos celulares ativos, e caracterizada por ter geralmente coloração clara.

Anéis porosos - Ocorrem em certas madeiras quando os poros maiores se concentram no limite das camadas anuais de crescimento.
\end{abstract}

Aspecto fibroso - É o contraste observado nas superfícies das secções longitudinais de certas madeiras entre massas do tecido fibroso e do parênquimatoso, intercaladas.

Camada de crescimento - Sucessão de anéis ou camadas concêntricas vistas na secção transversal quando polida, corresvondentes ao lenho produzido aparentemente durante cada período de crescimento.

Camadas fibrosas - São camadas estreitas constituídas quase que exclusivamente de tecido fibroso e que se apresentam na secção transversal, regulares, afastadas e concêntricas, aparentemente delimitando camadas de crescimento.

Câmbio - Camada de tecido meristemático que dá origem ao xilema e floema na estrutura secundária.

Canais secretores - Condutos ou espaços tubulares intercelulares, geralmente servindo como depósito de resinas, gomas, etc.

Canais secretores horizontais ou radiais - Pequenos condutos que se estendem no sentido radial, e que são notados na face tangencial como pequenos pontos escuros dentro dos raios lenhosos. Em certas espécies são pouco perceptíveis, mesmo com lente.

Canais secretores verticais ou axiais Pequenos condutos resinosos ou gomosos que se estendem paralelamente às fibras e são vistos na secção transversal como pequenas cavidades," isoladas ou em séries.
Cerne - Parte interna do lenho da árvore envolvida pelo alburno. geralmente caracterizada por coloração mais escura que este, e por ser constituído de elementos celulares já sem atividades vegetativa.

Descrição macroscópica - Observação dos tecidos lenhosos quando vistos a olho nu ou com auxílio de uma lupa de $10 \mathrm{X}$ de aumentos.

Diâmetro tangencial - É o diâmetro dos poros medidos na secção transversal, no sentido perpendicular dos raios.

Elemento vascular ou Segmento vascular - Um dos componentes celulares de um vaso.

Fibra - Elementos celulares longos, fusiformes e de paredes relativamente grossas, formando em conjunto o tecido fibroso responsável pela maior ou menor resistência da madeira. Individualmente não são visiveis sob lente de 10X de aumentos. O tecido fibroso raramente oferece ao exame macroscópico elementos de identificação.

Floema incluso - Manchas ou camadas de floema incluídas no xilema de certas dicotiledôneas.

Grã - Termo empregado com referência à direção ou paralelismo dos elementos constitutivos das madeiras em relação ao eixo do tronco.

Lenho - Segmento qualquer do tronc) ou raiz, constituído de tecidos responsáveis pela sustentação e condução da água e sais minerais.

Líber - Principal tecido da condução das substâncias nutritivas nas plantas vasculares (parte interna da casca).

Linhas vasculares - Canalículos ou cavidades alongadas, que aparecem como linhas interrompidas, mais ou menos paralelas nas

(*) - De acordo com Mainieri \& Pereira, 1958. 


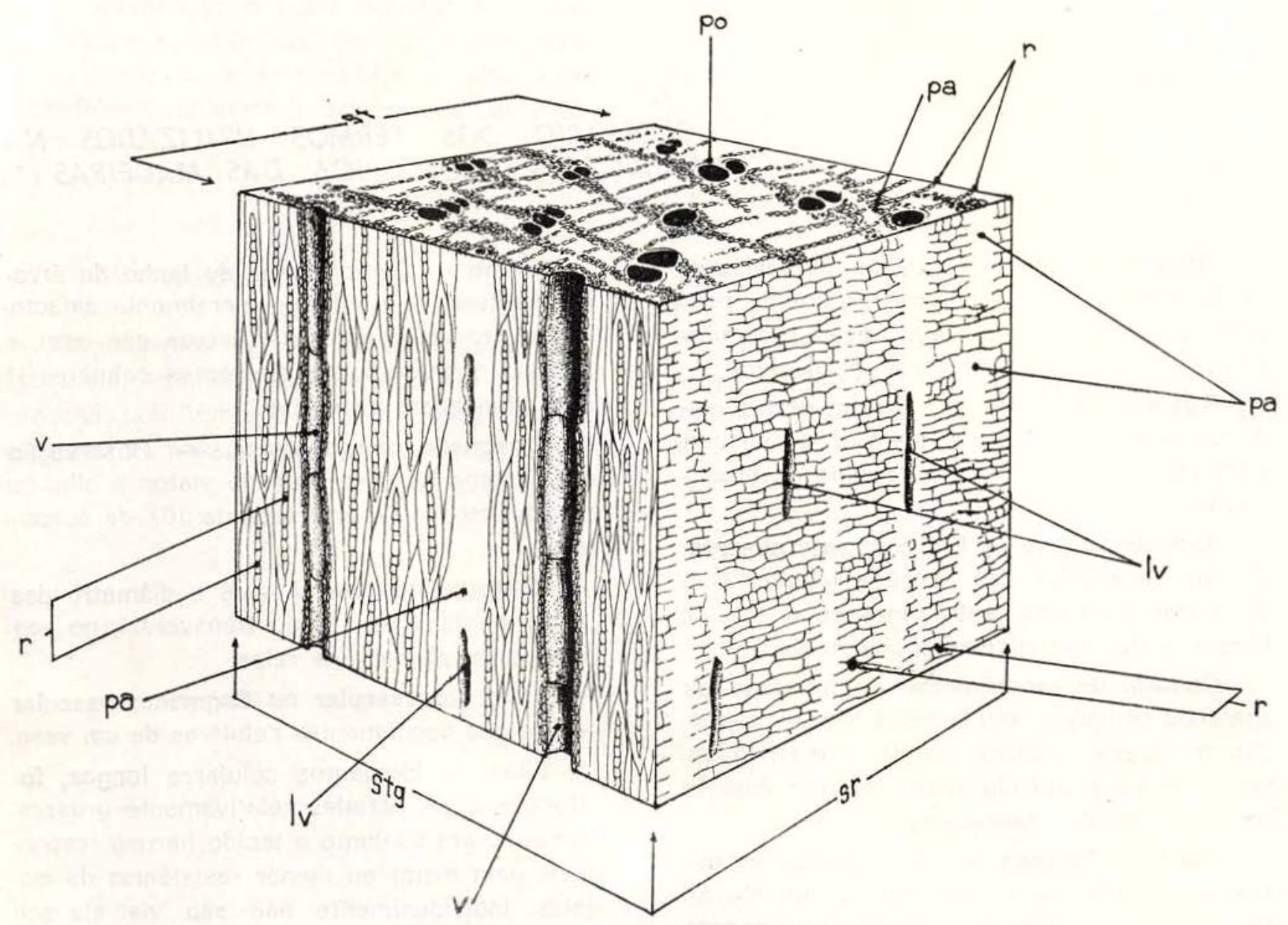

Desenho esquemático do aspecto macroscópico de madeira, com três planos de corte: St - Superfície transversal; Sr - Superfície radial; Stg - Superfície tangencial; po - Poros; $r$ - raios lenhosos; pa - Parênquima; $1 \mathrm{v}$ - Linhas vasculares; V - Vasos.

superfícies longitudinais da madeira. São resultantes do corte longitudinal dos vasos.

Lúmen - Cavidade de cada elemento celular.

Máculas medulares - Pequenas manchas claras irregulares, lenticulares, que aparecem na superfície do topo, visíveis às vezes a olho nu, constituídas por tecido parenquimatoso cicatricial, e que geralmente são provenientes de ferimentos no câmbio causados por insetos. Nas superfícies tangencial e radial aparecem como estrias.

Parênquima - Tecido frouxo, de regra mais claro que a parte fibrosa do lenho, por ser constituído de células curtas, iguais, de paredes finas; classifica-se em: parênquima axial ou longitudinal parênquima radial.
Parênquima axial - Parênquima que ocorre na massa do lenho, envolvendo ou não os vasos. A sua disposição e abundância observadas na superfície transversal, são característicos básicos na identificação das madeiras.

Parênquima aliforme - Parênquima axial que se dispõe em tôrno dos poros estendendo-se opostamente: a) em expansões largas e curtas. b) em prolongamentos laterais, longos e finos, cujas extremidades podem ligar-se ou não com as dos poros vizinhos.

Parênquima concêntrico ou zonado - $\mathrm{Pa}$ rênquima axial que dispõe em linhas ou em faixas nitidamente concêntricas, aproximadas ou não. 
Parênquima confluente - Ocorre quando o parênquima axial vasicêntrico, aliforme, ou mesmo o paravascular conjuga-se resultando na formação de trechos, longos, largos e irregulares, às vezes com tendência para faixas concêntricas.

Parênquima confluente obliquo - Ocorre quando o parênquima axial vasicêntrico, ou aliforme, ou mesmo o paravascular conjuga-se em trechos curtos tomando disposição oblíqua em relação aos raios lenhosos.

Parênquima difuso - Ocorre quando células do parênquima axial se distribuem escassa e isoladamente entre as fibras.

Parênquima radial - Tecido parenquimatoso que constitui os raios lenhosos; é de es. trutura idêntica a do parênquima axial.

Parênquima reticulado - Parênquima axial que se dispõe em linhas regulares e aproximadas, cruzando-se quase perpendicularmente com os raios lenhosos.

Parênquima terminal ou inicial - Parênquima axial que se dispõe em faixas largas, regulares ou não, mas, afastadas, e que aparentemente delimitam as camadas de crescimento.

Parênquima em trama - Ocorre quando células do parênquima axial se dispõe em pequenos segmentos lineares, muito finos, aproximados formando com os raios uma trama fina e irregular.

Parênquima vasicêntrico - Ocorre quando o parênquima axial se apresenta abundante ao redor dos poros, formando uma auréola de largura variável, circular ou ovada, muitas vezes visível a olho nu, circundando tanto os poros solitários como os múltiplos, freqüentemente apresenta escassas confluências.

Poros - (Freqüência) - Quanto à freqüência os poros podem ser classificados em:

Pouco ............ até 3 por $\mathrm{mm}^{2}$

Pouco numerosos ... de 4 a 7 por $\mathrm{mm}^{2}$

Numerosos ........ de 8 a 12 por $\mathrm{mm}^{2}$

Muito numerosos ... acima de 12 por $\mathrm{mm}^{2}$

Poros - (Tamanho, diâmetro tangencial) - Quanto ao tamanho de poros podem ser classificados em:
APOTRAQUEAL

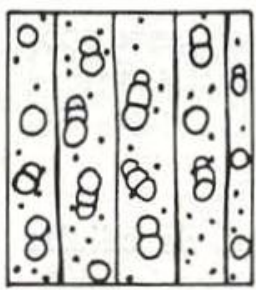

1

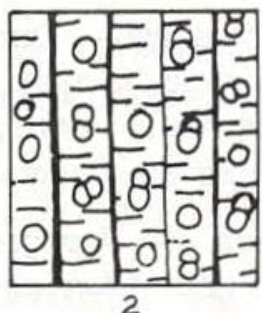

PARATRAQUEAL
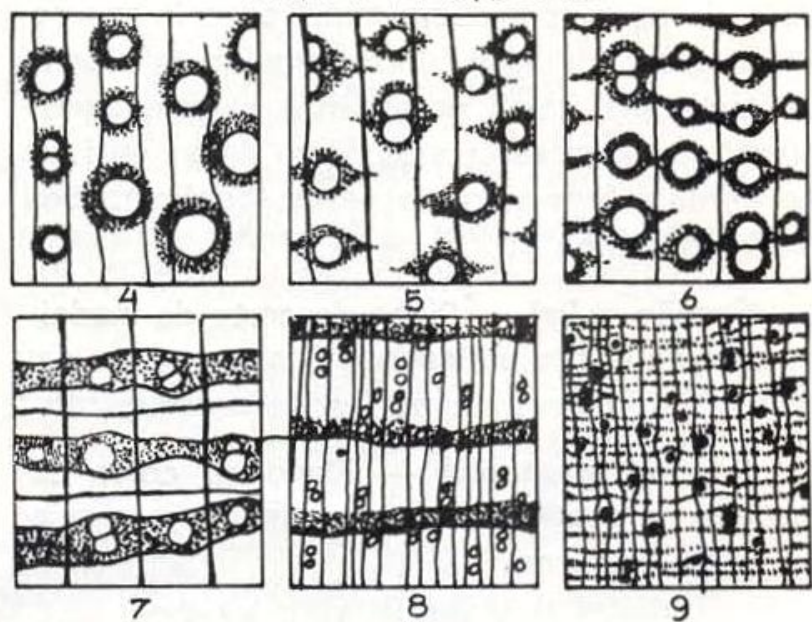

6

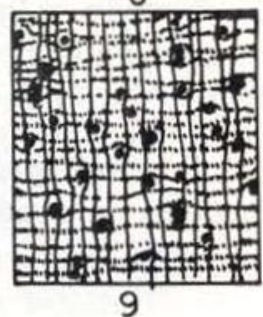

9
Desenho esquemático dos principais tipos de parênquima axial usados para descrição anatômica das madeiras : 1 - Difuso; 2 - Difuso agregado; 3 Concêntrico; 4 - Vasicêntrico; 5 - Aliforme simples; 6 - Aliforme confluente; 7 - Faixas confluentes; 8 - Faixas terminais; 9 - Reticulado.

Muito pequenos $\ldots \ldots \ldots$ até $100 \mu$

Pequenos .............. $100-200 \mu$

Médios ............... $200-300 \mu$

Grandes ............. mais de $300 \mu$

Poros em cadeia - Poros solitários adjacentes dispostos em séries radiais.

Poros geminados - Conjunto de dois poros adjacentes, cujas paredes de contacto aplanadas, parecem na secção transversal como uma sub-divisão de um poro solitário.

Poros múltiplos - Conjunto de 3 ou 4 poros, justapostos, formando grupos.

Poros solitários - Poros completamente circundados por elementos celulares de modo irregular. 
Raios não estratificados - Quando se dispõe na superfície tangencial de modo irregular.

Raios estratificados - Quando se dispõe regularmente na superfície tangencial arrumados de modo a formarem séries paralelas que se distribuem como em andares.

Raios lenhosos - Agregados de células parenquimatosas arrumadas no sentido radial em relação ao eixo da árvore. Na superfície de topo aparecem como numerosas linhas retilíneas aproximadas, geralmente mais claras; na tangencial toma geralmente a forma ienticular; na radial são vistos como linhas ou fitas horizontais formando, às vezes, configurações distintas a olho nu.

Secção radial - Plano de corte da madeira paralelo aos raios lenhosos normalmente em ângulo reto com as camadas de crescimento.

Secção tangencial - Plano de corte da madeira no sentido axial e em ângulo reto com os raios lenhosos.
Secção transversal - Plano de corte da madeira perpendicular às fibras. Secção onde melhor se observam as várias disposições dos tecidos do lenho para fins de identificação.

Textura - Termo empregado com referência ao tamanho e a freqüência dos elementos constitutivos da madeira.

Tilos - Proliferação de certas células do parênquima axial ou radial para o interior de um elemento vascular adjacente, através de uma pontuação da parede obturando, total ou parcialmente, o vaso. Macroscopicamente aparecem nas secções transversais como obstruções lamelares e brilhantes dos poros.

Traqueídos - Elementos celulares geralmente longos, peculiares às Coniferas, e com funções que se equiparam às das fibras e a dos vasos. Em certas espécies são visíveis sob lente na superfície transversal.

Vasos - Série vertical de células coalescentes (Elementos vasculares) que formam uma estrutura tubiforme do comprimento indeterminado. 


\section{DADOS GERAIS SOBRE AS ESPÉCIES E RESPECTIVAS DESCRIÇÕES ANATOMICAS DAS MADEIRAS}

\author{
AMAPÁ \\ Brosimum utile subsp. ovatifolium (Ducke) \\ C.C. Berg \\ BRASIL - Amapá (Mato Grosso, Amazonas, Pará \\ e Acre). Leiteira (Amazonas). VENEZUELA - \\ Marina.
}

ÁREA DE OCORRÊNCIA

$\mathrm{Na}$ Amazônia brasileira ocorre nos Estados de Mato Grosso (Aripuanã). Amazonas (Manaus), Pará (Gurupá) e Acre (Boca do Acre). Na Amazônia geográfica aparece ainda no Peru, Venezuela, Colômbia e Guiana Francesa.

\section{HaBitAT}

Mata de terra firme, em solo argiloso, porém aparece também em locais inundáveis.

\section{CARACTERÍSTICAS GERAIS DA MADEIRA}

Madeira moderadamente pesada $(0,60$ a $0,65 \mathrm{~g} / \mathrm{cm}^{3}$ ); de cor creme palha passando com o tempo ao creme sujo; grã irregular; textura grosseira; cheiro e gosto indistinto. Fácil de trabalhar, recebendo brilho acentuado.

\section{DESCRIÇÃo MACROSCópica (Foto 1)}

Parênquima apenas perceptível a olho nu, contrastado, aliforme de aletas longas e finas que confluem dando às vezes a impressão de parênquima em linhas terminais. Poros visíveis a olho nu, pequenos a médios, solitários predominantes, múltiplos de 2 e 3 , vazios. $L i$ nhas vasculares retas, largas, vazias, bem visíveis a olho nu. Raios no topo visíveis a olho nu, apresentando boa uniformidade na largura e espaçamento; na face tangencial perceptíveis a olho nu, irregularmente dispostos; na face radial contrastados. Camadas de crescimento mal definidas. Máculas medulares e canais secretores não foram observados.

\section{EMPREGOS}

Móveis, estacas, esteios, marcenaria, construções em geral.

\section{AMARELINHO}

\section{Zanthoxylum sp.}

BRASIL - Amarelinho, Mato Grosso (Aripuanã).

ÁREA DE OCORRÊNCIA

Mato Grosso (Aripuanã), Amazonas (Manaus) e Território do Amapá (Serra do Navio).

\section{HaBitat}

Mata de terra firme, solo argiloso.

Características Gerais DA MAdeira

Madeira pesada $\left(0,70-0,80 \mathrm{~g} / \mathrm{cm}^{3}\right)$, compacta, amarelo-vivo, brilhante; grã irregular; textura média; cheiro e gosto indistintos.

\section{DESCRIÇÃo MACROSCÓPICA (Foto 2)}

Parênquima contrastado, em faixas terminais, bem visíveis a olho nu, irregularmente espaçadas entre si. Poros notados a olho nu devido a conteúdo claro, pequenos, poucos, solitários e múltiplos, predominando os primeiros; obstruídos. Camadas de crescimento pouco visíveis a olho nu, baixas. Raios no topo visiveis a olho nu os mais grossos; na face tangencial irregularmente dispostos; na face radial pouco contrastados. Camadas de crescimento aparentemente demarcadas pelo parênquima terminal. Máculas medulares e canais secretores não foram observados.

\section{EMPREGOS}

Construção em geral. 
AMEIXA

\section{Drypetes variabilis Vittien}

BRASIL - Ameixa.

ÁREA DE OCORRÊNCIA

Ocorre nos Estados do Mato Grosso (Aripuanã), Amazonas e Território do Amapá.

\section{Habitat}

Matas de terra firme, sobre solo argiloso.

\section{Características gerais Da Madeira}

Madeira pesada $\left(0,80-0,90 \mathrm{~g} / \mathrm{cm}^{3}\right)$, dura; branca, passando com o tempo para creme escuro ou pardo acinzentado; textura fina à média; superfície pouco lustrosa; grã direita; cheiro e gosto não pronunciados. Fácil de trabalhar com qualquer ferramenta. Fende-se com facilidade.

\section{DESCRIÇÃo MACROSCópiCA (Foto 3)}

Parênquima pouco contrastado mas distinto sob lente, em finíssimas linhas irregulares quase contínuas, aproximadas, ou aparentemente difuso, formando com os raios uma trama muito fina. Poros apenas visíveis à simples vista, pouco numerosos, pequenos, solitários predominantes, múltiplos de 2-3, alguns de 4, ocasionalmente de 5-6 poros, raríssimos obstruídos. Linhas vasculares longas, retas, contendo no seu interior substâncias da cor do lenho. Raios no topo são finos, numerosos, apenas perceptíveis a olho nu os associados; na face tangencial irregularmente dispostos, pouco perceptíveis mesmo com ajuda de lente; na radial são contrastados, não bem definidos. Camadas de crescimento bem definidas e demarcadas por faixas escuras, compac. tas de tecido fibroso. Máculas medulares e canais secretores inaparentes.

\section{EMPREGOS}

Construção civil e naval.

\section{AMOREIRA}

Chlorophora tinctoria (L.) Gaud.

BRASIL - Amoreira, Limorana, Mato Grosso (Aripuanã). Tacajuba, T. de espinho, Limão-rana, L. amarelo, Amoeira brava, A. de espinho, Moratana, Runa, Tatajiba, Tatayba, Tatayuva, Tatayuba, Ta taiba, Pau amarelo, Taúba, (Amazonas). Amoeira, Tatagiba, (Minas Gerais e Bahia). Taxaúva (São Paulo). Tajuva, (Rio G. do Sul)

Denominações estrangeiras e comerciais: Amarillo, Bois jaune, Fustic, Fusticwood, Fustiuholz, Mora amarilla, Tatagiba.

ÁREA DE OCORRÊNCIA

Ocorre na Amazônia em geral, e no sul do país desde Minas Gerais até Santa Catarina; comum no interior de São Paulo, Sul de Goiás, nas regiões do rio Apa, Mato Grosso do Sul, alto Paraguai e no Rio Grande do Sul.

\section{HABITAT}

Freqüente nas florestas primárias ou secundárias de solo úmido ou seco, também nas várzeas argilosas da Amazônia. Na América Central é encontrada nas pastagens, xerofíticas, e nas savanas.

\section{CARACTERÍSTICAS GERAIS DA MAdeIRA}

Madeira pesada $\left(0,75\right.$ a $\left.0,80 \mathrm{~g} / \mathrm{cm}^{3}\right)$; cerne amarelo vivo quando fresco ou amarelo limão quando recém-cortado, passando para o castanho avermelhado em exposição ao ar; alburno mais claro; grã variável; textura média; superfície um pouco lustrosa; lisa ao tato ou ligeiramente áspera; sem odor e gosto distinto. Fácil de trabalhar, recebendo bom acabamento. É resistente à decomposição.

\section{DESCRIÇÃo MACROSCóPICA (Foto 4)}

Parênquima relativamente abundante, pouco perceptível a olho desarmado, confluente e paravascular, apresentando faixas concêntricas irregulares, estreitas ou em prolongamentos laterais curtos, formando trechos oblíquos. Poros apenas notados a olho desarmado, de pouco a pouco numerosos, médios, solitários na sua maioria, geminados e em pequenas cadeias radiais obstruídos na sua totalidade por 
tilos brilhantes. Linhas vasculares são notados a olho desarmado, retas e longas. Raios no topo são numerosos, finos e bem distribuídos, apenas perceptíveis a olho desarmado; na face tangencial apresentam-se irregularmente dispostcs; na face radial são contrastados. Camadas de crescimento pouco distintas. Máculas medulares e canais intercelulares não foram observados.

\section{EMPREGOS}

Construção navais, carroçaria, obras expostas, moirões, dormentes, carpintaria, ebanisteria, tábuas, cercas e esteios.

\section{ANANI}

\section{Symphonia globulifera L.}

BRASIL - Ananim, Mato Grosso (Aripuanã). Anani (Amazonas e Pará). Canandí, Vanandí, Uanandi, Guananim vermelho (Maranhão e Bahia).

GUIANA - Mani, Maniballi, Brick-wax-tree, Karimanni. G. FRANCÊSA - Manil, Manil-parcouri. SURINAME - Matakki, Mataaki, Manni, Masagrie, Cok-wel-mani. COLÔMBIA - Macharé. VENEZUELA - Mani, Faraman. PERU - Brea-caspi. PANAMÁ - Cerillo, Sambogum, Boncillo. HONDURAS - Waika, Chewstick. GUATEMALA - Barillo, Leche amarillo. GABÃO - Azoli. INDIAS ORIENTAIS INGLESAS - Boarwood, Doctor gum.

\section{ÁREA DE OCORRÊNCIA}

Largamente distribuída em toda a Amazônia. Registrada ainda para Pernambuco, Bahia, Espírito Santo, Rio de Janeiro, Guianas, Panamá, Jamaica, Honduras, Angola.

\section{HaBitat}

Geralmente nos igapós ou na terra firme em solo arenoso úmido, em toda a Amazônia.

\section{Características gerais DA Madeira}

Madeira moderadamente pesada $(0,65$ a $0,75 \mathrm{~g} / \mathrm{cm}^{3}$ ); cerne bege rosado ou róseo claro uniforme; alburno bege bem claro, um tanto destacado do cerne; superfície lisa, pouco lustresa; grã direita; textura média; sabor e gosto indistintos. Fácil de trabaihar, podendo receber acabamento esmerado.

\section{DESCRIÇÃo MACROSCÓPICA (Foto 5)}

Parênquima abundante, visível a olho nu, porém não muito contrastado, em faixas um tanto largas, aproximadas, irregulares, sinuosas, ligando os poros, notando-se também algum aliforme simples. Poros visíveis sem auxílio de lente, médios a grandes, poucos, solitários em maioria, alguns agrupados em 2-3 poros, resina oleosa e tilos comuns, brilhantes. Linhas vasculares distintas à simples vista, altas e retas, vazias e com resina oleosa amarelada. Raios no topo finos, numerosos, apenas notados a olho nu, não muito realçados no fundo fibroso, destacando-se os mais grossos, um tanto afastados; na face tangencial pouco perceptíveis mesmo sob lente, altos, irregularmente dispostos; na face radial são contrastados. Camadas de crescimento na maioria das vezes indistintas, quando presentes são demarcadas por zonas fibrosas escuras. Máculas medulares freqüentes, chegando a ser notadas a olho nu. Canais secretores não foram observados.

\section{EMPREGOS}

Móveis, construção em geral, caixas, utensílios domésticos, tanoaria, dormentes, carpintaria, compensado, pasta para papel, esquadrias, estacas, aduelas.

\section{ANGELIM PEDRA}

\section{Hymenolobium petraeum Ducke}

BRASIL - Angelim pedra (Mato Grosso, Aripuanã e Amazonas). Murarena (Amapá, Macapá e Roraima).

ÁREA DE OCORRÊNCIA

Distribuída por toda a Amazônia brasileira.

\section{HaBitat}

Florestas altas de terra firme; também nos campos altos, onde o porte, embora reduzido, prevalece sobre os demais.

\section{Características gerais Da Madeira}

Madeira muito pesada $\left(0,90\right.$ a $\left.1,00 \mathrm{~g} / \mathrm{cm}^{3}\right)$; cerne rosado claro ou castanho escurc, com 
acentuadas riscas mais claras de aspecto fibroso; grã irregular; textura grosseira; superfície lisa ao tato; cheiro e gosto indistintos. Difícil de trabalhar, recebe acabamento esmerado.

\section{DESCRIÇÃo MACROSCÓPICA (Fotos 6 e 64)}

Parênquima muito abundante, bem distinto à simples vista, vasicêntrico, aliforme simples e com prolongamento em faixas longas e interrompidas, bem largas, outras mais finas, algumas concêntricas regulares, onduladas e em trechos oblíquos. Poros bem visiveis a olho nu, poucos, médios a grandes, solitários e agrupados, raros de 3, vazios. Linhas vasculares freqüentes, longas e retas. Raios no topo apenas notados a olho desarmado, bem visíveis com o auxílio de lente, finos e um tanto numerosos, apresentando boa distribuição na largura e espaçamento, na face tangencial apresenta estratificação (2 a $3 \mathrm{p} / \mathrm{mm}$ ), nem sempre regular; na face radial são contrastados. Camadas de crescimento demarcadas por zonas fibrosas mais escuras sem parênquima e poros. Máculas medulares e canais secretores não foram observados.

\section{EMPREGOS}

Carpintaria, marcenaria, dormentes, estacas, tacos de soalhos, construção civil e naval, vigamentos, esteios, etc.

\section{ARAPARI}

\section{Macrolobium acaciifolium Benth.}

BRASIL - Arapari, Mato Grosso (Aripuanã). Arapari, A. verdadeiro, A. da várzea, Amazonas (Manaus). Faveira, Fava de tambaqui, Arapari e Para caxi (Pará, rio Tapajós, etc.). Arapari (Maranhão). Arapari, Raparigueira (Ter. Amapá).

\section{ÁREA DE OCORRÊNCIA}

Ocorre nos Estados de Mato Grosso (Aripuanã), Amazonas (com relativa abundância), Pará, Acre e Territórios do Amapá, Rondônia e Roraima, também no Estado de Goiás, Guianas e partes amazônicas do Peru e Colômbia.

\section{HABITAT}

Cresce espontaneamente e com relativa abundância nos lugares sujeitos a inundações temporárias, na margem dos rios, lagos e campos baixos da Amazônia.

\section{Características gerais Da Madeira}

Madeira moderadamente pesada $(0,60-$ $0,65 \mathrm{~g} / \mathrm{cm}^{3}$ ); cerne castanho-avermelhado; alburno pardacento; grã geralmente direita; textura média; cheiro e gosto indistintos. Não é difícil de trabalhar, recebendo acabamento atrativo, de lustre mediano, curvando-se bem.

\section{DESCRIÇÃo MACROSCÓPICA (Foto 7)}

Parênquima relativamente abundante, em geral do tipo paratraqueal, visível sob lente, pouco contrastado, aliforme, abrangendo dois ou mais poros, vasicêntrico de pouca confluência, e em faixas terminais afastadas, às vezes duplas. Poros visiveis a olho desarmado, poucos, pequenos a médios, solitários, agrupados de 2-3 poros, ovalados, vazios. Linhas vasculares perceptíveis à simples vista, um tanto altas e retas. Raios no topo são finos e numerosos, visíveis somente com auxílio de lente, apresentando uma certa uniformidade na largura e espaçamento; na face tangencial aparecem curtos e irregularmente dispostos, na radial apenas notados a simples vista. Anéis de crescimento demarcados por zonas fibrosas mais escuras e compactas do lenho tardio, ainda faixas concêntricas do parênquima apotraqueal concêntrico, estreito. Máculas medulares e canais secretores não identificados.

\section{EMPREGOS}

Carpintaria, marcenaria, caixas, celulose para papel, tábuas de boa qualidade. É empregada na fabricação de móveis vergados. É bem flexível, tomando formas variadas.

\section{ARARA TUCUPI}

Parkia pendula Benth.

BRASIL - Arara tucupi, Visgueiro (Mato Grosso - Aripuanã e Amazonas, Manaus). Visgueiro, Boloteria, Rabo de arara, Jupuúba, Fava bolota, ( $\mathrm{Pa}$ rá, Belém, Bragança, etc.). Faveira de chorão (Ma- 
ranhão). Visgueira, Joerana, Joeirana, Arara petiu, Fava de bolota, Faveira de berloque, Faveirão, Joarana, Juerana, Jupiuba, Jupuúba, Macaqueira, Mafua, Muirarema, Muirareina, Paricá, Pau de arara, Procaxi, Sabiu, Pau de sândalo (Bahia). Visgueiro (Pernambuco). SURINAME - Kwatakama, Ipana. GUIANA FRANCESA - Male bois macaque, Acacia mâle (Creole); Kouatakaman (Pamaka e Saramaka); Ipanai, Hipanai (Demerara). Grignon fou.

ÁREA DE OCORRÊNCIA

Comum nos Estados de Mato Grosso (Aripuanã), Amazonas e Pará, e observada ainda nas Guianas. Estados de Pernambuco, Bahia e Alagoas.

\section{HABITAT}

Comum na mata primária ou secundária da terra firme, em solo argiloso, é ainda muito comum "nas margens dos rios de barrancos, da terra firme".

\section{Características gerais DA MAdeira}

Madeira pesada $\left(0,80-0,85 \mathrm{~g} / \mathrm{cm}^{3}\right)$; cerne e alburno pouco diferenciados ou mesmo indistintos; quando verde o cerne apresentase levemente avermelhado, passando com o tempo para pardo amarelado brilhante ou creme; insípida e inodora; textura de média para grosseira; grã oblíqua e sinuosa. Fácil de trabalhar, podendo receber polimento um tanto atrativo. É uma madeira predisposta ao ataque de fungos e insetos.

\section{DESCRIÇÃo MACROSCÓPICA (Foto 8)}

Parênquima relativamente abundante, distinto a olho nu, predominantemente aliforme, ora apresentando aletas curtas, ora mais longas ligando e envolvendo os poros, às vezes com pequena tendência para confluente, simultaneamente vasicêntrico. Poros bem distintos sem auxílio de lente, pequenos e grandes; pouco numerosos, solitários predominantes, múltiplos de 2-3 poros, raríssimos de 4 , vazios. Linhas vasculares visíveis a simples vista, altas, retas. Raios no topo apenas notados a olho nu, relativamente abundantes, apresentando boa uniformidade na largura e espaçamento; na superfície tangencial são irregularmente dispostos, baixos e de tamanho homogêneo; no corte radial são contrastados notados mesmo sem ajuda de lente. Camadas de crescimento mal definidas. Máculas medulares e canais secretores não identificados.

\section{EMPREGOS}

Marcenaria, taboados, construção civil, caixotaria, móveis de pouco valor. O tronco da árvore serve para fabricação de remos, etc.

\section{BREU-SUCURUBA}

\section{Trattinickia rhoifolia Willd.}

BRASIL - Breu, Breu-sucuruba (Mato Grosso Aripuanã, Pará e Amazonas).

\section{ÁREA DE OCORRÊNCIA}

Desde o norte da Amazônia brasileira (Amapá e Roraima) até o sul (Mato Grosso).

\section{HABITAT}

Matas de terra firme sobre solo argiloso; habita ainda região de cerrado no Território de Roraima.

\section{CARACTERÍSTICAS GERAIS DA MADEIRA}

Madeira pouco pesada $\left(0,40-0,50 \mathrm{~g} / \mathrm{cm}^{3}\right)$; cerne pardo; textura grosseira; grã irregular; cheiro e gosto indistintos. Fácil de cortar.

\section{DESCRIÇÃo MACroscóPICA (Foto 9)}

Parênquima indistinto mesmo sob lente. Poros visíveis a olho nu, pequenos a médios, solitários com ligeira predominância, geminados e pequenas cadeias radiais; vazios. $\mathrm{Li}$ nhas vasculares visíveis a olho nu, retas, vazias. Raios no topo apenas notados a olho nu, nítidos sob lente, finos, numerosos, boa uniformidade na largura e espaçamento; na face tangencial irregularmente dispostos; na face radial pouco constrastados. Camadas de crescimento delimitadas por zonas fibrosas mais escuras.

\section{EMPREGOS}

Contraplacados, embalagens, caixotaria, rodapés, cordões, tábuas de forro, molduras, etc. 


\section{BURRA LEITEIRA}

\section{Bagassa guianensis Aubl.}

BRASIL - Burra leiteira, Tatajuba (Mato Grosso - Aripuanã). Tatajuba, Bagaceira, Amapá-rana, (Amazonas). Tatajuba, Amapá-rana, (Pará, Óbidos). G. FRANCESA - Bagasse, B. Jaune, Bois bagasse. SURINAME - Gale bagasse.

ÁREA DE OCORRÊNCIA

Comum no Aripuanã (Mato Grosso), Baixo Amazonas, Estado do Pará e Guianas.

\section{HABITAT}

Matas de terra firme.

\section{CARACterísticas gerais DA MAdeIra}

Madeira pesada $\left(0,75\right.$ a $\left.0,85 \mathrm{~g} / \mathrm{cm}^{3}\right)$; cerne amarelo queimado; às vezes com faixas mais escuras, um tanto lustroso; alburno estreito, nitidamente diferenciado do cerne; amarelo pálido, quase branco; grã irregular; textura grosseira, cheiro e gosto indistintos. Fácil de trabalhar, recebendo bom acabamento. É resistente à decomposição.

\section{DESCRIÇÃo MACROSCópiCa (Fotos 10 e 65)}

Parênquima indistinto, mesmo sob lente, confundindo-se às vezes sua cor com o conteúdo dos poros. Poros visíveis a olho nu, poucos, médios a grandes, na sua maioria solitários, geminados e algumas cadeias radiais, na sua totalidade obstruídos por tilos brilhantes da cor do lenho. Linhas vasculares distintas a olho desarmado, retas e longas contendo resina oleosa amarelada. Raios no topo visíveis à simples vista, numerosos, um tanto largos, com certa uniformidade no espaçamento e na largura; na face tangencial são curtos e irregularmente dispostos; na face radial são notados a olho desarmado. Camadas de crescimento bem demarcadas por zonas fibrosas mais escuras. Máculas medulares e canais intercelulares indeterminados.

\section{EMPREGOS}

Carpintaria, dormentes, construção civil e naval e marcenaria.

\section{CASTANHA DE COTIA}

\section{Aptandra spruceana Miers}

BRASIL - Castanha de cotia (Mato Grosso, Amazonas, Pará e Território de Rondônia). Sapucainha, Quinquió (Pará). PERU - Pmashto, Trompohuayo.

\section{ÁREA DE OCORRÊNCIA}

Ocorre na Amazônia brasileira nos Estados do Amazonas, Pará, Mato Grosso e Território de Rondônia, estendendo-se à Amazônia bolíviana e peruana.

\section{HABITAT}

Comum na mata de terra firme de solo argiloso ou arenoso e na várzea.

\section{CARACTERÍSTICAS GERAIS DA MADEIRA}

Madeira pesada $\left(0,75-0,85 \mathrm{~g} / \mathrm{cm}^{3}\right)$, de cor amarelada com tonalidade e veios acinzentados; cheiro e gosto não pronunciados; grã regular; superfície de pouco lustre; textura média para grosseira. Fácil de trabalhar; podendo receber bom acabamento com polimento um tanto atrativo.

\section{DESCRIÇÃo MACROSCóPICA (Foto 11)}

Parênquima pouco contrastado, visíve! sob lente, aparentemente difuso em finíssımas linhas irregularmente ditribuídos, descontínuas, chegando a formar com os raios uma trama fina quase contínua. Poros apenas notados à simples vista, pequenos, de pouco numerosos a numerosos, solitários, múltiplos e dispostos em longas cadeias radiais, em conjunções oblíquas, vazios e obstruídos por tilos. Linhas vasculares bem perceptiveis a olho nu, são longas, retas, contendo substância escura. Raios no topo são finos, numerosos, distribuição regular; na face tangencial são irregulares, apenas observados com auxílio de lupa, bem destacados na face radial. Camadas de crescimento pouco demarcadas por zonas fibrosas sem parênquima. Máculas medulares e canais secretores não identificados.

\section{EMPREGOS}

Brinquedos, caixas, marcenaria, construção civil e naval. 


\section{CASTANHEIRA}

\section{Bertholletia excelsa H.B.K.}

BRASIL - Castanheira, Castanha do Brasil, C. do Pará (Mato Grosso - Aripuanã). Castanha do Bra. sil, C. do Pará, C do Maranhão, Noz do Brasil, Tucary (região amazônica). GUIANA FRANCESA Taica. SURINAME - Brazilnoot, Brazilian-she noot, Ingie noto, Inginoto, Kokelero, Pará noot, Teteka, Toka, Totoka. VENEZUELA - Iubia, Iuvia, Juvia, Tucá, Turury, Ya, Yubia. COLOMBIA - Almenđro, Castanha del Maranõn, Olla de Mico. PERU - Castaño de Madre de Dios. BOLÍliA - Al. mendra del Beni, Nuez del Brasil.

Sinonímia indígena: Erai (índios Caruchi); Iniá (índios Chiprya); Tocary (índios Pareci)... Nomes comerciais estrangeiros: Nuez del Brasil (países de lingua espanhola); Noix du Brasil (França); Brazil nuts, Pará nuts, Brazil-nut tree (Inglaterra); Noce del Brasil (Itália); Paranuss (Alemanha).

\section{ÁREA DE OCORRÊNCIA}

A castanheira é uma árvore sccial encontrada em grupos (castanhais) formando grandes matas, estendendo-se desde os Estados do Maranhão e Mato Grosso até 10 de latitude através dos Estados do Pará (região de Alenquer, Almeirim e Óbidos); fronteira com o Suriname vale do rio S. João e cordilheira do Tumucumaque), e do Amazonas (vale dos rios Madeira, Maués, Purus, Negro e Solimões até o vale do Orinoco). É encontrada ainda no Peru, Guianas, Venezuela e Bolívia.

No Estado do Amazonas, ela é encontrada sobretudo nos baixos rios Solimões e Purus, médios rios Madeira e Negro, altos rios Mari-Mari e Abacaxi, e em quase todas as latitudes do Estado.

No Estado do Pará, principalmente na região do Tocantins, nos vales do Curuá e do Pará, em todos os terrenos banhados pelo rio Trombetas e seus afluentes: Cuminá, CumináMirim, Erepecuru e sobretudo no Ariramba, quer na planície, quer nos vastos campos que cobrem o planalto.

\section{HaBitat}

Principalmente mata alta de terra firme; solo argiloso ou argiloso-silicoso.

\section{Características gerais Da MAdeIRA}

Madeira moderadamente pesada $(0,70$ a $0,75 \mathrm{~g} / \mathrm{cm}^{3}$ ); cerne castanho róseo, um tanto diferenciado do alburno castanho amarelado; grã irregular para regular; textura média; cheiro e gosto indistintos. Fácil de trabalhar, recebendo acabamento esmerado; de lustre mediano.

\section{DESCRIÇÃo MACROSCóPICA (Foto 12)}

Parênquima apenas visível a olho desarmado, ou até mesmo distinto em linhas regulares, sinuosas, finas, algumas mais largas, espaçadas, formando com os raios retículo irregular. Poros visíveis a olho nu, poucos, médios a grancies, solitários, geminados e pequenas cadeias radiais, na sua maioria obstruídos por tilos brilhantes. Linhas vasculares bem notadas à simples vista contendo substância brilhante. Raios no topo são numerosos, apresentando certa uniformidade na largura e espaçamento, apenas notados a olho nu, contínuos, na face tangencial são curtos e irregularmente dispostos; na face radial são notados mesmo sem auxílio de lupa. Camadas de crescimento bem demarcadas por zonas fibrosas mais escuras sem parênquima. Máculas medulares e canais intercelulares não foram observados.

\section{EMPREGOS}

Apesar de boa madeira para forros, vigas, carpintaria, paredes, soalhos, deixa de ser aplicada na indústria madeireira em virtude de seus frutos terem maior valor comercial. Atualmente a sua exploração madeireira é proibida por lei.

\section{CEDRINHO}

\section{Cedrela fissilis Vell.}

BRASIL - Cedrinho (Mato Grosso). Cedro (Amazonas, Mato Grosso e Pará).

ÁREA DE OCORRÊNCIA

Distribuída por todo o Brasil.

\section{HABITAT}

Matas de terra firme, solo argiloso. 


\section{Características Gerais DA MADEIRA}

Madeira moderadamente pesada $(0,50-$ $0,60 \mathrm{~g} / \mathrm{cm}^{3}$ ); cerne castanho claro, rosado; grä direita a irregular; textura média; cheiro agradável; gosto indistinto. Fácil de cortar; recebe bom acabamento.

\section{DESCRIÇÃo MACROSCóPICA (Fotos 13 e 66)}

Parênquima bem visivel a olho nu, em faixas terminais, estreitas ou largas, com espaçamento irregular, tocando ou envolvendo parcialmente os poros. Poros visíveis a olho nu, poucos, médios a grandes, solitários em sua maioria, múltiplos de 2-3 poros, às vezes formando anéis semi-porosos; obstruídos por óleo-resina escura ou substância branca. Linhas vasculares bem notadas a olho nu, com óleo-resina. Raios no topo visíveis a olho nu, de distribuição regular, um tanto largos; na face tangencial visiveis sob lente, onde aparecem curtos e irregularmente dispostos; na face radial são visíveis a olho nu, pouco contrastados. Camadas de crescimento demarcadas pelo parênquima terminal e axial semi-poroso. Máculas medulares não foram observadas e canais secretores presentes em séries tangenciais.

\section{EMPREGOS}

Marcenaria, caixotaria, compensados, esquadrias, obras internas, carpintaria, caixas de charuto, tabuados, etc.

\section{CEDRORANA}

\section{Cedrelinga catenaeformis Ducke}

BRASIL - Cedrorana (Mato Grosso - Aripuanã e Amazonas - Manaus).

ÁREA DE OCORRÊNCIA

Ocorre nos Estados de Mato Grosso e do Amazonas, Manaus e Municípios de Parintins, Uaupés, São Paulo de Olivença e Tabatinga, porém mais comum no Estado do Pará e Muni- cípios próximos. Ocorre também em Yurimáguas no Peru e em Letícia (Colômbia).

\section{HaBitat}

Nos lugares úmidos e até pantanosos, com espessa camada de humus; nas matas alta de terra firme, de preferência nas nascentes e no curso superior de riachos; nas margens baixas dos igarapés em terreno argiloso.

\section{CARACTERÍsticas gerais DA MAdEIRA}

Madeira moderadamente pesada $(0,60$ a $0,70 \mathrm{~g} / \mathrm{cm}^{3}$ ); cerne vermelho roseo pouco destacado do alburno mais claro lustroso; grã direita; textura grosseira, semelhante a do cedro; cheiro desagradável quando úmida; gosto indistinto; lisa ao tato; pouco lustrosa. Fácil de trabalhar, recebendo bom acabamento.

\section{DESCRIÇÃo MACROSCÓPICA (Fotos 14 e 67)}

Parênquima pouco vasicêntrico e aliforme, de aletas curtas, visivel somente com ajuda de lupa. Poros bem visíveis a olho nu, poucos, médios a grandes, solitários predominantes, agrupados com 2-3 poros, vazios e outros contendo resina oleosa. Linhas vasculares perceptíveis à simples vista, um tanto largas, espaçadas avermelhadas. Raios no topo visíveis sob lente, muito finos, aproximados pouco destacados do fundo fibroso, na face tangencial são baixos e irregulares, na radial visíveis à simples vista. Camadas de crescimento indistintas. Máculas medulares e canais intercelulares não foram observados.

\section{EMPREgos}

Marcenaria, carpintaria, construção civil e naval, celulose e papel, móveis baratos, caixas.

\section{CEREJEIRA}

\section{Torresia acreana $\left({ }^{*}\right)$ Ducke}

BRASIL - Cerejeira, Amburana, Amburana de cheiro, Imburana (Mato Grosso e Amazonas). Cumaru de cheiro (Acre).

\footnotetext{
( *) - Torresia acreana muito se assemelha a Torresia cearensis, daí alguns considerarem como uma só espécie. Nesse caso a área de ocorrência expande-se além da Amazônia, ao Ceará até Argentina; Vale do rio Doce (Minas Gerais e Espírito Santo) e Goiás.
} 
ÁREA DE OCORRÊNCIA

Estados do Mato Grosso, Amazonas e Acre.

\section{HABITAT}

Matas de terra firme, solo argiloso.

\section{CARACTERÍSTICAS GERAIS DA MADEIRA}

Madeira moderadamente pesada $(0,60$ $\mathrm{g} / \mathrm{cm}^{3}$ ); cerne de cor bege rosado ou amarelado; textura grosseira; grã irregular; superfície áspera ao tato; exala cheiro agradável. Fácil de cortar e ser trabalhada.

\section{DESCRIÇÃo MACROSCóPICA (Fotos 15 e 68)}

Parênquima visível a olho nu, contrastado, relativamente abundante, vasicêntrico predominante e aliforme simples e confluente de aletas losangulares, o confluente chegando a formar trechos oblíquos. Poros visíveis a olho nu, médios a grandes, pouco numerosos, solitários predominantes, múltiplos de 2 freqüentes, raros múltiplos de 3 e 4 , maioria vazios, alguns obstruídos por óleo-resina escura e outros por óleo-resina mais clara que a cor do lenho bem nítidas a olho nu. Linhas vasculares visiveis a olho nu, numerosas, vazias ou obstruídas por óleo-resina. Raios no topo visíveis a olho nu, finos, poucos; na face tangencial notados a olho nu, distintos sob lente, irregularmente dispostos, com tendência a estratificação em algumas regiões; na face radial bem contrastados. Camadas de crescimento aparentemente demarcadas por zonas fibrosas mais escuras. Máculas medulares e canais secretores não foram notados.

\section{EMPREGOS}

Madeira muito requisitada para móveis finos, painéis, balcões, molduras, rodapés, esquadrias, peças torneadas, etc.

\section{COPAÍBA}

\section{Copaifera multijuga Hayne}

BRASIL - Copaíba, C. angelim, C. mari-mari, C. roxo (Estado do Amazonas).
ÁREA DE OCORRÊNCIA

Tem sido encontrada com relativa freqüência nos Estados de Mato Grosso, Amazonas, Pará e no Território de Rondônia. Possivelmenie ocorre ainda em outros locais da região amazônica.

\section{HABITAT}

Freqüente na mata alta de terra firme de preferência em solo argiloso, poucas vezes em solo arenoso.

\section{CARACTERÍsticas gerais DA MADEIRA}

Madeira pesada $\left(0,75\right.$ a $\left.0,85 \mathrm{~g} / \mathrm{cm}^{3}\right)$; cerne castanho avermelhado, bem demarcado do alburno mais claro; grã um tanto regular; textura média, análoga à do cedro; cheiro de cumarina ao cortar; sabor indistinto; de lustre um tanto sedoso e vivo.

\section{DESCRIÇÃo MACROSCópICA (Fotos 16 e 69)}

Parênquima contrastado e bem distinto sob lente nas faixas terminais afastadas, sinuosas, envolvendo pequenos canais secretores longitudinais, notando-se também predominância de paravascular. Poros apenas perceptíveis a olho desarmado, pouco numerosos, pequenos a médios, solitários predominantes, geminados e algumas cadeias radiais; vazios, alguns obstruídos por tilos. Linhas vasculares com resina oleosa da cor do lenho. Raios no topo são numerosos, finos, apresentando certa uniformidade na largura e espaçamento, apenas notados a olho nu; na face tangencial são baixos e irregularmente dispostos; na radial distinto a olho nu. Camadas de crescimento distintas, aparentemente demarcadas pelo parênquima terminal. Máculas medulares ausentes. Canais intercelulares presentes nas faixas do parênquima terminal, porém pouco distintos mesmo com auxílio de lupa.

\section{EMPREgos}

Fornece tábuas, pernamancas, ripas, etc... Boa para carvão. 


\section{CUMARU}

\section{Dipteryx odorata (Aubl.) Willd.}

BRASIL - Cumaru (Mato Grosso - Aripuanā). Cumaru, C. verdadeiro, C. roxo, Cumbari (língua geral), Cumaru da folha grande, Muirapajé (Amazonas). Cumaru (Pernambuco). GUIANA - Tonka. SURINAME - Koemaroe, Tonka. G. FRANCESA - Gaiac de cayenne, Faux gaiac. VENEZUELA c COLOMBIA - Sarrapia. PANAMÁ, COSTA RICA e HONDURAS - Ebo.

\section{ÁREA DE OCORRÊNCIA}

Freqüente em toda a mata amazônica, ocorrendo também em Mato Grosso do Sul, no Município de Corumbá. Cultivada nas Guianas e Venezuela.

\section{HABITAT}

Matas de terra firme e várzea altas do baixo Amazonas.

\section{CARACterísticas gerais DA MAdeira}

Madeira muito pesada $\left(0,95\right.$ a $\left.1,00 \mathrm{~g} / \mathrm{cm}^{3}\right)$; cerne castanho amarelo escuro, de aspecto fibroso atenuado; alburno bege claro, escasso; grã irregular; textura média; gosto indistinto; cheiro desagradável. Difícil de trabalhar, capaz de receber bom polimento. Imputrescível.

\section{DESCRIÇÃO MACROSCÓPICA (Foto 17)}

Parênquima predominante aliforme simples, pouco visível a olho nu, bem distinto sob lente e ainda vasicêntrico, às vezes confluente formando arranjos oblíquos. Poros bem visíveis com auxílio de lente, pequenos, numerosos, solitários agrupados em 2-3 poros. vazios, alguns obstruídos por tilos. Linhas vasculares um tanto altas e retas. Raios muito finos e numerosos, aproximados, bem distribuídos, visíveis somente com ajuda de lente no topo; na face tangencial apresentam-se com estratificação de 3 por $\mathrm{mm}$; na face radial são bem distintos com ajuda de lente. Camadas de crescimento pouco visíveis, demarcadas pela coloração de tecido fibroso. Máculas medulares e canais secretores ausentes.

\section{EMPREgOS}

Implementos agrícolas, dormentes. construção naval, tanoaria, ebanisteria, cabos de ferramentas, moirões, carroçaria, estacas, esteios, eixos de moinhos, tacos para soalhos, vigamentos, parquês, macetas, mancais, artigos laminados marcenaria, carpintaria, buchas de eixo de hélices de embarcações. A madeira dura de 10 a 20 anos em solos bem drenados. É tida como uma das melhores madeiras para dormentes não apenas pela durabilidade, como também porque não se fende quando exposta ao sol.

\section{CUPIÚBA}

\section{Goupia glabra Aubl.}

BRASIL - Cupiúba, Cupiúva (Mato Grosso - Aripuanã). Cupiúba (Amazonas e Pará). GUIANAS Cabacalli, Copie, Couepi Goupil, Kabukalli, Kaboekallii, Koepi, Koepie. SURINAME - Kopi, Kabukalli. VENEZUELA - Pilon.

\section{ÁREA DE OCORRÊNCIA}

Ocorre com abundância em todâ a Amazônia e ainda nas Guianas, Colômbia e Venezuela.

\section{HABITAT}

Aparece espontaneamente nas matas de terra firme tanto em solo argiloso como arenoso, e em capoeiras velhas.

\section{CARACTERÍSTICAS GERAIS DA MADEIRA}

Madeira pesada $\left(0,80\right.$ a $\left.0,90 \mathrm{~g} / \mathrm{cm}^{3}\right)$; cerne castanho amarelo ou bege claro, levemente rosado, quando recém cortado, passando com o tempo para o castanho avermelhado; não fortemente demarcado do alburno rosado ou um tanto castanho; grã regular para irregular; textura média a grosseira; gosto adstringente; cheiro desagradável de cupim, principalmente quando molhada; superfície de lustre mediano. Um tanto fácil de trabalhar, recebendo acabamento esmerado.

\section{DESCRIÇÃo MACROSCÓPICA (Fotos 18 e 69)}

Parênquima difuso, praticamente indistinto, escasso, ou ainda apenas visível sob lente, 
tendendo a formar trechos de finíssimas linhas, que se interligam formando uma trama muito fina e irregular, visível somente sob lente quando a superfície é úmida. Poros bem visíveis sem auxílio de lente, total ou parcialmente vazios, com barras de perfurações freqüentes, bem perceptíveis sob lente, pouco numerosos, médios a pequenos, solitários de grande predominância, raríssimos geminados. Linhas vasculares numerosas, altas, finas contendo resina oleosa alaranjada. Raios no topo visíveis sob lente, numerosos, finos, de distribuição regular; na face tangencial são pouco notados mesmo com auxílio de lente, baixos e irregularmente dispostos; na face radial são contrastados. Camadas de crescimento mal definidas por zonas fibrosas escuras, onde rareiam os poros. Máculas medulares e canais intercelulares não foram observados.

\section{EMPREGOS}

Dormentes, soalhos; marcenaria, móveis inferiores, caixas, caibros, carpintaria, ripas, carvão, carroceria de caminhão. Adequada ainda para construções pesadas e duráveis. É madeira de exportação.

\section{ENVIRA SURUCUCU}

\section{Bocageopsis multiflora (Mart.) R. E. Fries}

BRASIL - Envira surucucu (Mato Grosso e Amazonas). Envira preta, Envireira preta, Murteira, Envira de folha miúda (Amazonas).

ÁREA DE OCORRÊNCIA

Ocorre nos Estados de Mato Grosso, Amazonas e Acre.

\section{HaBitat}

Mata de terra firme, solo argiloso.

\section{CARACTERÍSTICAS GERAIS DA MADEIRA}

Madeira moderadamente pesada $(0,68$ $\mathrm{g} / \mathrm{cm}^{3}$ ); cerne e alburno indistintos de cor amarelado; gosto levemente amargo; odor indistinto; grã direita; textura média; levemente áspera; superfície lustrosa.

\section{DESCRIÇÃo MACROSCÓPICA (Foto 19)}

Parênquima distinto somente sob lente em numerosas linhas muito finas, aproximadas, regulares, arqueadas de raio a raio. Poros apenas notados à simples vista, de pouco a pouco numerosos, pequenos a médios, solitários predominantes, múltiplos de 2-3; vazios, alguns obstruídos. Linhas vasculares bem visíveis sem auxílio de lente, longas, largas, contendo óleo-resina da cor do lenho. Raios no topo os mais largos notados a olho nu, os mais finos visíveis sob lente, numerosos, de distribuição regular; na face tangencial visíveis sem auxílio de lente, irregularmente dispostos; na face radial bem visíveis à simp!es vista. Camadas de crescimento demarcadas por zonas fibrosas mais escuras. Máculas medulares e canais secretores não foram observados.

\section{EMPREGOS}

Caixotarias, brinquedos, caibros, andaimes, lenha, carvão, cabos de ferramentas agrícolas, etc.

\section{FAVEIRA}

\section{Vatairea guianensis: Aubl.}

BRASIL - Favercira, Angelim amargoso (Mato Grosso - Aripuanã). Faveira, Fava, Angelim amargoso (Amazonas). Faveira de empigem, Fava de bolacha, Faveira (Pará). SURINAME - Geles habbes, Geri habisi.

ÁREA DE OCORRÊNCIA

Nos Estados de Mato Grosso (Aripuanã), Pará e Amazonas desde a região do estuário, nos rios Negro, Madeira e Solimões, até a fronteira da Guiana e Venezuela, parte amazônica.

\section{HABITAT}

Freqüente nos igapós, nas margens dos rios e riachos.

\section{CARACTERÍSTICAS GERAIS DA MADEIRA}

Madeira pesada $\left(0,70\right.$ a $\left.0,80 \mathrm{~g} / \mathrm{cm}^{3}\right)$; cerne castanho amarelo-claro, tornando-se mais 
escuro em exposição ao ar; alburno esbranquiçado ou cinza; superfície lustrosa quando polida; grã um tanto regular; textura média; gosto amargo; cheiro indistinto. Fácil de trabalhar, recebendo bom acabamento.

\section{DESCRIÇÃo MACRosCópica (Fotos 20 e 71)}

Parênquima abundante, amarelado, bem visível a olho nu, contrastado, aliforme, de aletas curtas e largas, tipicamente losangular, confluente, formando pequenos trechos obliquos ou longos, e também ocasionalmente em linhas finas terminais delimitando as camadas de crescimento. Poros visíveis a olho nu, médios, alguns grandes, poucos apresentando-se solitários, geminados e pequenas cadeais radiais; vazios. Linhas vasculares bem visíveis à simples vista, largas e longas, contendo substâncias. Raios no topo finos e numerosos, apenas visíveis sem o auxílio de lente, apresentando certa uniformidade na largura e espaçamento; na face tangencial são baixos e irregularmente dispostos; na face radial são contrastados. Camadas de crescimento mal definidas. Máculas medulares e canais secretores não foram observados.

\section{EMPREGOS}

Marcenaria, carpintaria, consirução civil, caixas industriais, postes, etc.

\section{FAVEIRA DA VÁRZEA}

\section{Macrolobium angustifolium (Bth.) Cowan}

BRASIL - Fava de várzea (Mato Grosso - Aripuanã). Ipê da várzea (Pará, Curuá-Una).

ÁREA DE OCORRÊNCIA

Ocorre nos Estadios de Mato Grosso, Amazonas e Pará.

\section{HaBITAT}

Habita campinas arenosas e o igapó,

\section{Características gerais DA MAdeira}

Madeira $\Rightarrow$ moderadamente pesada $(0,65$ a $0,75 \mathrm{~g} / \mathrm{cm}^{3}$ ); cerne róseo, com o tempo passa a castanho-claro bem diferenciado do alburno de cor creme sujo biilhante; grã levemente direita; textura média a grosseira; cheiro não pronunciado; gosto adstringente. Não é fácil de ser trabalhada, podendo receber bom acabamento com lustre mediano.

\section{DESCRIÇÃo MACroscópICA (Foto 21)}

Parênquima apenas visível a olho nu, pouco contrastado, aliforme, de aletas muito curtas e vasicêntrico, de pouca confluência e em faixas ou linhas finas, afastadas, às vezes associadas e terminais. Poros perceptíveis a olho nu, poucos, pequenos a médios, solitários, múltiplos de 2-3, excepcionalmente até 4 poros; vazios, alguns obstruídos por substâncias da cor do lenho. Linhas vasculares bem perceptíveis sem auxílio de lupa, altas, retas, largas contendo no seu interior substância creme não identificada. Raios no topo são finos e numerosos, só vistos com auxílio de lente, apresentando uma boa uniformidade na largura e espaçamento; na face tangencial são curtos e irregularmente distribuídos; na radial são contrasiados e visíveis sem auxílio de lente. Camadas de crescimento levemente demarcadas por zonas escuras. Máculas medulares e canais secretores não identificados.

\section{EMPREGOS}

Marcenaria, tabuados de ótima qualidade, carpintaria, marcenaria. celulose para papel, compensados, etc.

\section{GONCQALO ALVES}

\section{Astronium fraxinifolium Schott.}

BRASIL - Gonçalo Alves, Muiracatiara, Gonçaleiro, Guaritá rajado (Mato Grosso). Gonçalo Alves, Gomável, Pau Gonçalo, Aroeira, Jejuira (Pará). GUIANA FRANCESA - Bois de zebre.

ÁREA DE OCORRÊNCIA

Ocorre nos Estados de Mato Grosso (Município de Aripuanã), Pará e Território do Amapá.

\section{HABITAT}

Matas de terra firme, solo argiloso. 


\section{Características gerais DA MAdeira}

Madeira pesada $\left(1,00 \mathrm{~g} / \mathrm{cm}^{3}\right)$, parda avermelhada com veios castanho-escuro; textura média; grã irregular; lisa ao tato; cheiro e gosto indistintos.

\section{DESCRIÇÃo MACRoscópICA (Fotos 23 e 72)}

Parênquima aparentemente ausente. Poros visíveis sob lente, pequenos, poucos, solitários e múltiplos, todos obstruídos por tilos brilhantes. Linhas vasculares um tanto irregulares, visíveis a olho nu, obstruídas. Raios no topo visíveis só com lente, finos, numerosos, bem uniformes na largura e espaçamento; na face tangencial notados a olho nu, nítidos sob lente, irregularmente dispostos; na face radial pouco contrastados. Camadas de crescimento demarcadas por zonas fibrosas mais escuras e rarefação de poros. Máculas medulares e canais secretores não foram observados.

\section{EMPREgos}

Construção civil e naval; móveis, tábuas, tornearia, tacos, etc.

\section{GUARIÚBA}

\section{Clarisia racemosa $R$. et $P$.}

BRASIL - Guariúba, G. amarela (Mato Grosso Aripuanã, Amazonas e Pará). Oiticica da mata, (Pernambuco). Oiticica (Rio de Janeiro).

Conhecida ainda por: Oiticica amarela, Oiti. Denominações estrangeiras e comerciais: Moral babo, Moral comida de mono, Sota, Zota, Capinuri, Guariúba, Tulpay.

\section{ÁREA DE OCORRÊNCIA}

Comum na região amazônica, encontrada também em Pernambuco, no sul da Bahia, vale do rio Doce e Zona da Mata, em Minas Gerais e Espírito Santo.

\section{HABITAT}

Floresta úmida das terras não inundadas ou raramente inundáveis, em solo sílico-argiloso ou argiloso.

\section{CARACTERÍSTICAS GERAis DA MADEIRA}

Madeira pesada $\left(0,60\right.$ a $\left.0,85 \mathrm{~g} / \mathrm{cm}^{3}\right)$; cerne amarelo vivo quando verde, passando com o tempo para o castanho amarelo escuro bem distinto do alburno amarelo claro; grã direita; textura média uniforme; superfície lustrosa; ligeiramente áspera ao tato; insípida e inodora; fácil de trabalhar mas requer ferramentas afiadas devido ao tipo de grã; recebendo acabamento esmerado. É de pouca duração em contato com o solo.

\section{DESCRIÇÃo MACROSCóPICA (Fotos 24 e 73)}

Parênquima abundante paravascular, bem visível a olho nu, em faixas estreitas e longas, concêntricas, contínuas, às vezes duplas, irregularmente espaçadas, ligando os poros, e também aliforme confluente formando trechos curtos oblíquos. Poros apenas perceptíveis a olho nu, poucos, pequenos a médios, alguns grandes, solitários, geminados, na sua maioria obstruídos por tilos alaranjados. Linhas vasculares são retas e longas, visíveis à simples vista, ccntendo resina oleosa alaranjada. Raios no topo visiveis a olho desarmado, apresentando certa uniformidade na largura e espaçamento; na face tangencial aparecem curtos e irregularmente dispostos; na face radial são perceptíveis a olho nu. Camadas de crescimento demarcadas por zonas fibrosas escuras sem parênquima. Máculas medulares e canais intercelulares não foram observados.

\section{EMPREGOS}

Carpintaria, construção civil e naval, cabos de ferramentas, marcenaria, tacos. Preferida pelos índios para fazer canoas, porque se trabalha com facilidade no fogo. Esta madeira, já constituiu artigo de exportação.

\section{JACAREÚBA}

\section{Calophyllum brasiliense Camb.}

BRASIL - Jacareúba (Mato Grosso - Aripuanã e Amazonas). Cedro do pântano, Guanandi-cedro, Guanandi-carvalho, Guanandi-piolho, Guanandi-rosa, Landi, Landim, Olandi, Olandim, Mangue, Jaca. 
reúba, Guanandi-landium, Olandi-carvalho, Jacareúba ou Uá-iandi. Conhecida ainda por: Aca cupia, Landium, L. do brejo, L. jacareiba, Landi, Lantim, Bálsamo jacareúba, Golandi, Guanambi, G. carvalho, G. cedro, G. leite, G. landium, G. vermelho, Guanandi, Guanantium, Gulande, Gulandi, Gulandium, G. carvalho, Inglês, Irairandira, Jacarioba, Jacurandi, Olandi, O. carvalho, Pau de azeite, P. de Sta. Maria, P. sândalo, Uaiandi, Urandi. SURINAME - Koerali of koerana. AM. CENTRAL - Galba, Palo Maria. JAMAICA - Santa Maria. PERU - Jacareuba, Lagarto-caspi. ARGENTINA - Jacareúba.

\section{ÁREA DE OCORRÊNCIA}

Das Índias Ocidentais até Santa Catarina. $\mathrm{Na}$ Amazônia é freqüente sobretudo nas várzeas e igapós. Aparece ainda na floresta atlântica e no cerrado, restinga e matas do Brasil Central.

\section{HABITAT}

Terras baixas periodicamente alagáveis e nos igapós.

\section{CARACTERÍSTICAS GERAIS DA MAdEIRA}

Madeira moderadamente pesada $(0,60$ a $0,75 \mathrm{~g} / \mathrm{cm}^{3}$ ); cerne bege rosado ou castanho ocorrendo ainda faixas de vermelho mais escuro; alburno mais claro, bem demarcado do cerne; grã irregular; textura grosseira homogênea; insípida e inodora, muito atraente, apresentando em geral, um desenho em forma de faixas, nas faces radiais da madeira serrada. Fácil de trabalhar; superfície pouco lustrosa; ligeiramente áspera ao tato. Recebe acabamento esmerado.

\section{DESCRIÇÃo MACroscóPICA (Foto 25)}

Parênquima pouco contrastado, visto somente com ajuda de lente, em faixas estreitas, sinuosas e afastadas entre si, geralmente independentes dos poros. Poros bem visíveis a olho desarmado, poucos, solitários predominantes, geminados, e em arranjos oblíquos. $\mathrm{Li}$ nhas vasculares altas, retas e com resina oleosa escura. Raios no topo são muito finos, numerosos, apresentando certa uniformidade na largura e espaçamento, visíveis somente com ajuda de lupa; na face tangencia! são notados sob lente, onde aparecem curtos e irregular- mente dispostos; na face radial são visíveis sem ajuda de lente. Camadas de crescimento mal definidas. Máculas medulares e canais intercelulares não foram observados.

\section{EMPREgOS}

Marcenaria, carpintaria, construção civil e naval, ripados, compensado, cabo de instrumentos, cutelaria, soaihos, persianas. Ótima aceitação na indústria de barris para depósito de vinho.

A madeira é muito utilizada pelas serrarias locais, sendo seu maior emprego para azimbres. Entretanto a madeira apresenta alto índice de retratibilidade volumétrica, principalmente quando exposta ao sol, causando empenamento da peça.

\section{JATOBÁ}

\section{Hymenaea courbaril L.}

BRASIL - Jatobá, Jutaí-açu, Cataquí-iamani (Ma. to Grosso - Aripuanã). Jatobá (Manaus). Jutaí, Jutaí-açu, J. grande (Pará), Jatobá (Pernambuco). Jataí, Jataizinho, Jataí-açu, Jataiba, Jataí grande, Jatai-peba, Jatai-uva, Jataí, Jatioba, Jatoba, J. de anta, J. de porco, J. roxo, J. trapuca, J. verdadeiro, Jatubá, Jataí-mondé, Jatai-uba (Bahia). Jataí (Rio de Janeiro). Em outros lugares do Brasil: Jutaí café, J. catinga, J. da várzea, J. do campo, J. do igapó, J. mirim, J. peba, J. pororoca, J. roxo, Jutaí, Jutaí branco, Óleo jutahy, Yatayba yutahy, Jatauba, Jatel, Jassaí, Jatubá, Jetaí, J. de Pernambuco, Jetaiba, Jetaibo, Jetaicí, Jetaiuba, Jetuí-peba, Jupati, Jutaí, Abatí, A. timbai, A. copal do Brasil, Árvore copal, Copal, C. americano, C. do Brasil, Ibiuva, Oleo de Jataí, Quebra machado, Trapuca, Comer de arara, Jutaí. GUIANA - Courbaril, Simiri, Locust. G. FRANCESA - Courbaril. SURINAME - Rode locus, Locus, Loksi, Lokus. COLÔMBIA Guapinal, Nazarebo. VENEZUELA - Coroboro. EQUADOR - Copal. PERU - Courbaril. A. CENTRAL - Guapinol, Cuapinol, Copinol. VIRGIN ISLAND - Locust. TRINIDAD - Stinking-toe. CUBA - Courbaril, Caguairán, Algarroba das Antilhas. JAMAICA - West Indian, Locust, Stinking-toe. INGLATERRA - Courbaril (comércio). ESPANHA - Algarroba.

\section{ÁREA DE OCORRÊNCIA}

Desde o México, atravessa a América Central, ocorrendo abundantemente na Hiléia 
chegando até S. Paulo. Aparece também nas Guianas, Suriname, Venezuela, Colômbia, Antilhas e Bolivia.

\section{HABITAT}

Matas de terra firme; freqüente em solo argiloso e em certas várzeas altas; rara no campo e nas capoeiras, onde os indivíduos tomam proporções menores.

\section{CARACTERÍsticas gerais DA MAdEIRA}

Madeira muito pesada $\left(0,80\right.$ a $\left.1,00 \mathrm{~g} / \mathrm{cm}^{3}\right)$; cerne vermelho a castanho avermelhado, apresentando às vezes manchas escuras, fortemente demarcado do alburno branco acinzentado; grã regular, ondulada ou diagonal; textura média a um tanto grosseira; cheiro e gosto indistintos; superfície pouco lustrosa. Um tanto difícil de trabalhar, recebendo acabamento agradável. Altamente durável em contato com o solo não úmido.

\section{DESCRIÇÃo MACROSCóPICA (Fotos 26 e 75)}

Parênquima bem distinto a olho desarmado, aliforme, simples e em faixas terminais típicas, largas, afastadas e às vezes associadas. Poros bem visíveis à simples vista, poucos, médios a grandes, solitários, geminados, raros de 3 poros; vazios, alguns obstruídos. Linhas vasculares visíveis sem auxílio de lupa, altas, retas, contendo substância escura. Raios no topo um tanto numerosos, apresentando uma certa uniformidade na largura e espaçamento, apenas perceptíveis a olho nu; na face tangencial são curtos, irregularmente distribuídos; na face radial são contrastados. Camadas de crescimento aparentemente demarcadas pelo parênquima terminal. Máculas medulares e canais intercelulares não foram observados.

\section{EMPREGOS}

Obras hidráulicas, carroçaria, postes, tonéis, ebanisteria, dormentes, construções de todas as espécies, móveis, laminados, esteios, tacos de soalhos, tornoaria, vigamentos, vagões, rodas e eixos de carros, bengalas, cabos de escovas e ferramentas, arcos de instrumentos musicais, estacas e construção de pianos.

\section{JENIPAPO BRAVO}

\section{Leonia glycicarpa Ruiz \& Pavon}

BRASIL - Jenipapo bravo (Mato Grosso). Farinha seca (Amazonas).

ÁREA DE OCORRÊNCIA

Ocorre nos Estados de Mato Grosso (Município de Aripuanã), Amazonas (rio Japurá, Careiro, rio Purus), Acre (Cruzeiro do Sul) e Territórios de Rondônia (rodovia Porto VelhoCuiabá e rio Madeira), Roraima (rio Mucajaí e rio Uraricoera); Bolívia (Estado de Pando).

\section{HABITAT}

Matas de terra firme em solo argiloso e/ou arenoso. Habita também a várzea.

\section{Características gerais DA MAdEIRA}

Madeira moderadamente pesada $(0,60-$ $0,70 \mathrm{~g} / \mathrm{cm}^{3}$ ), amarela, com algumas manchas acinzentadas; grã regular; textura média; um tanto áspera ao tato; cheiro e gosto indistintos. Fácil de cortar.

\section{DESCRIÇÃO MACROSCÓPIC $A$ (Foto 22)}

Parênquima aparentemente ausente. Poros visíveis só sob lente, pequenos, numerosos, solitários e múltiplos, predominando as longas cadeais radiais de até 8 poros; totalmente vazios. Linhas vasculares visiveis sob lente, retas, finas, vazias. Raios no topo visíveis a olho nu os mais largos, numerosos; na face tangencial quase invisíveis mesmo sob lente, altos, irregularmente dispostos; na face radial não contrastados. Camadas de crescimento aparentemente delimitadas por zonas fibrosas mais escuras. Máculas medulares e canais secretores não foram observados.

\section{EMPREgos}

Construção civil em geral. 


\section{JUTAI-POROROCA}

Dialium guianense (Aubl.) Sandw.

BRASIL - Jutaí-pororoca (Mato Grosso - Aripuanã). Jutaícica, Jutaí, J. pororoca, Pororoca (Amazonas). Pororoca, Jutaí, Jutaí-peba, Parajuba, Jutaí-mirim, Cururu, Itu (Pará). Sucupembinha (Maranhão). Jutaí-pororoca (Acre). Jutaí pororoca (Ter. Roraima). Jutaí (Ter. Rondônia). Pau feno (Pernambuco), Quebra machado, Deninho (Espírito Santo). SURINAME - Ironwood, Uhee-tee. COLOMMBIA - Granadillo. VENEZUELA - Cacho. PERU - Huitillo. AMERICA CENTRAL - Tamarino. MÉXICO - Guapique, Pague, Wapak. PANAMÁ - Fria, Monkey, Tamarindo de montaña. HONDURAS - Tamarino prieto, Paleto. NICARAGUA - Comenero, Slim, Tamarino montero. GUATEMALA - Paleta.

ÁREA DE OCORRÊNCIA

Ocorre com freqüência nos Estados de Mato Grosso, Amazonas, Pará, Pernambuco, Bahia, Espírito Santo, Acre, Maranhão, Territórios Federais de Rondônia, Roraima e Amapá (abundante nos rios Oiapoque e Araguari (Irwin, 1966)), Guiana, Suriname e América Central.

\section{HABITAT}

$\mathrm{Na}$ margem de certos rios e nas capoeiras de terra firme ou da várzea alta, em terrenos arenosos ou argilosos, sendo pouco freqüente na mata virgem.

\section{Características gerais DA MadeIRA}

Madeira muito pesada (peso específico de 0,90 a $1,00 \mathrm{~g} / \mathrm{cm}^{3}$ ) cerne apresentando um castanho avermelhado sujo, bem diferenciado do alburno creme; grã regular; textura média para grosseira; superfície pouco lisa ao tato, de brilho levemente acentuado, insípida e inodora. Relativamente difícil de trabalhar em virtude da grande quantidade de massas de sílica, exclusivamente no parênquima. Encontrando-se também no lenho oxalato de cálcio em pequena proporção. Recebe bom acabamento com polimento atrativo.

\section{DESCRIÇÃo MACROSCóPICA (Foto 27)}

Parênquima relativamente abundante, distinto sob lente em finas linhas regulares, apro- ximadas, às vezes interrompidas, pouco sinuosas tangenciando os poros, formando um retículo com os raios, às vezes associadas, aparentemente formando pequenas faixas apenas visiveis a olho desarmado. Poros abundantes visíveis só com ajuda de lente, solitários predominantes, múltiplos de 2-3, às vezes de 4 poros; de pouco numerosos a numerosos, pequenos, alguns médios, vazios. Linhas vasculares bem visíveis sem auxílio de lente, retas, longas, profundas, contendo resina. Raios no topo são finos e numerosos, apresentando boa uniformidade na largura e espaçamento; na face tangencial a sua estratificação (4 por $\mathrm{mm}$ ) apenas visíveis a olho nu, uniforme; na face radial notados à simples vista. Camadas de crescimento bem distintas sem auxílio de lente, demarcadas por zonas fibrosas mais escuras. Máculas medulares e canais secretores não foram observados.

\section{EMPREGOS}

Construção civil, obras hidráulicas, dormentes, vigamentos, esteios, estacas de cerca, ótima para peças de resistência.

\section{LACRE}

\section{Vochysia maxima Dur:ke}

BRASIL - Lacre (Mato Grosso - Aripuanã). Quaruba (Amazonas). Cedrorana, Quaruba verdadeira (Pará - Santarém).

\section{ÁREA DE OCORRÊNCIA}

Estado de Mato Grosso (Aripuanã) e Pará, na parte Sul do Baixo Amazonas (rio Tocantins, rio Xingu, Altamira e Santarém).

\section{HABITAT}

Comumente dispersa na mata de terra firme, limitada principalmente aos terrenos altos.

\section{CARACTERÍSTICAS GERAIS DA MADEIRA}

Madeira leve $\left(0,50\right.$ a $\left.0,55 \mathrm{~g} / \mathrm{cm}^{3}\right)$; de cor róseo claro, uniforme; grã regular; textura grosseira; cheiro e gosto indistintos; boa de trabalhar, recebendo acabamento esmerado. 


\section{DESCRIÇÃo MACROSCóPICA (Fotos 28 e 76)}

Parênquima bem visível a simples vista, contrastadc, aliforme, de extensões finas, longas, unindo vários poros, chegando a formar faixas concêntricas pouco sinuosas, afastadas irregularmente. Poros bem distintos a olho nu, grandes, solitários e agrupados em 2-3 poros; vazios, alguns obstruídos. Linhas vasculares distintas a olho nu, muito longas, altas e retas. Raios no topo visíveis a olho nu, os mais grossos, distintos sob lente os mais finos, predominantes, ambos apresentando boa uniformidade na largura e espaçamento; na face tangencial são de distribuição irregular, curtos e altos; na face radial são poucos contrastados, visíveis mesmo sem auxílio de lente. Camadas de crescimento indistintas. Máculas medulares e canais secretores não foram observados.

\section{EMPREGOS}

Caixotaria, construção de embarcações, carpintaria, indústria de compensados.

\section{LARANJEIRA}

\section{Zanthoxylum rhoifolium Lam.}

BRASIL - Laranjeira, Mamica de porco (Mato Grosso). Carne de Anta (Amazonas). Limãozinho (Amazonas e Amapá). Tamanqueira, Tamangueira da terra firme (Amazonas, Pará e Amapá). Juvevê, Espinho de vintém, Tamanqueiro, Tembetaru, Tuguaciba (Sudeste do Brasil).

ÁREA DE OCORRÊNCIA

Comum em todo o Brasil, Bolívia, Guiana Francesa e Suriname.

\section{HABITAT}

Matas primária e secundária de terra firme em solo argiloso ou argilo-silicoso.

\section{CARACTERÍsticas gerais DA MADEIRA}

Macieira leve $\left(0,40\right.$ a $\left.0,50 \mathrm{~g} / \mathrm{cm}^{3}\right)$, pardacenta com tom esverdeado, sedosa; grã regular; textura média, cheiro e gosto indistintos.

\section{DESCRIÇÃO MACROSCÓPICA (Foto 29)}

Parênquima aparentemente ausente. Poros visíveis sob lente, pequenos, numerosos, solitários e geminados, piedominando os primeiros; às vezes dispostos de maneira a formar anel semi-poroso; vazios. Linhas vasculares notadas a olho nu, finas, irregulares, vazias. Raios no topo notados a olho nu, finos, poucos; na face tangencia! quase indistintos mesmo sob lente; irregularmente dispostos; na face radial pouco contrastados. Camadas de crescimento demarcadas por zonas fibrosas mais escuras e pelo alinhamento dos poros. Máculas medulares e canais secretores não foram observados.

\section{EMPREGOS}

Usada na confecção de carroçaria, marcenaria, cabos de ferramentas, tamancos, etc.

\section{LOURO ITAÚBA}

Mezilaurus itauba (Meissn.) Taub.

BRASIL - Louro itaúba, Itaúba (Mato Grosso Aripuanã e Amazonas). Itaúba, I. amarela (Pará). Conhecida também pelos nomes: Itaúba abacate e Itaúba preta.

\section{ÁREA DE OCORRÊNCIA}

Muito comum nas cercanias de Aripuanã (Maťo Grosso), Óbidos (Pará) e no rio Tapajós. Para o Norte, alcança as Guianas; para o Oeste chega à Venezuela .

\section{HABITAT}

Encontra-se na terra firme, sempre em solos silicosos e argilo-silicosos, pobres.

\section{Características gerais Da madeira}

Madeira pesada $\left(0,70\right.$ a $\left.0,85 \mathrm{~g} / \mathrm{cm}^{3}\right)$; cerne amarelo oliva quando verde, tornando-se pardo havana em exposição ao ar, uniforme; alburno bege claro; grã regular; textura grosseira; superfície ligeiramente lustrosa; lisa ao tato; cheiro agradável quando verde; gosto picante, amargo. Fácil de trabalhar, recebe polimento muito atrativo. Não absorve umidade. 


\section{DESCRIÇÃo MACROSCóPICA (Fotos 30 e 74)}

Parênquima escasso, indistintos a olho nu, confundindo-se com o conteúdo dos poros. Poros apenas notados à simples vista, numerosos, alguns médios, na sua maioria obstruídos por tilos brilhantes da cor do lenho, solitários, geminados, em pequenas cadeias radiais ou oblíquas. Linhas vasculares apenas perceptíveis à simples vista, um tanto altas e retas, contendo resina oleosa. Raios no topo muito finos e numerosos, apresentando certa uniformidade na largura e espaçamento, notados somente com auxílio de lente; na face tangencial pouco perceptíveis mesmo com ajuda de lente, são curtos e irregularmente distribuídos; na face racilal são contrastados. Camadas de crescimento indistintas. Máculas medulares e canais secretores não foram observados.

\section{EMPREGOS}

A madeira é muito semelhante em várias de suas propriedades à "teca" (Tectona grandis), podendo substituí-la perfeitamente nas inúmeras aplicações onde a "teca" é agora altamente favorecida. É uma madeira de primeira qualidade para construção naval e civil, carpintaria, dormentes, pranchas, tabuados, tacos. Os galhos fornecem boas curvas. Resistente à ação de teredos. É madeira de exportação .

\section{LOURO SUCENA}

\section{Nectandra amazonum Nees}

BRASIL - Louro sucena (Mato Grosso). Louro, Louro do igapó, Louro da várzea, Louro amarelo do igapó (Pará e Amazonas).

ÁREA DE OCORRÊNCIA

Nos Esiados de Mato Grosso, Amazonas e Pará.

\section{HABITAT}

Comum nos igapós e várzea.

\section{CARACTERÍsticas gerais DA MAdEIRA}

Madeira pesada $\left(0,75-0,85 \mathrm{~g} / \mathrm{cm}^{3}\right)$; cerne castanho-claro brilhante, bem diferenciado do alburno amarelado; grã pouco regular; textura fina à média; superfície, lustrosa, lisa ao tato; cheiro ativo de rosa principalmente quando cortada; gosto picante bem pronunciado. Fácil de trabalhar com qualquer ferramenta, recebendo acabamento e polimento esmerado. Fende-se facilmente. Não é atacada por insetos, imputrescível.

\section{DESCRIÇÃo MACROSCóPICA (Foto 31)}

Parênquima escasso praticamente indistinto mesmo com ajuda de lupa, confundindose às vezes sua cor com o conteúdo dos poros. Poros apenas visíveis a simples vista, solitários e múltiplos de 2-3, ocasionalmente encontra-se pequenas cadeias radiais; pouco numerosos, pequenos a médios, na sua maioria obstruídos por óleo-resina da cor do lenho. Linhas vasculares bem perceptiveis a olho $\mathrm{nu}$ : são altas, retas, contendo no seu interior substância oleosa, brilhante, amarelada. Raios no topo pouco perceptíveis a olho desarmado finos e numerosos, aparentando uma certa distribuição na largura e espaçamento, contínuas. $\mathrm{Na}$ face tangencial são irregulares; na radial vistos sem ajuda de lente. Camadas de crescimento demarcadas por tecido fibroso. Máculas medulares e canais secretores não foram identificadas.

\section{EMPREGOS}

Carpintaria, marcenaria, construção em geral, especialmente naval.

\section{MAÇARANDUBA}

\section{Manilkara huberi (Ducke) Standl.}

BRASIL - Maçaranduba (Mato Grosso - Aripuanã). Maçaranduba, M. verdadeira (Pará).

\section{ÁREA DE OCORRÊNCIA}

Largamente distribuída nos Estados de Mato Grosso (Aripuanã), Pará até a metade orierilal do Amazonas e nordeste do Maranhão, (alto Pindaré) até Suriname, e das proximidades do Atlântico aos Territórios de Roraima (Serra Grande e Caracaraí), Rondônia (comum 
em Porto Velho) e Amapá (Serra do Navio). Freqüente nos arredores de Belém.

\section{HABITAT}

Nas matas de terra firme e nas várzeas pouco inundáveis.

\section{Características gerais DA Madeira}

Madeira muito pesada $\left(0,90\right.$ a $\left.1,00 \mathrm{~g} / \mathrm{cm}^{3}\right)$; cerne vermelho escuro; alburno claro; grã regular; textura média; insípido e inodoro. Fácil de trabalhar, recebe bom acabamento com lustre baixo. Resiste bem à umidade.

\section{DESCRIÇÃo MACROSCÓPICA (Fotós 33 e 77)}

Parênquima contrastado, distinto somente sob lente em finíssimas linhas, numerosas, sinuosas, aproximadas, concêntricas, às vezes interrompidas $e$ irregularmente distribuídas. Poros visíveis somente com ajuda de lente, pequenos, numerosos, alguns solitários, geminados, predominando longas cadeias radiais; na sua maioria obstruídos por tilos. Linhas vasculares são longas e retas, visíveis sem auxílio de lente. Raios no topo finos e numerosos perceptíveis com auxílio de lente, apresentando certa uniformidade na largura e espaçamento; na face tangencial são pouco notados mesmo com ajuda de lente, onde aparecem baixos e irregularmente distribuídos; na face radial são contrastados. Camadas de crescimento demarcadas por zonas fibrosas mais escuras. Máculas medulares e canais secretores ausentes.

\section{EMPREgos}

Própria para segeria, cercas, implementos agrícolas, instrumentos musicais, tacos para soalhos, torneamentos, calçamentos de ruas, dormentes, vigamentos, esteios, cavacos para cobrir casas, postes, cabos de ferramentas, estacas: resiste bem nas terras úmidas de várzeas.

\section{MAÇARANDUBA BRANCA}

\section{Virola calophyila Spr. ex Warb}

BRASIL - Maçaranduba branca (Mato Grosso Aripuanã). Ucuubarana (Pará). Ucuubarana, Ucuú- ba, Ucuúba vermelha, Ucuúba da folha grande (Amazonas).

\section{ÁREA DE OCORRÊNCIA}

No Estado de Mato Grosso (Aripuanã).

Comum nos Estados do Amazonas, Pará e Acre, presente, ainda no Território de Rondônia. Bem distribuída também no Pará, Bolívia, Colômbia, Venezuela, Equador e Guianas.

\section{HABITAT}

Florestas de terra firme; também em matas secundárias, várzea e campinas amazônicas.

\section{CARACTERÍSTICAS GERAIS DA MADEIRA}

Madeira moderadamente pesada $(0,60-$ $\left.0,67 \mathrm{~g} / \mathrm{cm}^{3}\right)$; com $12 \%$ de umidade; cerne levemente marrom quando verde, pouco diferenciado do alburno de cor mais claro brilhante, ambos com o tempo passam para um creme escuro amarelado; sem cheiro e gosto pronunciados; textura fina; grã direita. Boa de trabalhar com qualquer tipo de ferramenta, aceitando bom polimento. Casca escura, apresentando $6 \mathrm{~mm}$ de espessura, com pequenos sulcos, rugosa; látex vermelho escuro, pegajoso.

\section{DESCRIÇÃo MACroscópICA (Fotos 34 e 78)}

Parênquima pouco visíveis a simpies vista, sob lente apresenta-se em finas linhas concêntricas, afastadas, raríssimas vezes associadas, notando-se também o vasicêntrico escasso. Poros no topo apenas visíveis a olho nu, pequenos a médios, numerosos, solitários e múltiplos de 2-3, com predominância dos primeiros; vazios, raros obstruídos por tilos. Linhas vasculares são longas e retas, contendo substâncias da cor do lenho. Raios numerosos, finos, só perceptíveis com ajuda de lente, bem distribuídas; na face tangencial são irregulares; na radial bem contrastados. $\mathrm{Ca}$ madas de crescimento demarcadas por zonas de tecido fibrosos. Máculas medulares ausentes. Canais secretores ocasionalmente presentes. 


\section{EMPREGOS}

Caixas, compensados, etc..

\section{MARUPÁ}

\section{Simaruba amara Aubl.}

BRASIL - Marupá (Mato Grosso - Aripuanã). Marupá, Tamanqueira (Amazonas, Manaus). Marupá (Pará). Marupá-uba, Paraparaiba, Parariúba (Maranhão). Praiba, Paraíba, (Pernambuco e Bahia). Paraiba, Craíba (Ceará). GUIANA - Simaruba, Simarupa, Maruba. SURINAME - Soemaroepa, Walkara, Adoonsidero. COLOMBIA - Simaruba. VENEZUELA - Canuco.

Outros nomes estrangeiros e comerciais: Simarouba, Acajou blanc, Bois blanc, Bois de cayan, Bitterwood.

\section{ÁREA DE OCORRÊNCIA}

Estende-se desde as Índias Ocidentais até a Bahia, freqüente em toda a Amazônia e Estados da Bahia, Ceará e Pernambuco.

\section{HABITAT}

Mata de várzea, onde é mais freqüente e atingi maior porte, e ocasional nas capoeiras e savanas de solo arenoso.

\section{CARACTERÍSTICAS GeraIS DA MADEIRA}

Madeira terira, leve $\left(0,45\right.$ a $\left.0,55 \mathrm{~g} / \mathrm{cm}^{3}\right)$; de cor branco palha ou suja levemente amarelada ou ainda branca ligeiramente rosada, de superfície lustrosa; moderadamente lisa ao tato; grã direita; textura média a grosseira; cheiro indistinto; gosto amargo. Fácil de trabaihar, recebendo bom acabamento. Muito resisiente ao ataque de insetos.

\section{DESCRIÇÃo MACROSCóPICA (Foto 32)}

Parênquima paratraqueal, visível a olho nu, bem distinto sob lente, aliforme, com finos e longos prolongamentos laterais, lineares, às vezes unindo-se irregularmente, chegando a formar faixas sinuosas, finas associando poros, também eventualmente terminal. Poros apenas distinto a olho nu, poucos, pequenos a médios, predominante solitários geminados e pequenas cadeias radiais, vazios. Linhas vasculares são largas, longas e espaçadas. Raios no topo visiveis sob lente, numerosos; na face tangencial com uma estratificação irregular de 2 por $\mathrm{mm}$; na radial são contrastados. Camadas de crescimento indistintas. Máculas medulares não foram observadas. Canais secretores comuns, em série.

\section{EMPREgos}

Brinquedos, saltos de sapato, caixotaria, forros, fósforos, tamancos, esquadrias, marcenaria em geral, compensado, malas, pasta para papel e celulose, instrumentos musicais. Resistente aos insetos xilófagos. Pode ser usada na fabricação de pasta para papel, rendendo $44 \%$ em celulose; as fibras medem entre 0,5 e $1.2 \mathrm{~mm}$, sendo as mais freqüentes as de 08-1,0 $\mathrm{mm}$ de comprimento.

\section{MATA - MATA}

\section{Eschweilera fracta R. Knuth.}

BRASIL - Matá-matá (Mato Grosso - Aripuanã). Castanha, Castanharana, Castanha vermelha, Matá-matá, matá-matá rosa (Amazonas).

ÁREA DE OCORRÊNCIA

$$
\text { Mato Grosso (Aripuanã) e Amazonas. }
$$

\section{HABITAT}

Matas de terra firme, sobre solo argiloso, arenoso ou argilo-arenoso.

\section{Características gerais DA MAdeira}

Madeira muito pesada $\left(1,00 \mathrm{~g} / \mathrm{cm}^{3}\right)$; cerne claro pardacento ao castanho, bem diferenciado do alburno amarelado; grã pouco regular; textura média, cheiro algo desagradável quando verde; gosto indistinto. Fácil de trabaIhar, superfície pouco lustrosa, tomando acabamento com lustre mediano.

\section{DisCrição MACROSCóPICA (Foto 35)}

Parênquima abundante, visível sob lente, apenas notado a olho nu, em finas linhas sinuosas muito aproximadas, chegando a formar um retículo uniforme com os raios, interrompidos pelos poros. Poros no topo apenas perceptiveis a simples vista, poucos, peque- 
nos a médios, solitários e geminados, parcialmente obstruídos por tilos brilhantes. Linhas vasculares longas, retas. Raios visiveis sob lente, finos e numerosos, apresentando certa uniformidade na largura e espaçamento; na face tangencial são notados apenas com auxílio de lupa; na radial são destacados a olho desarmado. Camadas de crescimento demarcadas por zonas fibrosas mais escura. Máculas medulares pouco presentes. Canais secretores não foram observados.

\section{EMPREgos}

Dormentes, construção em geral, vigamentos, moiröes, cavacos para cobrir casas residenciais.

\section{MOGNO}

\section{Swietenia macrophylla King}

BRASIL - Mogno (Mato Grosso - Aripuanả). Aguano, Mogno (Amazonas). Cedrorana (Pará). Nomes comerciais e estrangeiros: Araputanga, Cedroí, Mogno - brasileiro, Caoba de Honduras, Broadleaf mahogany, Bigleaf mahogany, Central American mahogany, Caoba, Caoba Hondurenã, Chacalte, Caoba Americana, Aguano, Mahogany, Honduras mahogany, Venezuela mahogany, Peruvian mahogany, Brasilian mahogany, Acajou amerique, Mahogany Honduras, Acajou de Honduras, Mara, Caoba de hoja caduca, Orura.

\section{ÁREA DE OCORRÊNCIA}

Arvore de larga distribuição desde a península de lucatã até a Colômbia, Venezuela, Peru e extremo ocidental do Brasil.

No Brasil, sua distribuição vai das bacias superiores do Juruá e Purus, passando pela bacia do médio Madeira, Mato Grosso e sul do Pará (bacias do alto Tapajós e alto Xingu) e estendendo-se para o nordeste até o médio Tocantins e o vizinho rio Balsas (afluente do alto Parnaiba, no extremo sul do Estado do Maranhão) e terminando no médio Capim, a sudeste de Belém do Pará.

\section{HABITAT}

Abunda nas terras úmidas, algumas vezes pantånosas, porém freqüente nas ribanceiras ou ladeiras bem drenadas, que recebem alta precipitação.

\section{Características gerais DA MADEIRA}

Madeira moderadamente pesada $(0,55$ a $0,70 \mathrm{~g} / \mathrm{cm}^{3}$ ); cerne variando do castanho amarelado ao castanho escuro uniforme; alburno amarelo ou quase incolor; grã direita; textura média apresentando forte brilho nas faces longitudinais geralmente lisa ao tato; cheiro indistinto; gosto levemente amargo. Fácil de trabalhar com ferramentas manuais ou mecânicas, recebendo acabamento um tanto esmerado, devido ter uma superfície lisa e briIhante.

\section{DESCRIÇÃo MACROSCópICA (Fotos 36 e 79)}

Parênquima apenas distintos à simples vista, em faixas estreitas terminais, geralmente afastadas, nem sempre presentes. Poros visíveis a olho nu, pouco numerosos, médios, solitários, geminados, e em grupo de 3 poros; vazios e com substâncias escuras. Linhas vasculares longas e retas, contendo resina oleosa escura. Raios no topo visíveis só sob lente, apresentando certa uniformidade na largura $e$ espaçamento; na face tangencial, visiveis somente com ajuda de lente, com estratificação ( 2 por $\mathrm{mm}$ ), às vezes pouco regular; na face radia! são contrastados. Camadas de crescimento bem distintas e determinadas pelo parênquima terminal. Máculas medulares ausentes. Canais intercelulares verticais nem sempre presentes.

\section{EMPREGOS}

Por ser altamente resistente ao ataque de fungos e insetos, é usada em: móveis de luxo, compensado, construção civil, decoração interna, painéis, réguas de cálculos, objetos de adorno, artigos para escritórios, instrumentos cientificos de alta precisão, indústria de aviação e instrumentos musicais, esculturas e taIhados.

\section{MOROTOTO}

Didymopanax morototoni (Aubl.) Decne. \& Planch.

BRASIL - Morototó (Mato Grosso - Aripuanã e Amazonas). Mucututu, Matataúba, Pará-pará, Marupá-uba-falso (Pará). Sambacuim (Paraíba e Per- 
nambuco). Mandiocaí, Mandioqueira (Bahia). Pixixica (S. Paulo). G. FRANCESA - Córiovan, Bois de mai, Bois de Saint Jean. GUIANA - Karohoro, Matchwood, Morototo. SURINAME - Morototo, Cassavehout, Bigi boesie, Papajahoedoe, Kasabahoedoe, Kassavehout. PERU - Sancha-uva, Anonillo. BOLfVIA - Guitarrero. COLOMBIA Yrumero, Yagrume. VENEZUELA - Yarumo de Savana, Y. macho, Orumo macho, Sun-sun, Higuereto, Tinajero. ARGENTINA - Ambay guazu. COSTA RICA - Pava, Pavilha, Probado. PANAMÁ - Jagueme, J. macho, Pyume, Payme macho, Pava cimarróna, Grayumo, Yagrume, Y. macho, Yarumero. TRINIDAD - Match-wood, Jeretón. PORTO RICO - Pana cimarrona, Morototo, Mandioqueira (comércio). REP. DOMINICANA - Palo de sable, Sablito, Yagrumo macho. CUBA - Sapatón, Yagrumo macho, Arriero, Gavilan, Badana, Cordobán, Padero, Papayón. MEXXICO - Chancaro blanco, Robla blanco. NICARÁGUA - Costilla de danto.

\section{ÁREA DE OCORRÊNCIA}

Encontrada desde a América Central, América do Sul Tropical, da Colômbia ao Brasil (Rio de Janeiro) e Argentina.

\section{HABITAT}

F: eqüente nas matas de terra firme em solo argiloso ácido, e também em capoeiras velhas.

\section{Características gerais Da Madeira}

Niadeira moderadamente pesada $(0,55$ a $0,60 \mathrm{~g} / \mathrm{cm}^{2}$ ); lenho entrelaçado de cinzento e creme claro; grã regular; textura média; superfície lisa ao tato e lustrosa; insípida e inodora. Fácil de trabalhar, recebendo bom acabamento.

Obs.: Madeira semelhante ao "Marupá" (Si. maruba amara) e como tal é exportada.

\section{Descrição MACroscópICA (Fotos 37 e 80)}

Parênquima ausente, indistinto mesmo com auxilio de lente. Poros apenas visíveis a olho nu, pouco numerosos, pequenos, solitários, geminados, predominando estes, alguns de 3 poros, na sua maioria vazios. Linhas vasculares são longas, finas e retas, pouco realçadas, vazias. Raios no topo visíveis a olho desarmado, um tanto largos e afastados, numerosos, contínuos, às vezes interrompidos; na face tangencial são baixos e irregularmente dis- postcs, visíveis à simples vista; na face radial claramente visíveis sem auxílio de lente. Camadas de crescimento praticamente indistintas. Máculas medulares e canais secretores não foram observados.

\section{EMPREGOS}

Marcenaria, carpintaria, compensados, forros, construção em geral, esquadrias, aduelas, palitus de fósforos, caixas de embalagem, lapis, celulose e papel, com $53,20 \%$ de rendimentc.

\section{MUIRAJIBOIA}

\section{Swartzia recurva Poepp. \& Endl.}

BRASIL - Muirajiboia (Mato Grosso - Aripuanã). Muirajiboia amarela (Amazonas, Manaus). Pirauichi, Gunbeira (Pará, região do Tapajós e CuruáUna).

\section{ÁREA DE OCORRÊNCIA}

Tem larga distribuição na Amazônia brasileira, desde os Estados de Mato Grosso ao Amazonas, Pará e Território de Rondônia .

\section{HABITAT}

Típica da mata de terra firme, podendo ocorrer nas matas secundárias e margens alagáve!s dos rios.

\section{CARACTERÍSTICAS GERAIS DA MADEIRA}

Miadeira muito bonita, dura, muito pesada $\left(1,00 \mathrm{~g} / \mathrm{cm}^{3}\right)$; cerne castanho escuro e castanho arroxeado, algumas vezes o alburno se entrelaça com o cerne, produzindo desenhos curiosos; alburno propriamente dito é amarelo claro; grã regular; textura média; cheiro e gosto indistintos. Fácil de trabalhar. Recebe um bom acabamento com polimento atrativo.

\section{DESCRIÇÃo MACROSCópICA (Fotos 38 e 81)}

Parênquima reiativamente abundante, distinto a olho nu em linhas ou faixas estreitas, concêntricas, espaçadas, às vezes associadas, aliforme simples e com prolongamentos laterais extensos. Poros visíveis sob lente ou apenas notados a simples vista, pouco numerosos, 
pequenos, alguns médios ,solitários predominantes, múltiplos de 2 a 3 , raríssimos de 4 poros; vazios, alguns obstruídos. Linhas vasculares são altas e retas, obstruídas por substâncias amareladas. Raios no topo são finos e numerosos, apresentando boa uniormidade na largura e espaçamento, distintos somente com ajuda de lente; na face tangencial são estratificados, notando-se mesmo sem auxílio de lupa; na radial distintos à simples vista. Camadas de crescimento demarcadas por zonas mais escuras de tecido fibroso. Canais secretores e máculas medulares não foram observados.

\section{EMPREgos}

Tacos, construção em geral, carpintaria, marcenaria, ótima para lenha e carvão.

\section{MUIRAJUBA}

\section{Apuleia molaris Spr. ex Benth.}

BRASIL - Muirajuba, Amarelão (Mato Grosso Aripuanã). Amarelão, Muirajuba, Muirataná, Pau mulato, Muirariura (Pará). Cumarurana, Pau cetim (Acre).

\section{ÁREA DE OCORRÊNCIA}

Nos Estados de Mato Grosso, Pará e Acre.

\section{HABITAT}

Aparece nas matas de terra firme e em solo fértil de várzea alta.

\section{Características gerais DA MADEIRA}

Madeira pesada $\left(0,90 \mathrm{~g} / \mathrm{cm}^{3}\right)$; cerne pardo a pardo-acastanhado; grã regular, textura média; cheiro e gosto indistintos.

\section{DESCRIÇÃo MACROSCÓPICA (Foto 39)}

Parênquima axial indistinto a olho nu, distinto sob lente, aliforme, aletas finas, confluentes, e terminal. Poros visiveis à lupa de 10X, pequenos a médios, numerosos, solitá rios predominantes, múltiplos, alguns com resina âmarelada. Linhas vasculares numerosas, visíveis a olho nu, algumas vezes obstruídos por resina amarelada. Raios no topo distintos somente sob lente, finos, de distribuição regular; na face tangencial são pouco notados; regularmente dispostos com estratificaçăo de 3 por $\mathrm{mm}$; na face radial contrastados. Camadas de crescimento demarcadas pelo parênquima terminal.

\section{EMPREgOS}

Usada na confecção de cascos de canoas, estacas, tacos, soalhos, dormentes, caibros, vigas, ripas e cruzetas.

\section{MUIRAPINIMA}

\section{Brosimum guianensis Aubl.}

BRASIL - Muirapinima (Mato Grosso, Pará e Amazonas); Aita, Preguiceira (Pará); Quiré (Pernambuco). HONDURAS BRITANICAS - Wild, Mountain e Bastard breadnut. TRINIDAD - Leopard wood e Gatea. GUIANA - Letterwood, Gnakewood e Tibikishi. SURINAME - Letterhout. GUIANA FRANCESA - Bois de lettre e Lettre mouchette.

\section{ÁREA DE OCORRÊNCIA}

Comum na Amazônia brasileira (Mato Grosso, Amazonas, Pará, Acre e Amapá). Ainda no Brasil ocorre próximo ao Rio de Janeiro, parte de Minas Gerais e Pernambuca. No exterior aparece no Peru, Bolívia, Escudo das Guianas e Trinidad; norte da Colômbia; sudeste do Panamá e México, Hondura Britânicas.

\section{HABITAT}

Matas primárias de terra firme de solo argiloso e/ou arenoso. Habita também em capoeiras.

\section{Características gerais DA MAdeira}

Madeira moderadamente pesada $(0,60$ a $\left.0,65 \mathrm{~g} / \mathrm{cm}^{3}\right)$; de cor creme palha; grã irregular; textura grosseira; cheiro e gosto indistintos. Fácil de trabalhar.

\section{DESCRIÇÃo MACROSCóPICA (Foto 40)}

Parênquima apenas perceptíveis a olho nu, aliforme simples predominante, de aletas finas, também aliforme confluente. Poros visiveis somente com auxílio de lente, pequenos, poucos, solitários predominantes, geminados 
e em pequenas cadeias radiais; vazios. Linhas vasculares retas, longas, finas, vazias, visíveis a olho nu. Raios no topo apenas visíveis a olho nu, finos, numerosos, apresentando boa uniformidade na largura e espaçamento; na face tangencial são visíveis sob lente, irregularmente dispostos; na face radiai pouco contrastados. Camadas de crescimento demarcadas por zonas fibrosas mais escuras. Máculas medulares e canais secretores não foram observados.

\section{EMPREGOS}

Móveis, estacas, esteios, marcenaria, construções em geral.

\section{MUIRATINGA}

Maquira coreacea (Kosterm) C. C. Berg

BRASIL - Muiratinga (Mato Grosso, Amazonas e Pará).

\section{ÁREA DE OCORRÊNCIA}

Na Amazônia brasileira ocorre nos Estados de Mato Grosso (Aripuanã), Amazonas (rio Branco, lago Janauacá e Rodovia HumaitáPorto Velho), Pará (Faro, Óbidos e Almeirim); aparece também no alto rio Paraguai, Venezuela e Colômbia.

\section{HABITAT}

Matas de solo inundável periódica ou permanentemente.

\section{Características gerais DA MAdEIRA}

Madeira moderadamente pesada $(0,55$ a $\left.0,60 \mathrm{~g} / \mathrm{cm}^{3}\right)$; cerne e alburno praticamente indistintos de cor creme pardacento pouco briIhante; grã direita; textura média para grosseira; insípida e inodora. Fácil de trabalhar, recebe acabamento atrativo de lustre mediano.

\section{DESCRIÇÃO MACROSCÓPICA (Foto 41)}

Parênquima apenas visível a simples vista, tipicamente vasicêntrico. Poros perceptíveis a olho nu, relativamente abundante pequenos a médios, alguns grandes, solitários predominantes, múltiplos de 2-3, ocasionalmente de 4 poros, vazios, alguns obstruídos por tilos ou resina oleosa. Linhas vasculares longas e retas. Raios no topo bem perceptíveis a simples vista, numerosos e bem distribuídos tanto na largura como no espaçamento; na face tangencial são visíveis a simples vista e irregularmente dispostos; na face radial são contrastados perceptíveis a olho desarmado. Camadas de crescimento pouco definidas por zonas fibrosas escuras. Máculas medulares e canais secretores não foram observados

\section{EMPREGOS}

Largamente usada em compensado e laminado, caixas, etc.

\section{MUIRATINGA PRETA}

Maquira guianensis Aubl.

BRASIL - Muiratinga preta (Mato Grosso). Muiratinga (Mato Grosso, Amazonas e Pará).

ÁREA DE OCORRÊNCIA

Na Amazônia brasileira ocorre no Mato Grosso (Aripuanã), Pará (Santarém e Bragança), Território do Amapá (Serra do Navio) e Roraima. No exterior aparece na Guiana Francesa e Suriname.

\section{HABITAT}

Matas de terra firme, solo argiloso.

\section{Características gerais DA MAdeira}

Madeira pesada $\left(0,75-0,85 \mathrm{~g} / \mathrm{cm}^{3}\right)$; cerne $e$ alburno praticamente indistintos de cor creme; superfície pouco lustrosa; grã regular; textura média, lisa ao tato; gosto levemente amargo, cheiro não pronunciado. Boa de trabalhar podendo receber acabamento atrativo.

\section{DESCRIÇÃo MACrosCóPICA (Foto 42)}

Parênquima bem visível a olho nu relativamente abundante em linhas concêntricas pouco sinuosas, envolvendo ou tangenciando os pcros às vezes localmente confluente e aliforme com prolongamentos laterais curtos e 
extensos e ainda vasicêntrico. Poros só visível com auxílio de lente, pequenos, pouco numerosos, solitários predominantes, múltiplos de 2-3, excepcionalmente até 4 poros, vazios, outros obstruídos por tilos. Linhas vasculares são retas, longas, vazias, bem visíveis sem auxílio de lupa. Raios no topo finos e numerosos, apresentando uma regular uniformidade na largura e espaçamento. visto somente com ajuda de lente; na face tangencial são irregulares. na radial um tanto contrastados. Camadas de crescimento pouco distintas, às vezes demarcadas por tecido fibroso escuro. Máculas medulares e canais intercelulares, não foram observados.

\section{EMPREgOS}

Compensados, caixas, lenha, etc.

\section{MUTUTI}

\section{Ptychopetalum olacoides Benth.}

BRASIL - Mututi (Mato Grosso). Muirapuama (Amazonas, Pará e Amapá). Muirapuan, Muiratan (Pará).

ÁREA DE OCORRÊNCIA

Ocorre nos Estados de Mato Grosso (Aripuanã), Amazonas, Pará e Território do Amapá.

\section{HABITAT}

Floresta de terra firme, solo argiloso e/ou arenoso e savanas.

\section{Características gerais DA Madeira}

Madeira moderadamente pesada $(0,50-$ $\left.0,55 \mathrm{~g} / \mathrm{cm}^{3}\right)$; de cor creme, passando com o tempo para uma tonalidade mais escura, uniforme; grã direita; textura fina para média; cheiro não pronunciado; gosto um tanto desagradável. Boa de ser trabalhada mas não recebe bom acabamento com polimento atrativo em virtude do lenho apresentar em toda sua superfície uma pigmentação escura.

\section{DESCRIÇÃo MACROSCóPICA (Foto 43)}

Parênquima pouco contrastado, apenas visível a simples vista quando o topo é umide- cido, geralmente apresenta-se agregado, difuso ou em linhas finas interrompidas e irregulares formando um reticulado muito fino e indefinido. Poros no topo visíveis a olho desarmado, pouco numerosos, pequenos a médios, solitários, múltiplos de 2-3, em pequenas cadeias radiais e aparentemente agrupados ou em conjunções oblíquas; vazios e obstruídos por substância escura não identificada. Linhas vasculares são retas, visiveis a olho nu, contendo substâncias da cor do lenho. Raios no topo são apenas visíveis a olho nu os mais grossos, visiveis sob lente os mais finos. numerosos; na face tangencial são irregularmente distribuídos; na radial pouco contrastados. Camadas de crescimento pouco demarcadas por zonas fibrosas mais escuras. Máculas medulares e canais secretores não foram identificados.

\section{EMPREGOS}

Caixas, etc.

$$
\text { PARÁ - PARA }
$$

\section{Jacaranda copaia D. Don}

BRASIL - Pará-pará, Maruparana (Mato Grosso - Aripuanã). Caroba, C. manacá, Pará-pará (Manaus - Am.). Conhecida ainda como: Caraúba, Marupá falso, Caroba do Mato. G. FRANCESA Bois à Pian, Copaia, Coupaia des chanters, Faux simarouba. G. INGLESA - Fontui, Futi, Phootee. SURINAME - Goebaja, Jassie noedol.

ÁREA DE OCORRÊNCIA

Comum em toda a Amazônia.

\section{HaBitat}

Matas e capoeiras velhas de terra firme.

\section{CARACTERÍSTICAS GERAIS DA MADEIRA}

Madeira muito leve $\left(0,38\right.$ a $\left.0,40 \mathrm{~g} / \mathrm{cm}^{3}\right)$; sem distinção entre o cerne e alburno de cor branca palha levemente rosada, apresentando listras vasculares mais escuras; grã direita; textura grosseira; superfície lustrosa e lisa ao tato; cheiro e gosto indistintos. Fácil de trabalhar, podendo receber acabamento atrativo. 


\section{DESCRIÇÃo MACROSCópICA (Foto 44)}

Parênquima contrastado, aliforme simples e com prolongamentos laterais longos, às vezes unindo-se irregularmente, formando faixas finas, concêntricas, um tanto sinuosas, tocando os poros. Poros bem distintos a olho nu, poucos, médios a grandes, solitários predominantes, geminados, notando-se escassas cadeias de 3 poros; vazios. Linhas vasculares bem distintas sem auxílio de lente, são longas e retas. Raios no topo apenas perceptíveis a olho desarmado, apresentando certa uniformidade na largura; na face tangencial são baixos e irregularmente dispostos; na face radial são contrastados. Camadas de crescimento distintas ou mal demarcadas. Máculas medulares e canais intercelulares não foram observados.

\section{EMPREGOS}

Caixas, brinquedos, compensados, marcenaria, papel, palitos de fósforo, balsas; adequada para trabalho de interior.

\section{PAU D'ARCO}

Tabebuia serratifolia (G. Don) Nichols

BRASIL - Pau d'arco, Pau d'arco amarelo (Mato Grosso - Aripuanã).

ÁREA DE OCORRÊNCIA

Ocorre em todo a Amazônia, Nordeste até S. Paulo. Estendendo-se também desde as Guianas até o México.

\section{HABITAT}

Matas de terra firme e ocasional em cam. pinas amazônicas.

\section{CARACTERÍSTICAS GeRAIS DA MADEIRA}

Madeira muito pesada $\left(0,95\right.$ a $\left.1,00 \mathrm{~g} / \mathrm{cm}^{3}\right)$; cerne castanho com veios escuros; alburno amarelo rosado, um tanto diferenciado do cerne; grã regular; textura média; cheiro e gosto indistintos; de lustre baixo a médio. Um tanto difícil de trabalhar, recebendo bom acabamento com polimento atrativo. Muito durável. Incorruptivel.

\section{DESCRIÇÃo MACROSCÓPICA (Foto 45)}

Parênquima relativamente abundante, visível sob lente, predominantemente aliforme de expansões curtas, com tendência para confluente, formando com os poros pequenos arranjos obliquos, terminal em finíssimas linhas interrompidas, pouco visíveis mesmo com auxilio de lente. Poros visíveis somente com ajuda de lente, numerosos, pequenos a médios, solitários predominantes, alguns múltiplos, vazios, alguns obstruídos por tilos amarelo esverdeado. Linhas vasculares finas, longas e retas. Raios no topo visíveis com auxílio de lente, muito finos e numerosos, de espaçamento uniforme; na face tangencial ou longitudinal bem visíveis a olho nu, com uma estratificação (3 por $\mathrm{mm}$ ); na face radial são pouco contrastados. Camadas de crescimento demarcadas por zonas fibrosas escuras. Máculas medulares e canais secretores não foram observados.

\section{EMPREgos}

Marcenaria, construção civil e naval, tornos, ebanisteria, tacos de soalhos, eixos e raios de rodas.

\section{PAU MULATO}

\section{Calycophyllum acreanum Ducke}

BRASIL - Pau mulato, Mulateiro (Mato Grosso). Pau mulato da terra firme (Acre).

ÁREA DE OCORRÊNCIA

Comum no Município de Aripuanã (Mato Grosso). Aparece também no Estado do Acre e no Território de Rondônia.

\section{HABITAT}

Matas de terra firme, em solo argiloso.

\section{Características gerais Da Madeira}

Madeira pesada $\left(0,75-0,85 \mathrm{~g} / \mathrm{cm}^{3}\right)$; branco pardacento uniforme, às vezes com leves tonalidades escuras, compacta; grã regular à média; textura fina; cheiro e gosto não pronunciados; superfície levemente lustrosa. Fácil de trabalhar, podendo receber bom acabamento. 


\section{DESCRIÇÃo MACROSCóPICA (Fotos 46 e 82)}

Parênquima praticamente indistinto mesmo sob lente. Poros visíveis só sob lente, muito numerosos, pequenos, solitários, múltiplos de 2-3 e pequenas cadeias radiais, alguns em grupos formando cachos, totalmente vazios. Linhas vasculares finas, numerosas, vazias. Raios no topo visíveis com auxílio de lente, numerosos, finos, alguns mais grossos, outros associados; na face tangencial são irregularmente dispostos, na radial são contrastados. Camadas de crescimento demarcadas por zonas fibrosas escuras. Máculas medulares e canais secretores não identificados.

\section{EMPREGOS}

Caixas, construção interna, marcenaria, carvão, moirổes, esteios, estacas, tacos, etc..

\section{PAU-ROXO}

\section{Peltogyne lecointei Ducke}

BRASIL - Pau roxo, Pau roxo da terra firme (Pará). Pau roxo, Roxinho (Mato Grosso). INGLATERRA - Ruig wood.

ÁREA DE OCORRÊNCIA

Aparece espontaneamente no Pará (Óbidos e no rio Tapajós) e Mato Grosso (Município de Aripuanã).

\section{HABITAT}

Matas de terra firme.

\section{CARACTERÍSTICAS GERAIS DA MADEIRA}

Madeira pesada $\left(0,80\right.$ a $\left.0,90 \mathrm{~g} / \mathrm{cm}^{3}\right)$; cerne ao cortar, apresenta-se castanho escuro, passando com o tempo para o roxo intenso ou violeta purpúreo; grã regular; textura média; cheiro desagradável; gosto indistinto. Boa de trabalhar, resistente à decomposição.

DESCRIÇÃo MACROSCÓPICA (Fotos 47 e 83)

Parênquima aliforme predominante, confluente ou não; também terminal em linhas finas, concêntricas. Poros perceptíveis a olho nu, pequenos, numerosos, solitários predomi- nantes; vazios. Linhas vasculares finas, numerosas, vazias. Raios no topo, visíveis somente sob lente, finos, poucos; na face tangencial visíveis sob lente, irregularmente dispostos; na face radial pouco contrastados. Camadas de crescimento demarcadas por zonas fibrosas mais escuras e ausência de poros. Máculas medulares e canais secretores não foram observados.

\section{EMPREgOS}

Dormentes, postes, caibros, vigas, esteios, tacos para soalho e bilhar, vagões, carrocerias, etc..

\section{PAU-SANTO}

\section{Zollernia paraensis Huber}

BRASIL - Pau santo (Mato Grosso - Aripuanã, Pará e Pernambuco). Muirapinima preta (Pernambuco).

ÁREA DE OCORRÊNCIA

Município de Aripuanã (Mato Grosso), Estado do Pará (Estrada de Ferro de Bragança, no Tocantins e Baixo Tapajós), no noroeste do Maranhão, Paraíba e Pernambuco.

\section{HaBITAT}

Mata de terra firme, solo argiloso.

\section{CARACTERÍSTICAS GERAIS DA MADEIRA.}

Madeira muito pesada $\left(0,90\right.$ a $\left.1,00 \mathrm{~g} / \mathrm{cm}^{3}\right)$; cerne preto esverdeado com manchas mais claras; alburno amarelo claro, bem diferenciado do cerne; grã revessa; textura média; insípida e inodora. Fácil de trabalhar, recebendo polimento perfeito e atrativo. Não fornece peças grandes.

\section{DESCRIÇÃo MACROSCóPICA (Foto 48)}

Parênquima abundante, em faixas regularmente distribuidas, aproximadas, pouco onduladas, concêntricas, tangenciando os poros observa-se também curtas e finas linhas do parênquima terminal. Poros apenas notados a olho nu, pouco numerosos pequenos a muito pequenos, solitários predominantes, alguns 
geminados, geralmente obstruídos por tilos. Linhas vasculares pouco contrastadas, longas e retas. Raios no topo muito finos e numero. sos, visiveis somente com auxílio de lente, apresentando boa uniformidade na largura e espaçamento; na face tangencial vê-se uma estratificação regular ( 3 por $\mathrm{mm}$ ); na radial são contrastados. Camadas de crescimento bem demarcadas por zonas fibrosas mais escuras, sem parênquima. Máculas medulares e canais secretores ausentes.

\section{EMPREGOS}

Marcenaria de luxo, tacos, ebanisteria, carpintaria construção em geral.

\section{PEROBA}

Aspidosperma polyneuron Muell. Arg.

BRASIL - Peroba, Peroba-rosa (Mato Grosso Aripuanã). Peroba, Peroba-rosa, Peroba-amargosa, Peroba-rajada, Peroba açu, Sobro (Centro-Sul).

ÁREA DE OCORRÊNCIA

Ocorre desde o sul da Amazônia no Mato Grosso, até Bahia, Espírito Santo, Rio de Janeiro e Paraná. Fora do Brasil atinge a Peru, Argentina e Paraguai.

\section{HABITAT}

Matas de terra firme, solo argilo-arenoso.

\section{Características gerais DA Madeira}

Madeira pesada $\left(0,80-0,90 \mathrm{~g} / \mathrm{cm}^{3}\right)$; cerne róseo bege com tons vermelho-arroxeados; grã irregular; textura fina; cheiro indistinto; gosto amargoso.

\section{DESCRIÇÃo MACROSCÓPICA (Fotos 49 e 84)}

Parênquima não distinto mesmo com auxilio de lupa de 10X. Poros pequenos, visíveis com auxílio de lente, numerosos, solitários predominantes $e$ múltiplos, em parte obstruídos por óleo resina. Linhas vasculares visíveis a olho nu, finas, numerosas, em geral obstruídas por óleồ resina um pouco mais escura que a cor do lenho. Raios no topo perceptíveis a olho nu, finos, numerosos; na face tangencial pouce visiveis mesmo sob lente, irregularmente dispostos; na face radial pouco contrastados. Camadas de crescimento bem visíveis a vista desarmada, demarcada por tecido fibroso mais escuro e ausência de poros.

\section{EMPREgOS}

Esquadrias, tacos, vagões, caibros, ripas escadas, rodapés molduras, mobiliário, et..

\section{PIQUIARANA}

\section{Caryocar glabrum (Aubl.) Pers}

BRASIL - Piquiarana (Mato Grosso - Aripuanã). Piquiarana, P. vermelha (Amazonas). Piquiarana da terra (Pará). GUIANA - Cola, Bat's souari. G. FRANCESA - Saouari, Kassagnan, Agougui. SURINAME - Sawarie, Gladde sopo-ordoe of sawari, Aloekoemarirang, Sopohoedoe. VENEZUELA Jígua. COLOMBIA - Haw (Puinave), E-ko (Barasana) Kön (Kubea). PERU - Almendra, Almendro.

ÁREA DE OCORRÊNCIA

Freqüente no Município de Aripuanã (Mato Grosso), Estado do Amazonas e Pará, terras baixas do Peru, região de San Carlos; Mapiri, na Bolívia; Colômbia e na região de Cuyuni, alto Mazaruni, Demerara, rios Pomeroon e Waini, também em Potaro e Curita nas Guianas.

\section{HABITAT}

Terra firme arenosa, argilosa ou areno-argilosa e na várzea alta de solo arenoso.

\section{Características gerais DA MADEIRA}

Madeira pesada $\left(0,75\right.$ a $\left.0,90 \mathrm{~g} / \mathrm{cm}^{3}\right)$; cerne amarelo pardacento, pouco diferenciado do alburno; grã regular; textura média; cheiro, quando recém-cortado, lembra o odor de vinagre; gosto não pronunciado, superfície irregularmente lustrosa; áspera ao tato. Fácil de trabaihar.

\section{DESCRIÇÃo MACROSCÓPICA (Fotos 50 e 85)}

Parênquima contrastado, apenas notado a olho nu, geralmente difuso e em segmentos de linhas muito finas e irregulares, que em 
certos trechos chegam a formar trama um tanto irregular. Poros visiveis à simples vista, poucos, médios a grandes, solitários e geminados, algumas cadeias radiais, em sua maioria obstruídos por tilos brilhantes. Linhas vasculares visíveis a olho desarmado, espaçadas, retas e longas. Raios muito finos, numerosos, só visíveis sob lente no topo, onde aparecem com certa uniformidade; contínuos; na face tangencial são apenas notados sob lente, irregularmente dispostos e baixos; na face radial são contrastados. Camadas de crescimento demarcadas por zonas fibrosas escuras. Máculas medulares e canais intercelulares não foram observados.

\section{EMPREGOS}

Dormentes, armações de cavernas de embarcações, eixos e pinos de vagões, rodas de carro, tanoaria, marcenaria, compensado, estacas, soalho de armazens, construção civil e naval. É altamente resistente ao ataque de teredo e de grande durabilidade aos demais agentes de deterioração.

\section{RAINHA}

\section{Brosimum rubescens Taub.}

BRASIL - Rainha, Pau-rainha (Mato Grosso, Amazonas e Pará). Muirapiranga (Pará e Amazonas). GUIANA E SURINAME - Aworak. GUIANA FRANCESA - Satiné-rubané. PARANA - Blood wood cacique.

\section{ÁREA DE OCORRÊNCIA}

Ocorre na Amazônia brasileira, nos Estados de Mato Grosso, Amazonas, Pará e Território do Amapá; aparece ainda no Peru, Colômbia, Guianas e Norte do Panamá.

\section{HABITAT}

Matas de terra firme, em solo argiloso e arenoso.

\section{Características gerais DA Madeira}

Madeira pesada $\left(0,85\right.$ a $\left.1,00 \mathrm{~g} / \mathrm{cm}^{3}\right)$; cerne avermelhado brilhante com tonalidade amarelo-claro, apresentando também veios castanho escuro de aspécto fibroso. Alburno cre- me; grã de direita para pouco revêssa; textura média. Um tanto fácil de ser trabalhada; superfície lisa e lustrosa, principalmente quando polida, podendo receber bom acabamento.

DESCRIÇÃo MACroscópiCa (Fotos 51 e 86)

Parênquima contrastado apenas visível a simples vista, aliforme simples predominante de aletas curtas, finas, às vezes aparentemente confluente, ligando dois ou mais poros. Poros apenas perceptíveis a oiho desarmado, poucos, pequenos, solitários predominantes, múltiplos de 2, raríssimos de 3 , na sua maioria obstruídos por tilos ou substâncias brilhantes da cor do lenho. Linhas vasculares largas, altas, retas, bem distintas sem auxílio de lente. Raios no topo apenas visíveis sem auxilio de lente, apresentando boa uniformidade na largura e espaçamento aparentemente interrompidos (no cerne); na face tangencial são irregulares; na radial bem visiveis a olho nu. Camadas de crescimento bem demarcadas por zonas fibrosas escuras. Máculas medulares e canais secretores não foram observadas.

\section{EMPREGOS}

Tacos de soalhos, construção pesada, bengalas, instrumentos de sopro, dormentes, cabos de ferramentas, vigamentos, macetas, mancais, móveis.

\section{SANGUE DE BOI}

\section{Iryanthera juruensis Warb.}

BRASIL - Sangue de boi, Ucuubarana (Mato Grosso). Uchi vermelho, Ucuúba, Ucuubarana, UcuúbaPunã (Amazonas). PERU - Cumala, Cumalilla, Cumalita, Cumala blanca, Cumala bolabola, Cumala roja.

\section{ÁREA DE OCORRÊNCIA}

Largamente distribuída por toda a Amazônia brasileira, no Estado do Pará (Santarém e Monte Dourado, Óbidos e Serra de Parintins), Mato Grosso (Aripuanã), Amazonas (Tefé, rio Cuieiras, rio Javari, Estrada Manaus-Porto Velho, Boca do Acre, etc.), Acre (Tarauacá-e Sena Madureira) e Territórios de Rondônia (Guajará-Mirim) e Roraima (Serra dos Surucucus). Aparece ainda no Peru e Venezuela. 
HABITAT

Matas de terra firme, em solo arenoso e argiloso.

\section{CARACTERÍSTICAS GERAIS DA MADEIRA}

Madeira relativamente pesada $(0,65$ a 0,75 $\left.\mathrm{g} / \mathrm{cm}^{3}\right)$; cerne vermelho escuro; alburno begerosado; grã direita e irregular; textura média; cheiro e gosto indistintos.

\section{DESCRIÇÃO MACROSCÓPICA (Foto 52)}

Parênquima relativamente abundante, terminal em faixas finas, irregularmente afastadas, porém numerosas, chegando a formar uma leve trama fina com os raios, vazios ou com óleo resina escuro. Poros visíveis somente com auxílio de lente, pequenos, pouco numerosos; predominando os múltiplos de 2; múltiplos de 3 e 4 menos frequentes; solitários raros. Linhas vasculares finas, numerosas, pouco visiveis a olho nu. Raios no topo finos, numerosos, visíveis somente com lente; na face tangencial pouco distintos mesmo com auxílio de lente; irregularmente dispostos; na face radial pouco contrastados. Camadas de crescimento aparentemente demarcada pelas faixas de parênquima terminal.

\section{EMPREgos}

Molduras, sarrafos, ripas, compensados, contraplacados, caixas, etc.

\section{SUCUPIRA PRETA}

\section{Cassia adiantifolia Benth.}

BRASIL - Sucupira preta (Mato Grosso - Aripuanã e Amazonas). Muira paxiúba, Coração de $\mathrm{Ne}$ gro, Pau preto (Pará).

ÁREA DE OCORRÊNCIA

Mato Grosso (Aripuanã), Pará (Breves) e Amazonas.

HABITAT :

Matas de terra firme, sobre terreno argiloarenoso, arenoso e pantanosos.
CARACterísticas gerais DA MAdeIra

Madeira muito pesada $\left(0,95-1,00 \mathrm{~g} / \mathrm{cm}^{3}\right)$; cerne castanho escuro quase preto; alburno escasso, bem destacacio por apresentar uma cor pardo avermelhado; grã um tanto irregular; textura grosseira, áspera ao tato de aspecto fibroso bastante atenuado; gosto levemente amargo; cheiro indistinto. Difícil de ser trabalhada, recebe polimento atrativo. Muito resistente. Imputrescível (cerne).

\section{DESCRIÇÃo MACrosCópICA (Foto 53)}

Parênquima relativamente abundante perceptíveis a simples vista no cerne, bem visível a olho nu no alburno, aliforme de aletas curtas, confluente, resultando a formação de trechos longos, largos, curtos e irregulares, às vezes com tendência para pequenas faixas concêntricas. Poros apenas observados a simples vista, médios a grandes, alguns pequenos; poucos, solitários predominantes, geminados de 2-3, eventualmente em pequenas cadeias radiais; vazios e obstruídos por tilos. Linhas vasculares bem destacadas sem auxílio de lente, são longas e retas, totalmente obstruídas por substância escura da cor do lenho. Raios no topo só visíveis com ajuda de lupa, na face tangencial são irregularmente dispostos, na radial são contrastados. Camadas de crescimento apenas demarcadas por zonas fibrosas escuras. Máculas medulares e canais secretores inaparentes.

\section{EMPREGOS}

Tacos, dormentes, construção civil e naval, marcenaria, etc.

\section{SUCUPIRA PRETA}

Bowdichia nitida Spr. ex Benth.

BRASIL - Sucupira preta, Sucupira, Sucupira da terra firme (Mato Grosso e Amazonas). Sapupira, Sapupira da mata (Pará).

ÁREA DE OCORRÊNCIA

Ccorre nos Estados de Mato Grosso, Amazonas, Pará e Território de Rondônia. 


\section{HABITAT}

Matas de terra firme, solo argiloso e/ou arencso.

\section{CARACTERÍSTICAS GERAIS DA MADEIRA}

Madeira pesada $\left(0,90 \mathrm{~g} / \mathrm{cm}^{3}\right)$; cerne castanho-escuro com tom amarelado; grã revessa; textura grosseira; cheiro e gosto indistin. tos. Madeira dura, difícil de trabalhar.

\section{DESCRIÇÃo MACROSCóPICA (Foto 54)}

Parênquima visível a olho nu, muito contrastado, vasicêntrico, aliforme simples e confluente, chegando a formar pequenos arranjos oblíquos, e em linhas terminais finas, irregulares. Poros visíveis a olho nu, médios a granđes, poucos, solitários, múltiplos de 2,3 e cadeias radiais de até 5 poros, vazios. $\mathrm{Li}$ nhas vasculares visiveis a olho nu, numerosas, vazias, retas. Raios no topo apenas perceptiveis a olho nu, finos, poucos; na face tangencial visíveis só sob lente, estratificados, 3 camadas de estratificação por $\mathrm{mm}$; na face radial contrastados. Camadas de crescimenio aparentemente delimitadas pelo parênquima terminal. Máculas medulares e canais secretores não foram notados.

\section{EMPREGOS}

Construção civil e naval, postes, moirões, estacas, dormentes, cruzetas, laminados, tacos, móveis, elevadores, tábuas de assoaIho, etc.

\section{TABINHEIRO}

\section{Erisma uncinatum Warm.}

BRASIL - Tabinheiro (Mato Grosso - Aripuanã). Quarubarana (Pará, Santarém). Bruto (Maranhão). Conhecida ainda por: Jaboti, J. da terra firme, Quariuba, Quarubatinga, Quaruba vermelha, Q. de flores roxas. GUIANA - Pramaye. SURINAME Singri, Kwanie.

\section{ÁREA DE OCORRÊNCIA}

Ocorre com maior freqüência nos Estados de Mato Grosso e Pará (Santarém, CuruáUna). Tendo sido também reconhecida nos Territórios de Roraima e Amapá; Guiana e Suriname.

\section{HABITAT}

Mata de terra firme, de solo argiloso; em Roraima sobre solo laterítico na base de elevações montanhosas.

\section{CARACTERÍSTICAS GERAIS DA MADEIRA}

Madeira moderadamente pesada $(0,60$ $\mathrm{g} / \mathrm{cm}^{3}$ ); cerne róseo-acastanhado, às vezes, com manchas irregulares esparsas; superfície pouco lustrosa; alburno branco amarelado, bem distinto do cerne; textura grosseira; grã direita ou ondulada; cheiro e gosto indistintos.

\section{DESCRIÇÃo MACROSCÓPICA (Fotos 55 e 87)}

Parênquima distinto a olho nu, em faixas tangenciando os poros, aproximados, ondulados, largas, longas, e também em trechos curtos, descontínuos, isolados. Poros distintos a olho nu, grandes e médios, múltiplos e solitários, poucos, obstruídos por tilos. Linhas vasculaires distintas, longas, infiltradas de tilos. Raios visíveis somente com lente no topo e na face tangencial, dispcstos irregularmente e espaçados na radial. Camadas de crescimento praticamente indistintas. Máculas medulares e canais secretores não foram observados.

\section{EMPREGOS}

Tabuados e construção em geral, caixotaria, carpintaria comum. Muito resistente. Na regiấo de Aripıanã os cavacos săo usados para cobertura de residências.

\section{TACHI}

\section{Tachigalia paniculata Aubl.}

BRASIL - Tachi (Mato Grosso, Amazonas e Pará). Tachi preto (Amazonas). Tachi branco (Pará). Louro tachi (Maranhão). GUIANA FRANCESA - Tachigali. SURINAME - Adsdoe, Gedoe.

\section{ÁREA DE OCORRÊNCIA}

Estado de Mato Grosso (Aripuanã); Estado do Pará (rio Tapajós-Bela Vista; rio XinguAltamira; rio Tocantins-Alcobaça; Peixe-Boi; Estrada Belém-Bragança; rió Acará); Guiana Francesa e Suriname. 


\section{HABITAT}

Comum nas várzeas e igapós dos rios de água pobre em sedimento, menos freqüente na mata e no capoeirão de terra firme, argilosa, numa forma ligeiramente diferente.

\section{CARACTERÍsticas gerais DA MAdEIRA}

Madeira moderadamente pesada $(0,65$ a $\left.0,70 \mathrm{~g} / \mathrm{cm}^{3}\right)$; cerne castanho, não fortemente diferenciado do alburno amarelo, claro, briIhante, com listas escuras distintas; cheiro desagradável quando verde; gosto indistinto; textura média; grã regular. Fácil de trabalhar, recebendo bom acabamento.

\section{DESCRIÇÃo MACROSCóPICA (Foto 56)}

Parênquima notado a olho nu, nítido sob lente, contrastado, predominante aliforme simples de aletas curtas e vasicêntrico. Poros apenas visíveis a olho nu, poucos, pequenos a médios, solitários predominantes, geminados e em pequenas cadeias radiais; vazios. Linhas vasculares altas e um tanto largas, distintas à simples vista. Raios no topo visíveis sob lente, finos e numerosos, com certa uniformidade na largura e espaçamento; na face tangcncial são muito baixos, irregularmente dispcstos, pouco distintos mesmo com auxílio de lente; na face radial são contrastados. Camadas de crescimento bem distintas sem auxílio de lente e demarcadas por zonas fibrosas escuras. Máculas medulares e canais secretores não foram observados.

\section{EMPREGOS}

Construção em geral.

\section{TAQUARI}

\section{Miconia poeppigii Trian.}

BRASIL - Taquari (Mato Grosso - Aripuanã).

ÁREA DF OCORRÊNCIA

Ocorre na Amazônia brasileira nos Estados de Mato Grosso (Aripuanã), Amazonas (rio Purus) "e Território de Rondônia (GuajaráMirim). Aparece também na Bolívia (Estado de Pando).

\section{HaBitaT}

Matas de terra firme, solo argiloso.

CARACTERÍsticas gerais DA MADEIRA

Madeira moderadamente pesada $(0,60$ $0,70 \mathrm{~g} / \mathrm{cm}^{3}$ ); castanho-amarelada; grã regular; textura média; cheiro e gosto indistintos; superfície brilhosa.

\section{DESCRIÇÃo MACROSCÓPICA (Foto 57)}

Parênquima nítido só sob lente, em faixas largas, interrompidas, irregulares, quase sem. pre envolvendo os poros. Poros visíveis a olho nu, pequenos a médios ,poros solitários e múltiplos, predominando os primeiros. Linhas vasculares visíveis a olho nu, retas, vazias. Raios no topo visiveis só sob lente, numerosos, finos; na face tangencial irregularmente dispostos; na face radial contrastados. Camadas de crescimento demarcadas por zonas fibrosas mais escuras e rarefação de poros. Máculas medulares e canais secretores não foram observados.

\section{EMPREgOS}

Construção em geral.

\section{TENTO}

\section{Ormosia paraensis Ducke}

BRASIL - Tento (Mato Grosso - Aripuanã). Tento, Molongu da mata (Amazonas).

ÁREA DE OCORRÊNCIA

Mato Grosso, Pará e Amazonas.

\section{HabItat}

Matas de terra firme.

\section{CARACTERÍsticas gerais DA MAdEIRA}

Madeira pesada $\left(0,75-0,80 \mathrm{~g} / \mathrm{cm}^{3}\right)$; cerne alaranjado pálido bem diferenciado do alburno de cor cinza com reflexos creme; textura grosseira; grã levemente irregular; gosto amargo, cheiro não pronunciado; superfície pouco lustrosa. Um tanto difícil de ser trabaIhada, 


\section{DESCRIÇÃo MACROSCóPICA (Foto 58)}

Parênquima axial abundante, muito contrastado, perfeitamente visível a olho nu, do tipo paratraqueal, aliforme confluente predominante, de aletas largas, chegando a formar trechos obliquos unindo vários poros, também aliforme simples. Poros perfeitamente visíveis a olho nu, pequenos a muito grandes, de pouco a pouco numerosos; solitários predominantes, múltiplos de 2-3, raros de 4 ; vazios ou ocasionalmente obstruídos por substâncias semelhante a goma. Linhas vasculares visiveis a olho nu nas secções longitudinais, retas, às vezes contendo substâncias da cor do lenho. Raios visiveis a olho nu, apresentando uniformidade regular na largura e espaçamento; na secçâo tangencial perceptíveis a olho nu, irregularmente dispostos, porém apresentando vários campos de estratificação, esta de 3 a 4 listras por $\mathrm{mm}$, na secção radial pouco contrastados, visíveis a olho nu. Camadas de crescimento indistintas. Máculas medulares e canais secretores não foram observados.

\section{EMPREgos}

Caixas de embalagens, etc..

\section{UCUÚBA}

Virola elongata (Benth.) Warb.

BRASIL - Ucuúba (Mato Grosso - Aripuanã). Ucuúba branca, Ucuúba preta, Ucuúba vermelha, Ucuubinha, Uiqui (Amazonas). Mimba-branca (Pará).

\section{ÁREA DE OCORRÊNCIA}

Largamente distribuída na Amazônia geográfica.

\section{HABITAT}

Matas alagáveis nas margens de rios e lagos, campos e encostas da terra firme.

\section{Características gerais DA MAdeIRA}

Madeira moderadamente pesada $(0,62$ $\left.\mathrm{g} / \mathrm{cm}^{3}\right)$, com $11.7 \%$ de umidade; cerne e alburno creme uniforme a castanho acinzentado claro, com o decorrer do tempo passa ou tor- na-se de certo modo mais escuro brilhante; sem cheiro e gosto pronunciados; textura tina; grã levemente ondulada. Relativamente fácil de ser trabalhada, porém, aceita excelente polimento. Casca fina, em média $2 \mathrm{~mm}$ de espessura, marrom, rugosa, fissurada, com escassa resina avermelhada.

\section{DESCRIÇÃo MACROSCÓPICA (Foto 59)}

Parênquima extremamente escasso, indistinto mesmo sob lente. Poros visíveis a simples vista, pouco numerosos a numerosos, solitários e múltiplos de 2 predominantes, alguns de 3 poros, ocasionalmente encontra-se pequerios grupos; vazios, raros obstruídos por tilos ou substâncias gomosas. Linhas vasculares retas, finas e grosseiras, distintas a olho nu, na sua totalidade contém substância escura. Raios no topo pouco perceptíveis sem auxílio de lente, um tanto numerosos, finos e outros associados; na face tangencial são altos e baixos com predominância dos primeiros, irregularmente dispostos; na radial bem destacados devido sua cor creme contrastando com o tecido lenhoso escuro brilhoso. Camadas de crescimento, ausentes. Máculas medulares e canais secretores não identificados.

\section{EMPREGOS}

Marcenaria, caixas e compensados, etc..

\section{UCUÚBA}

\section{Virola pavonis (A. DC.) Smith}

BRASIL - Ucuúba (Mato Grosso - Aripuanã). Ucuúba, Ucuhuba, Ucuúba branca do baixio (Amazonas).

\section{ÁREA DE OCORRÊNCIA}

$\mathrm{Na}$ Amazônia brasileira ocorre nos Estados do Mato Grosso e Amazonas; Território de Rondônia. Fora do Brasil ocorre no Peru, Colômbia e Venezuela.

\section{HABITAT}

Matas de terra firme, ocasional nas pseudo-caatingas de solo arenoso, raro em mata pantanosa. 


\section{CARACTERÍSTICAS GERAIS DA MADEIRA}

Madeira moderadamente pesada $(0,70$ $\left.9 / \mathrm{cm}^{3}\right)$; com $11-12 \%$ de umidade; cerne e alburno praticamente indistintos, de cor creme claro brilhante; textura média; superfície lustrosa; grã direita; cheiro e gosto não pronunciadcs. Fácil de ser trabaihada com qualquer tipo de ferramenta. Casca com 4-5 mm de espessura, rajada, latex amarelado ao cortar, em exposição ao ar passa para o vermelho escuro.

\section{DESCRIÇÃo MACROSCóPICA (Foto 60)}

Parênquima relativamente escasso, vasicêntrico, bem visível sob lente as finas linhas concêntricas, afastadas, raras vezes associadas. Poros apenas perceptíveis a olho nu, pequenos, de pouco a pouco numerosos; vazios alguns obstruídos por tilos brilhantes; maioria solitários, múltiplos de 2-3, raros de 4-5, esporadicamente aparece em grupo de 3-4 elementos. Linhas vasculares são longas, retas, contendo substância avermelhada. Raios no topo visíveis a olho nu, numerosos, apresentam bca distribuição na largura e espaçamento; na face tangencial são irregulares, na radial visíveis a olho nu. Camadas de crescimento perceptíveis sem auxílio de lente e bem demarcadas por zonas de tecido fibroso. Máculas medulares e canais secretores não foram observados.

\section{EMPREGOS}

Caixas compensados, laminados, tábuas, etc. .

\section{UCUUBARANA}

Iryanthera laevis Markg.

BRASIL - Ucuúba, Ucuubarana (Mato Grosso e Amazonas). Lacre da mata virgem, Ucuúba-punã, Ucuúba vermelha, Ucuúba da terra firme (Amazonas).

\section{ÁREA DE OCORRÊNCIA}

Comum na Amazônia brasileira, nos Estados do Amâzonas e Mato Grosso e Territórios de Rondônia e Roraima. Aparece também no Peru (Loreto).

\section{Habitat}

Matas de terra firme sobre solo argiloso e arenoso.

\section{CARACTERÍSTICAS GERAIS DA MADEIRA}

Madeira moderadamente pesada $\quad(0,60$ a $0,70 \mathrm{~g} / \mathrm{cm}^{3}$ ); cerne vermelho escuro, alburno róseo-claro a amarelado, cheiro e gosto indistintos; atacada por insetos; textura média; grã regular. Alburno.

\section{DESCRIÇÃo MACROSCópICA (Foto 61)}

Parênquima relativamente abundante, visível a olho nu, em linhas concêntricas, nítidas, finas e quase sempre espaçadas regularmente. Poros visíveis a olho nu, pequenos a médios, poucos numerosos; solitários e múltiplos de 2,3-4 destes predominando os geminados; vazios. Linhas vasculares freqüentes, finas. Raios no topo apenas perceptiveis a olho nu, numerosos, finos; na face tangencial pouco visíveis mesmo sob lente, irregularmente dispostos; na face radial contrastados. Camadas de crescimento aparentemente não visíveis. Máculas medulares e canais secretores não foram observados.

\section{EMPREGOS}

Molduras, sarrafos, ripas, compensados, contraplacados, etc..

\section{UCUUBARANA}

\section{Iryanthera paraensis Huber}

BRASIL - Ucuubarana, Ucuúba (Mato Grosso e Amazonas). Ucuúba vermelha (Amazonas e Pará). PERU - Varilla cumalla.

ÁREA DE OCORRÊNCIA

$\mathrm{Na}$ Amazônia brasileira esta bem difundida nos Estados do Mato Grosso (Município de Aripuanã), Amazonas (rio Solimões; Fonte Boa; rio Javari; Estrada Manaus-Porto Velho entre Castanho e Tupana; rio Purus), Pará (rio Trombetas na Cachoeira Porteira), Acre (Cruzeiro do Sul) e Territórios de Roraima (Uaicá, Serra da Lua e Serra Tapequém) e Rondônia (arredores de Porto Velho). Estende-se ao Suriname e Peru. 


\section{HABITAT}

Mata de terra firme, solo argiloso.

\section{Características gerais DA MADEIRA}

Madeira relativamente pesada $(0,60-$ $\left.0,70 \mathrm{~g} / \mathrm{cm}^{3}\right)$; cerne vermelho escuro contrastado com o alburno bege-rosado; grã direita; textura média; cheiro e gosto não pronunciados.

\section{DESCRIÇÃo MACROSCópICA (Foto 62)}

Parênquima pouco contrastado, visível a olho nu, terminal em faixas nítidas, concêntricas, finas e irregularmente espaçadas. Poros apenas perceptíveis a olho nu, pequenos, pouco numerosos, predominando os geminados solitários e múltiplos de 3 e 4 raros; vazios, alguns contendo óleo resina escura. Linhas vasculares numerosas, finas, pouco contrastadas. Raios no topo visiveis somente sob lente, finos e numerosos; na face tangencial quase indistintos mesmo sob lente; irregularmente dispostos; contrastados na face radial. Camadas de crescimento aparentemente demarcadas pelo parênquima concêntrico. Máculas e canais secretores nảo foram identificados.

\section{EMPREGOS}

Compensados e contraplacados.

\section{UCUUBARANA}

$$
\text { Iryanthera ulei Warb. }
$$

BRASIL - Ucuubarana (Mato Grosso, Amazonas, Pará, Acre e Território de Rondônia). PERU Ulipa-cumalla.
ÁREA DE OCORRÊNCIA

Comum praticamente em toda a Amazônia brasileira. Aparece também no Peru, Colômbia e Bolivia.

\section{HABITAT}

Matas de terra firme, solo argiloso.

\section{CARACTERÍSTICAS GERAIS DA MADEIRA}

Madeira moderadamente pesada $10,60-$ $\left.0,70 \mathrm{~g} / \mathrm{cm}^{3}\right)$; cerne avermelhado; alburno begerosáceo; grã regular; textura média levemente áspera.

\section{DESCRIÇÃo MACROSCóPICA (Foto 63)}

Parênquima perceptível a olho nu, em faixas nítidas, finas e irregularmente espaçadas. Poros visíveis a olho nu, pequenos a médios, pouco numerosos, múltiplos de 2 predominantes, solitários, múltiplos de 3 e 4 também presentes; vazios, raro obstruidos. Linhas vasculares numerosas, finas, algumas com conteúdo óleo-resinoso. Raios no topo nítidos só sob lente, finos, numerosos; na face tangencial pouco visíveis sob lente, irregularmente dispostos; contrastados na fecs radial. Camadas de crescimento aparentemento demarcadas por tecido fibroso mais escuro. Máculas medulares e canais secretores não foram observados.

\section{EMPREGos}

Caixotaria, compensados, contraplacados, sarrafos, ripas, etc.. 
Page in blank 
TABELA DAS CARACTERISTICAS FISICAS E MECÂNICAS DE ALGUMAS ESPÉCIES 
Page in blank 


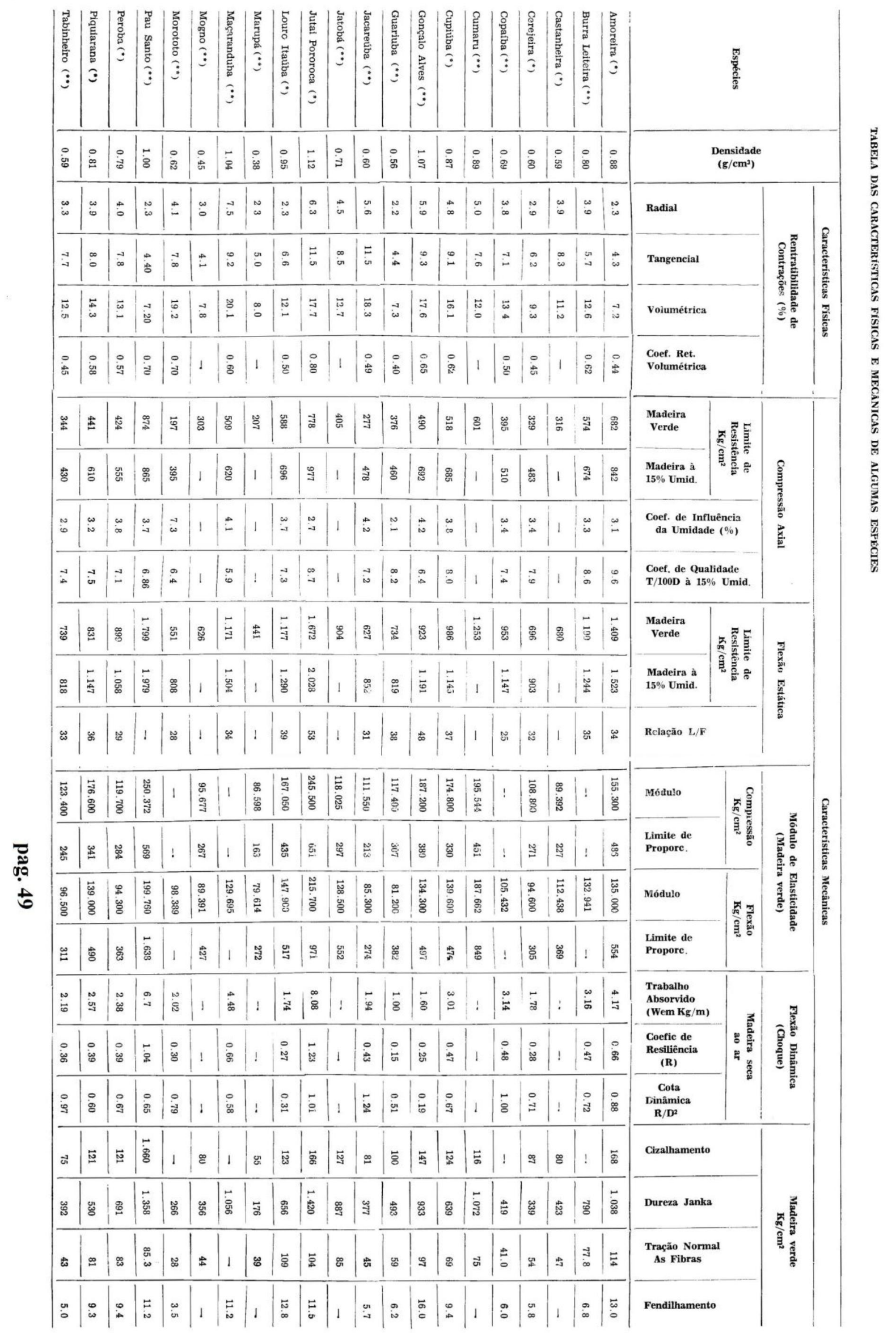


ATLAS DAS MACROFOTOGRAFIAS DAS SECÇÕES TRANSVERSAIS DAS ESPÉCIES 


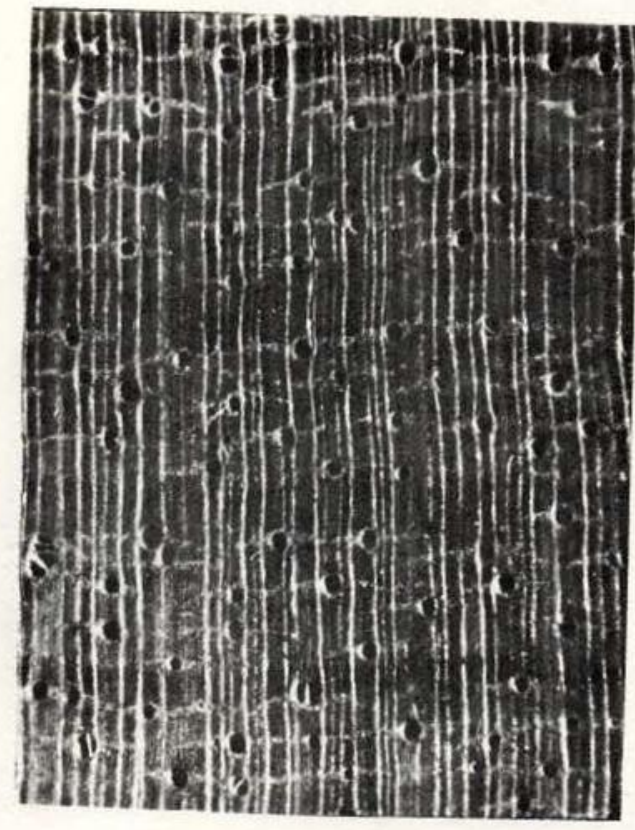

Foto 1 - Brosimum utile

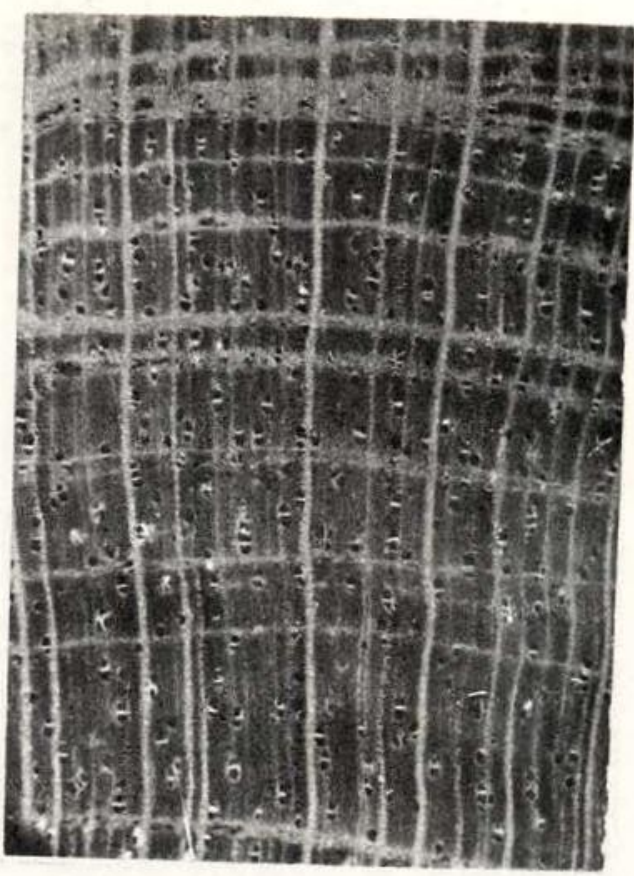

Foto 2 - Zanthoxylum sp.
AMEIXA

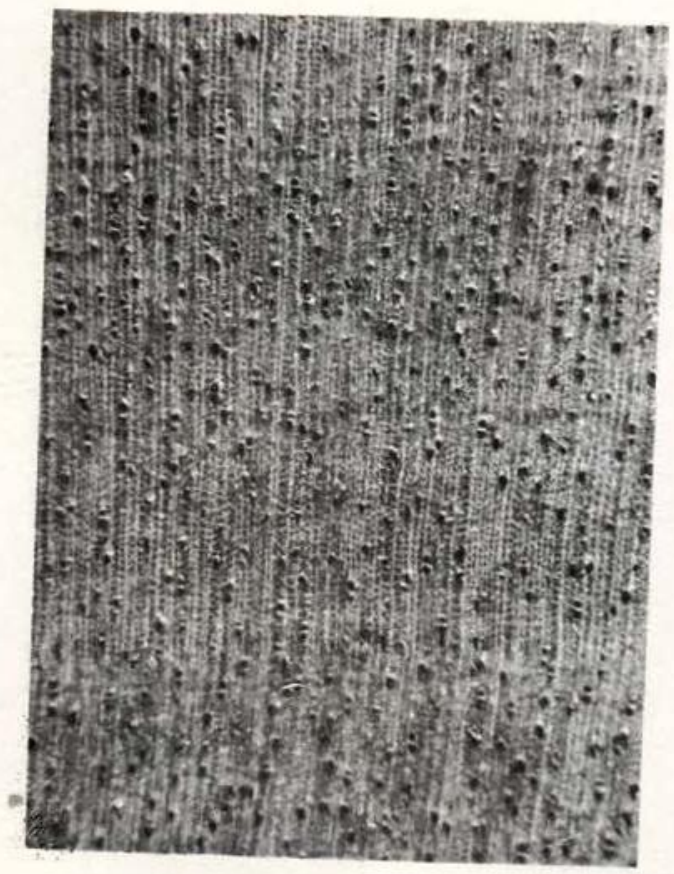

Foto 3 - Drypetes variabilis
AMOREIRA

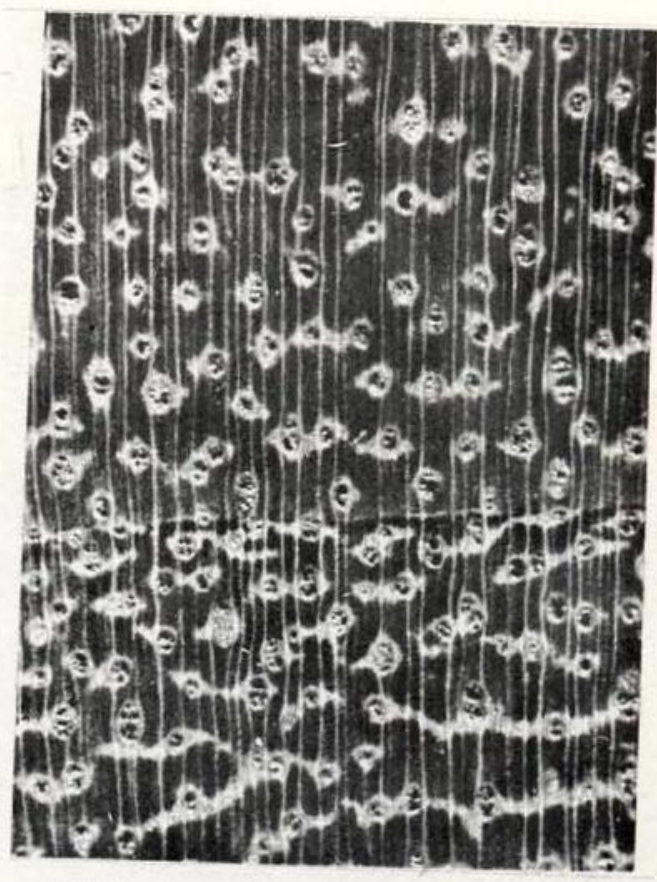

Foto 4 - Chlorophora tinctoria 


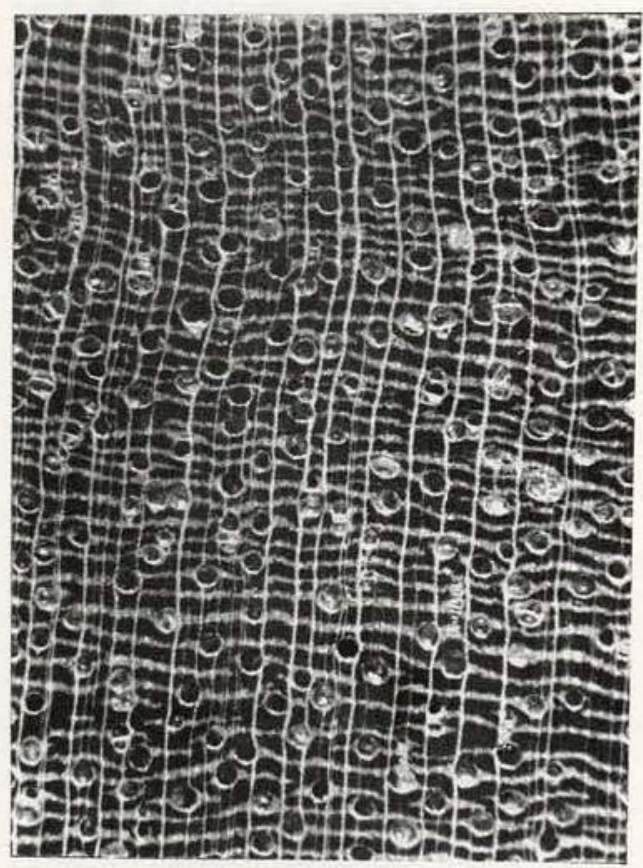

Foto 5 - Symphonia globulifera

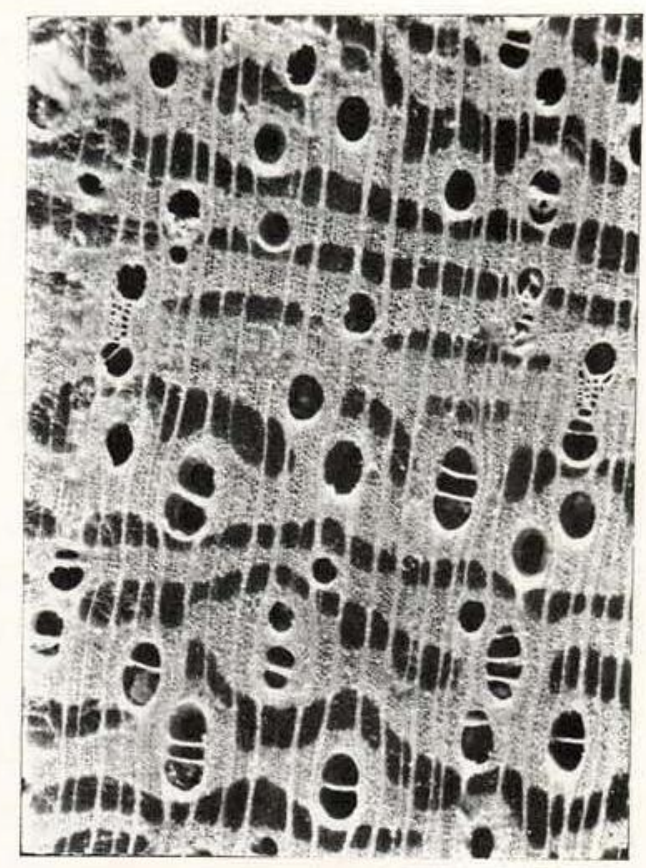

Foto 6 - Hymenolobium petraeum
ARAPARI

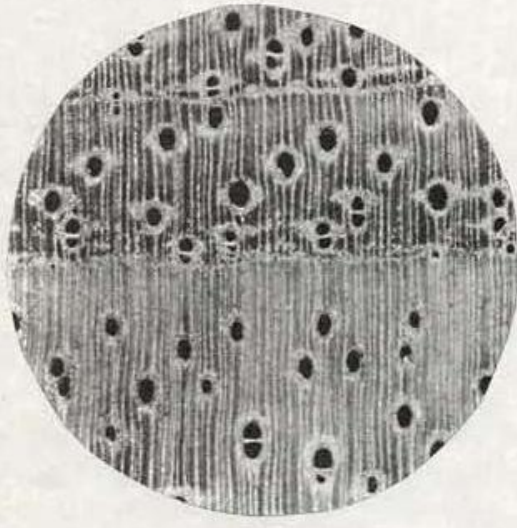

Foto 7 - Macrolobium acaciifolium
ARARA TUGUPI

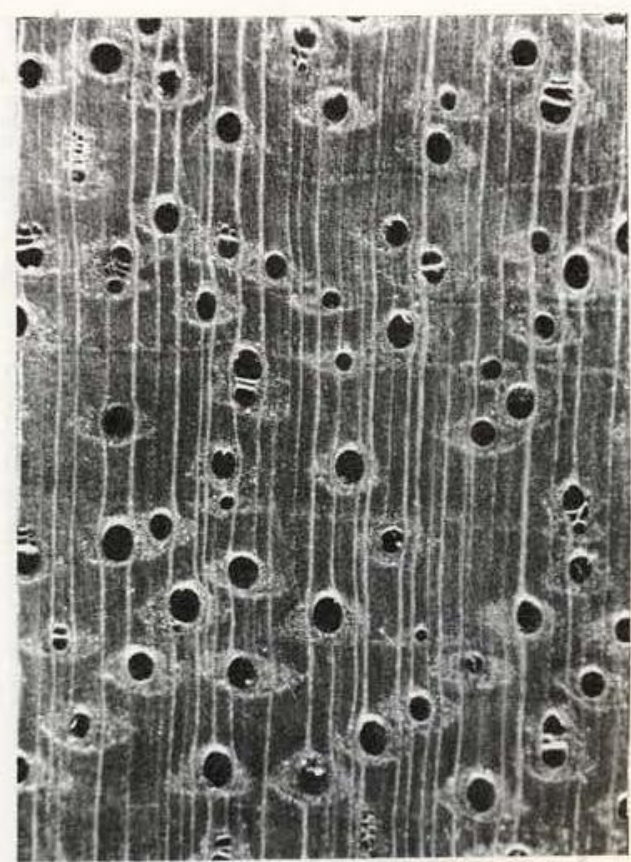

Foto 8 - Parkia pendula 


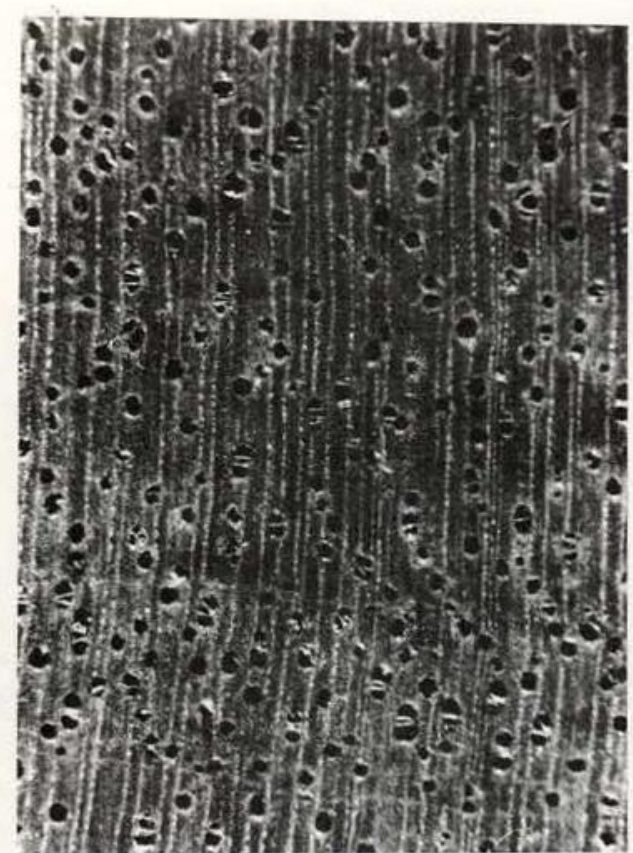

Foto 9 - Trattinickia rhoifolia

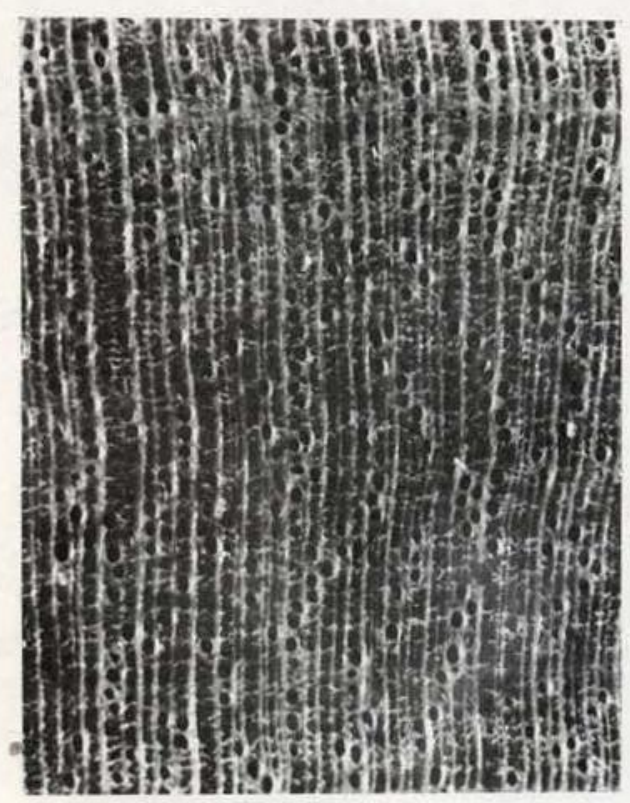

Foto 11 - Aptandra spruceana

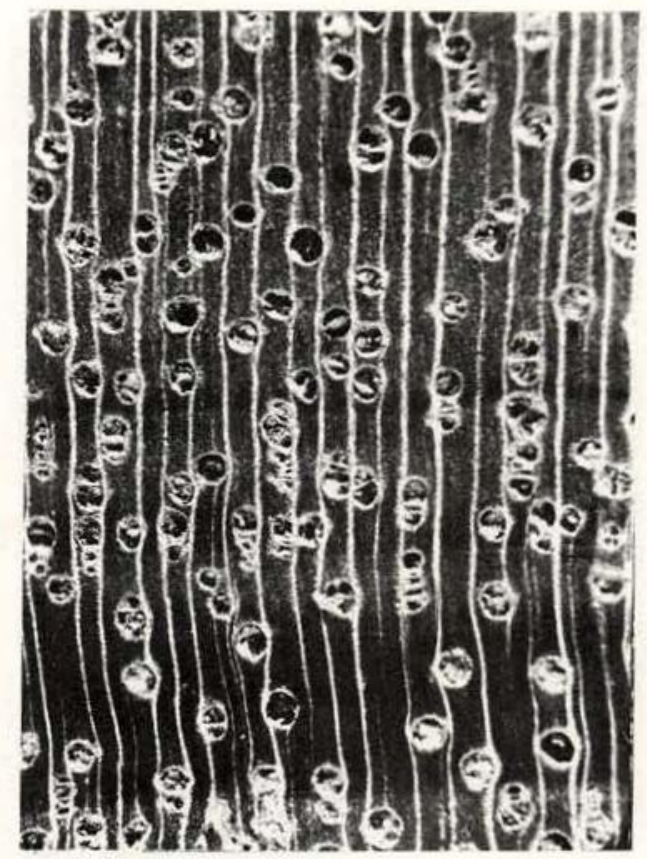

Foto 10 - Bagassa guianensis

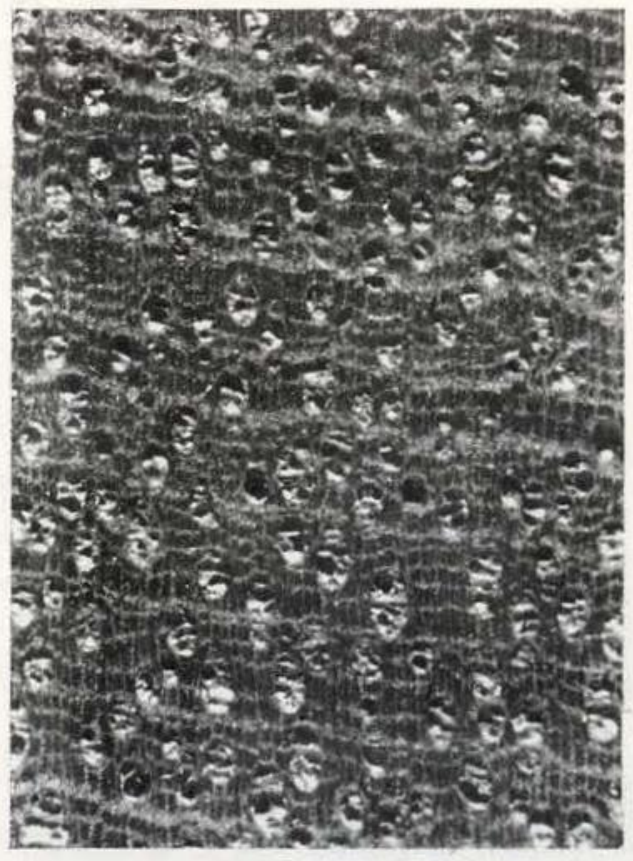

Foto 12 - Bertholletia excelsa 


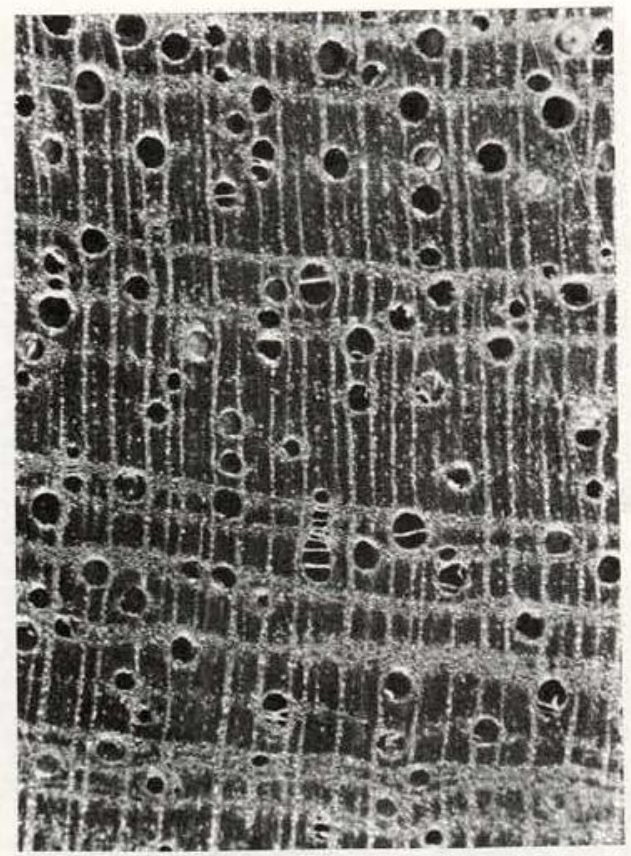

Foto 13 - Cedrela fissilis

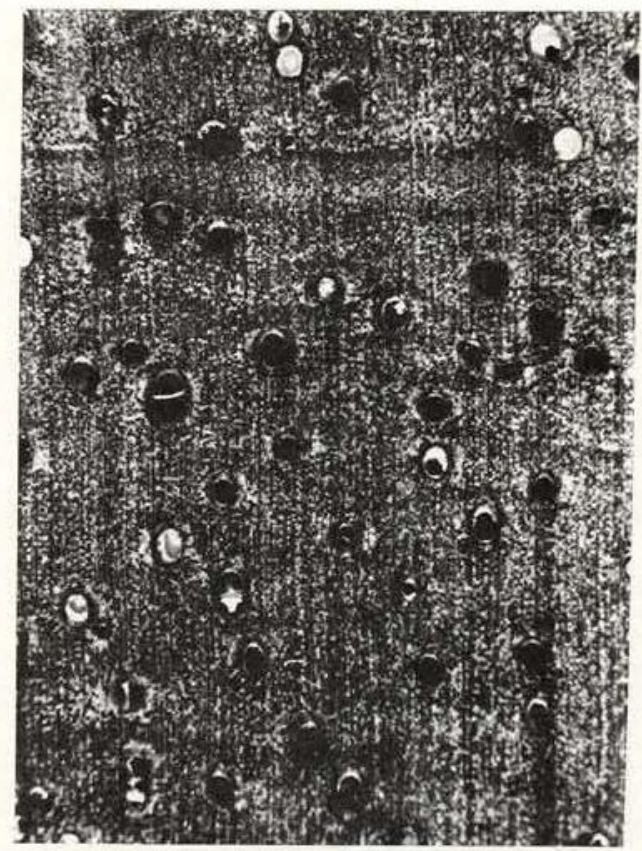

Foto 14 - Cedrelinga catenaeformis
GEREJEIRA

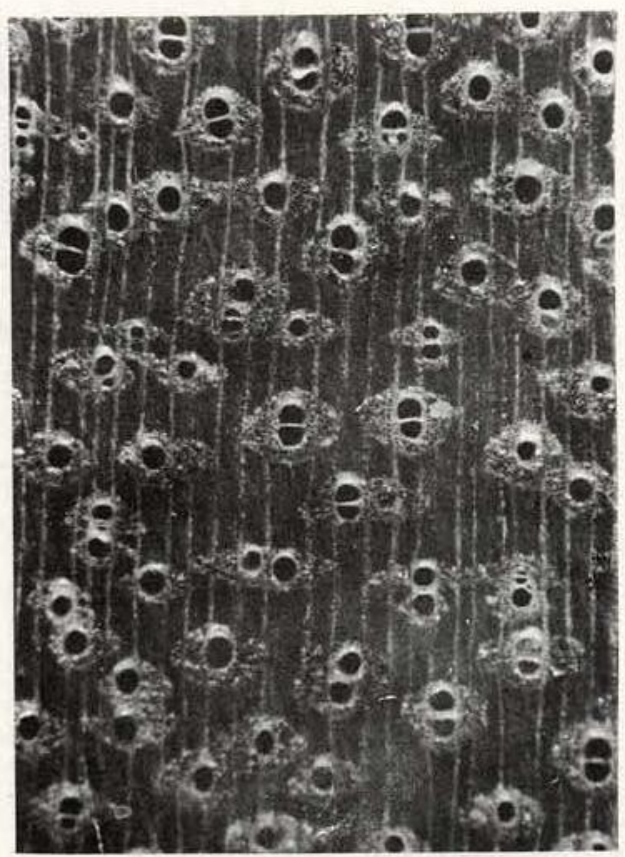

Foto 15 - Torresia acreana
COPAIBA

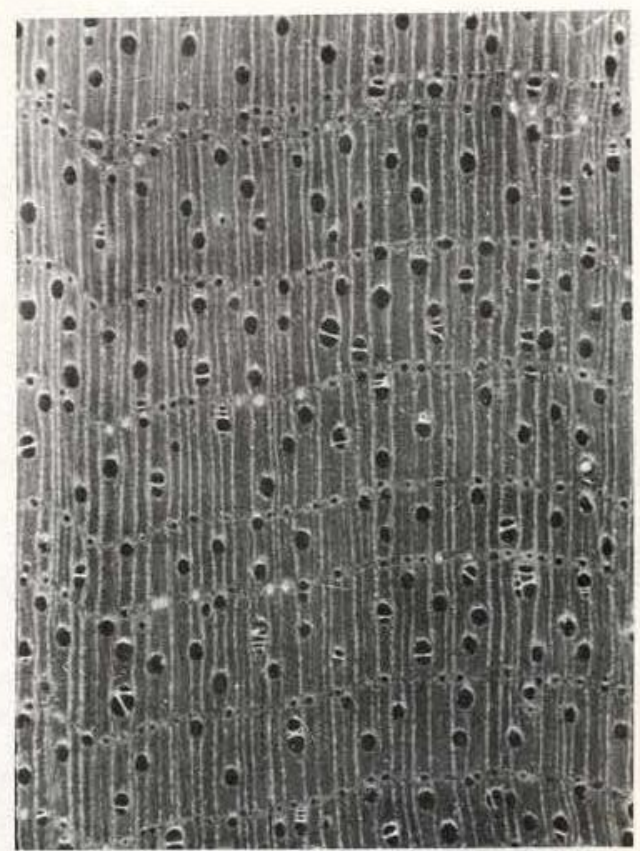

Foto 16 - Copaifera multijuga 


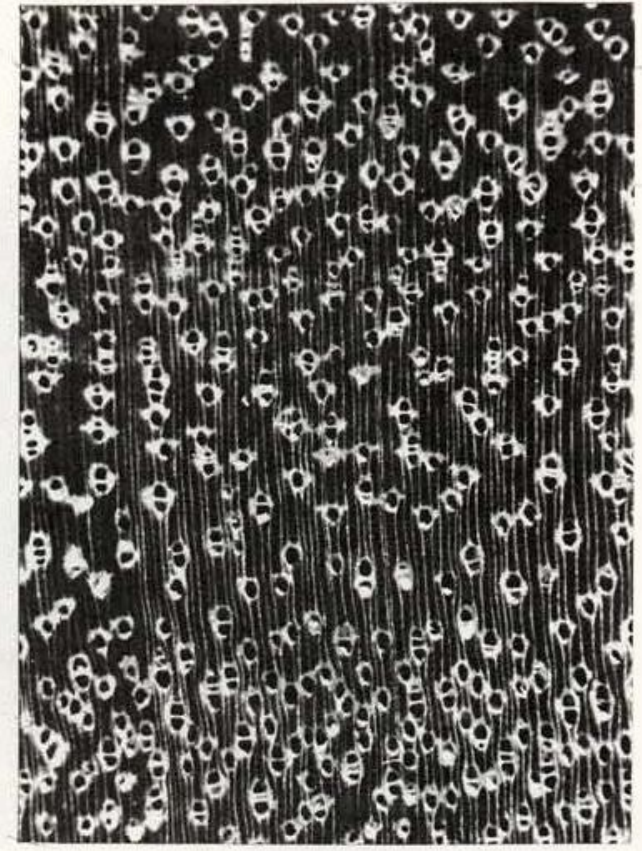

Foto 17 - Dipteryx odorata

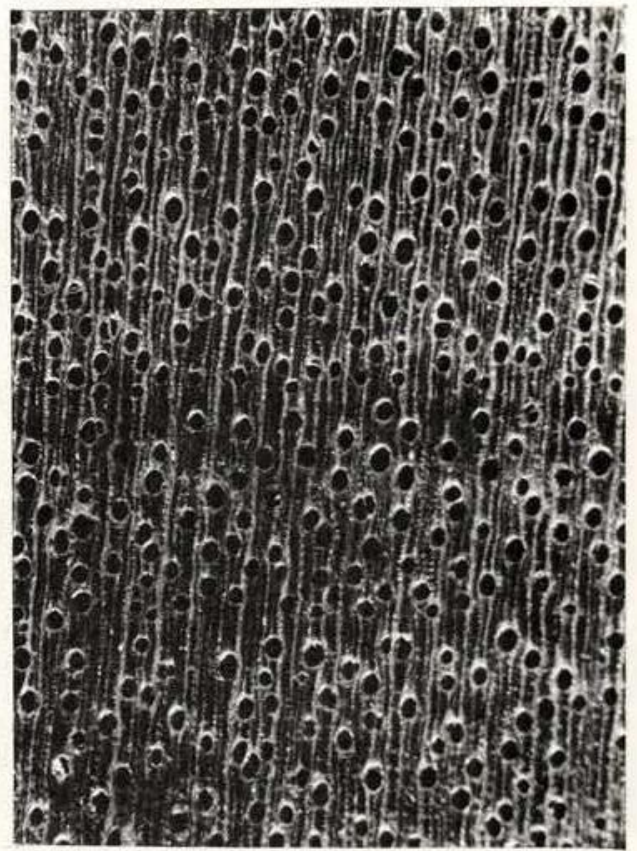

Foto 18 - Goupia glabra
ENVIRA SURUCUCU

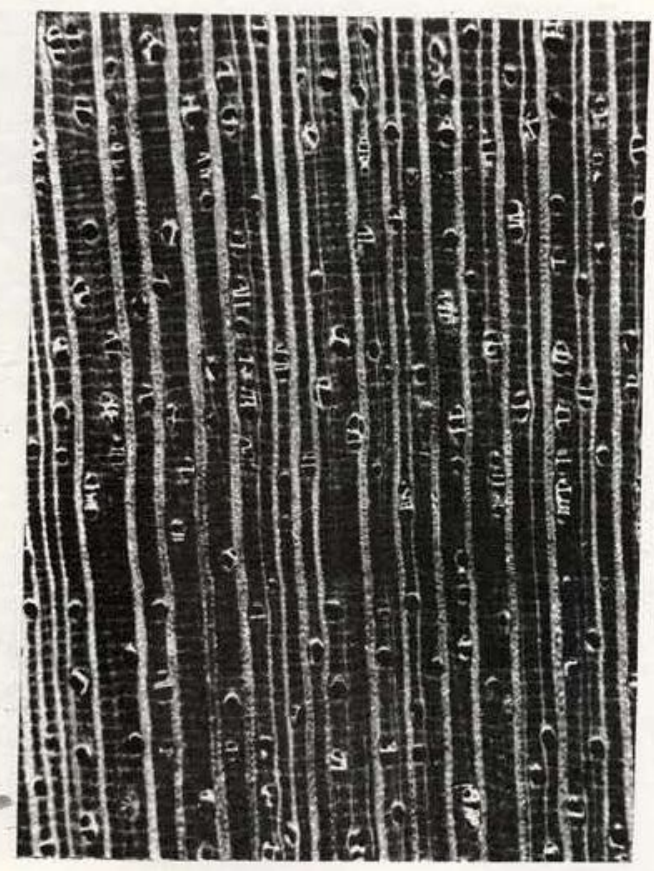

Foto 19 - Bocageopsis multiflora
FAVEIRA

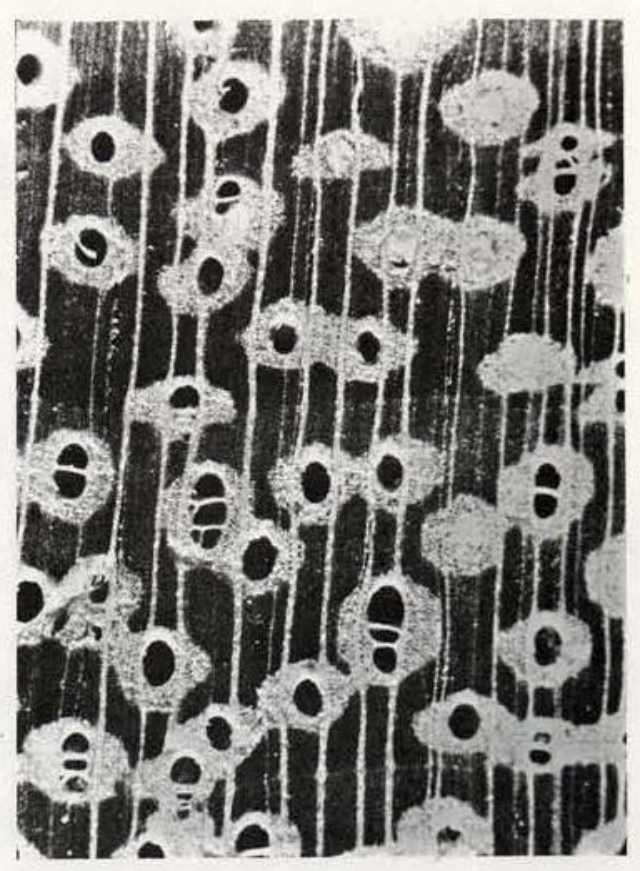

Foto 20 - Vatairea guianensis 
FAVEIRA DA VARZEA

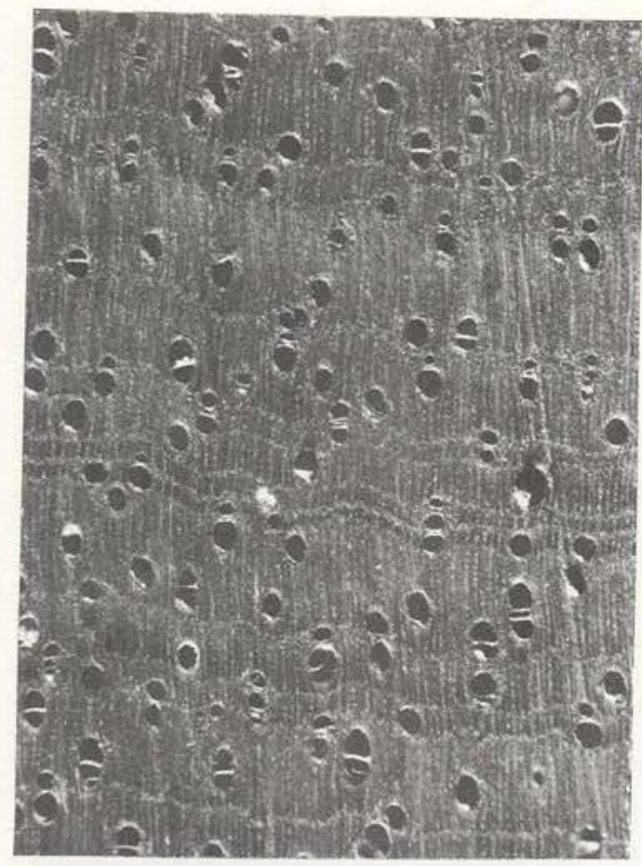

Foto 21 - Macrolobium angustifolium

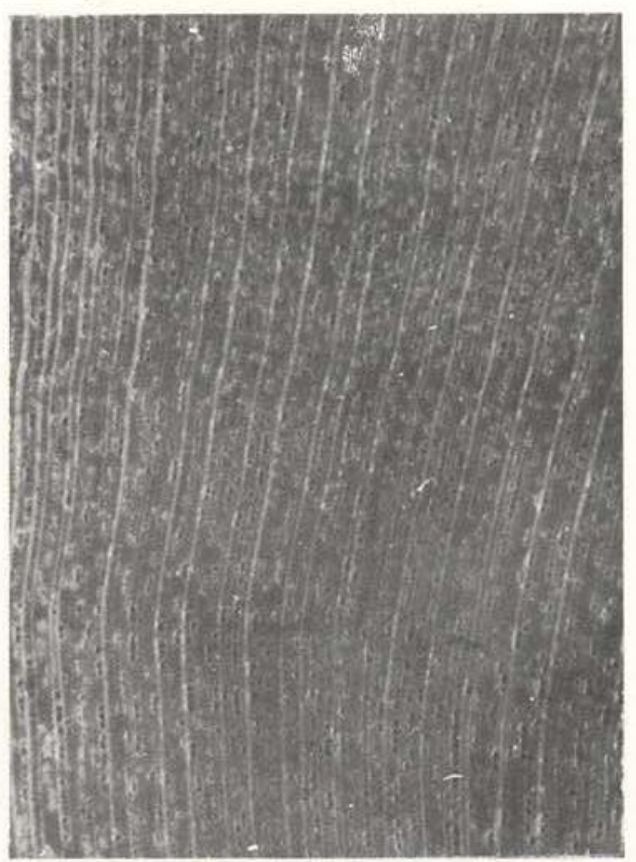

Foto 22 - Leonia glycicarpa
GONĢALO ALVES

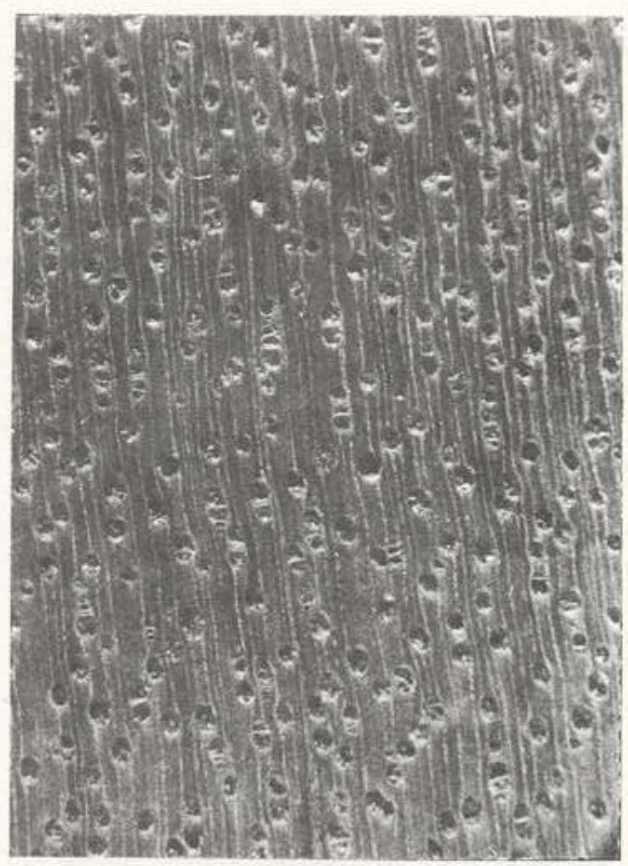

Foto 23 - Astronium fraxinifolium

JENIPAPO BRAVO 


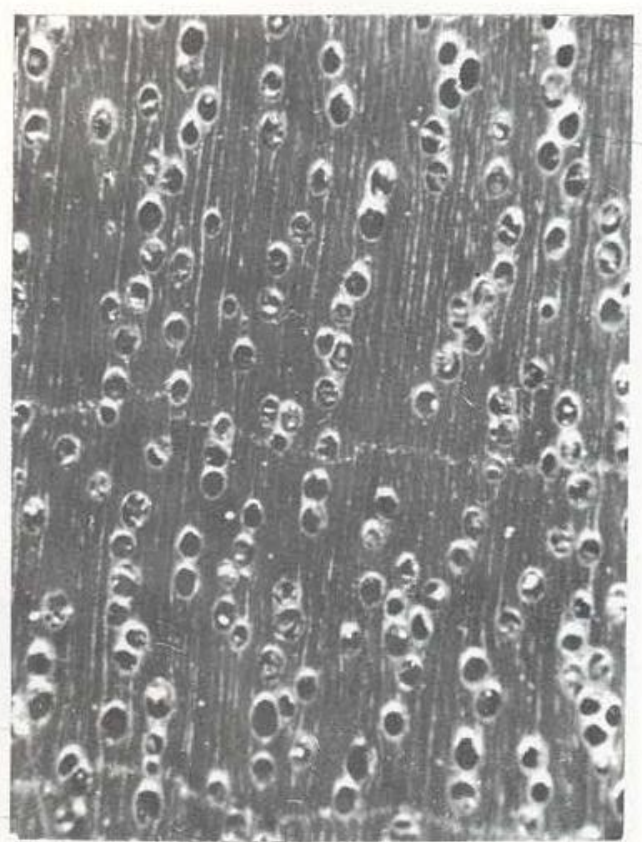

Foto 25 - Calophyllum brasiliense

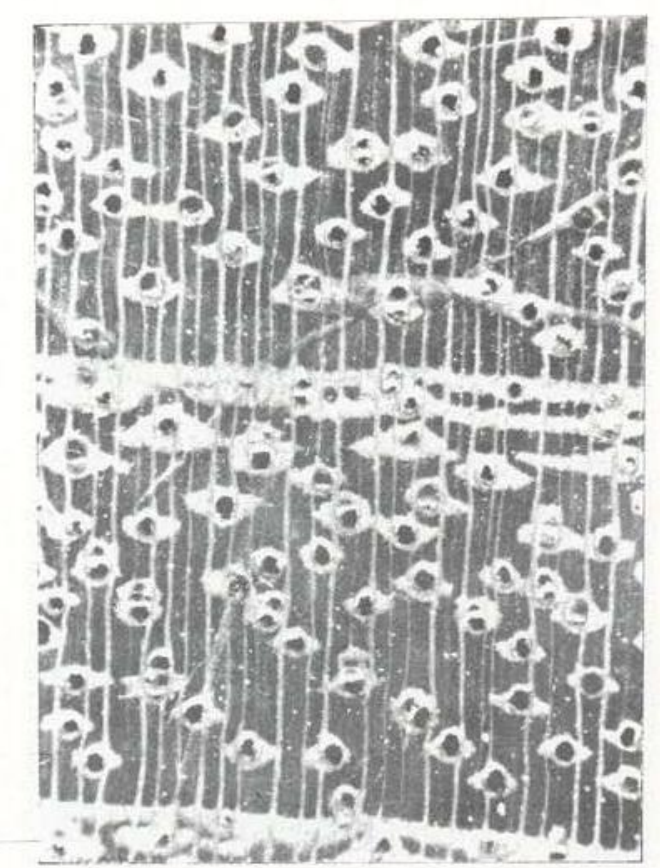

Foto 26 - Hymenaea courbaril
JUTAY-POROROCA

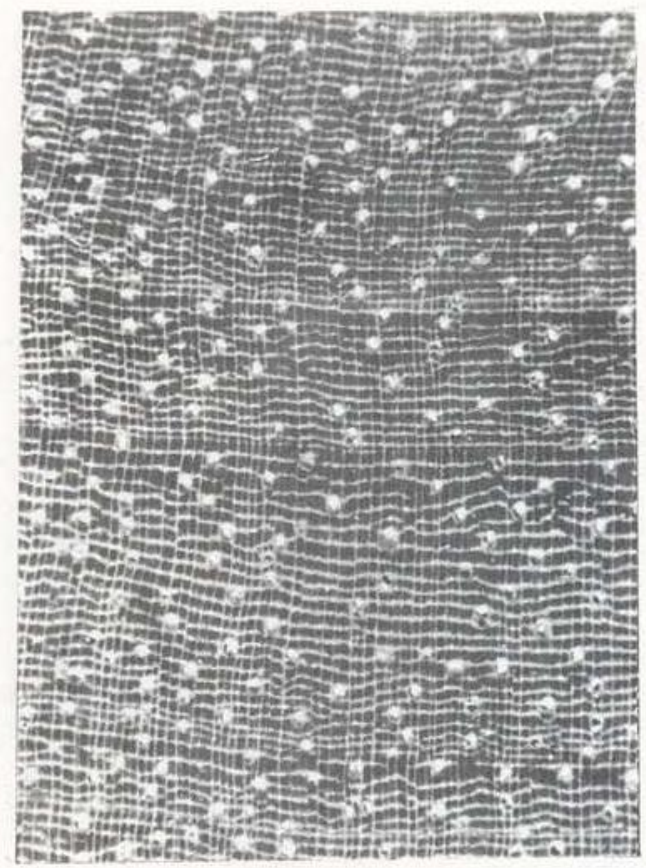

Foto 27 - Dialium guianense
LACRE

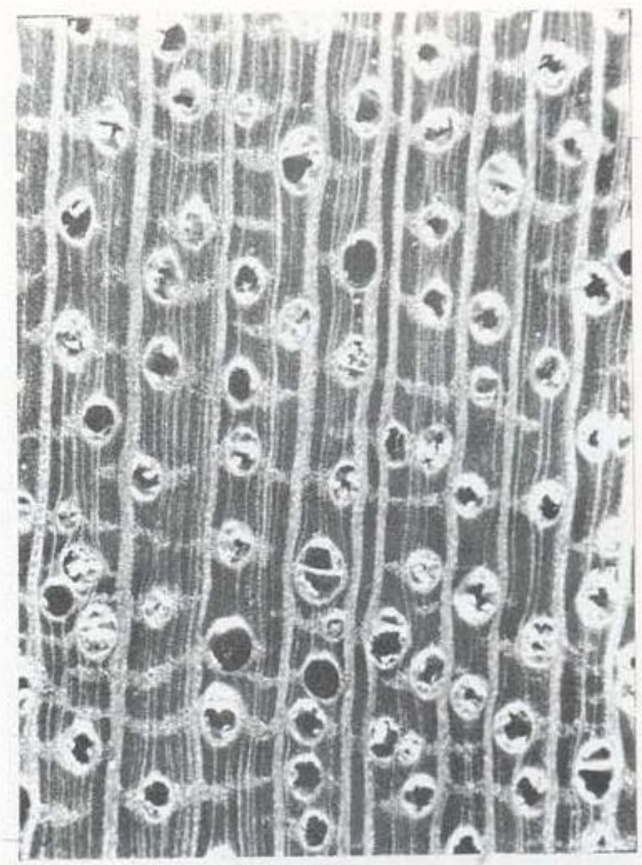

Foto 28 - Vochysia maxima 


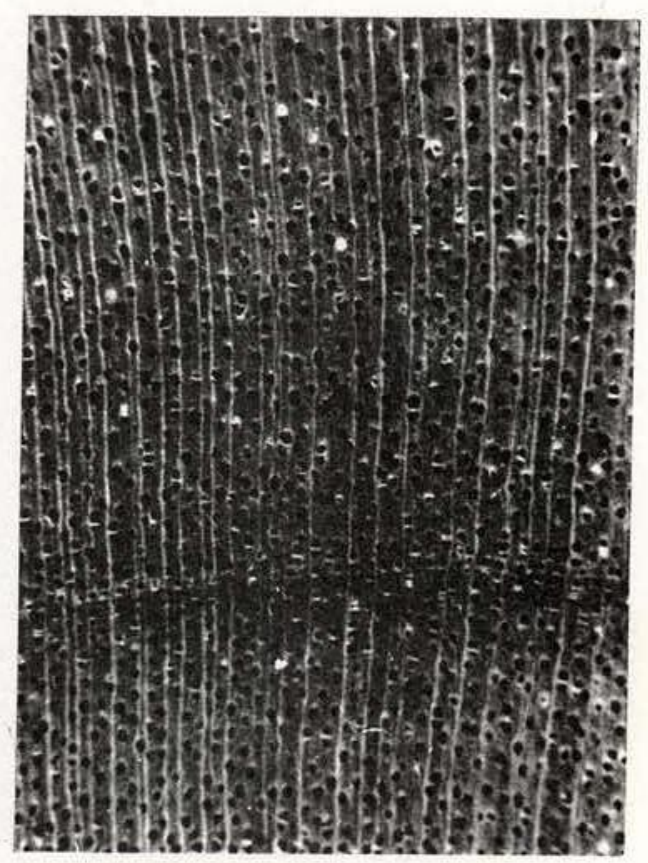

Foto 29 - Zanthoxylum rhoufolium

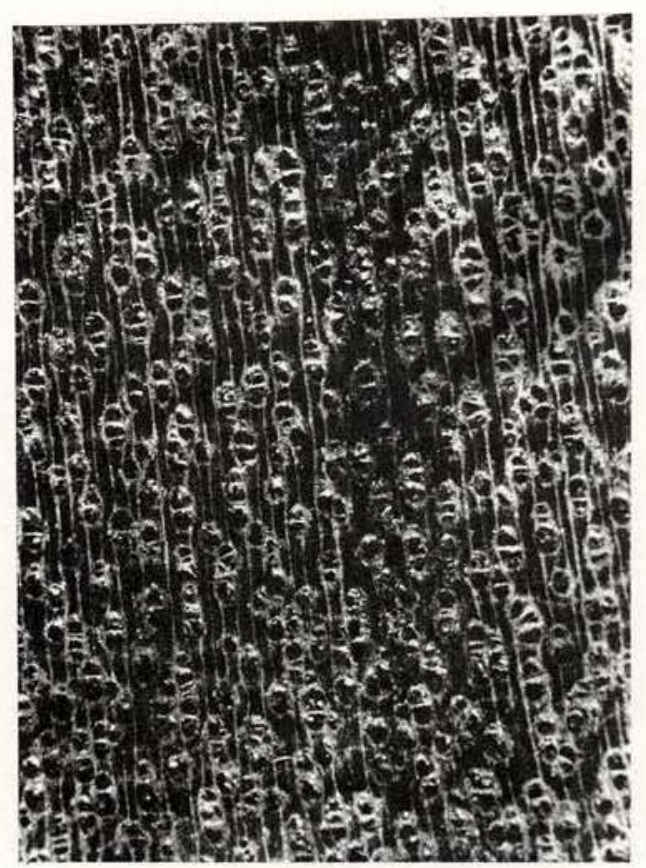

Foto 30 - Mezilaurus itauba
LOURO SUCENA

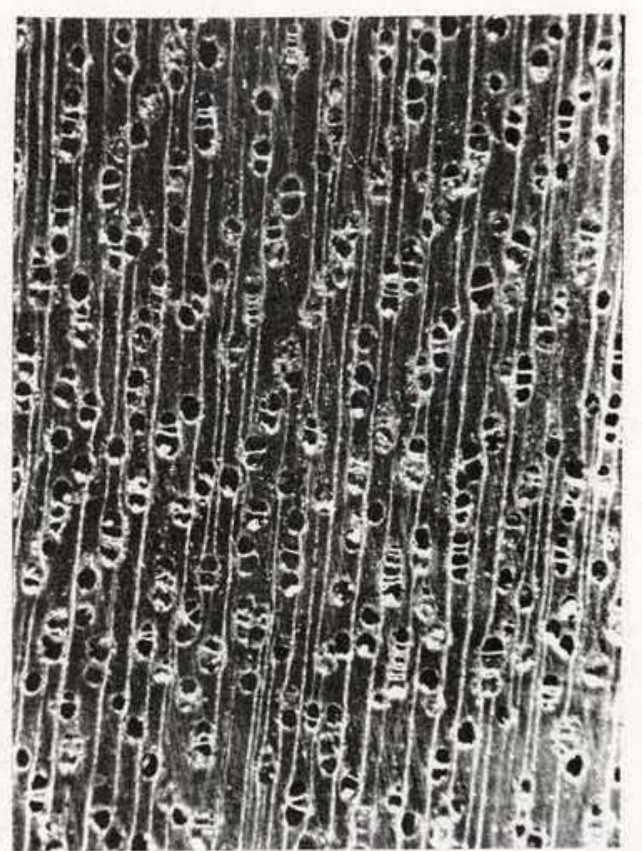

Foto 31 - Nectandra amazonum
MARUPA

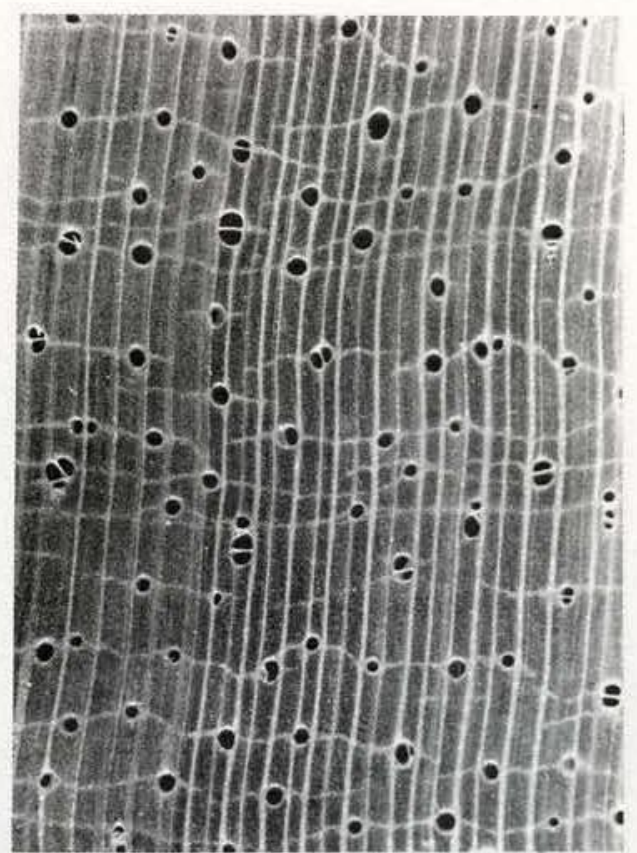

Foto 32 - Simaruba amara 


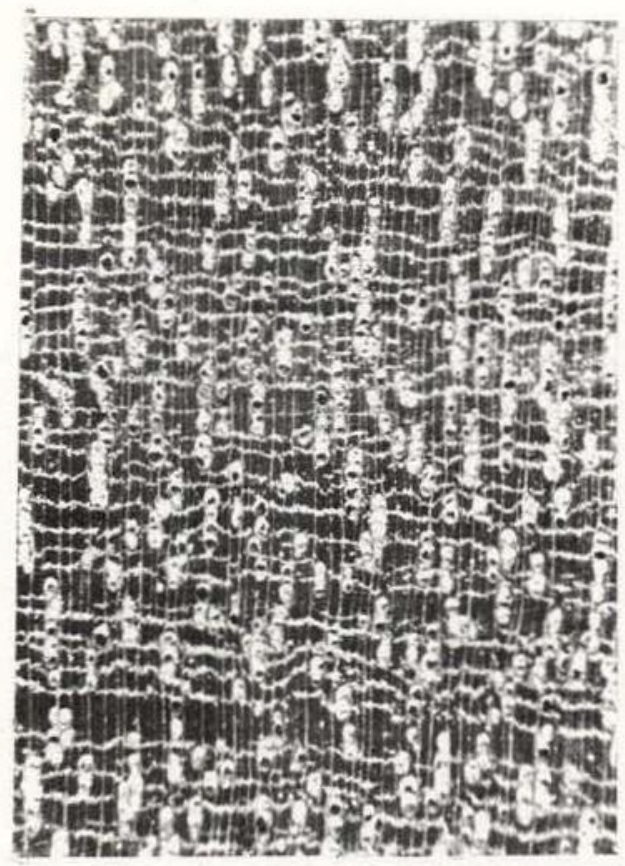

Foto 33 - Manilkara huberi

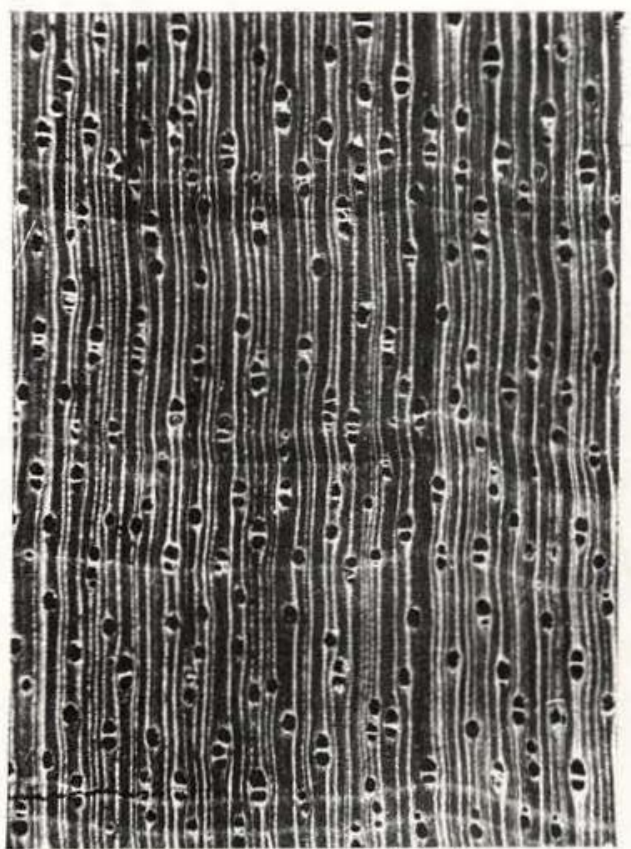

Foto 34 - Virola calophylla
MATA MATA

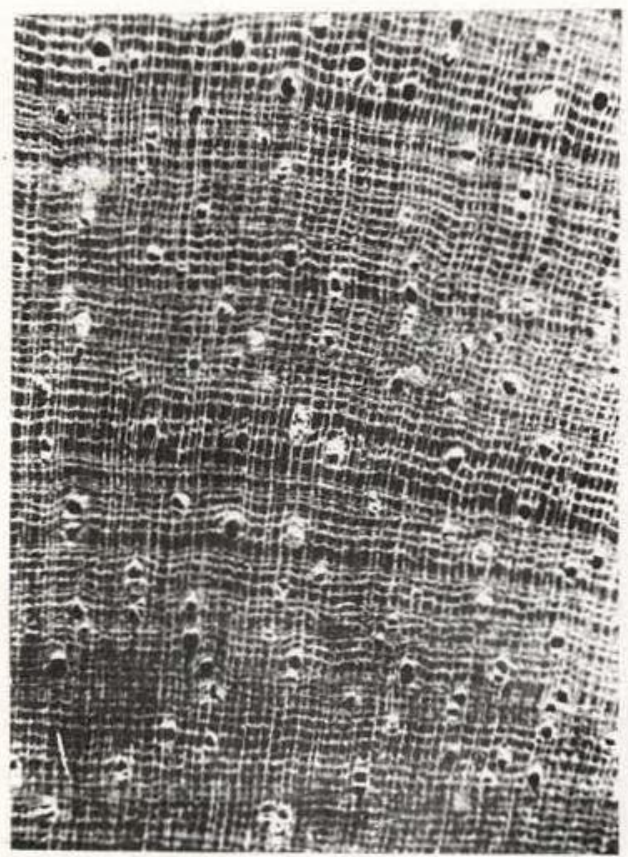

Foto 35 - Eschweilera fracta
MOGNO

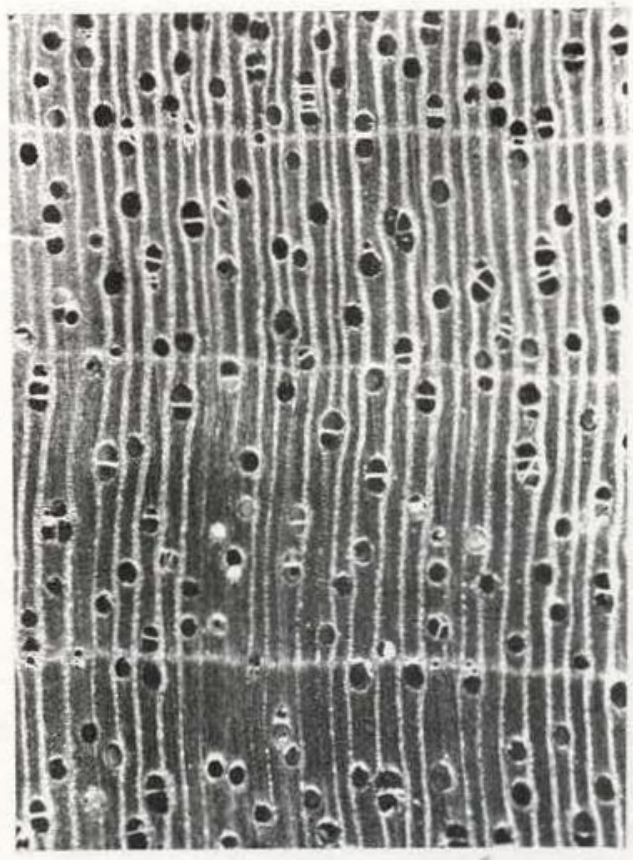

Foto 36 - Swietenia macrophylla 


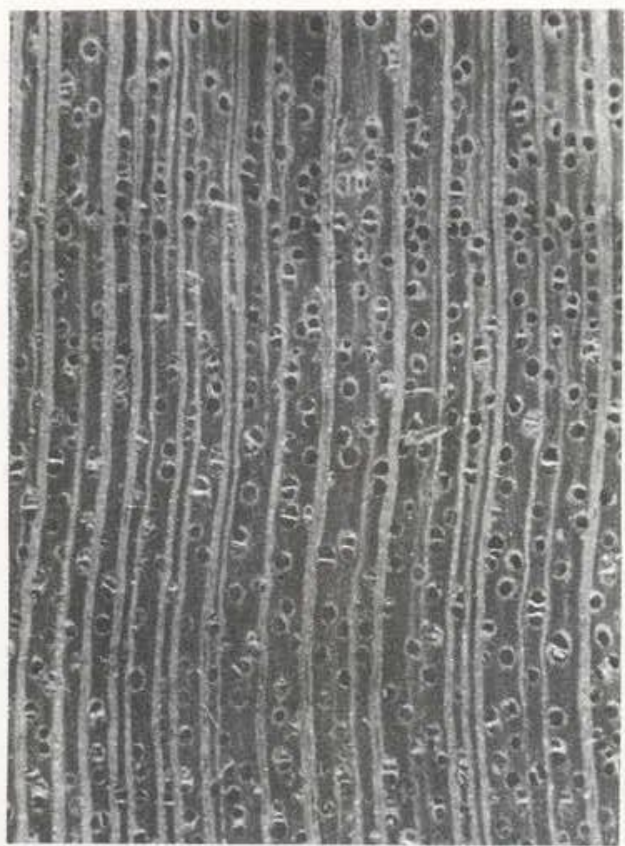

Foto 37 - Didymopanax morototoni

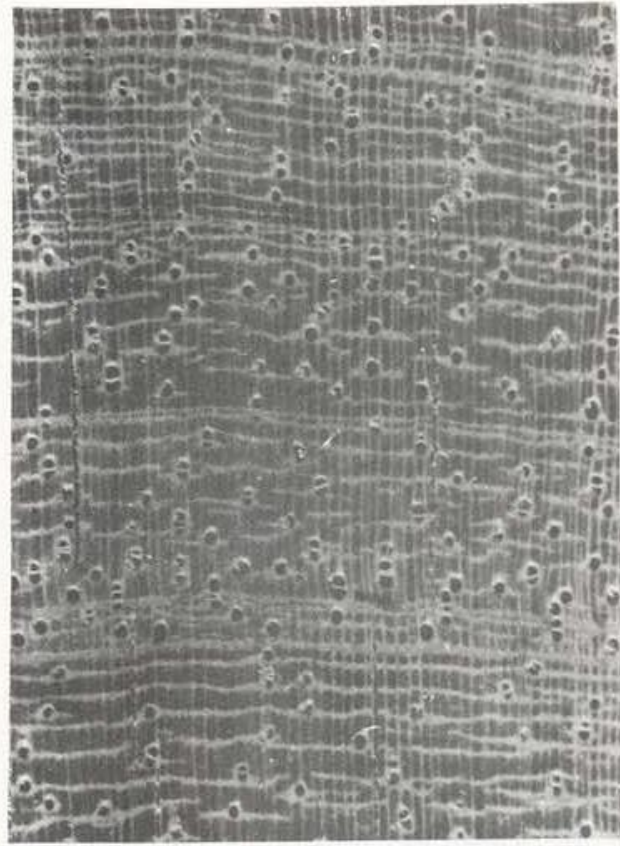

Foto 38 - Swartzia recurva
MUIRAJUBA

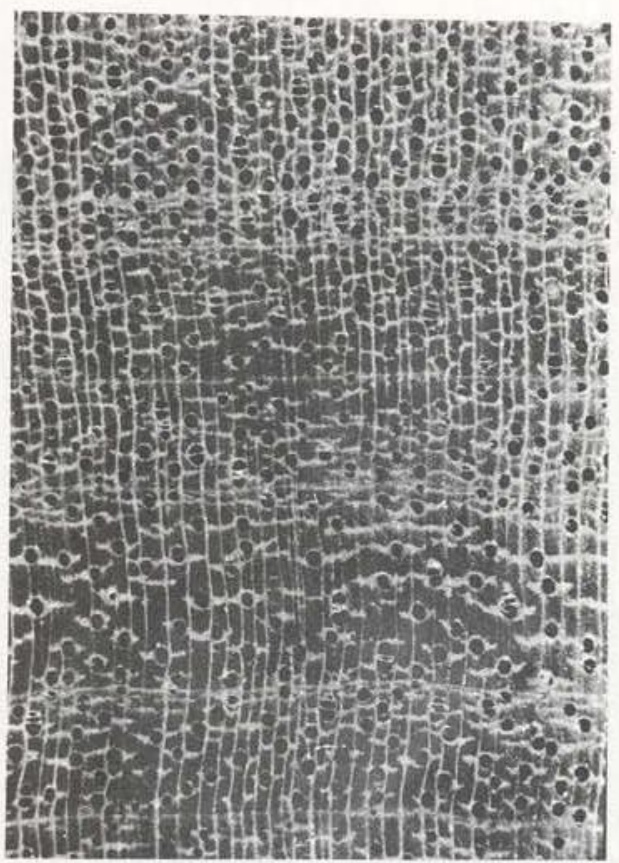

Foto 39 - Apuleia molaris
MUIRAPINIMA

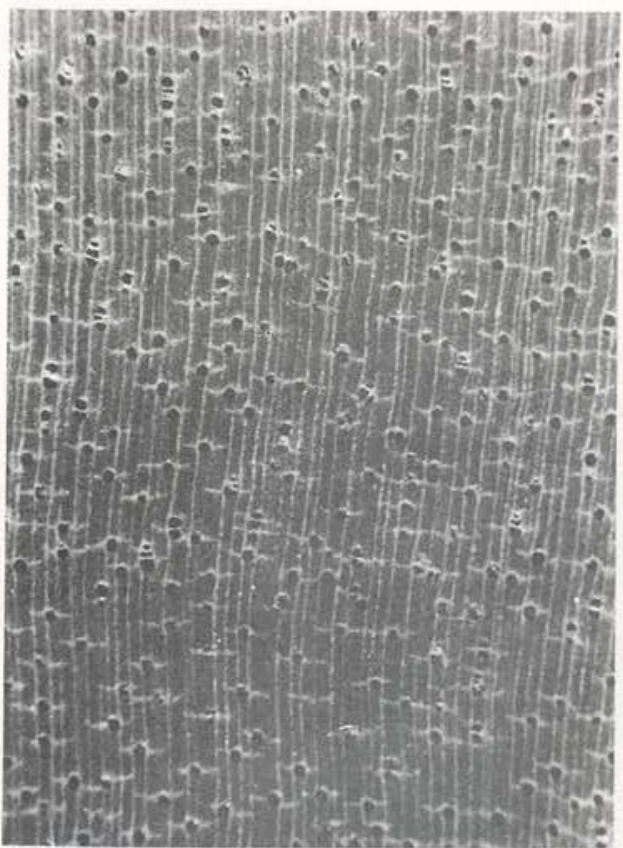

Foto $40-$ Brosimum guianensis 


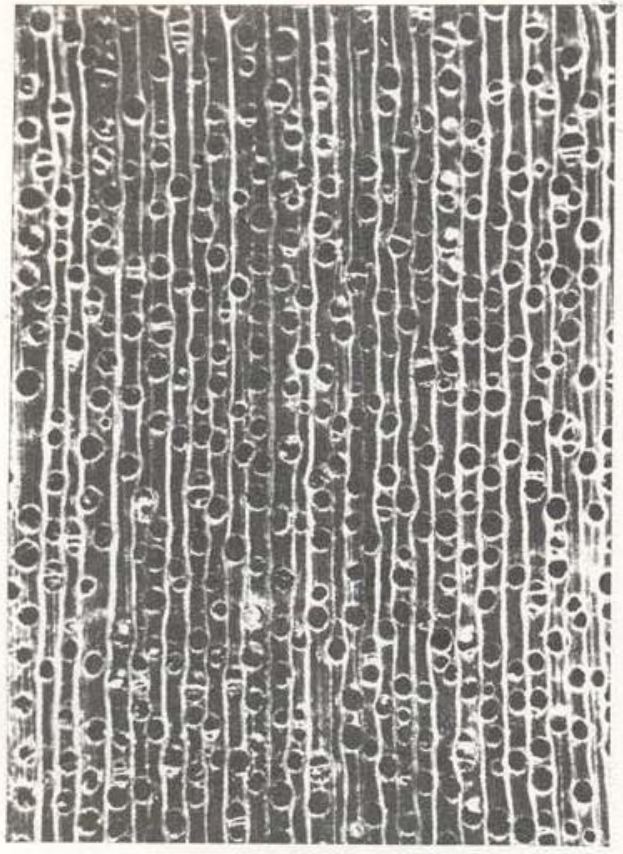

Foto 41 - Maquira coriaceae

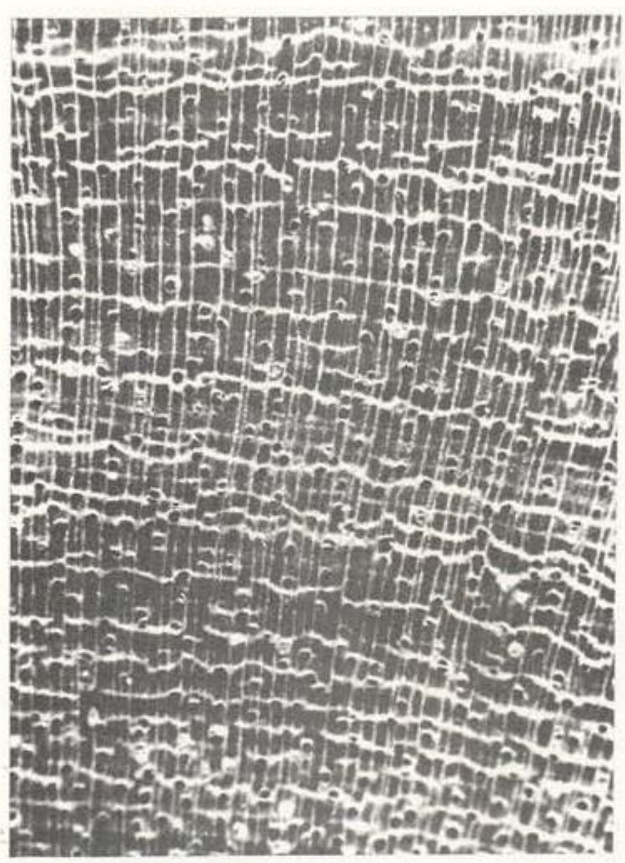

Foto 42 - Maquira guianensis
MUTUTI

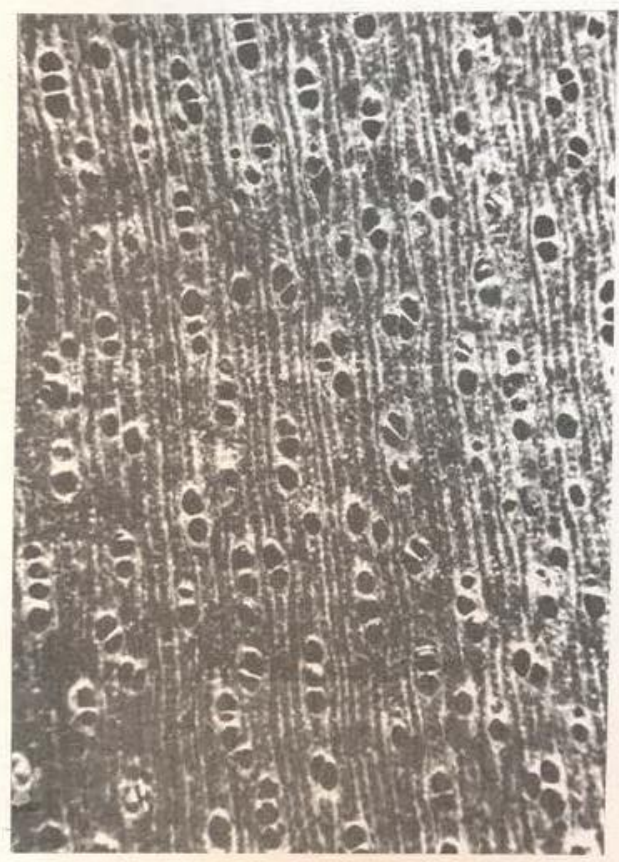

Foto 43 - Ptychopetalum olacoides
PARÁ PARA

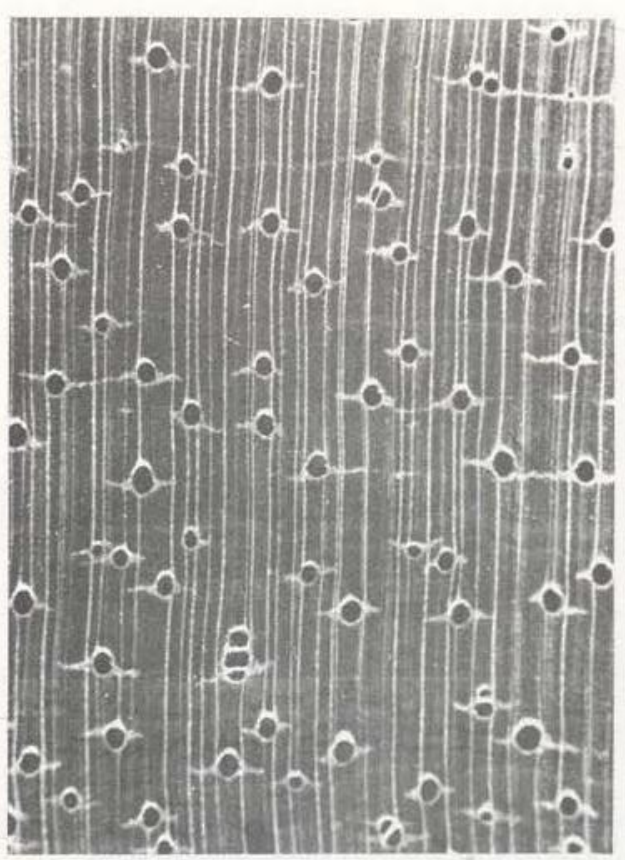

Foto 44 - Jacaranda copaia 


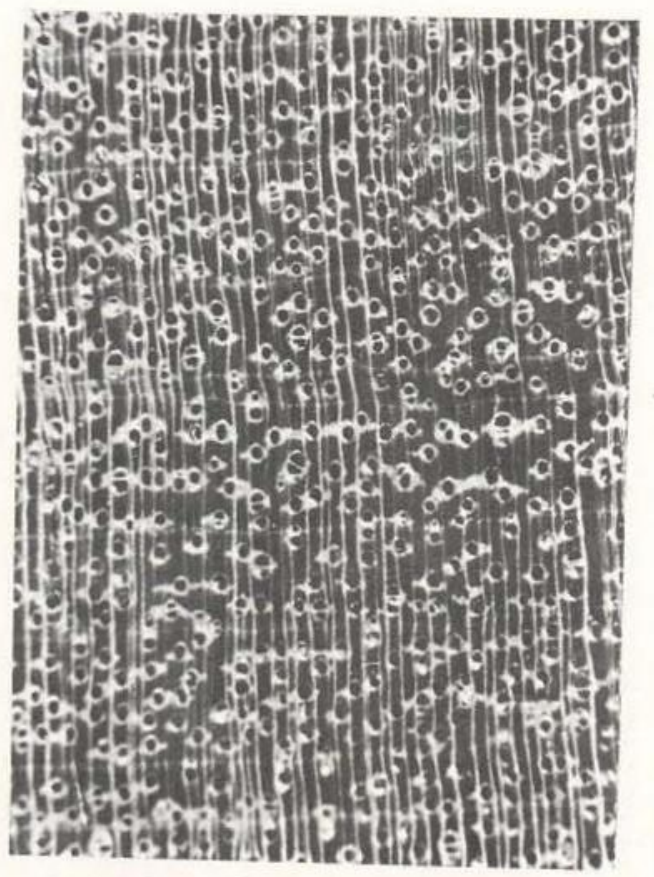

Foto 45 - Tabebuia serratifolia

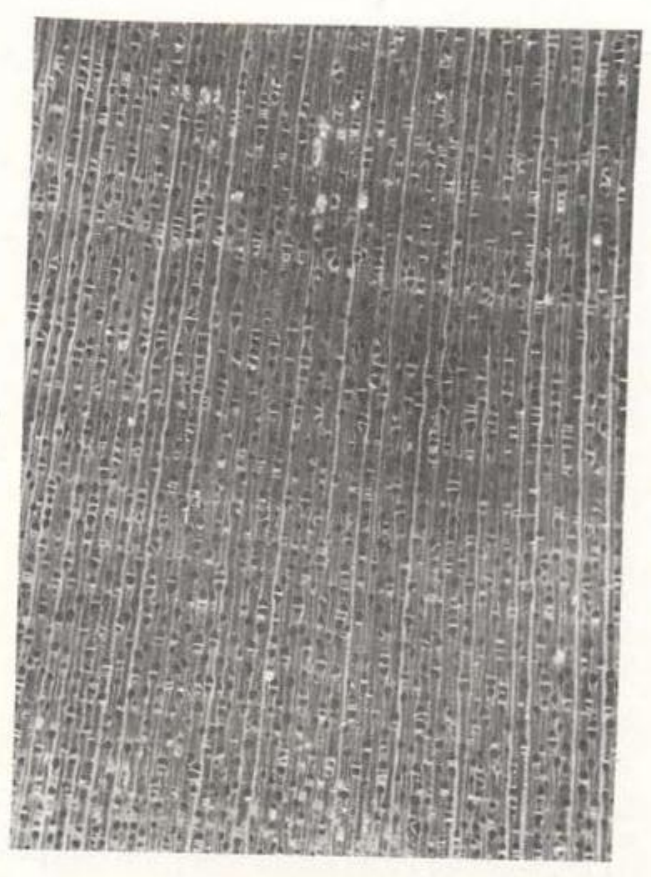

Foto 46 - Calycophyllum acreanum

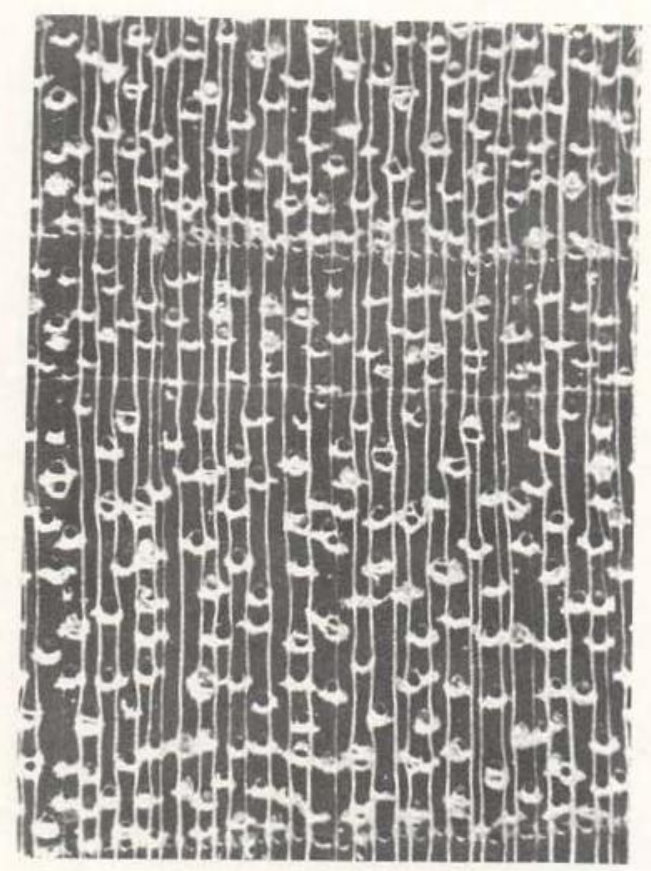

Foto 47 - Peltogyne lecointei

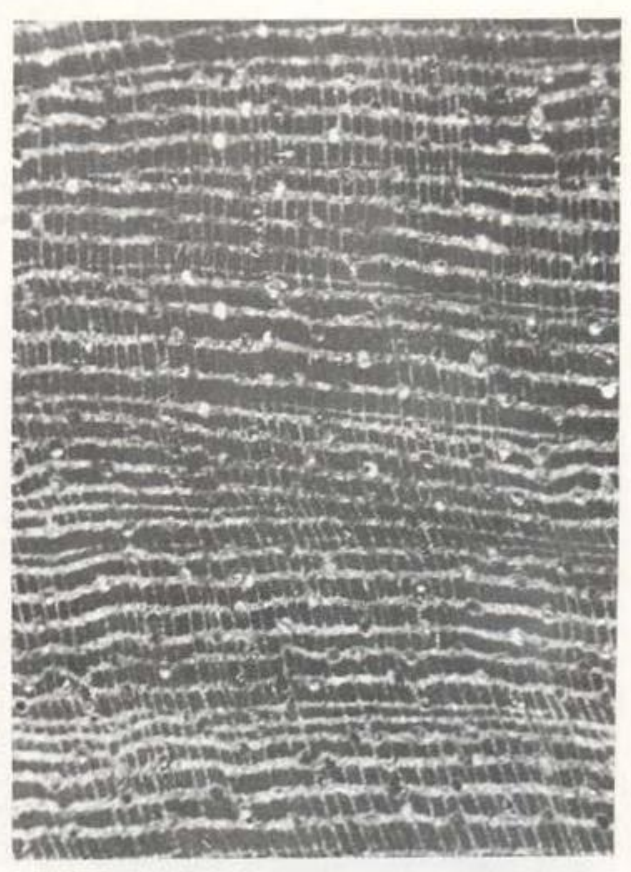

Foto 48 - Zollernia paraensis 
PEROBA

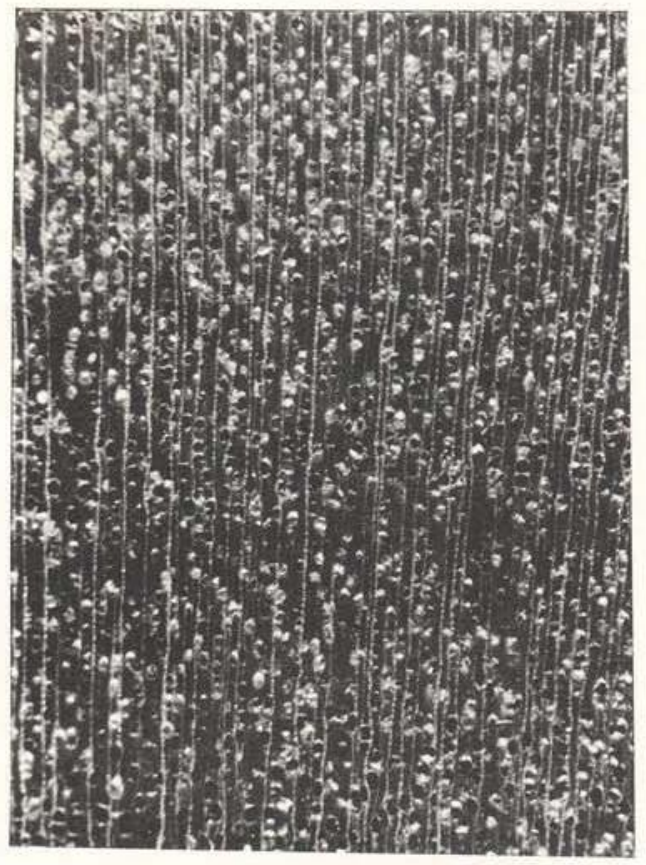

Foto 49 - Aspidosperma polyneuron
PIQUIARANA

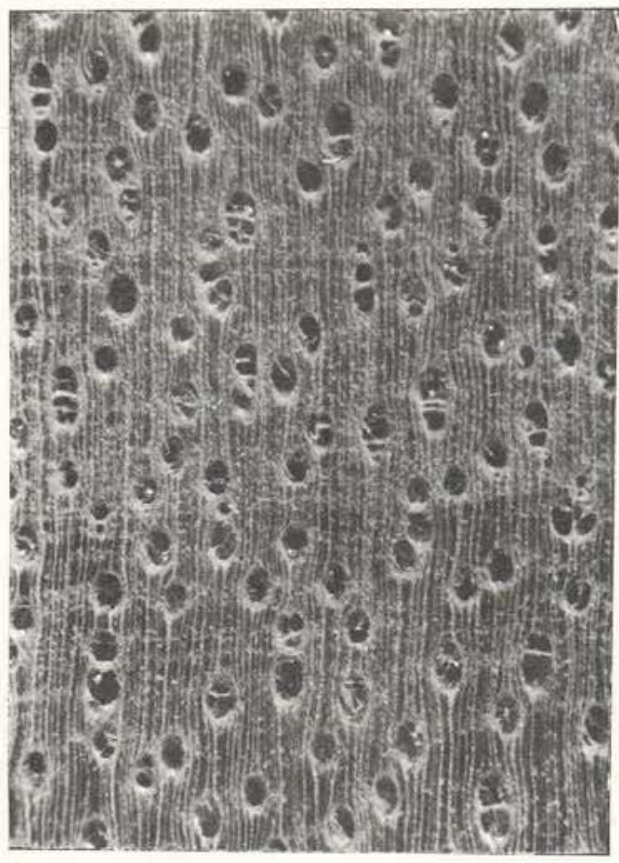

Foto 50 - Caryocar glabrum

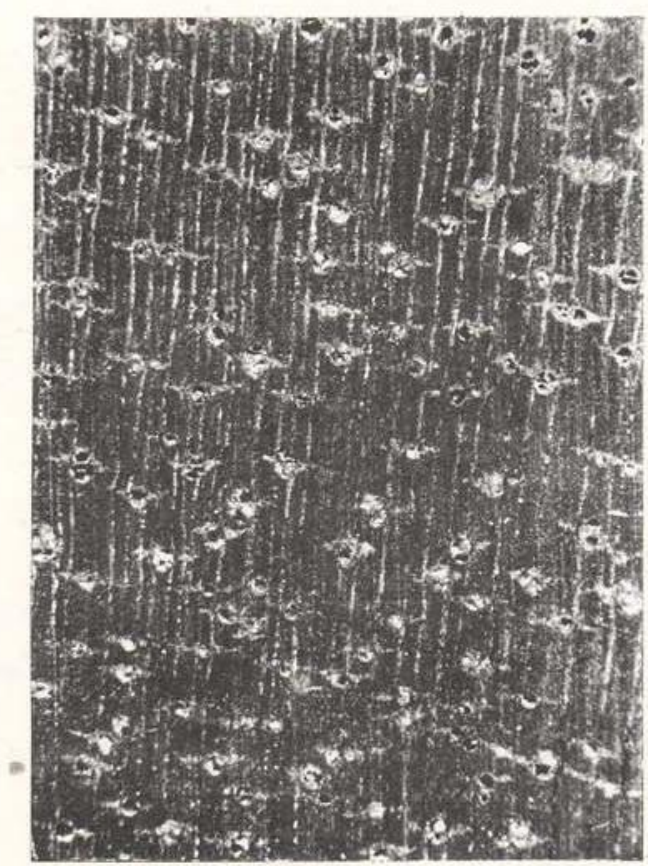

Foto 51 - Brosimum rubescens
SANGUE DE BOI

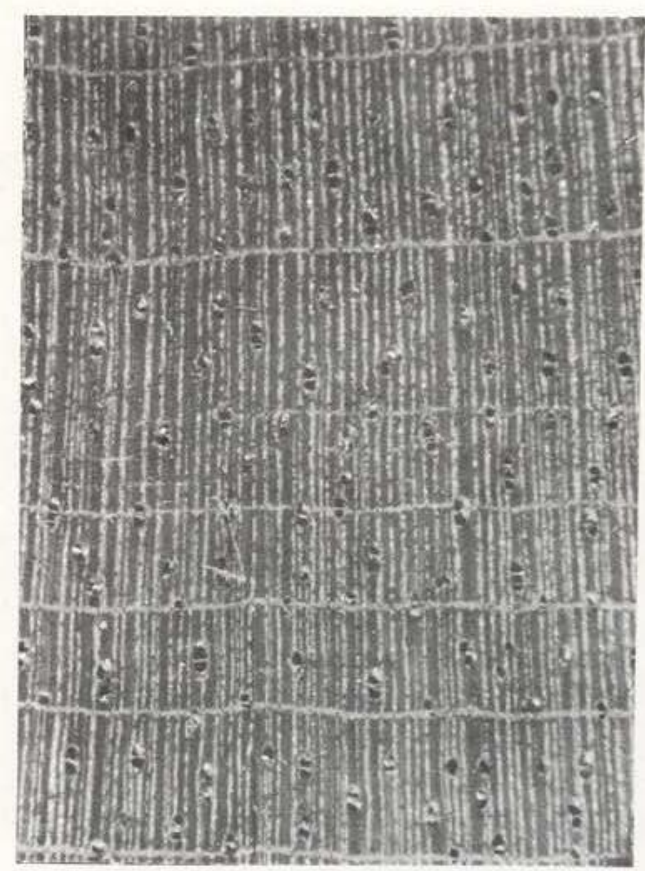

Foto 52 - Iryanthera juruensis 


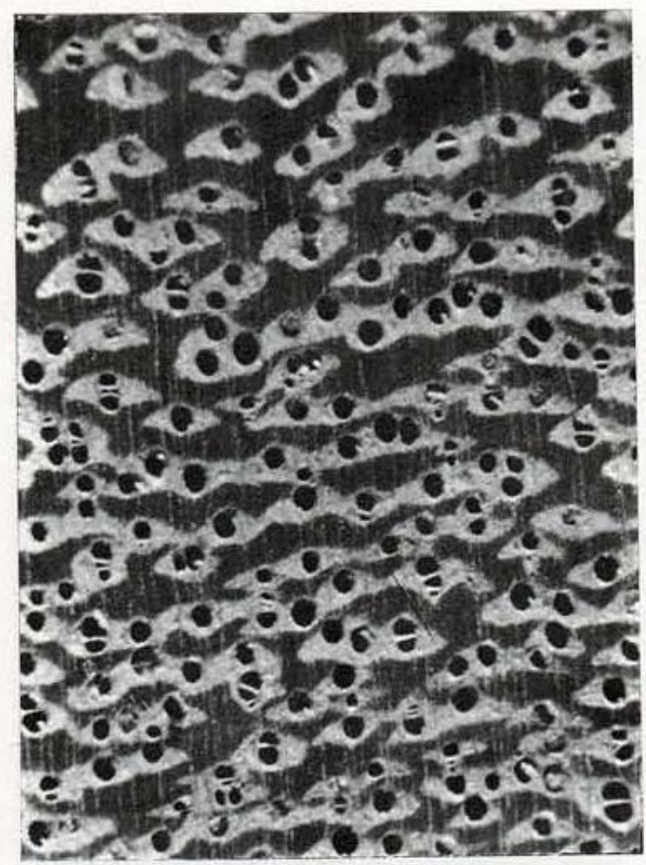

Foto 53 - Cassia adiantifolia

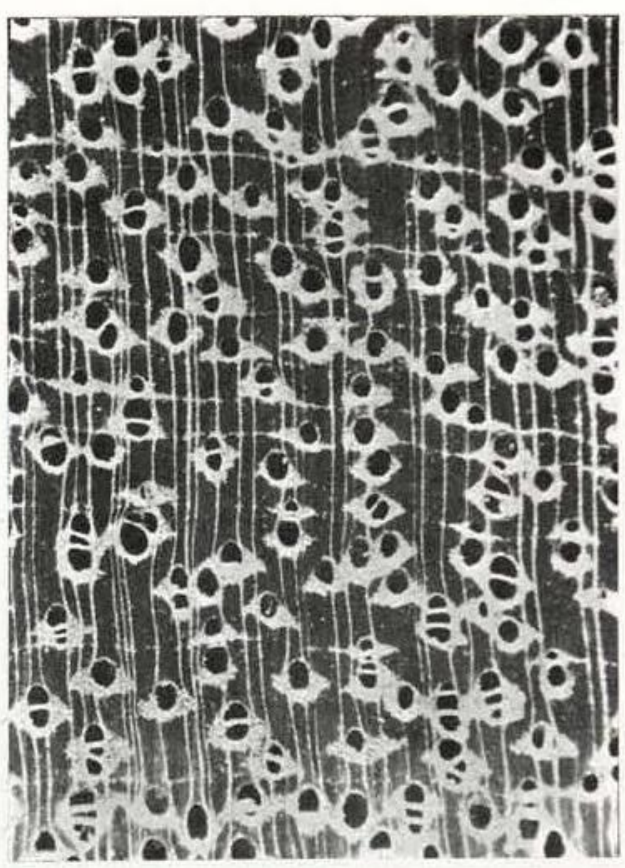

Foto 54 - Bowdichia nitida
TABINHEIRO

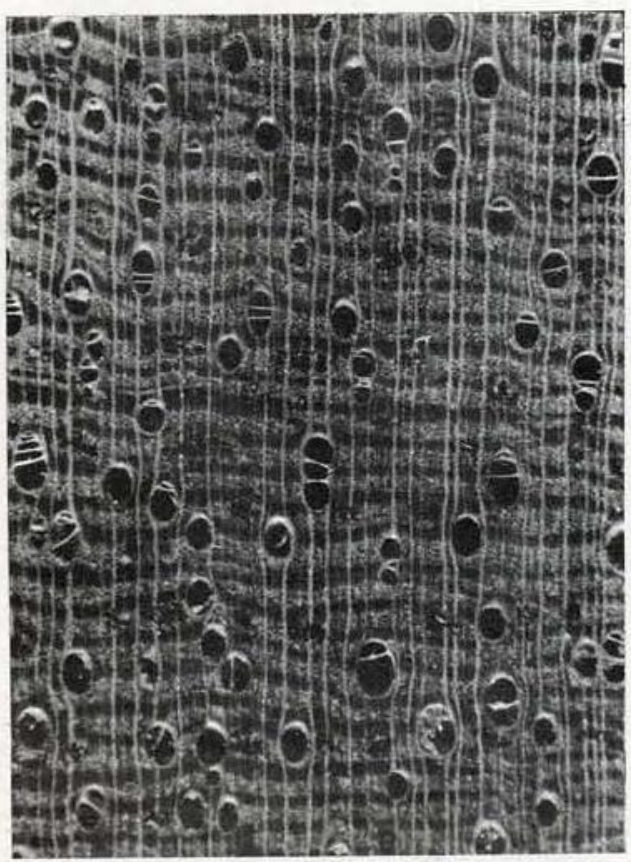

Foto 55 - Erisma uncinatum
TACHI

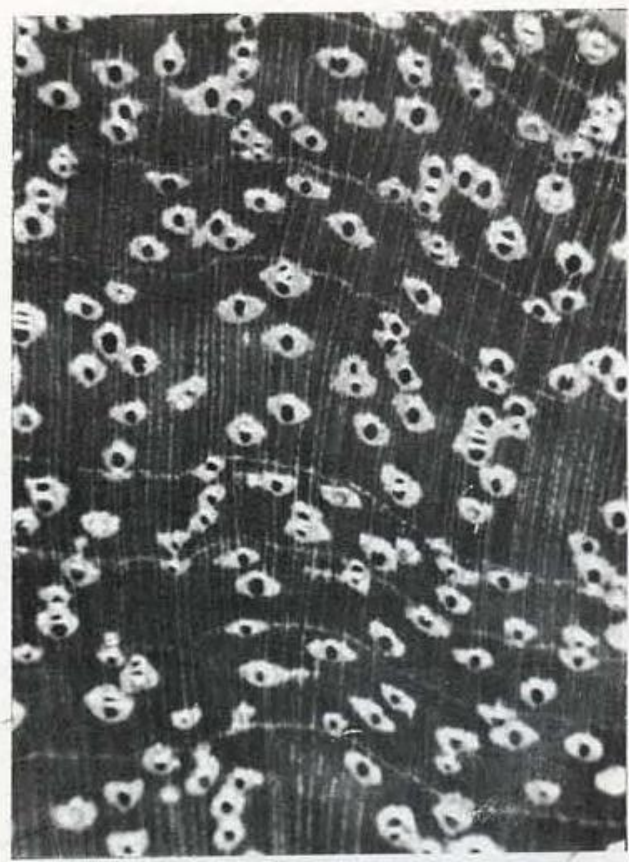

Foto 56 - Tachigalia paniculata 


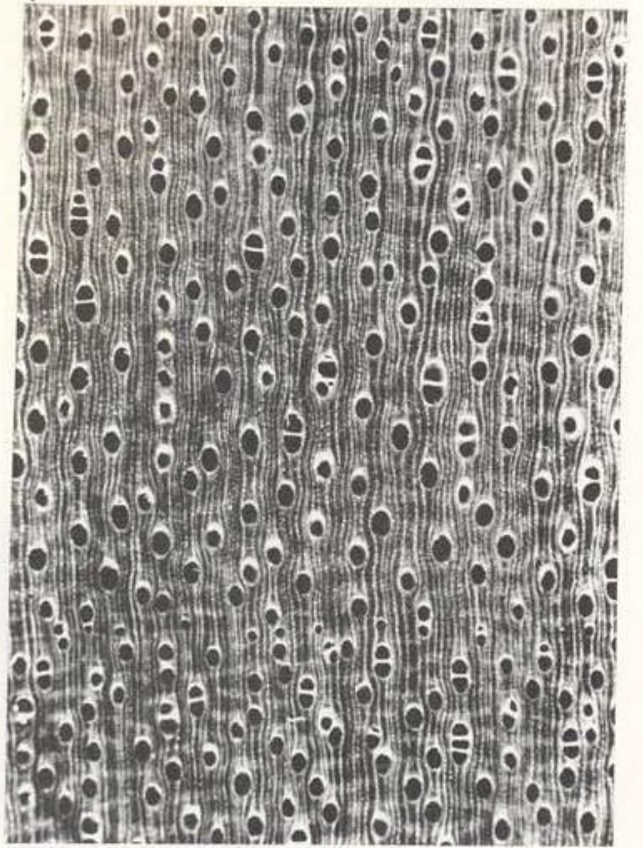

Foto 57 - Miconia poeppigii

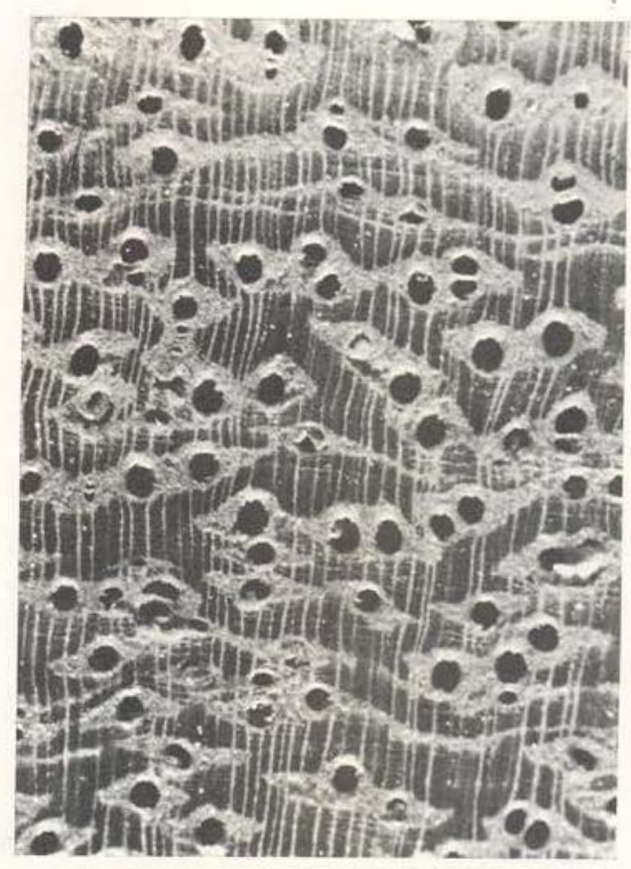

Foto 58 - Ormosia paraensis
UCUƯBA

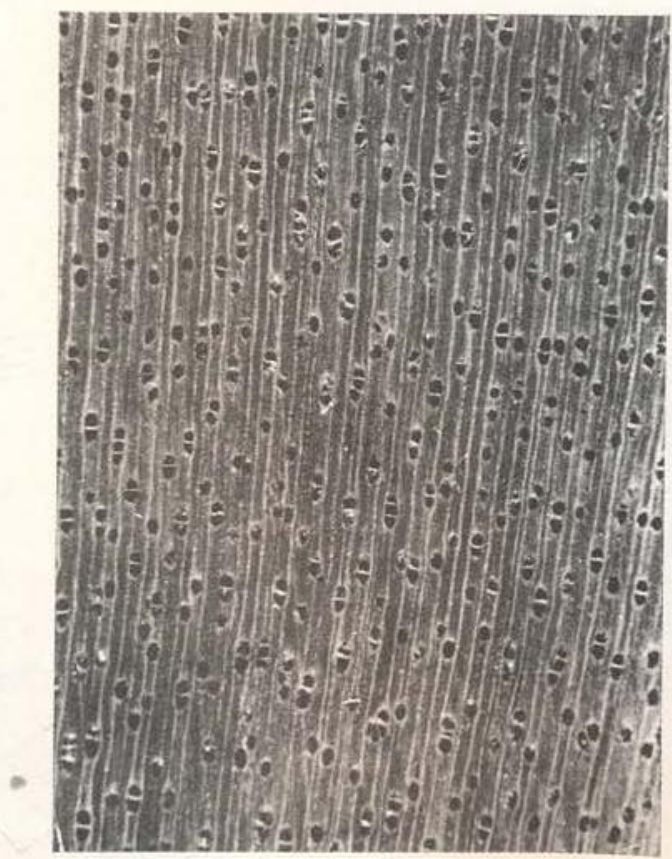

Foto 59 - Virola elongata
UCUƯBA

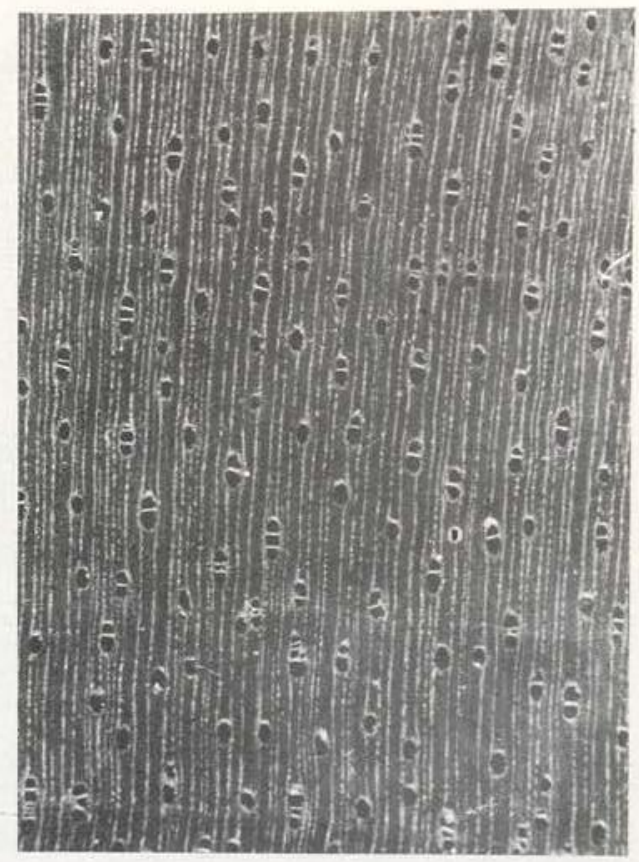

Foto 60 - Virola pavonis 
UCUUBARANA

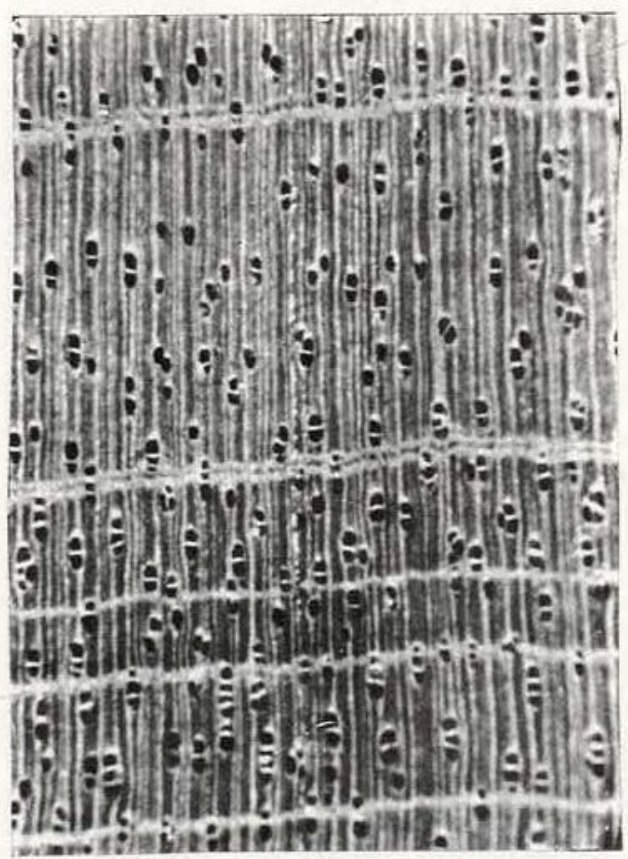

Foto 61 - Iryanthera laevis
UCUUBARANA

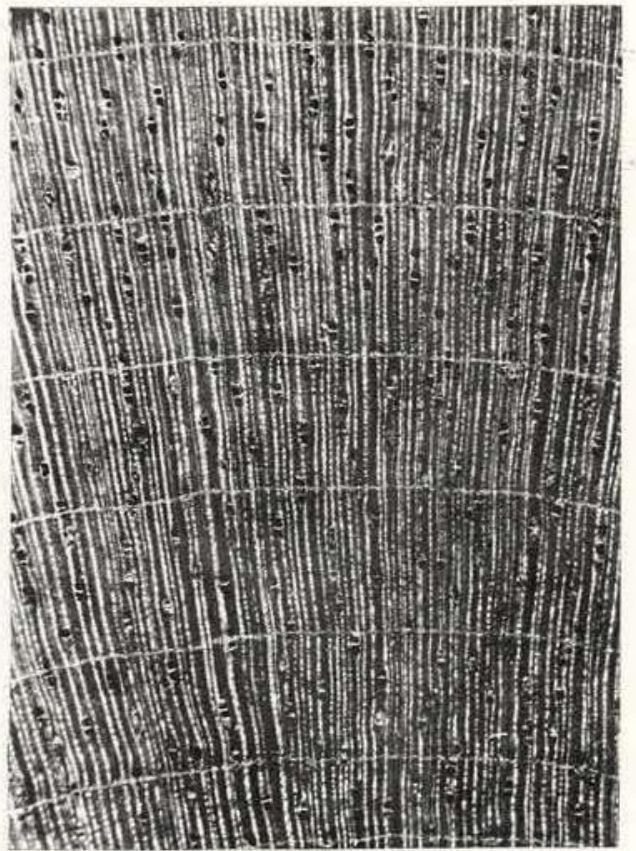

Foto 62 - Iryanthera paraensis

\section{UCUUBARANA}

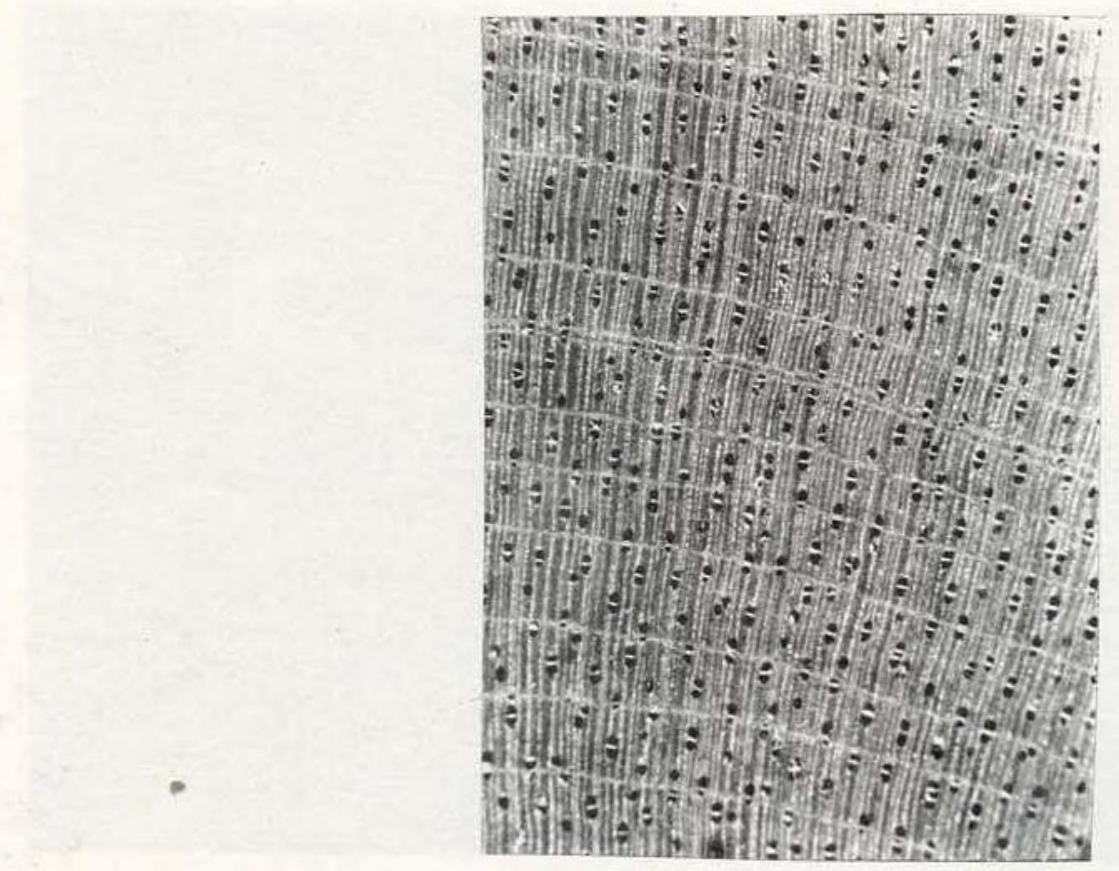

Foto 63 - Iryanthera ulei 
ATLAS DAS MACROFOTOGRAFIAS DA FACE TANGENCIAL EM RELAÇÃO AO EIXO DO TRONCO DE ALGUMAS ESPÉCIES 
Page in blank 
ANGELIM PEDRA

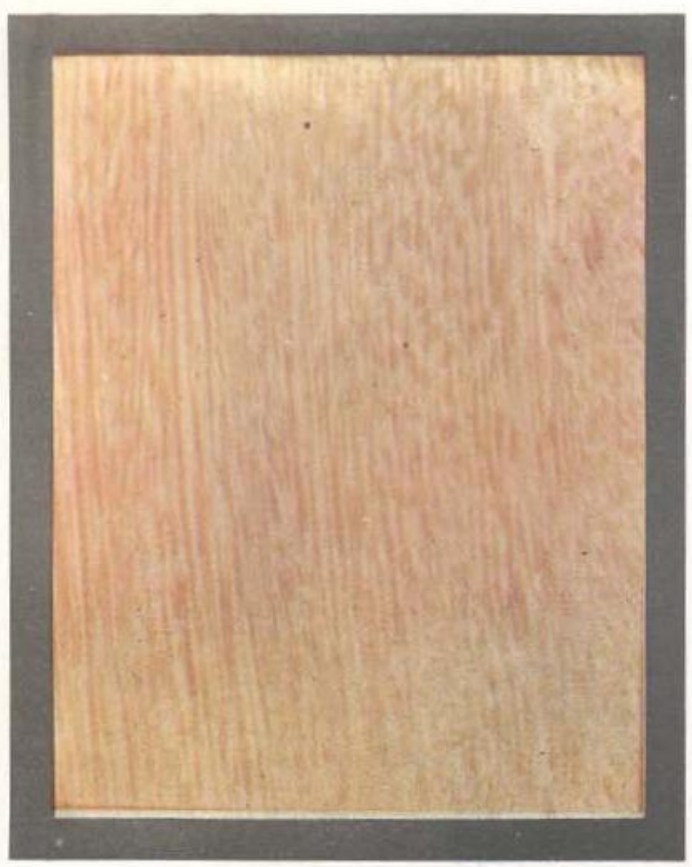

Foto 64 - Hymenolobium petraeum

CEDRINHO

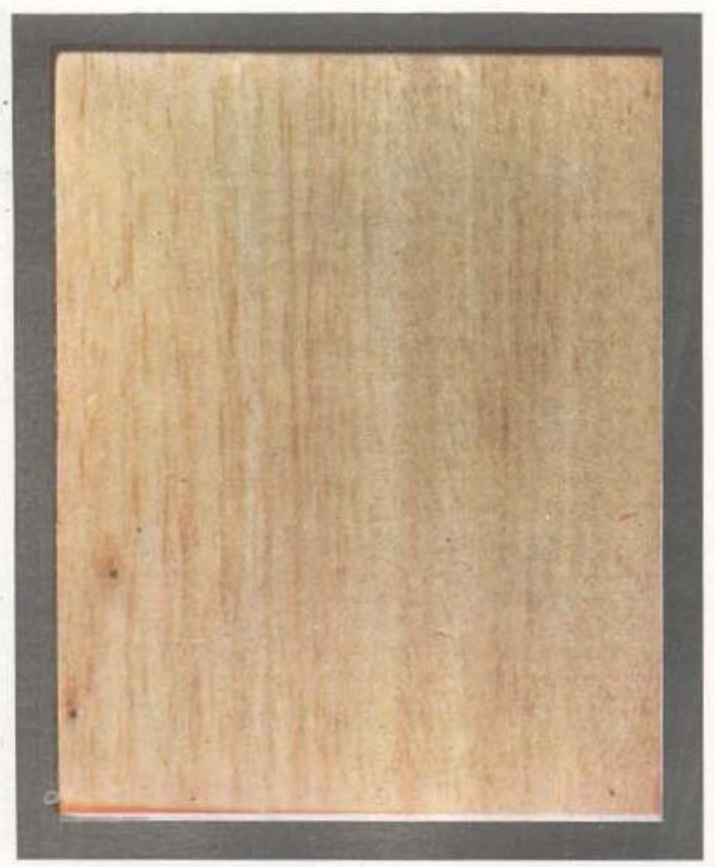

Foto 66 - Cedrela fissilis
BURRA LEITEIRA

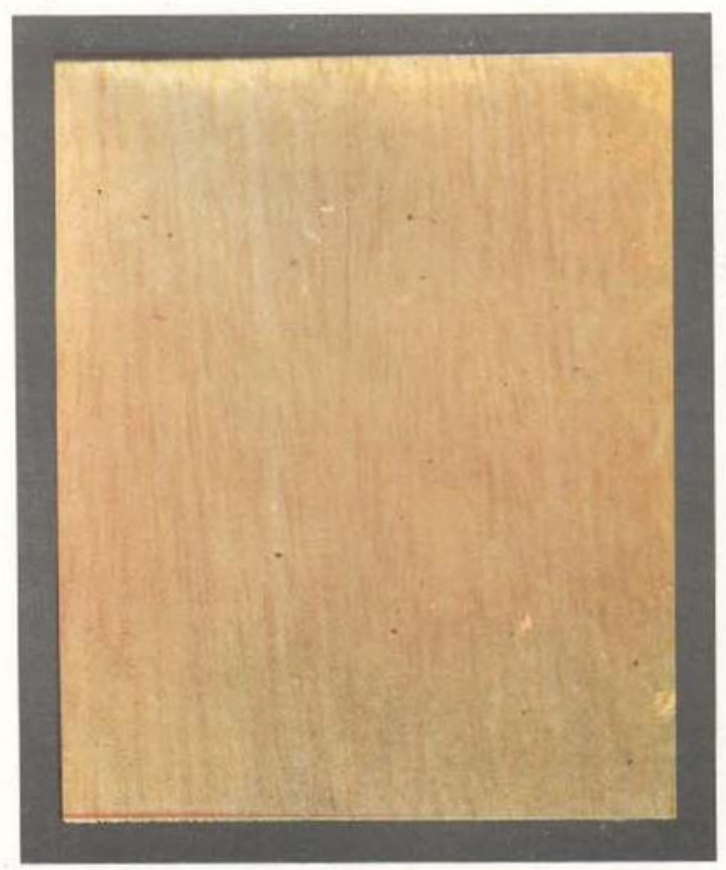

Foto 65 - Bagassa guianensis

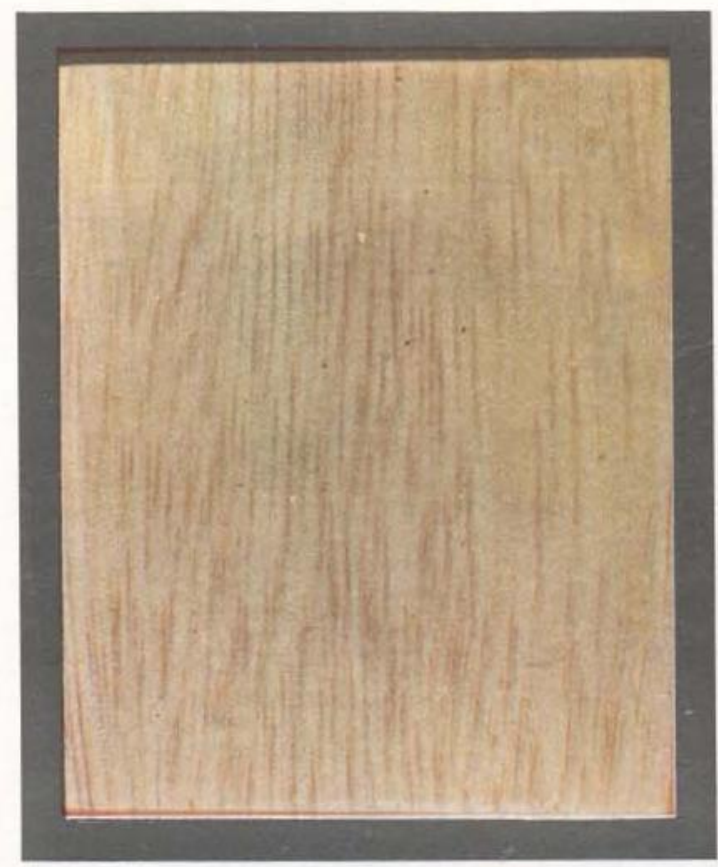

Foto 67 - Cedrelinga catenaeformis 


\section{CEREJEIRA}

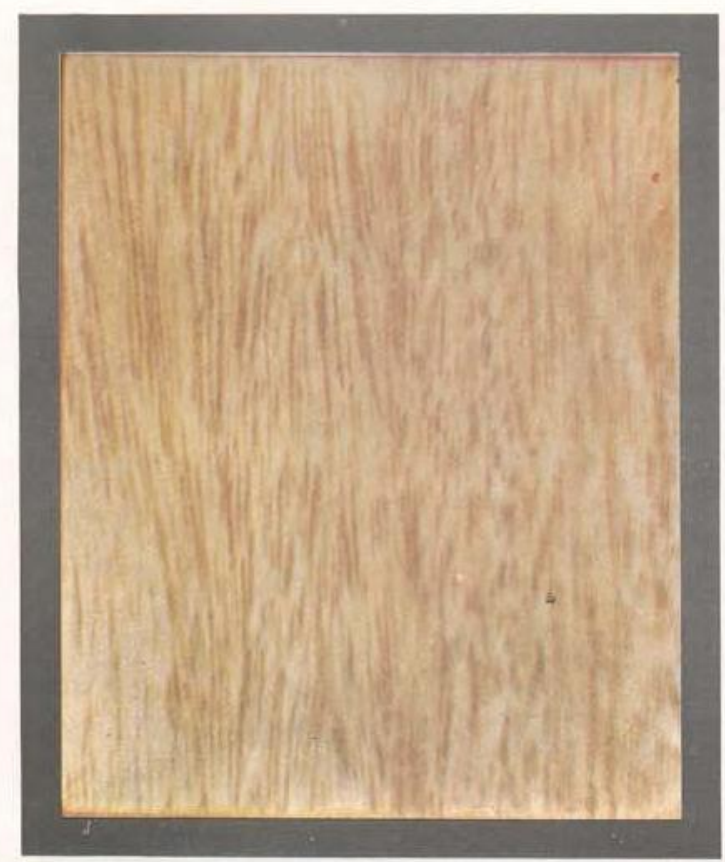

Foto 68 - Torresia acreana

CUPIUBA

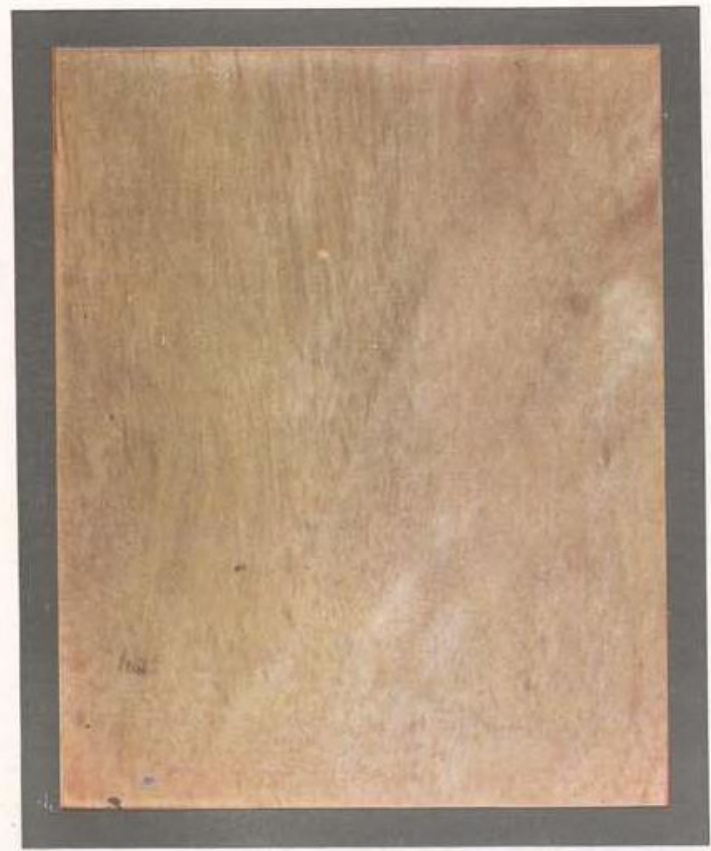

Foto 70 - Goupia glabra
COPAFBA

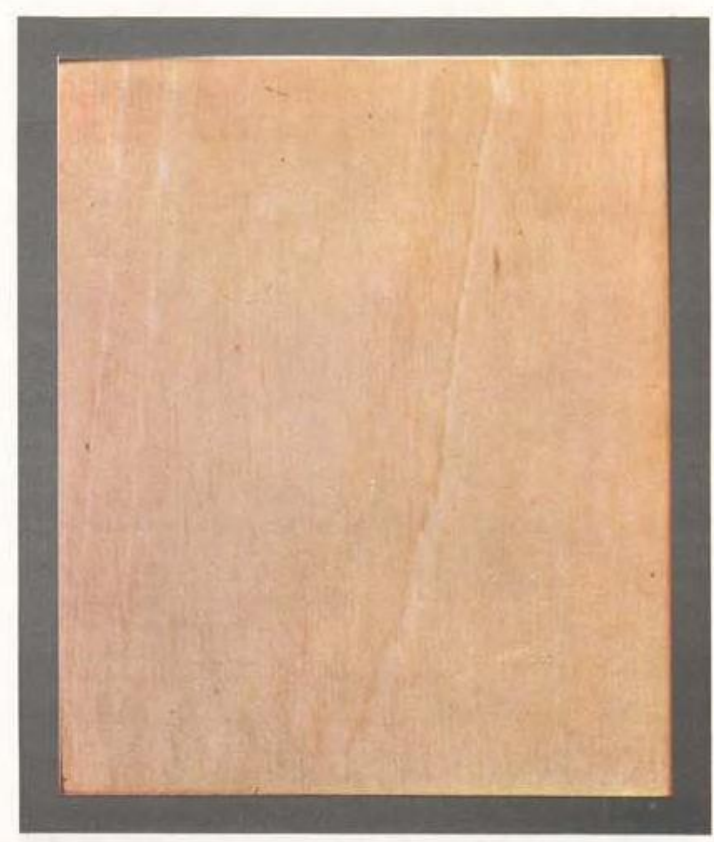

Foto 69 - Copaifera multijuga

FAVEIRA

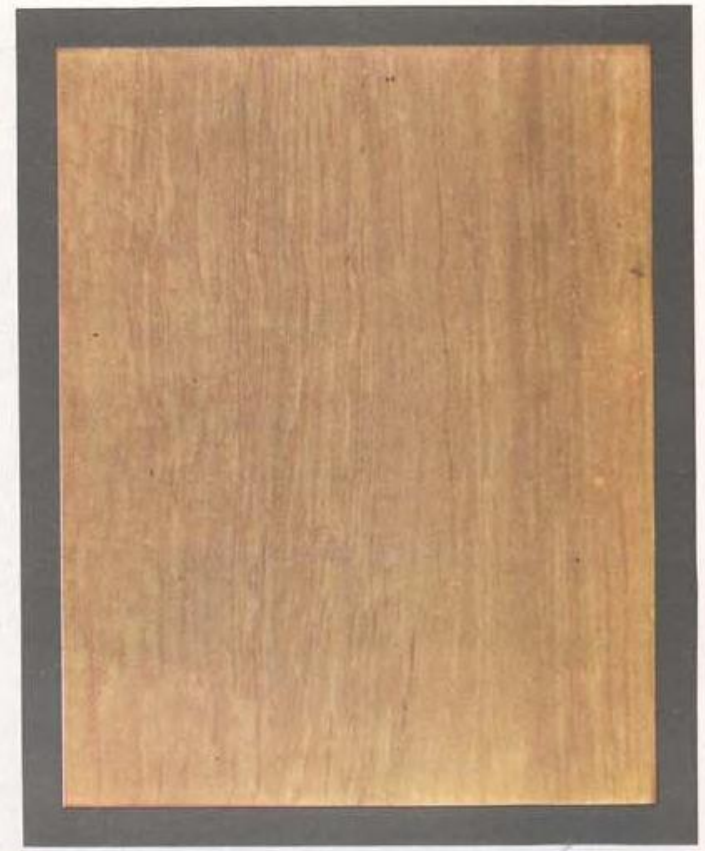

Foto 71 - Vatairea guianensis 
GONĢALO ALVES

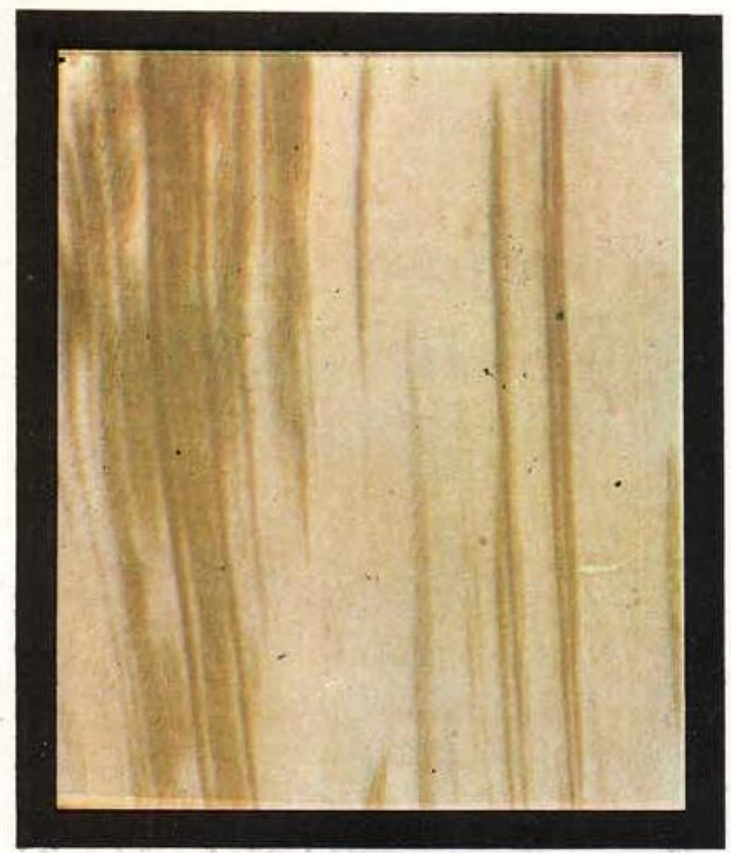

Foto 72 - Astronium fraxinifolium

ITAƯBA

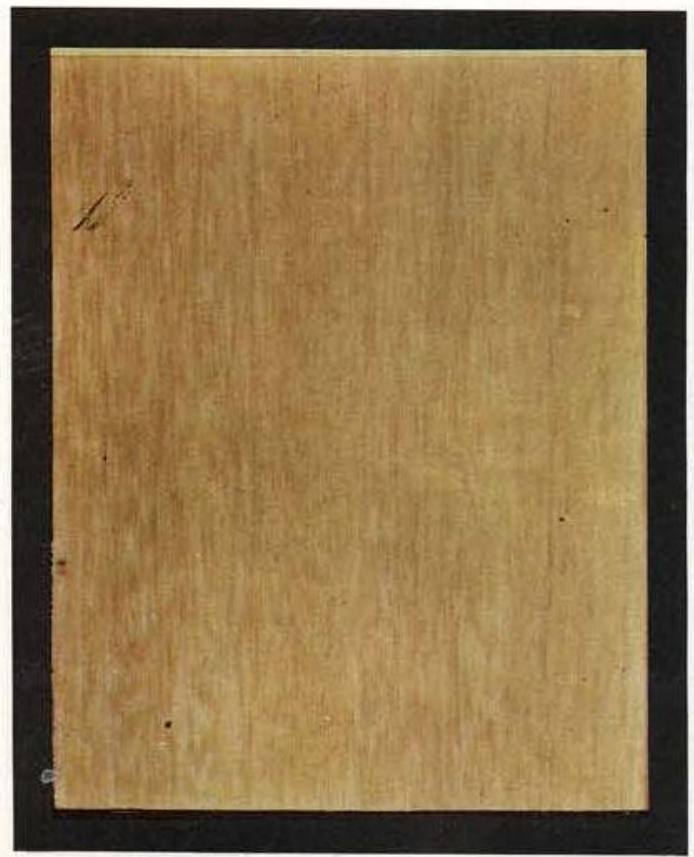

Foto 74 - Mezilaurus itauba
GUARIÚBA

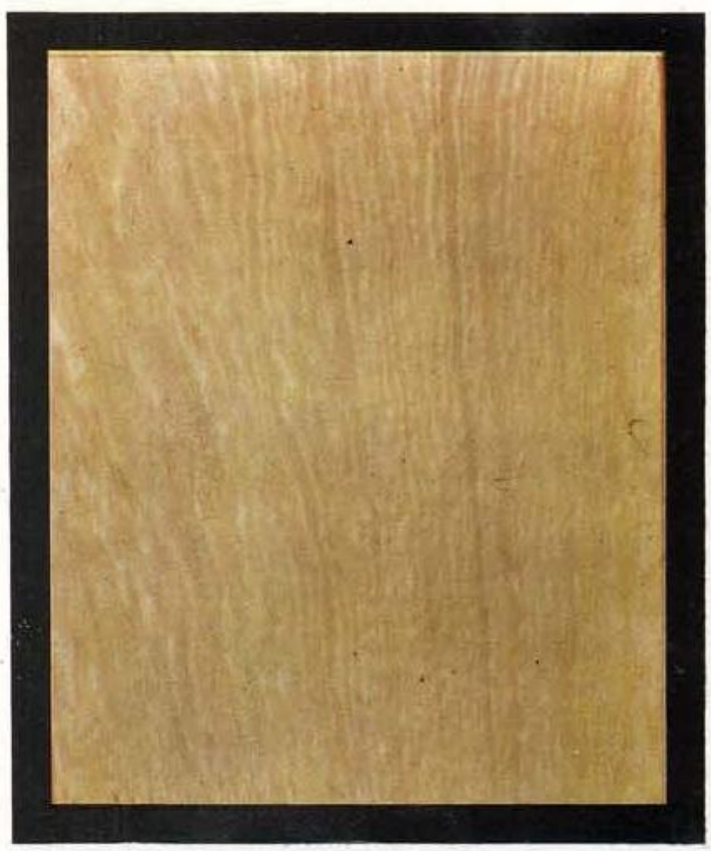

Foto 73 - Clarisia racemosa

JATOBA

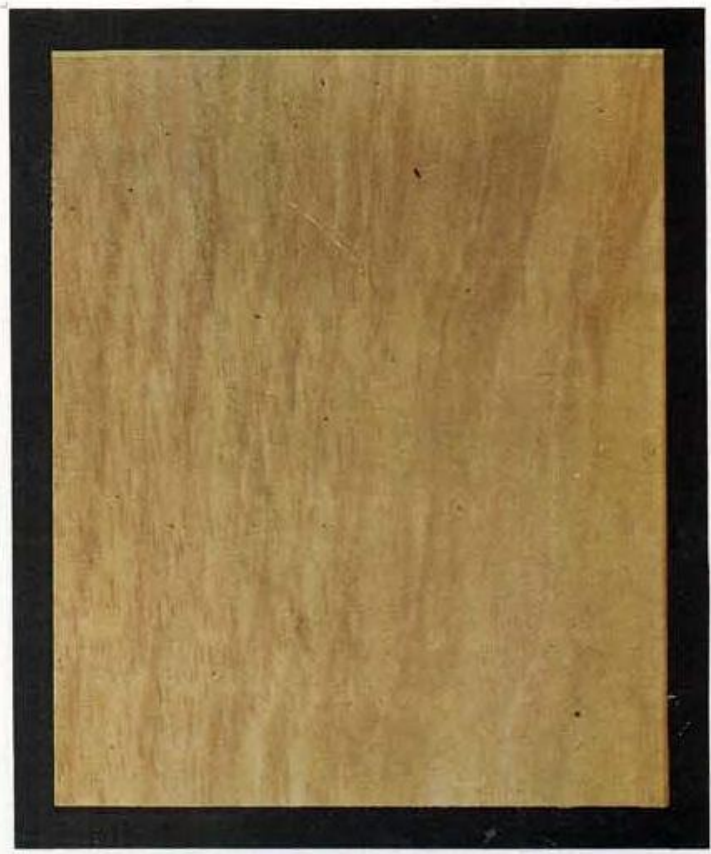

Foto 75 - Hymenaea courbaril 
LACRE

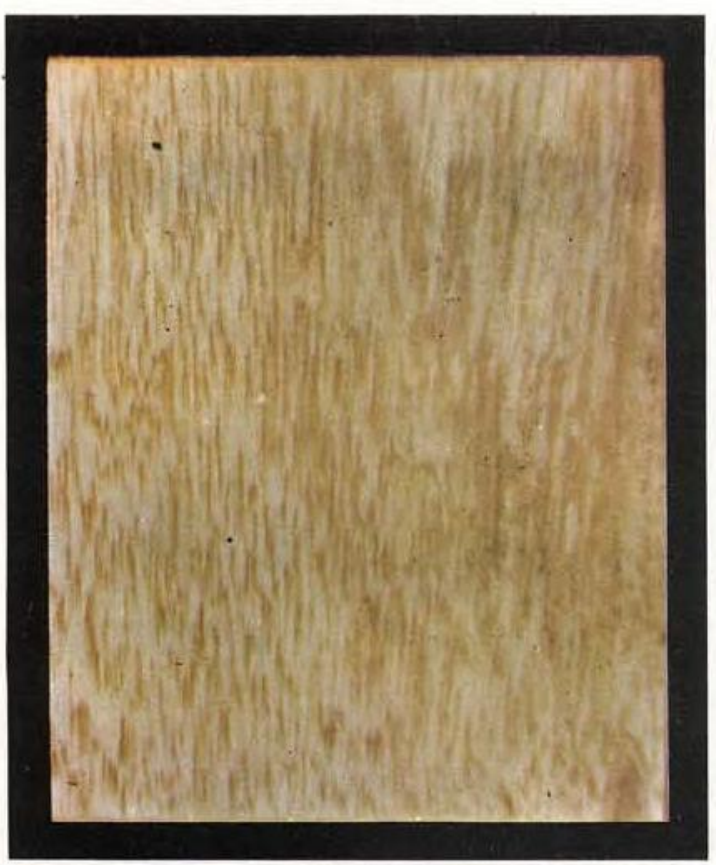

Foto 76 - Vochysia maxima

MAÇARANDUBA BRANCA

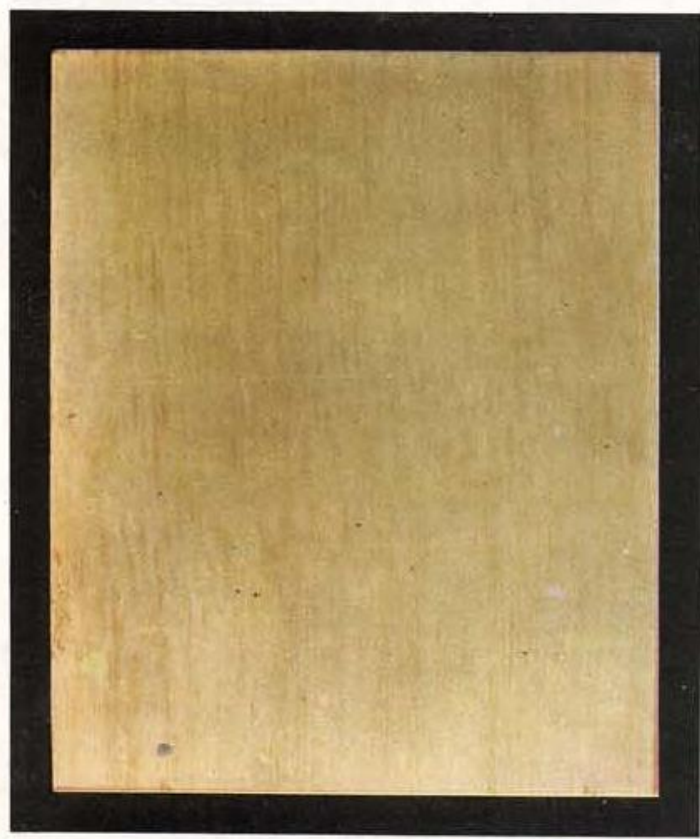

Foto 78 - Virola calophylla
MACCARANDUBA

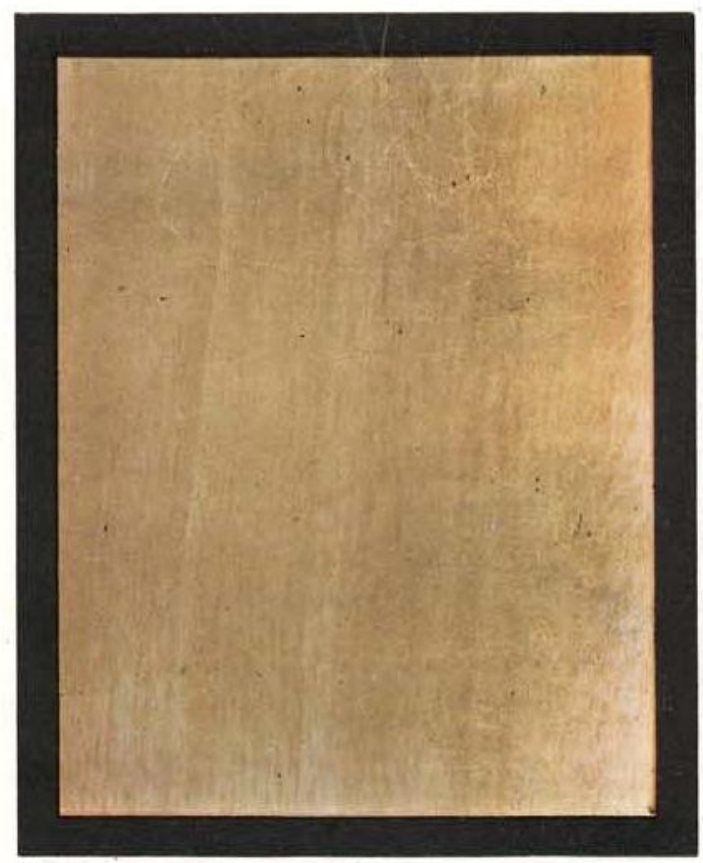

Foto 77 - Manilkara huberi

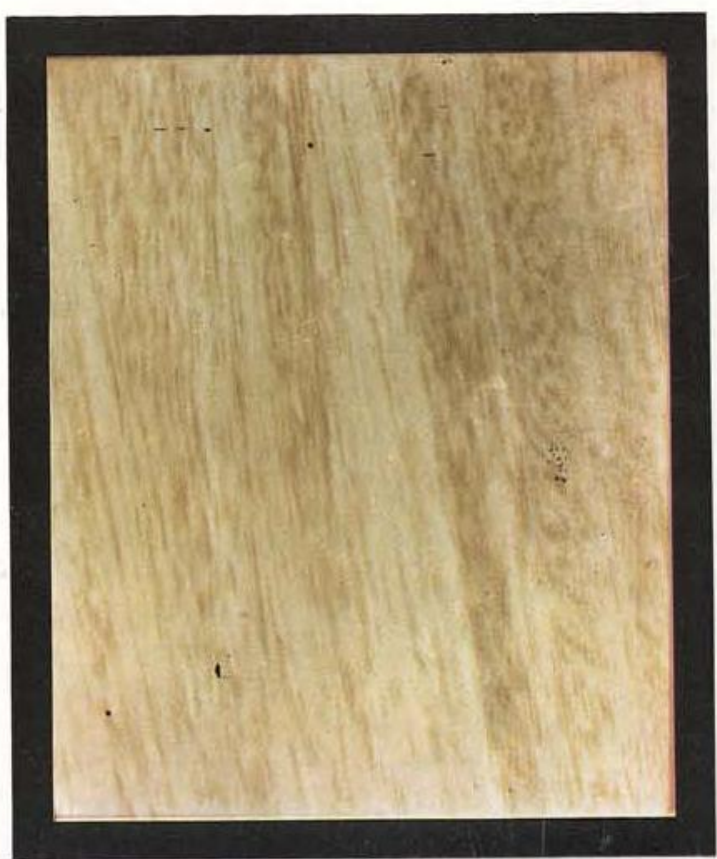

Foto 79 - Swietenia macrophylla 
MOROTOTó

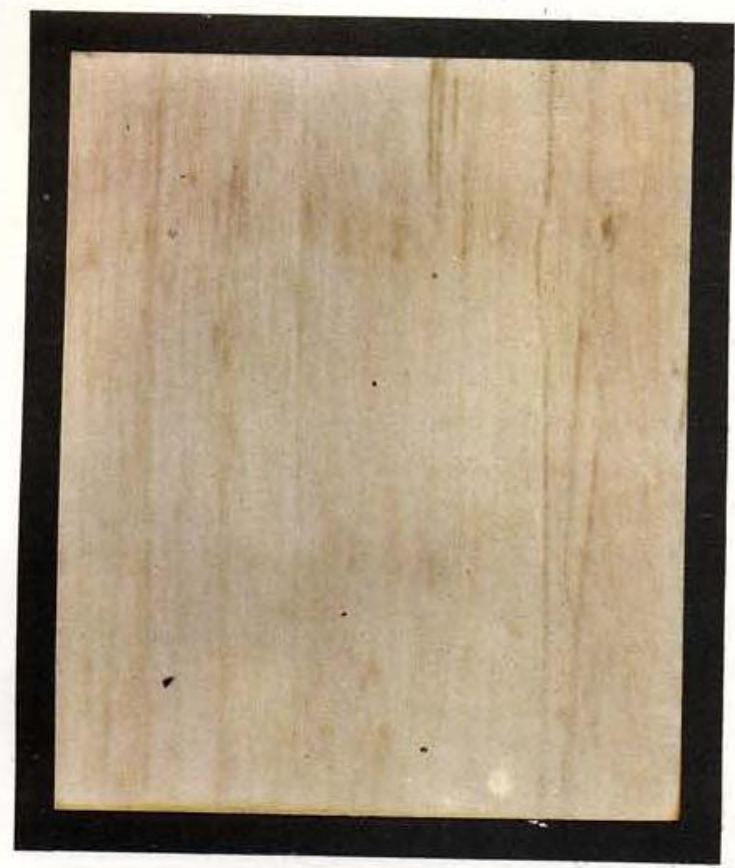

Foto 80 - Didymopanax morototoni

MULATEIRO

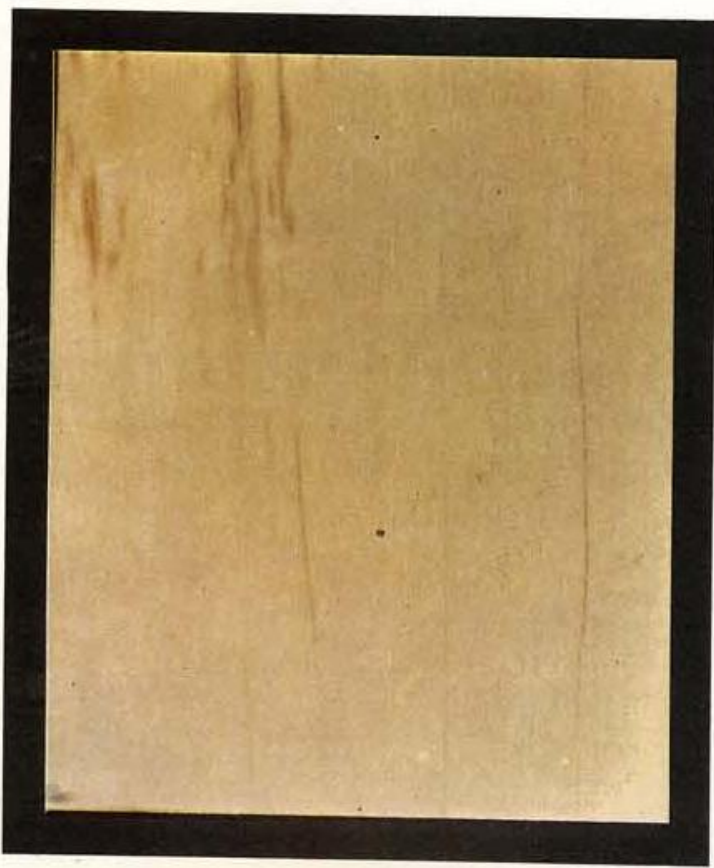

Foto 82 - Calycophyllum acreanum
MUIRAJIBOIA

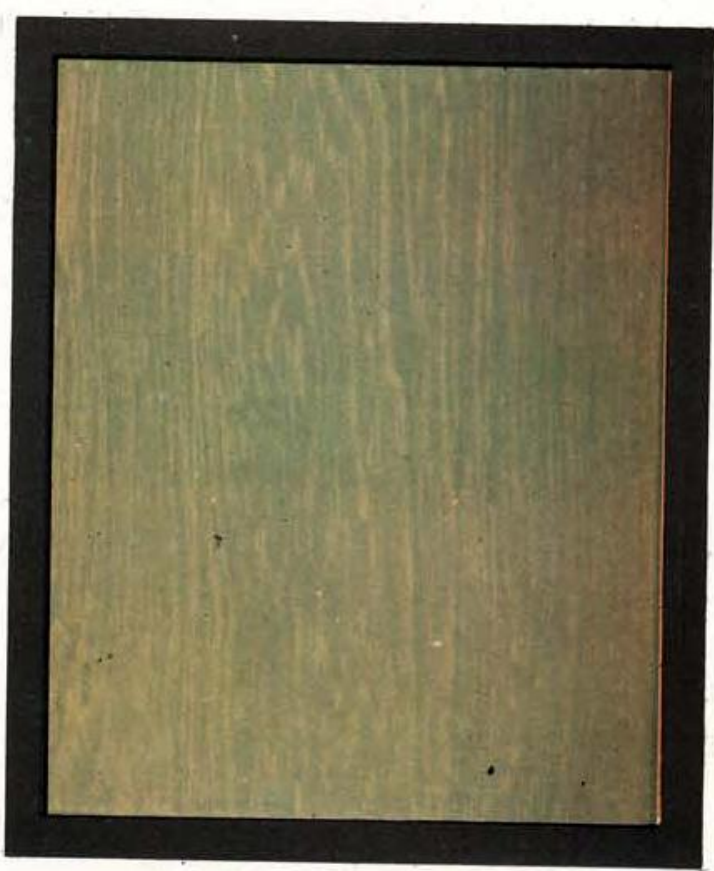

Foto 81 - Swartzia recurva

PAU ROXO

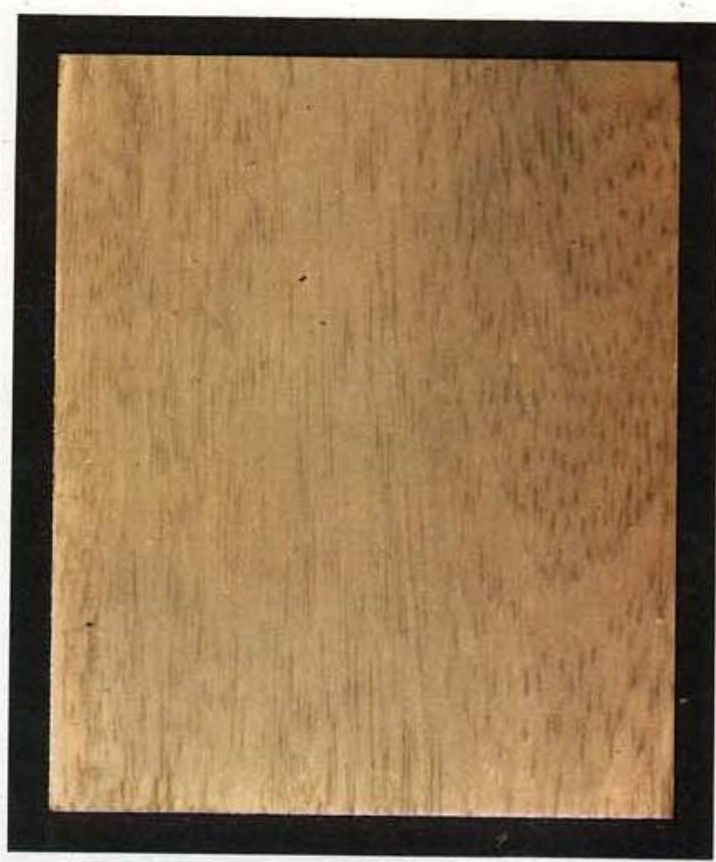

Foto 83 - Peltogyne lecointei 
PEROBA

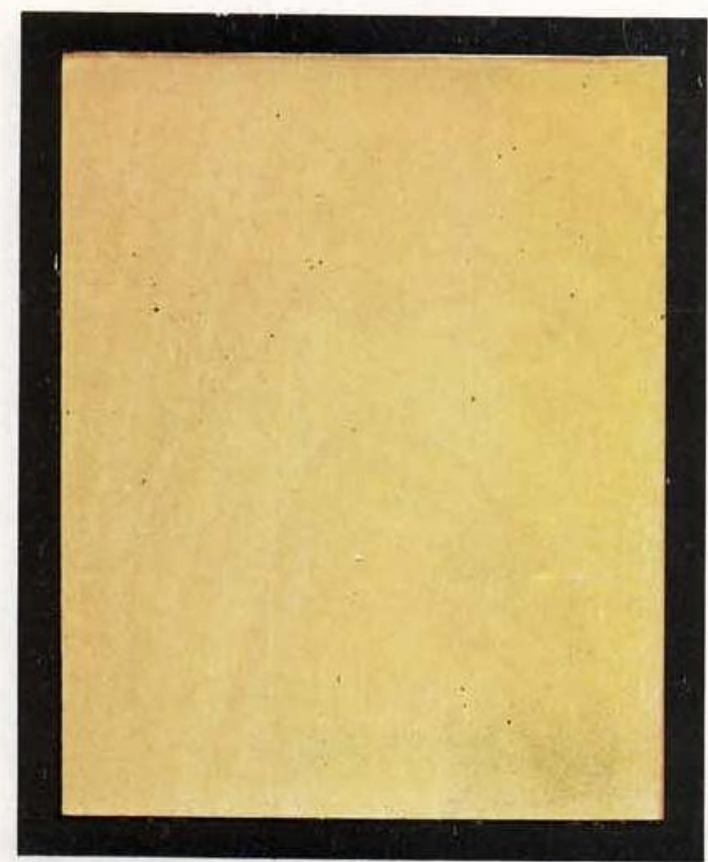

Foto 84 - Aspidosperma polyneuron

RAINHA

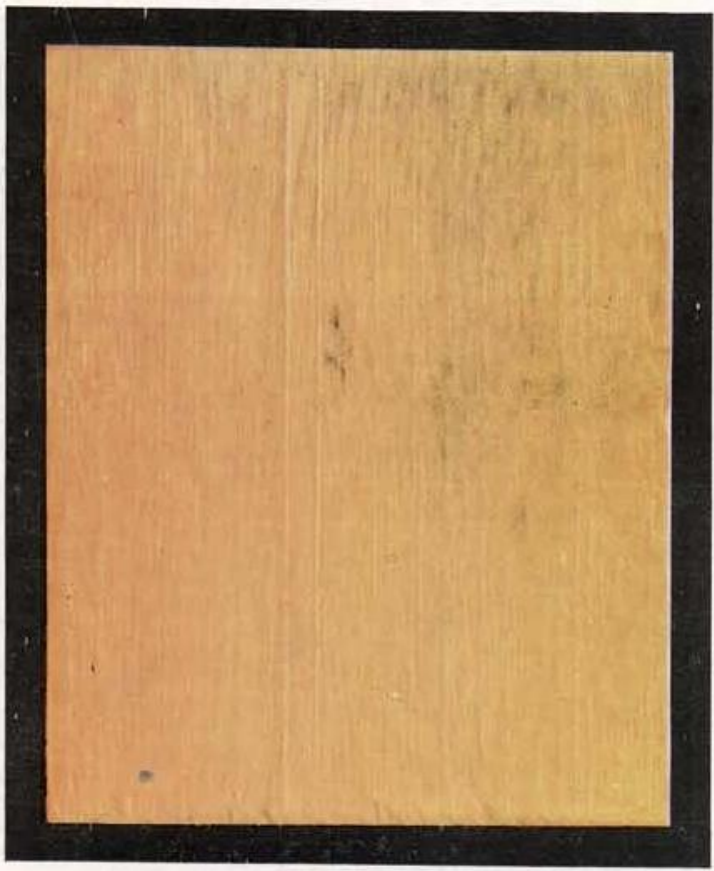

Foto 86 - Brosimum rubescens
PIQUIARANA

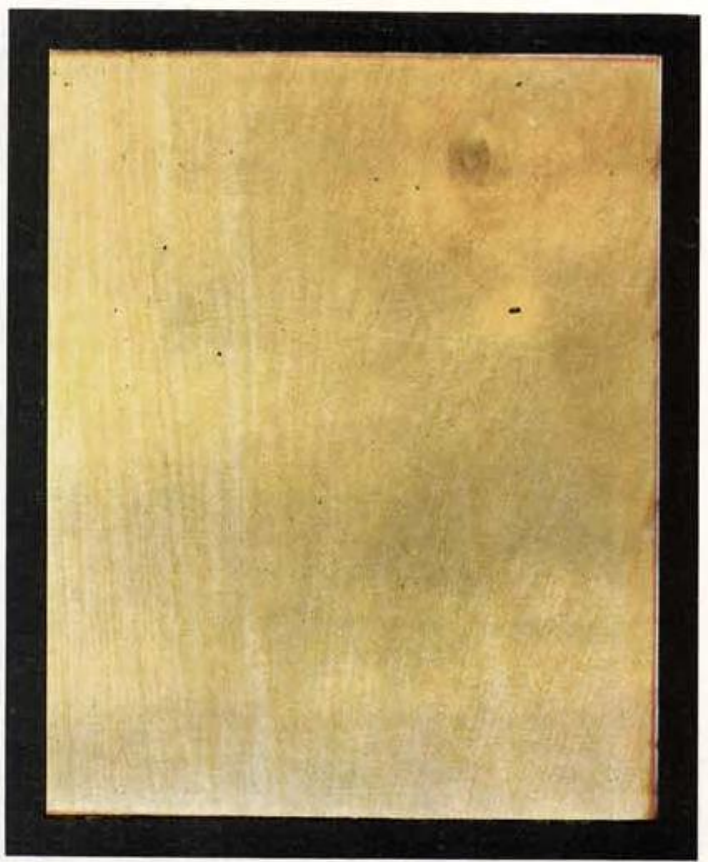

Foto 85 - Caryocar glabrum

\section{TABINHEIRO}

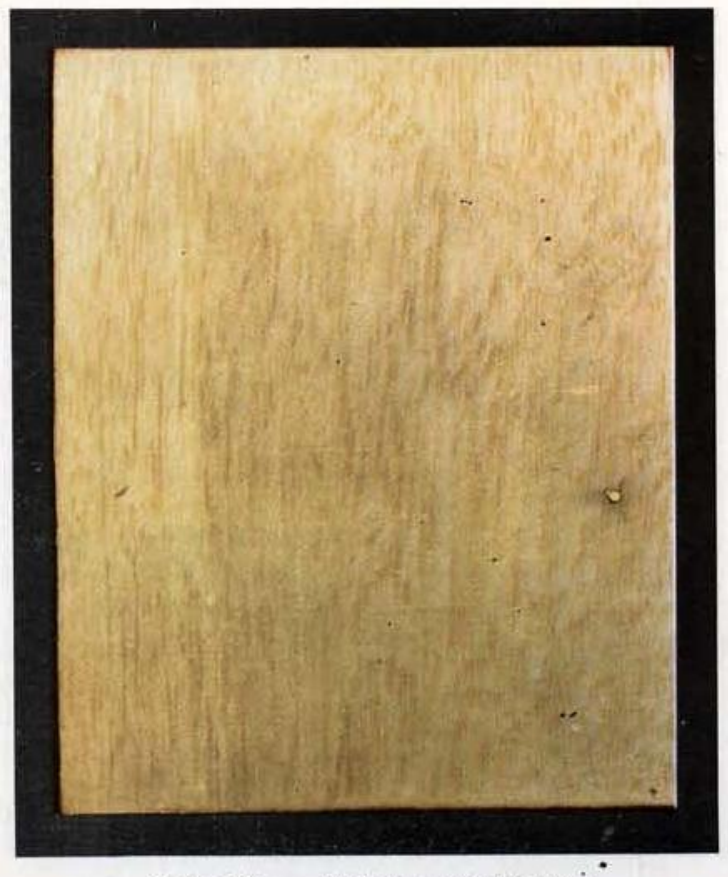

Foto 87 - Erisma uncinatum 
ANANI

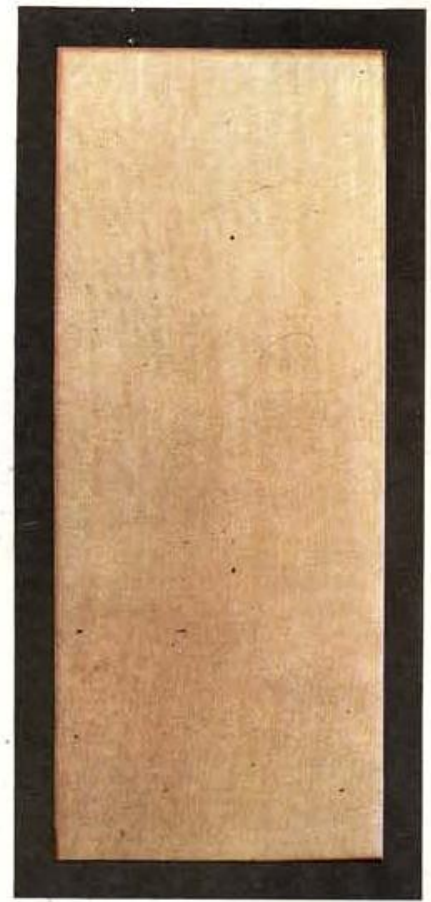

Foto 88 - Symphonia globulifera

JAGAREƯBA

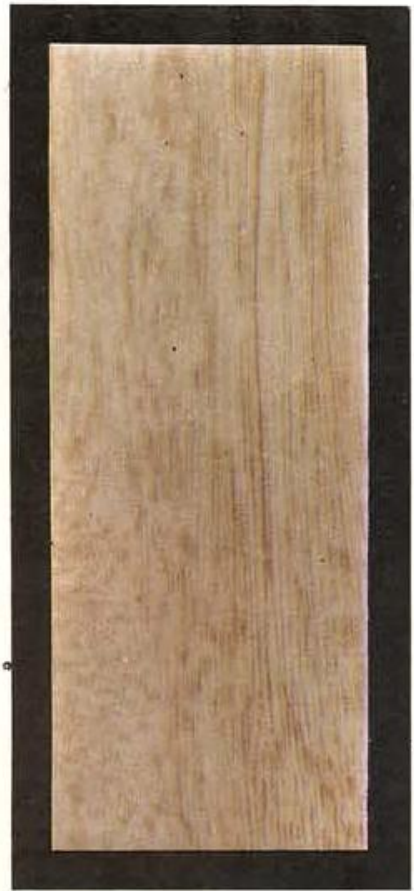

Foto 90 - Calophyllum brasiliense
CASTANHEIRA

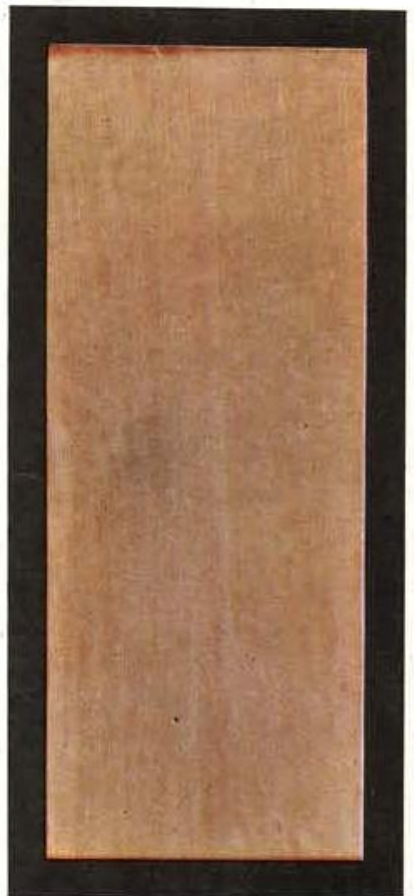

Foto 89 - Bertholletia excelsa

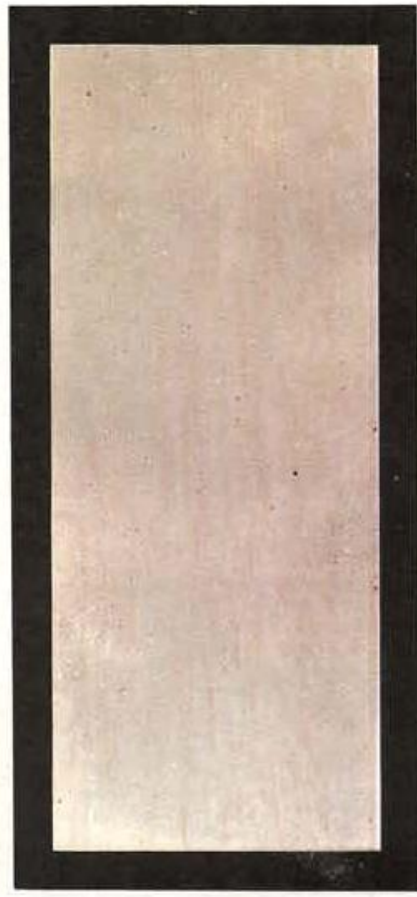

Foto 91 - Simaruba amara 
MUIRATINGA

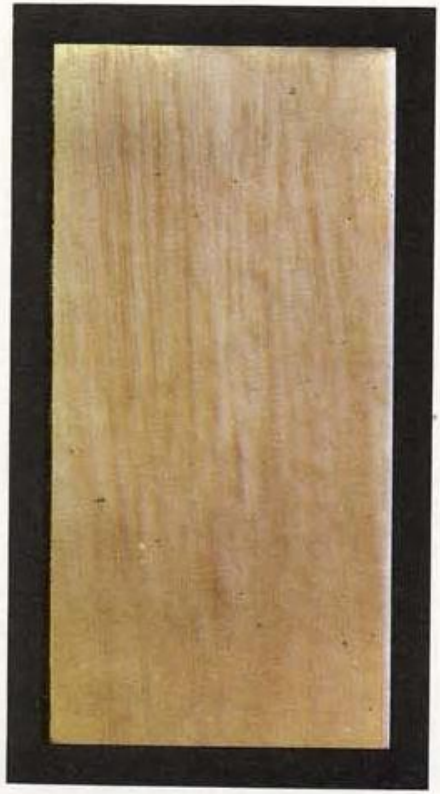

Foto 92 - Maquira coreacea
PARA PARA

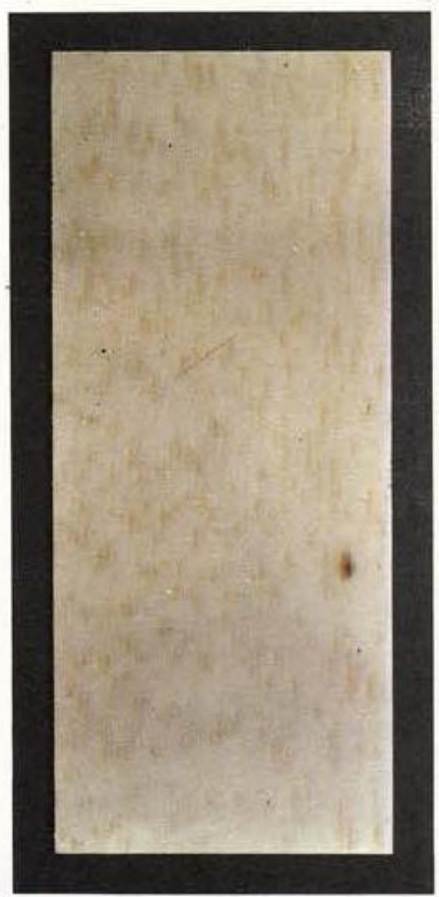

Foto 93 - Jacaranda copaia

PAU D'ARCO

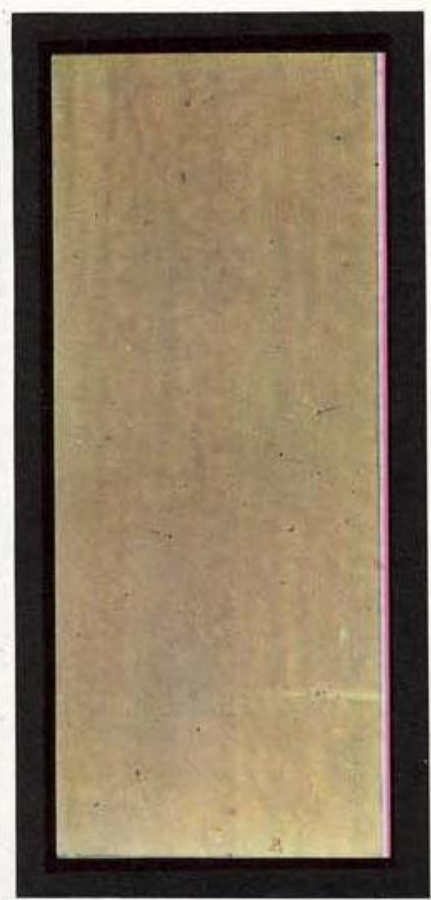

Foto 94 - Tabebuia serratifolia 
The authors present the anatomical macroscopic study of 63 different species of woods. Every one show these indications: cientific and vernacular name, occurrence area habitat, general wood characteristics, macroscopic description, uses, and tables of phisic and mecanic characteristics of some species.

This paper is illustrated by two atlas, one showing the transversal surface photos of the woods on an enlarged scale 10X to facilitate the identification, and the other one showing the tangencial surface to get a vision of the whoie beauty of these woods and axial parallelism of the constituint elements of the wood tissue in relation to axle-trunk. 
ARNAUd, E. \& CORTEZ, R.

1976 - Aripuanã: consideraçōes preliminares. In: Contribuição ao Projeto Aripuanã. Acta Amazonica, 6(4) Supl. 11-31.

AsSociação Brasileira de Normas TÉcnicas (ABNT)

1973 - Descrição de caracteres gerais e anatômicos das madeiras de dicotiledoneas brasileiras. Rio de Janeiro. $18 \mathrm{p}$. (mimeografado).

BERG, C.C.

1972 - Olmedia, Brosimeae (Moraceae). Flora Neotropica. New York, 7:206 p.

BRASIL, D.N.P.M., PROJETO RADAM

1974 - Estudos e levantamentos de recursos naturais. Área Programa Aripuanã. Relatório Final.

Brasil, instituto de pesquisas tecnológicas

1976 - Fichas de características das madeiras brasileiras. São Paulo, pag. $\mathbf{s} / \mathrm{n}$. $^{\circ}$.

Brasil, M.P.C.G., Projeto Aripuanã

1973 - Projeto Aripuanã - Instituto de Planejamento Econômico e Social (IPEA), 96 p., 6 mapas.

BROTERO, F.A.

1956 - Tabelas de resultados obtidos para madeiras nacionais. Instituto de Pesquisas Tecnológicos de São Paulo. 2. ${ }^{a}$ ed1ção. $60 \mathrm{p}$.

Chimelo, J.P.; Matnieri, C.; Naluz, M.A.R. \& PESSOA, A.L.

1976 - Madeiras do Município de Aripuanã, Estado de Mato Grosso. I. Caracterização anatomica e aplicação. In: Contribuiçōes so Projeto Aripuanã. Acta Amazonica, 6(4) : 95-106.

DUCKE, A.

1949 - Notas sobre a Flora Neotropica - II. As Leguminosas da Amazônia Brasile1ra (2. ${ }^{\text {a }}$ ed.). Bol. Tec. IAN, $18: 248 \mathrm{p}$.

1959 - Notas adicionais às Leguminosas da Amazônia Brasileira (Bol. Tec. 18). Bol. Tec. IAN, $36: 45-46$.

Hess, R.W.; Wangand, F.F. \& Dickinson, F.E.

1950 - Properties and uses of Tropical Wood. II. Tropical Woods. Yale Univ., 97 : $132 \mathrm{p}$.

JANE, F.W.

1956 - The Structure of Wood. Adam \& Charles Black. London; $115 \mathrm{p}$.
LE COINTE, $\mathrm{P}$.

1947 - Árvores e Plantas Ôteis (indígenas e aclimadas). Amazônią Brasileira III. 2. ed. Brasiliana, 5 (251).

LisbôA, P.L.B.; Prance, G.T. \& LisbôA, R.C.L.

1976 - Contribuição ao conhecimento da flora do Aripuanã (Mato Grosso). I. Fanerógamas. In: Contribuições ao Projeto Aripuanã. Acta Amazonica, 6(4) : Supl., 33-41.

LisBôA, R.C.L. \& LisBôA, P.L.B.

1978 - Contribuição ao conhecimento da flora do Aripuanã (Mato Grosso) II. Musci. Acta Amazonica (no prelo).

LOUREIro, A.A.

1970 - Contribuição ao estuđo anatômico da madeira de Anonaceas da Amazônia II - Bocageopsis multiflora (Mart.) R. E. Fries, Guatteria scytophylla Diels, Xylopia benthami R.E. Fries e Guatteria olivacea R.E. Fries. Inst. Nac. Pesq. Amaz. (INPA). Manaus. Pesq. Flor., 15. $10 \mathrm{p}$.

1971 - Contribuição ao estudo anatômico da espécie Dialium guianense (Aubl.) Sandw. (Leguminosae). Acta Amazonica. Belém, 1(3) : 85-87.

Loureiro, A.A. \& SILVA, M.F. DA

1968 - Catálogo das madeiras da Amazônia Belém. SUDAM. Vol, 1 e $2: 844 \mathrm{p}$.

1972 - Contribuição ao estudo denđrológico de 5 Parkias (Leguminosae) da Amazônia. Acta Amazonica. Belém, 2(2) : 71-85.

1973 - Contribuição. ao estudo dendrológico de 5 Leguminosae da Amazônia. Acta Amazonica. Belém, 3(2) : 17-31.

LOUREIro, A.A. \& Rodrigues, W.A.

1975 - Estudo anatômico da madeira do gênero Swartzia (Leguminosae) da Amazônia - I. Acta Amazonica. Belém, 5(1): 79-86.

Loureiro, A.A.; Silva, M.F. da \& Alencar, J. Da C. 1978 - Essências madeireiras da Amazônia (no prelo).

MAINIERI, C.

1962 - Madeiras leves da Amazônia empregadas em caixotaria. Estudo Anatômico macro e microscópico. Inst. Pesq. Tecn. São Paulo. Publ. 686, 39 p. 
1971 - 25 madeiras da Amazônia de valor comercial, caracterização macroscópica, usos comuns e índices qualificativos. Inst. Pesq. Tecn. São Paulo. $29 \mathrm{p}$.

Mainieri, C. \& Loureiro, A.A.

1964 - Madeiras de Symphonia globulifera L., Platonia insignis Mart., Moronobea coccinea Aubl. e Moronobea pulchra Ducke. Estudo Anatômico macro e microscópico como contribuição para a sua identificação. Inst. Nac. Pesq. Amaz. Manaus. Botânica, 18:28 p.

Mainieri, C. \& Pereira, J.A.

1958 - Identificação das principais madeiras de comércio no Brasil. Inst. Pesq. Tecn. São Paulo. Bol, 46, 189 p.

1965 - Madeiras do Brasil. Sua caracterização macroscópica, usos comuns e índice qualitativos físico e mecânicos. Publ. do Inst. Pesq. Teen. São Faulo. Sep. do Anuário Bras. de Econ. Flor., 17 : 282 p.

MAtros Filho, A. DE

1954 - Anatomia do lenho do gênero Peltogyne Vog. Arg. Serv. Flor., RJ., 8:146 p.

Pereira, A.J. DO R.; VAsconcellos, J.M.C. DE; TAvares, S. \& Tavares, E.

1970 - Caracteres Tecnológicos de 25, espécies de madeiras do Nordeste do Brasil. Bol. Rec. Nat. SUDENE/DRN, $8:$ 5-148.

Prance, G.T. \& Silva, M.F. DA

1973 - Caryocaraceae. Flora Neotropica. New York, 12: $75 \mathrm{p}$.

Projeto de DesenVolvimento E Pesquisas Florestais (PRODEPEF)

1976 - Centro de Pesquisas Florestais da Amazônia. Programação Técnica. Brasília, 45(9): $59 \mathrm{p}$.

RECORD, S.J. \& HESS, R.W.

1949 - Timbers of the New World. New Haven. Yale Univ. Press. $640 \mathrm{p}$

RIZZINI, C.T.

1971 - Árvores e madeiras útreis do Brasil Manual de Dentrológia Brasileira. Ed Edgard Blücher. São Paulo. 249 p.

SADDI, N

1977 - Primeira contribuição sobre a flora de Humboldt (Aripuanã, Mato Grosso).
Trabalhos do XXVI Congresso Nacional de Botânica. Academia Brasileira de Ciências, RJ.: 519-568.

SILVA, M.F. DA

1976 - Revisão Taxonomica do gênero Pelto. gyne Vog. (Leguminosae). Acta Amazonica. Belém, 4(1):61 p. (Suplemento)

SiLVA, M.F. DA; LisbôA, P.L.B. \& LisBôA, R.C.L.

1977 - Nomes vulgares de Plantas Amazônicas. INPA, Nianaus: $222 \mathrm{p}$.

SUPERINTENDÊDCIA DO DESENVOLVIMENTO DA AMAZÔNIA (SUDAM)

1969 - Ensaios sistemáticos no campo da Tecnologia de madeiras. Dept. de Rec. Nat. Amazôña. Belém : $45 \mathrm{p}$.

VAN DER SLOOTEN

1976 - Espécies florestais da Amazônia - Características, propriedades e dados de engenharia da madeira. Proj. Des. Flor. Brasília, 6. Ser. Tec., $9 \subset \mathrm{p}$.

VAN der Slcoten, H.J.; HARry, C. \& Joel, A.P.

1962 - Características anatômicas y propriedades físico mecânicas de algumas espécies maderables del Brasil. Inst. Flor. Lat. Ameri. Venezuela, $10: 52-81$.

VAN der SLOOTEn, H.J.; Lisboa, C.D.J.; PAstore, JR. \& SOBRAL FILHO, M.

1976 - Forestry development and research. Characteristics, properties and engineering data of sixteen commercial Amazon species. Brasilian Institute for Forestry Development. Brasília, 20:73 p.

VERGUEIRO, F.

1978 - É hora de conhecer melhor nossa madeira. E de faturar. Amazônia, 41: $12-10$.

WANgaARd, F.F. \& MUSChLER, A.

1952 - Properties and uses of Tropical Woods. III. Trop. Woods. Yale Univ., $98: 190$ p.

WANGAARD, F.F.; KoEHLER, A. \& MUSCHLER, A.F. 1954 - Properties and uses of Tropical Woods. Trop. Woods. Yale Univ., 99: $187 \mathrm{p}$.

WANGAARD, F.F.; STERn, W.L. \& GOODRICH, S.L. 1955 - Properties and uses of Tropical Woods, V. Trop. Woods. Yale Univ., 103: 139 p.

(Aceito para publicação em 16/03/79) 


\section{ÍNDICE ALFABÉTICO DOS NOMES VULGARES}

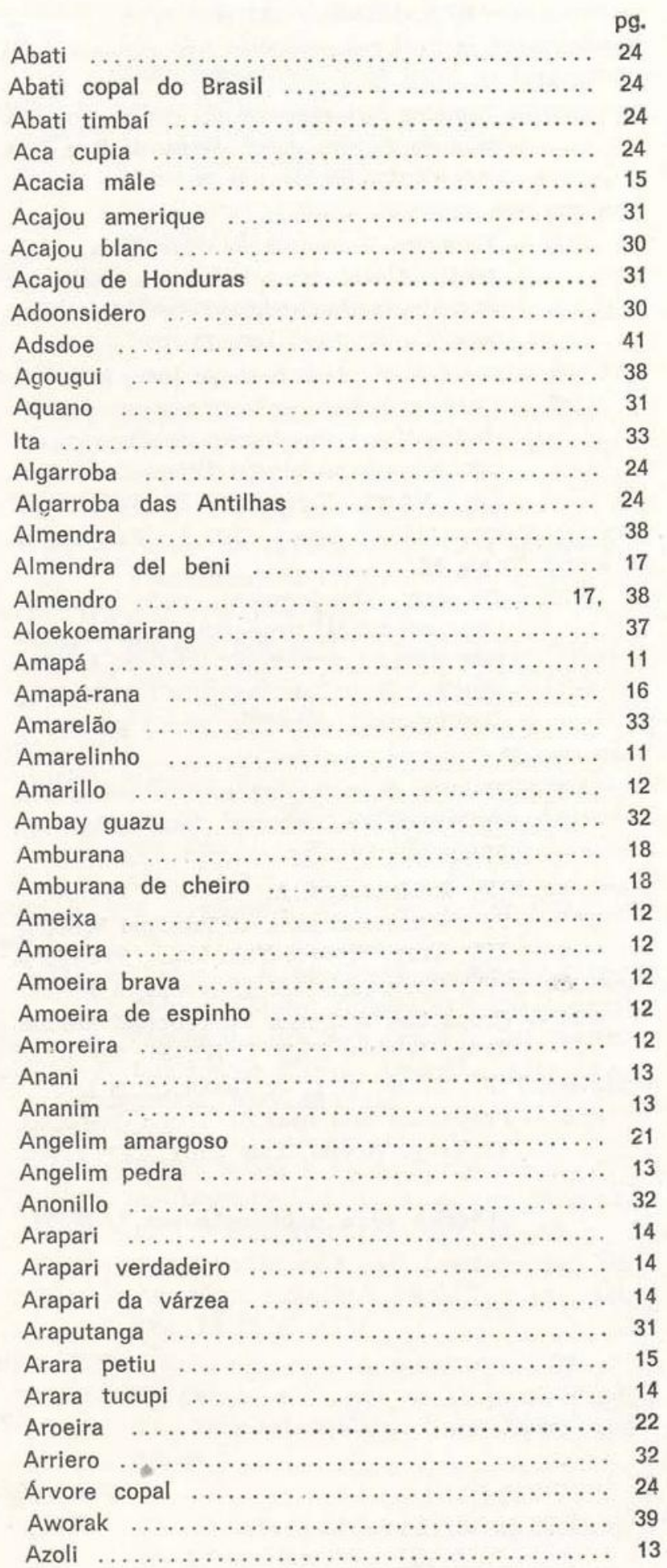

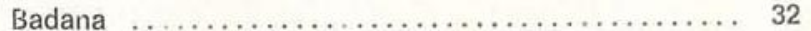

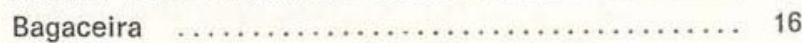

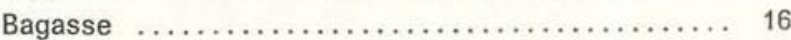

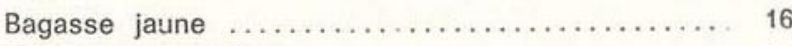

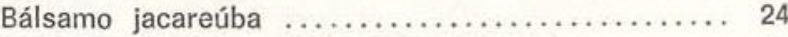

Barillo ............................. 13

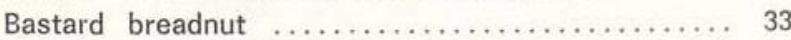

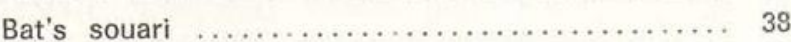

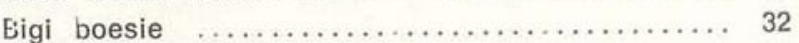

Bigleaf mahogany $\ldots \ldots \ldots \ldots \ldots \ldots \ldots \ldots \ldots \ldots, 31$

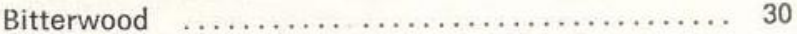

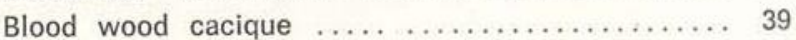

Boarwood ............................... 13

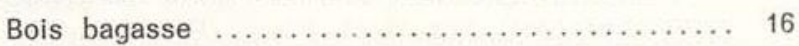

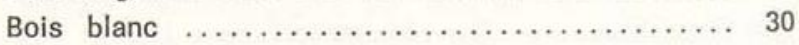

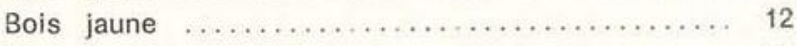

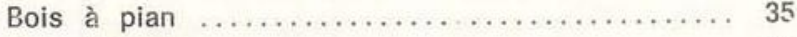

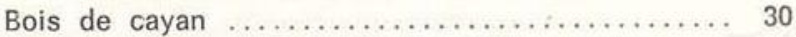

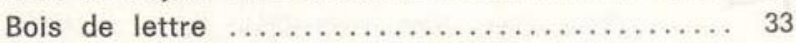

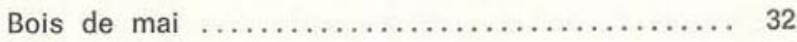

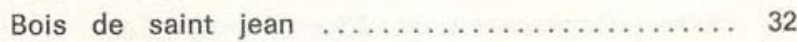

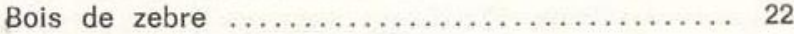

Boloteria .............................. 14

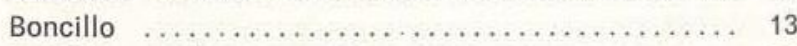

Brasilian mahogany $\ldots \ldots \ldots \ldots \ldots \ldots \ldots \ldots \ldots . \ldots \ldots \ldots \ldots$

Brazilnoot ............................ 17

Brazil nuts .......................... 17

Brazil-nut tree .......................... 17

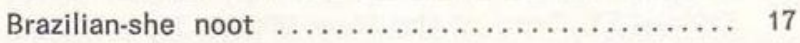

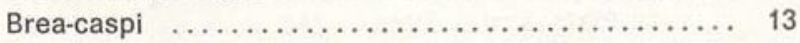

Breu ................................ 15

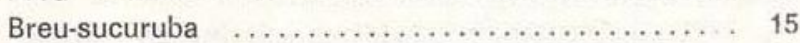

Brick-wax-tree ......................... 13

Broadleaf mahogany $\ldots \ldots \ldots \ldots \ldots \ldots \ldots \ldots \ldots, 31$

Bruto .............................. 41

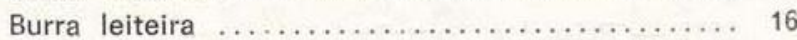

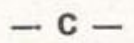

Cabacalli $\ldots \ldots \ldots \ldots \ldots \ldots \ldots \ldots \ldots \ldots \ldots \ldots, 20$

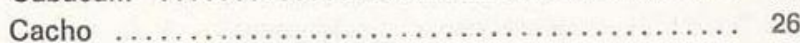

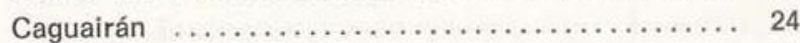

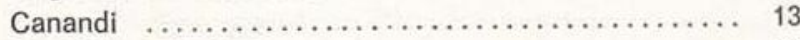

Canuco ................................ 30

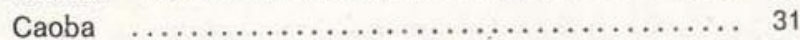

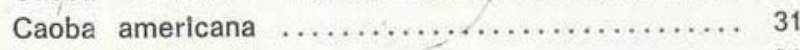

Caoba Hondurenã ....................... 31

Caoba de hoja caduca $\ldots \ldots \ldots \ldots \ldots \ldots \ldots \ldots . . . \ldots \ldots$ 


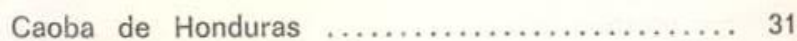

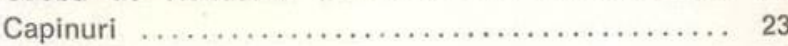

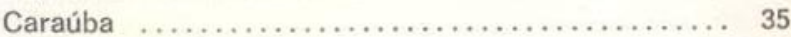

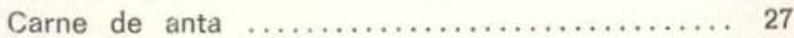

Caroba ................................... 35

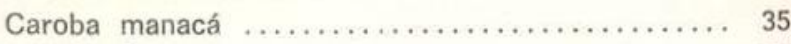

Caroba do mato ......................... 35

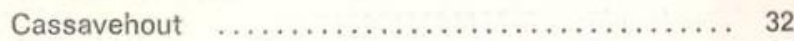

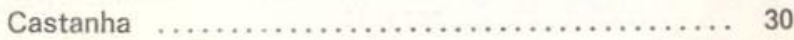

Castanha vermelho $\ldots \ldots \ldots \ldots \ldots \ldots \ldots \ldots \ldots, 30$

Castanha de cotia ........................ 16

Castanha del maranõn .................... 17

Castanha do Brasil ....................... 17

Castanha do Maranhão ................... 17

Castanha do Pará ........................... 17

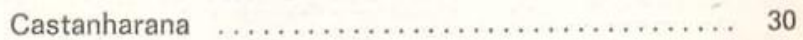

Castanheira .............................. 17

Castano de madre de dios ................. 17

Cataqui-iamani ................................ ${ }^{4}$

Cedrinho .............................. 17

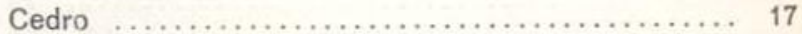

Cedro do pântano ......................... 23

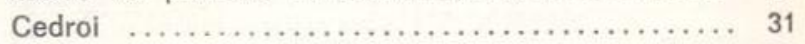

Cedrorana $\ldots \ldots \ldots \ldots \ldots \ldots \ldots \ldots \ldots \ldots \ldots \ldots \ldots \ldots \ldots \ldots, 26,31$

Central american mahogany $\ldots . \ldots \ldots \ldots \ldots . . . \ldots .31$

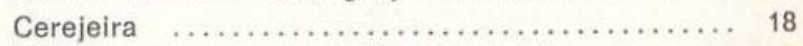

Cerillo .............................. 13

Chacalte ............................... 31

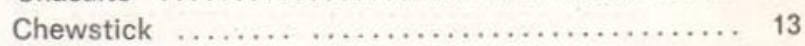

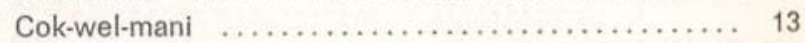

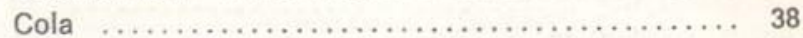

Comenero ........................... 26

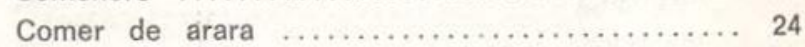

Copaia ............................... 35

Copaia des chanters $\ldots \ldots \ldots \ldots \ldots \ldots \ldots \ldots \ldots, 35$

Copaíba ............................... 19

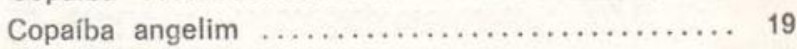

Copaíba mari-mari ....................... 19

Copaiba roxo ......................... 19

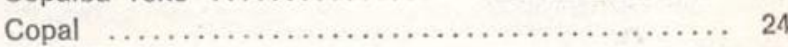

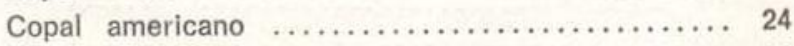

Copal do Brasil .......................... 24

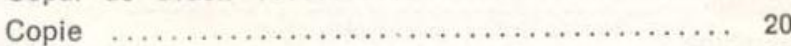

Copinol ................................. 24

Coração de negro ...................... 40

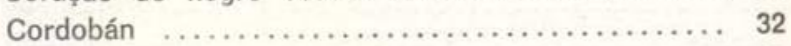

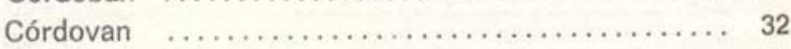

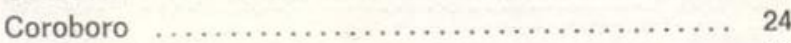

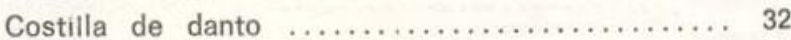

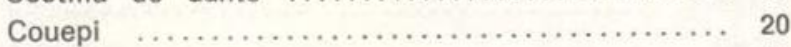

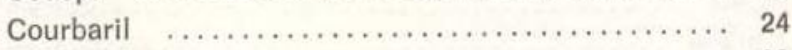

Craíba .................................. 30

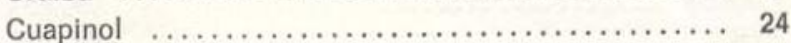

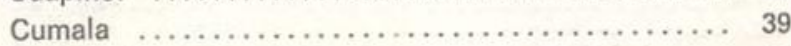

Cumala blanca ........................... 39

Cumaia bolabola ........................... 39

Cumaia roja $\ldots \ldots \ldots \ldots \ldots \ldots \ldots \ldots \ldots \ldots \ldots \ldots, \quad 39$

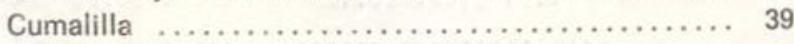

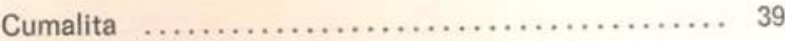

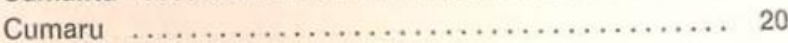

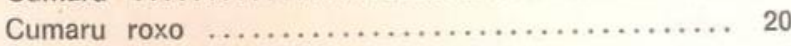

Cumaru verdadeiro $\ldots \ldots \ldots \ldots \ldots \ldots \ldots \ldots \ldots \ldots, 20$

Cumaru da folha grande .................. 20

Cumaru de cheiro ........................ 18

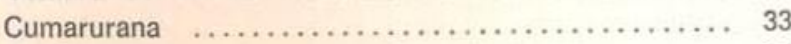

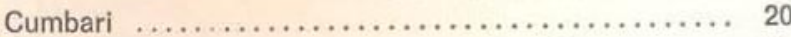

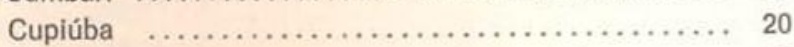

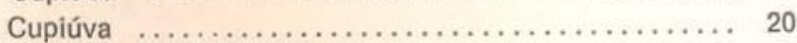

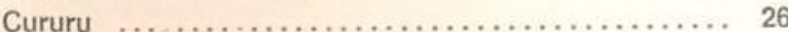

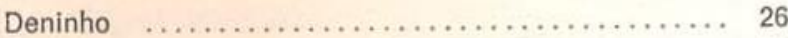

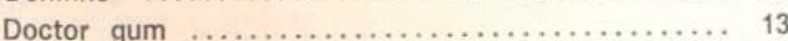

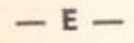

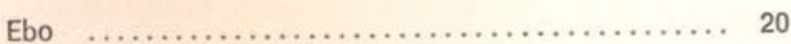

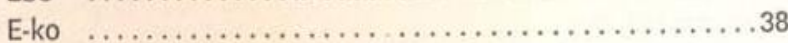

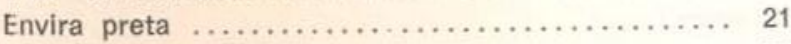

Envira surucucu $\ldots \ldots \ldots \ldots \ldots \ldots \ldots \ldots \ldots \ldots, 21$

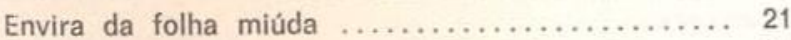

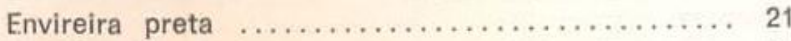

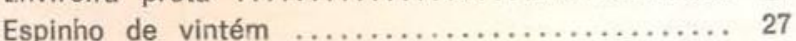

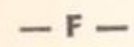

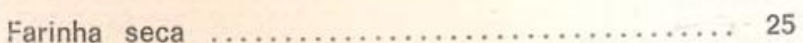

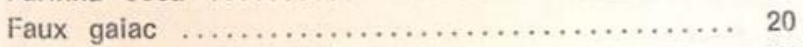

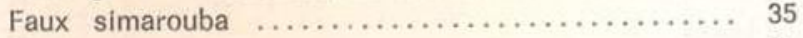

Fava $\ldots \ldots \ldots \ldots \ldots \ldots \ldots \ldots \ldots \ldots \ldots \ldots \ldots \ldots \ldots \ldots \ldots \ldots, 21$

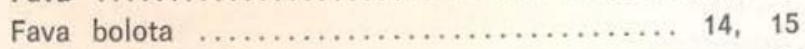

Faveira de berloque $\ldots \ldots \ldots \ldots \ldots \ldots \ldots \ldots \ldots, 15$

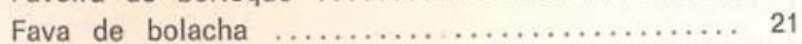

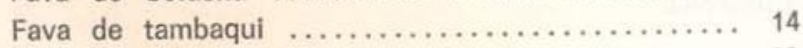

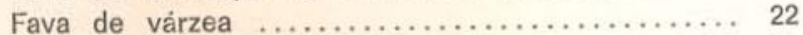

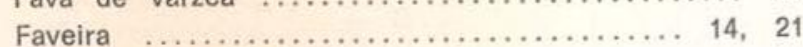

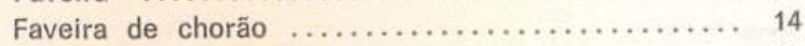

Faveira de empigem $\ldots \ldots \ldots \ldots \ldots \ldots \ldots \ldots \ldots, 21$

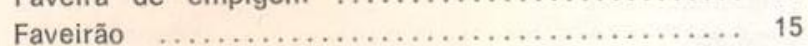

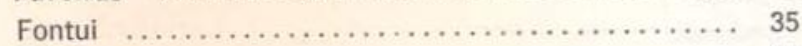

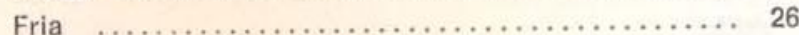

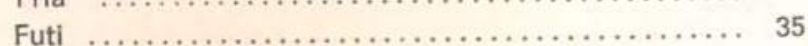

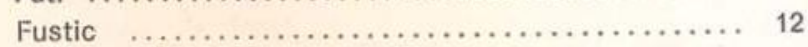

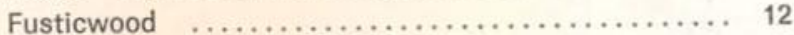

Fustiuholz $\ldots \ldots \ldots \ldots \ldots \ldots \ldots \ldots \ldots \ldots \ldots \ldots \ldots \ldots \ldots \ldots \ldots \ldots \ldots \ldots, 12$

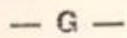

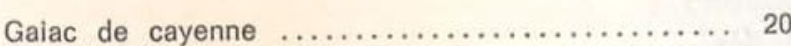

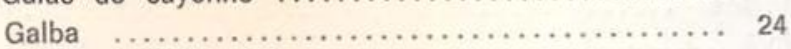

Gale bagasse $\ldots \ldots \ldots \ldots \ldots \ldots \ldots \ldots \ldots \ldots, 16$

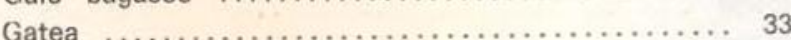

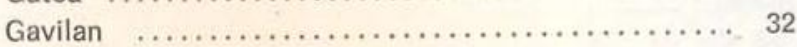

Gedoe ................................. 41

Geles habbes ........................... 21

Geri habisi ............................ 21

Gladde sapo-ordoe of sawari $\ldots \ldots \ldots \ldots \ldots \ldots \ldots, 38$

Gnakewood ............................ 33 


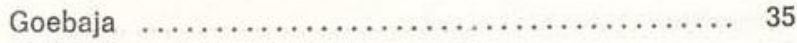

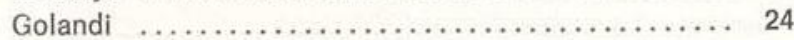

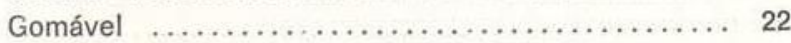

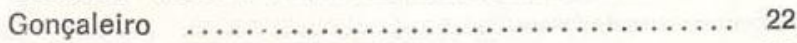

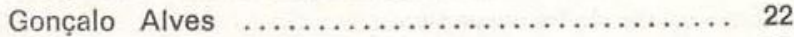

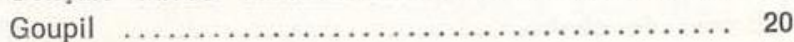

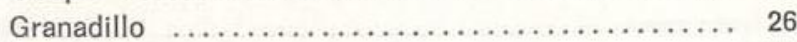

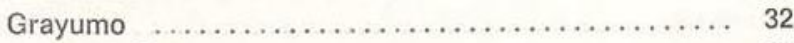

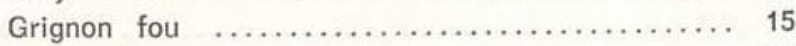

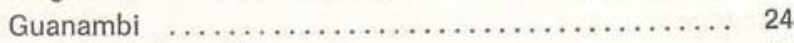

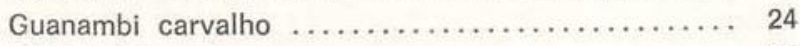

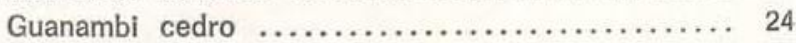

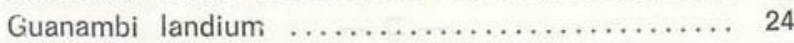

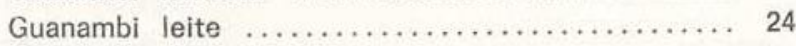

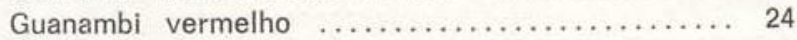

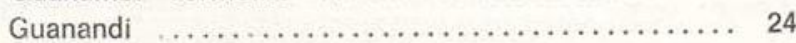

Guanandi carvalho ..................... 23

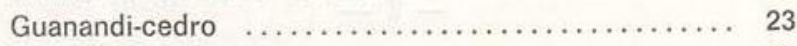

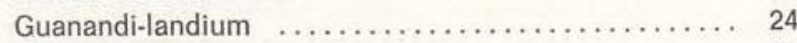

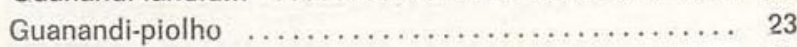

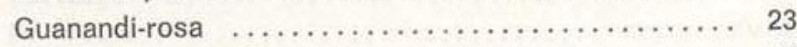

Guananim vermelho $\ldots \ldots \ldots \ldots \ldots \ldots \ldots \ldots \ldots \ldots$

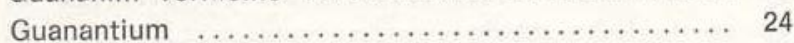

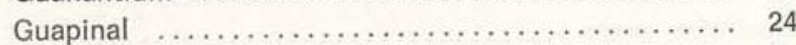

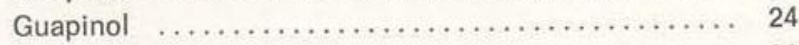

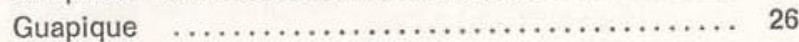

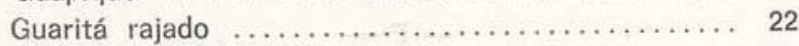

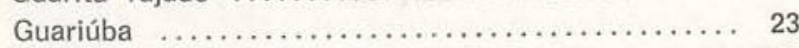

Guariúba amarela $. . \ldots \ldots \ldots \ldots \ldots \ldots \ldots \ldots . \ldots \ldots$

Guitarrero ......................... 32

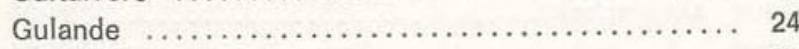

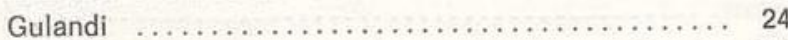

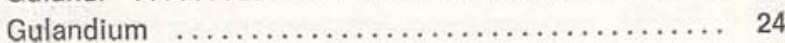

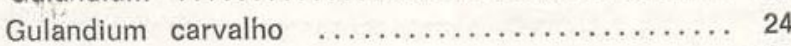

Gumbeira ......................... 32

\section{$-\mathrm{H}-$}

Haw

15

Honduras mahogany $\ldots \ldots \ldots \ldots \ldots \ldots \ldots \ldots \ldots . . \ldots \ldots$

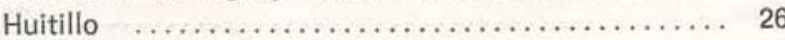

\section{$-1-$}

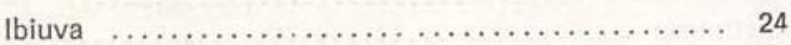

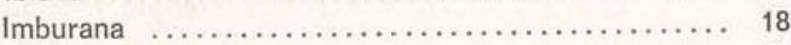

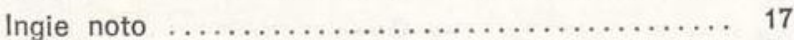

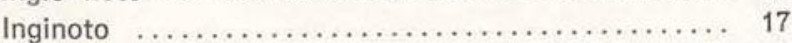

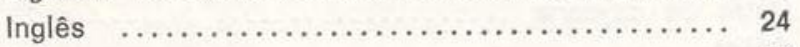

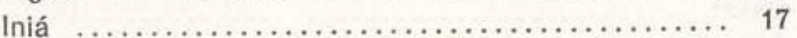

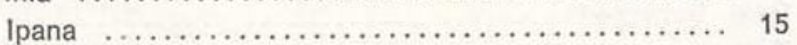

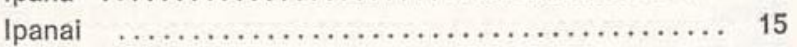

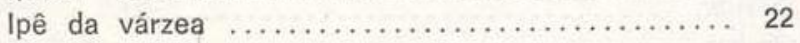

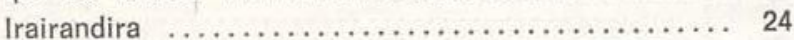

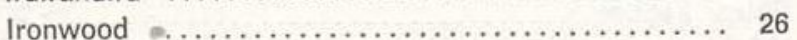

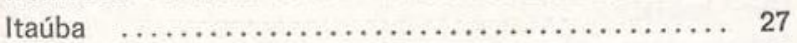

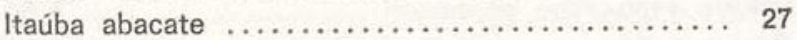

Itaúba amarela ...................... 27

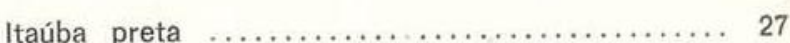

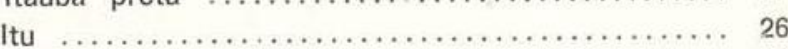

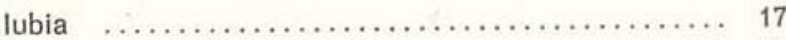

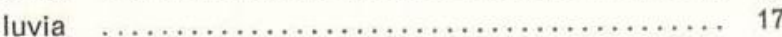

\section{$-\mathbf{J}-$}

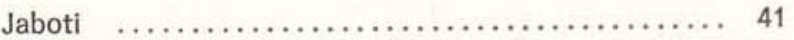

Jaboti da terra firme $\ldots \ldots \ldots \ldots \ldots \ldots \ldots \ldots . \ldots . \ldots 4$

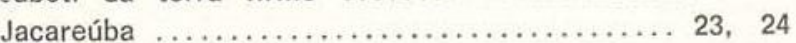

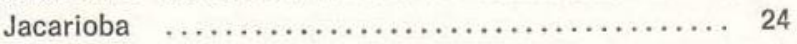

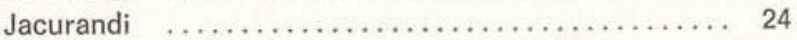

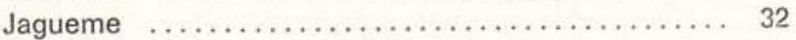

lagueme macho $\ldots \ldots \ldots \ldots \ldots \ldots \ldots \ldots \ldots \ldots \ldots, 32$

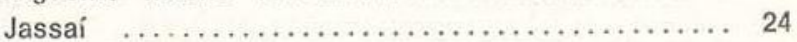

Jassie noedol ....................... 35

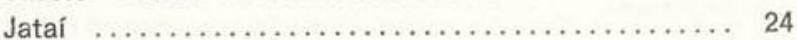

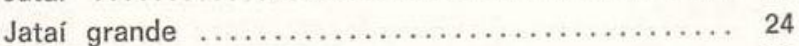

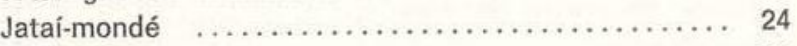

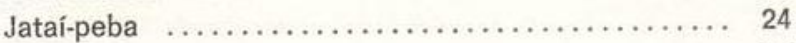

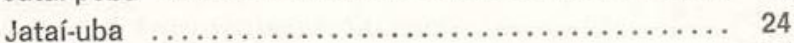

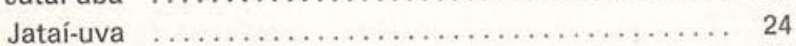

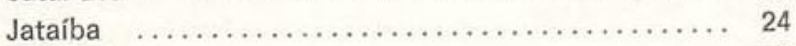

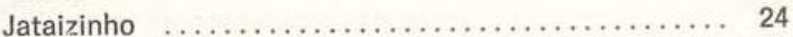

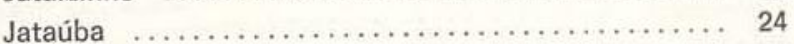

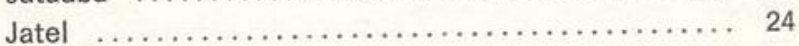

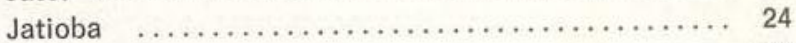

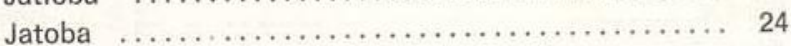

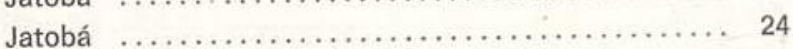

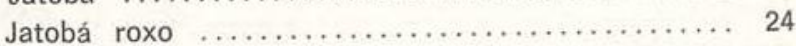

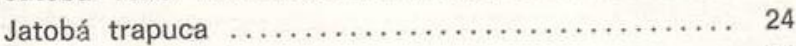

Jatobá verdadeiro $\ldots \ldots \ldots \ldots \ldots \ldots \ldots \ldots \ldots \ldots . \ldots \ldots$

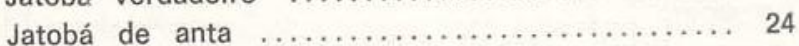

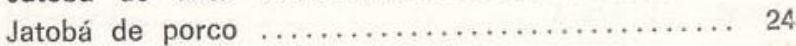

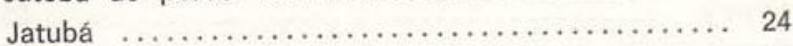

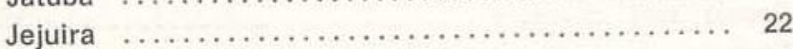

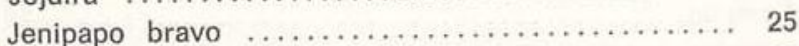

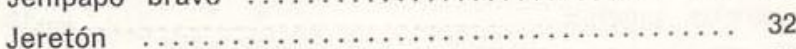

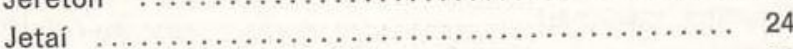

Jetai de Pernambuco ................... 24

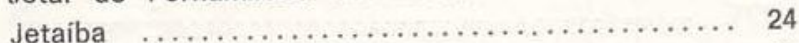

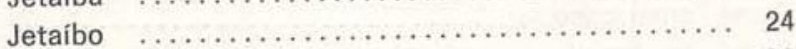

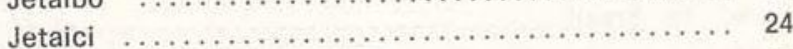

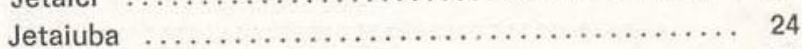

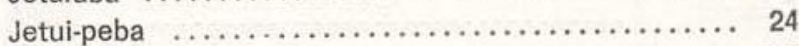

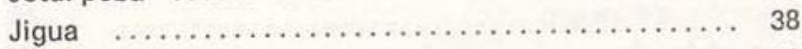

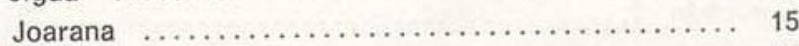

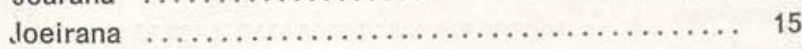

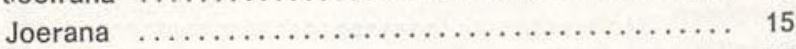

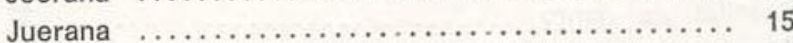

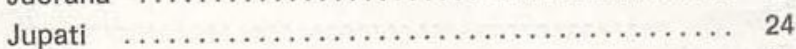

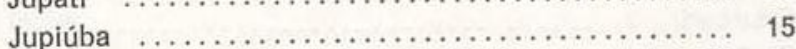

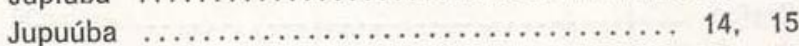

Jutai $\ldots \ldots \ldots \ldots \ldots \ldots \ldots \ldots \ldots \ldots \ldots \ldots \ldots \ldots \ldots \ldots \ldots \ldots \ldots \ldots \ldots \ldots \ldots \ldots, 24,26$

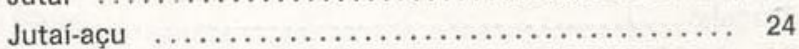

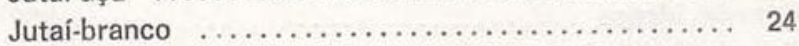

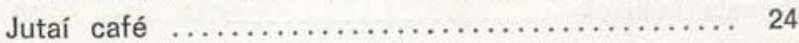

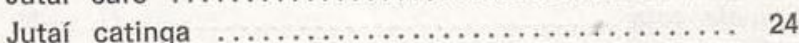

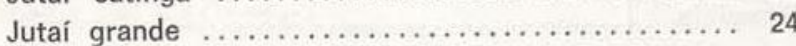




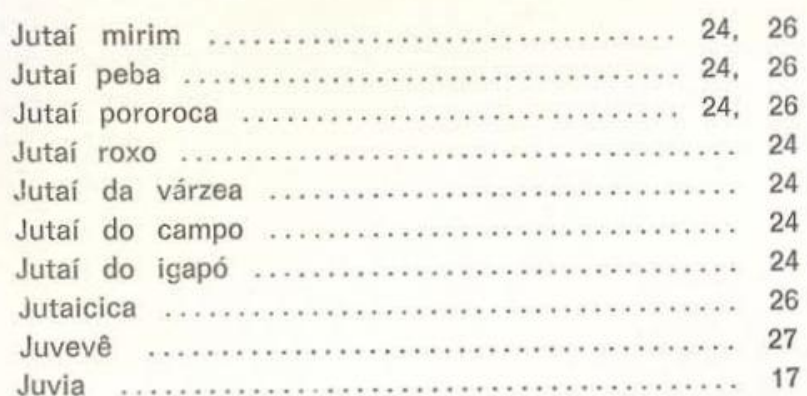

$-\mathrm{K}-$

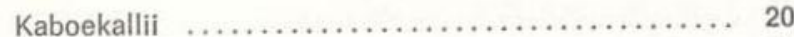

Kabukalli .......................... 20

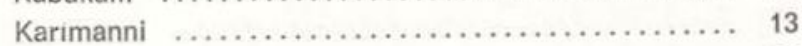

Karohoro ......................... 32

Kasabahoedoe ........................ 32

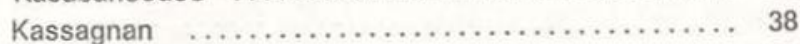

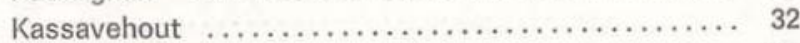

Koemaroe ........................... 20

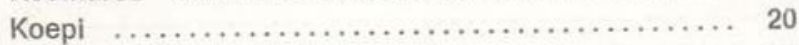

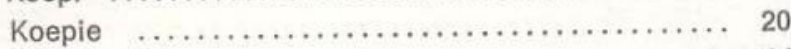

Koerali of koerara $\ldots \ldots \ldots \ldots \ldots \ldots \ldots \ldots \ldots, 24$

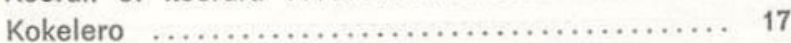

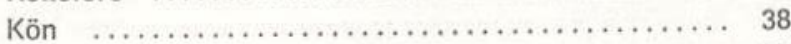

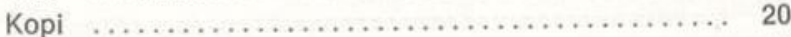

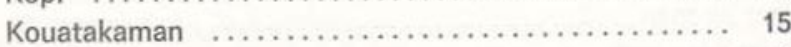

Kwanie ......................... 41

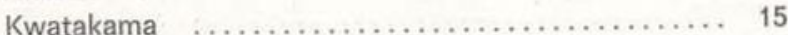

\section{$-\mathbf{L}-$}

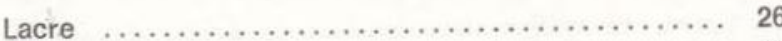

Lacre da mata virgem .................. 44

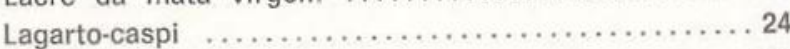

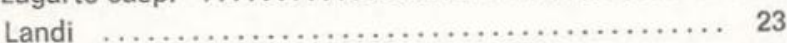

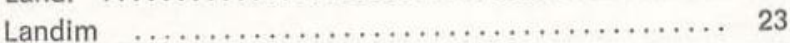

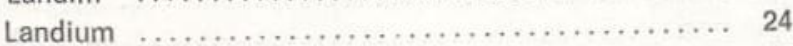

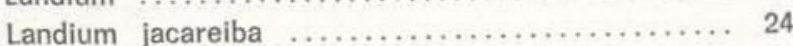

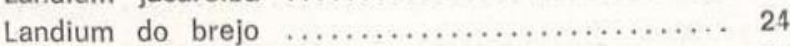

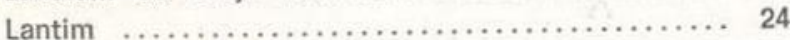

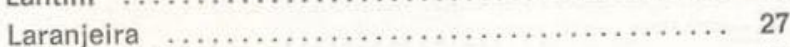

Leche amarilo $\ldots \ldots \ldots \ldots \ldots \ldots \ldots \ldots \ldots \ldots \ldots \ldots$

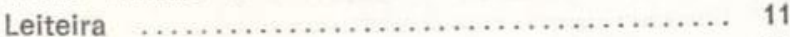

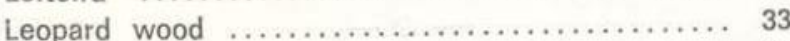

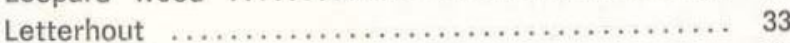

Lotterwood .......................... 33

Lettre mouchette $\ldots \ldots \ldots \ldots \ldots \ldots \ldots \ldots \ldots \ldots, 33$

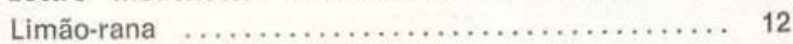

Limão-rana amarelo $\ldots \ldots \ldots \ldots \ldots \ldots \ldots \ldots \ldots \ldots \ldots \ldots \ldots \ldots \ldots \ldots$

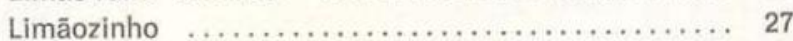

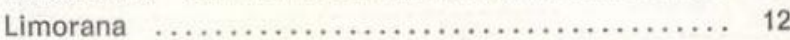

Locus ............................... 24

Locust ............................... 24

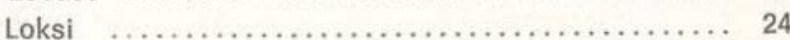

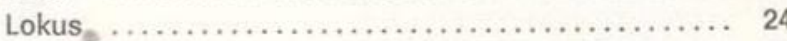

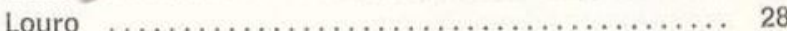

Louro amarelo do igapó ................. 28

Louro itaúba $\ldots \ldots \ldots \ldots \ldots \ldots \ldots \ldots \ldots \ldots \ldots \ldots \ldots \ldots$

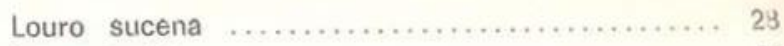

Louro tachi ........................ 41

Louro da várzea $\ldots \ldots \ldots \ldots \ldots \ldots \ldots \ldots \ldots \ldots \ldots, 28$

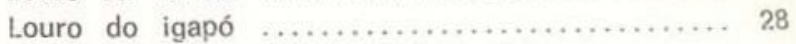

$-\mathrm{M}-$

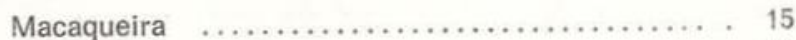

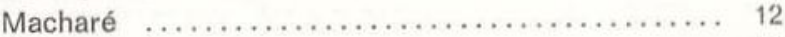

Maçaranduba ............................ 28

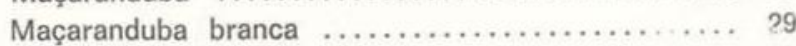

Maçaranduba verdadeira $\ldots \ldots \ldots \ldots \ldots \ldots \ldots \ldots . \ldots \ldots$

Mafua .............................. 15

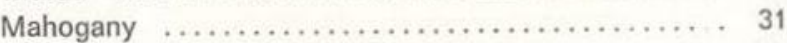

Mahogany Honduras .................... 31

Male bois macaque ..................... 15

Manica de porco ..................... 27

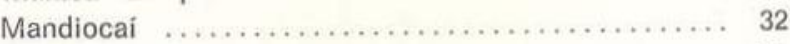

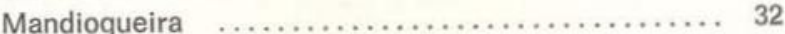

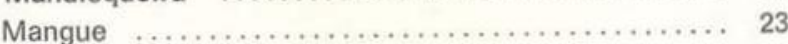

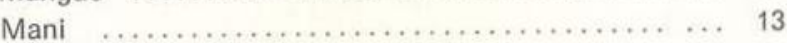

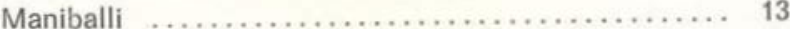

Manil ............................. 13

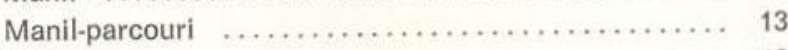

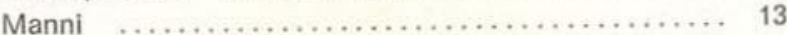

Mara ............................ 31

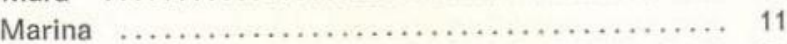

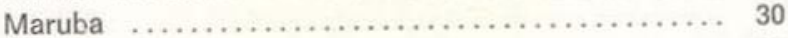

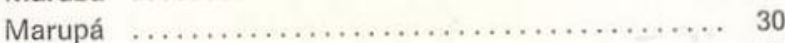

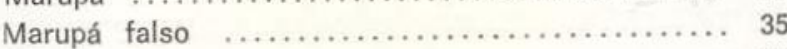

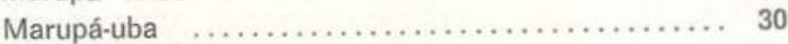

Marupá-uba-falso ..................... 31

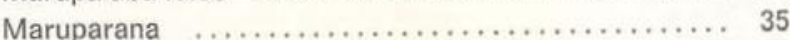

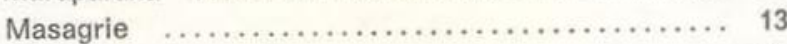

Mataki ............................... 13

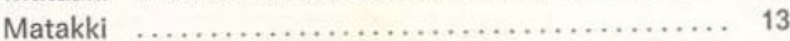

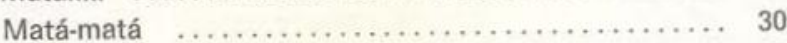

Matá-matá rosa ....................... 30

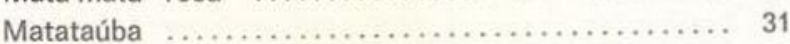

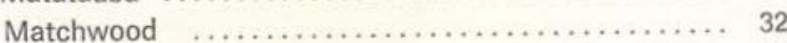

Match-wood .......................... 32

Mimba-branca ........................ 43

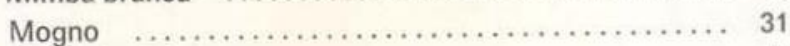

Mogno-brasileiro ..................... 31

Molongu da mata $\ldots \ldots \ldots \ldots \ldots \ldots \ldots \ldots \ldots, 42$

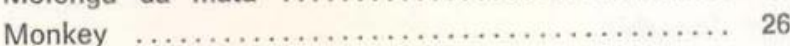

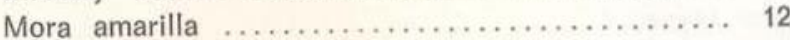

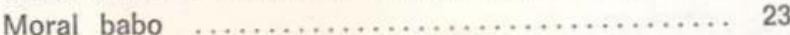

Moral comida de mono $\ldots \ldots \ldots \ldots \ldots \ldots \ldots \ldots . \ldots \ldots$

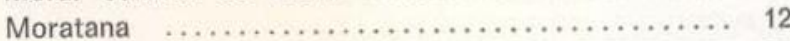

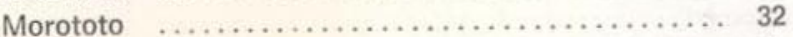

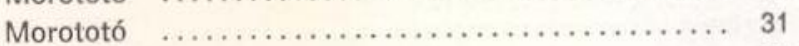

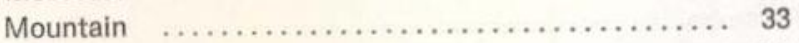

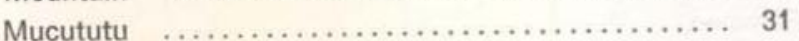

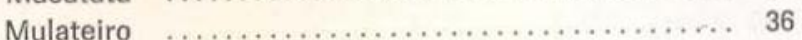

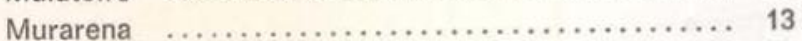

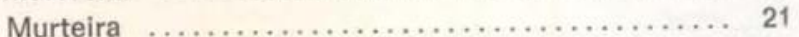

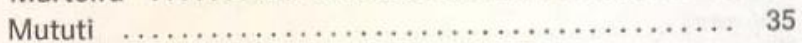

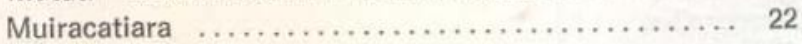

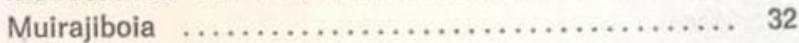




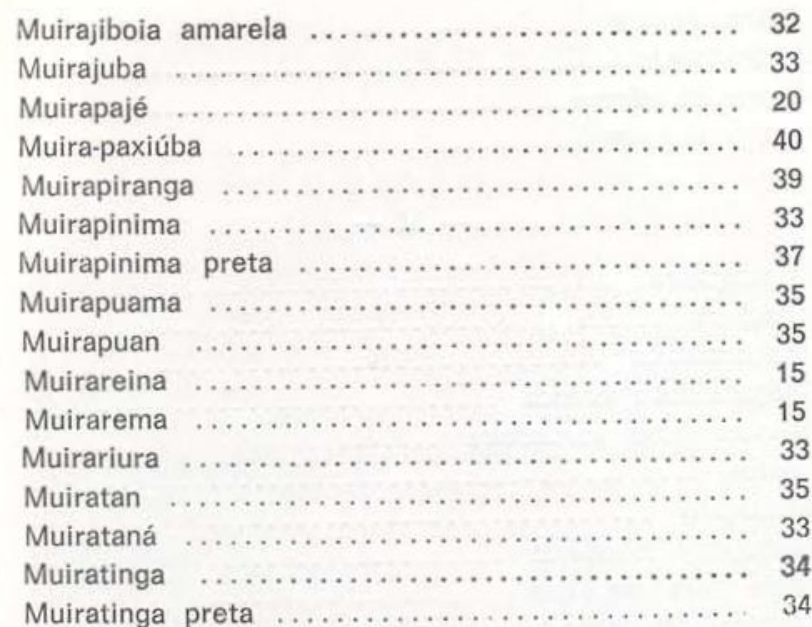$$
-\mathrm{N}-
$$

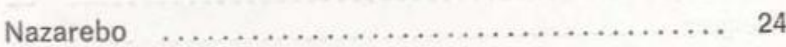

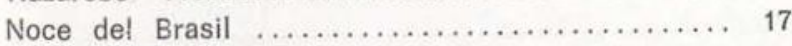

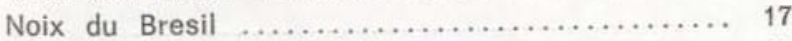

Noz do Brasil ........................... 17

Nuez del Brasil ........................ 17

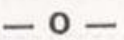

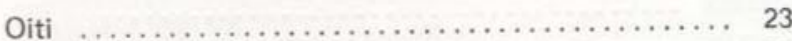

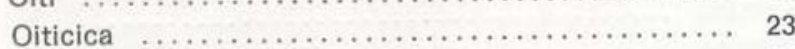

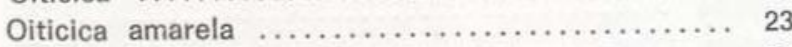

Oiticica da mata ....................... 23

Olandi $\ldots \ldots \ldots \ldots \ldots \ldots \ldots \ldots \ldots \ldots \ldots \ldots \ldots \ldots \ldots, 23,24$

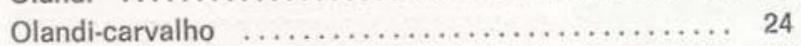

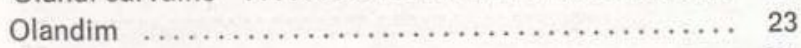

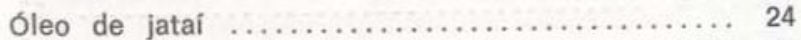

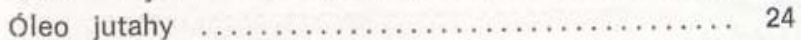

Olla de mico ........................... 17

Orumo macho $\ldots \ldots \ldots \ldots \ldots \ldots \ldots \ldots \ldots \ldots, 32$

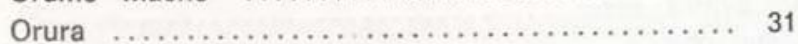

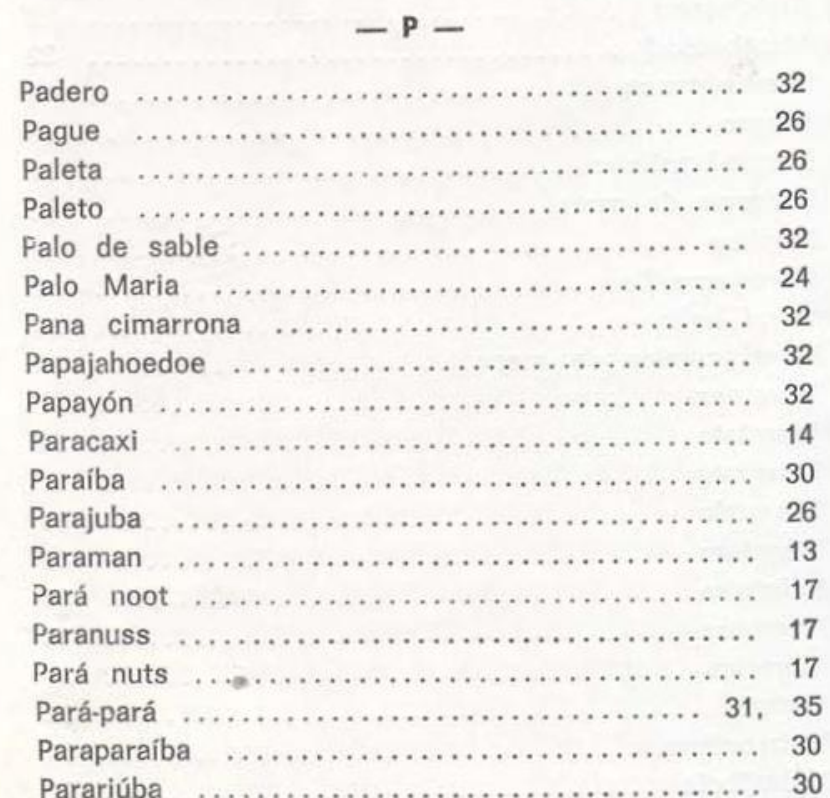

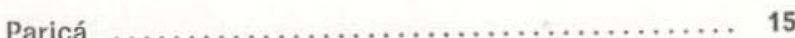

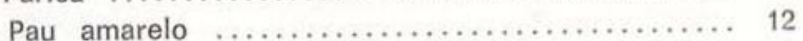

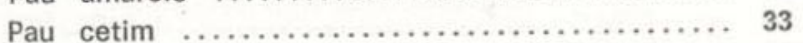

Pau d'arco $\ldots \ldots \ldots \ldots \ldots \ldots \ldots \ldots \ldots \ldots \ldots \ldots \ldots, \quad 36$

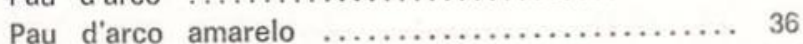

Pau feno ............................... 26

Pau Gonçalo $\ldots \ldots \ldots \ldots \ldots \ldots \ldots \ldots \ldots \ldots \ldots . . . \ldots \ldots, 22$

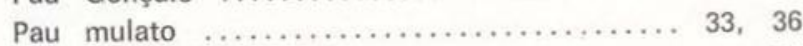

Pau mulato da terra firme $\ldots \ldots \ldots \ldots \ldots \ldots \ldots . . \ldots \ldots$

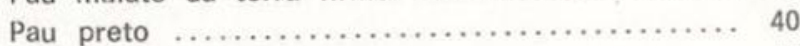

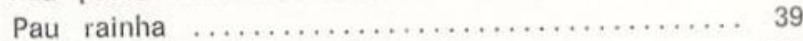

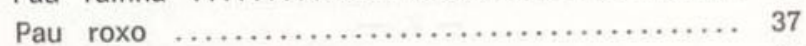

Pau roxo da terra firme $\ldots \ldots \ldots \ldots \ldots \ldots \ldots . . \ldots \ldots$

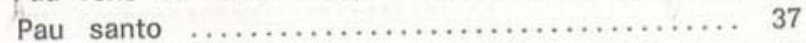

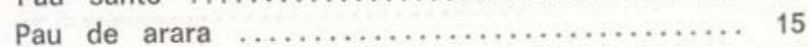

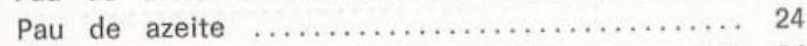

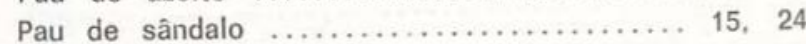

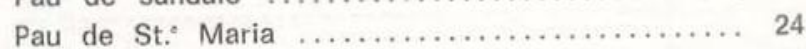

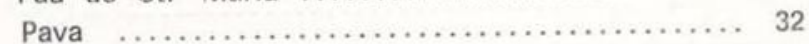

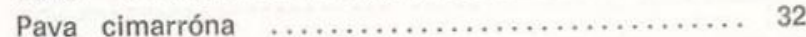

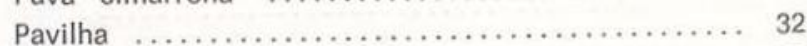

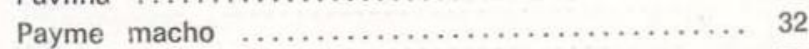

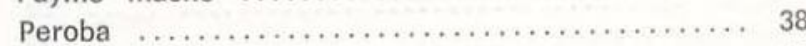

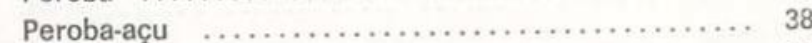

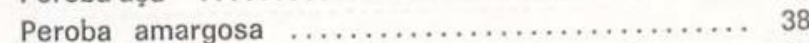

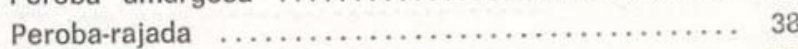

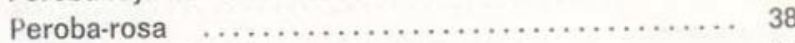

Peruvian mahogany $\ldots \ldots \ldots \ldots \ldots \ldots \ldots \ldots \ldots . \ldots \ldots \ldots$

Phootee ................................... 35

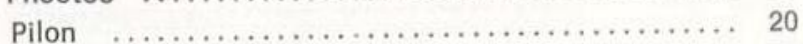

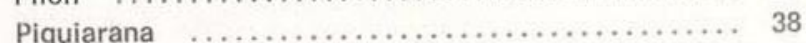

Piquiarana da terra $\ldots \ldots \ldots \ldots \ldots \ldots \ldots \ldots \ldots . \ldots \ldots$

Piquiarana vermelha $\ldots \ldots \ldots \ldots \ldots \ldots \ldots \ldots . . \ldots \ldots$

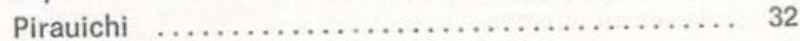

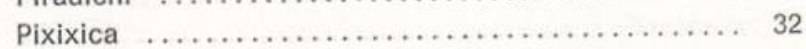

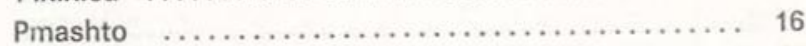

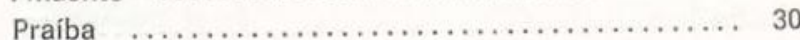

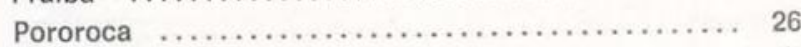

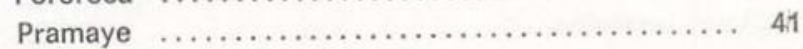

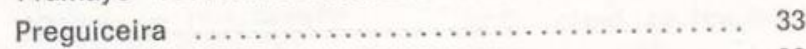

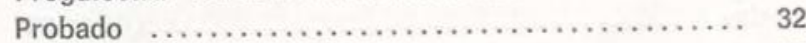

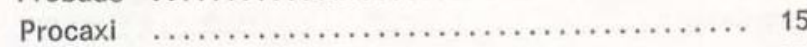

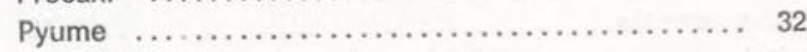

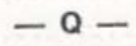

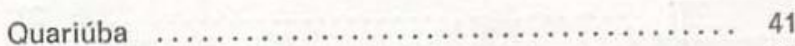

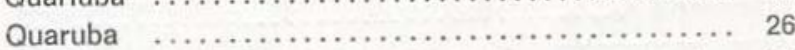

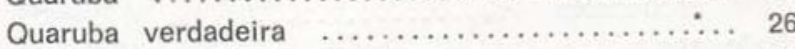

Quaruba vermelha $\ldots \ldots \ldots \ldots \ldots \ldots \ldots \ldots \ldots \ldots, 41$

Quaruba de flores roxas $\ldots \ldots \ldots \ldots \ldots \ldots \ldots . . \ldots \ldots$. 41

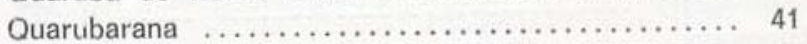

Quarubatinga $\ldots \ldots \ldots \ldots \ldots \ldots \ldots \ldots \ldots \ldots, 41$

Quebra machado ...................... 24, 26

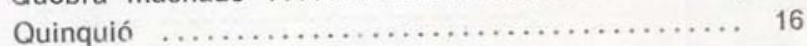

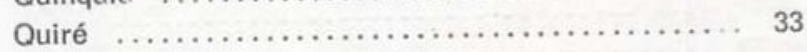

Rabo de arara ............................ 14 
Rainha

Rode locus $\ldots \ldots \ldots \ldots \ldots . \ldots . \ldots . \ldots . \ldots \ldots$

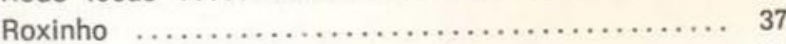

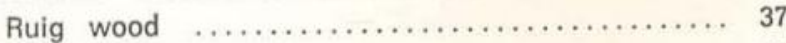

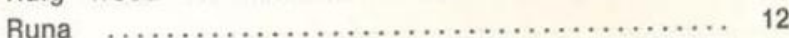

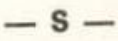

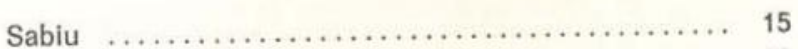

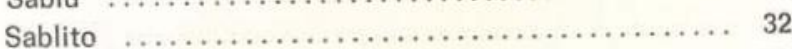

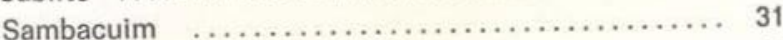

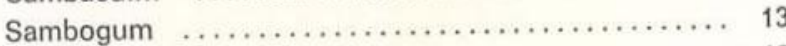

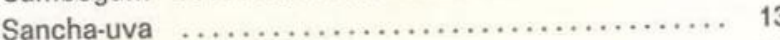

Sangue de boi $\ldots \ldots \ldots \ldots \ldots \ldots \ldots \ldots \ldots \ldots, 39$

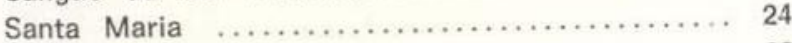

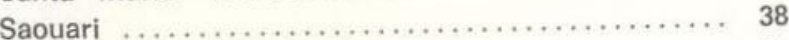

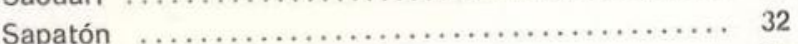

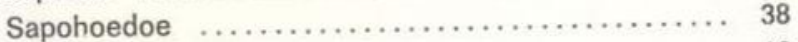

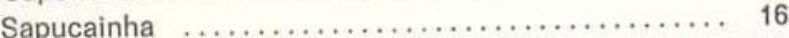

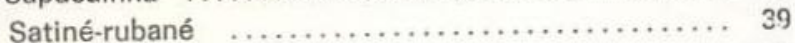

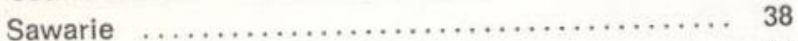

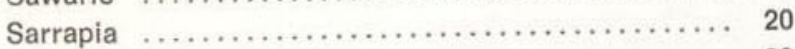

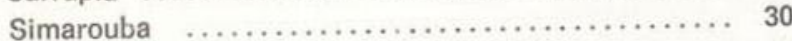

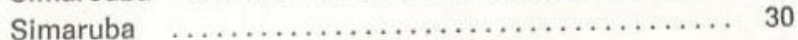

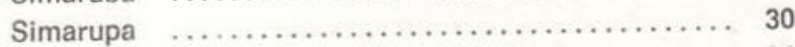

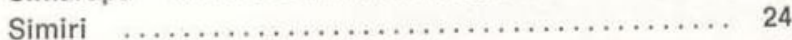

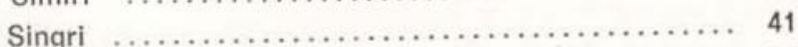

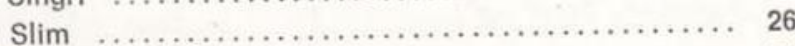

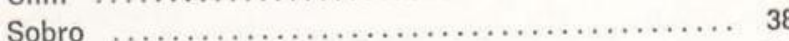

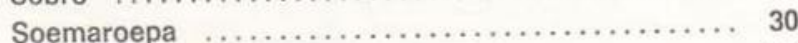

Sota $\ldots \ldots \ldots \ldots \ldots \ldots \ldots \ldots \ldots \ldots \ldots \ldots \ldots, 23$

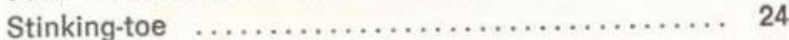

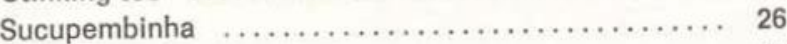

Sucupira $\ldots \ldots \ldots \ldots \ldots \ldots \ldots \ldots \ldots \ldots \ldots \ldots, 40$

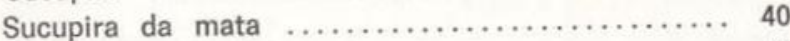

Sucupira preta ..................... 40

Sucupira da terra firme $\ldots \ldots \ldots \ldots \ldots \ldots \ldots \ldots .40$

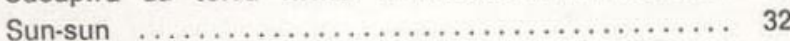

$-\mathrm{T}-$

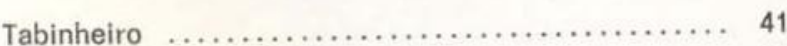

Tachi $\ldots \ldots \ldots \ldots \ldots \ldots \ldots \ldots \ldots \ldots \ldots \ldots, 41$

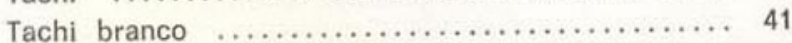

Tachi preto $\ldots \ldots \ldots \ldots \ldots \ldots \ldots \ldots \ldots \ldots \ldots \ldots \ldots, 41$

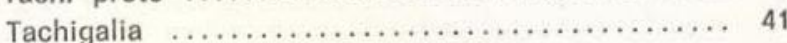

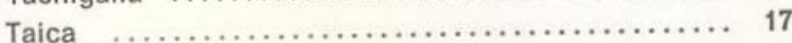

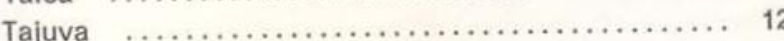

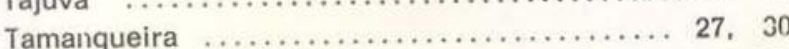

Tamanqueira da terra firme $\ldots \ldots \ldots \ldots \ldots \ldots . . \ldots 27$

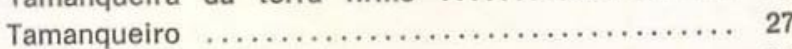

Tamarindo de montanā $\ldots \ldots \ldots \ldots \ldots \ldots \ldots \ldots . \ldots \ldots$

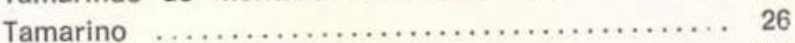

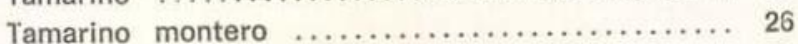

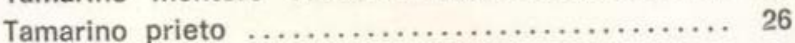

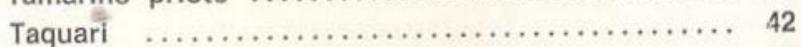

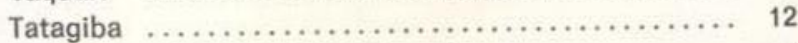

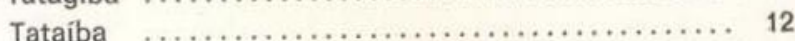

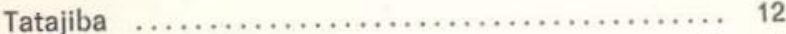

Tatajuba ......................... 12, 16

Tatajuba de espinho $\ldots \ldots \ldots \ldots \ldots \ldots \ldots \ldots \ldots . \ldots \ldots$

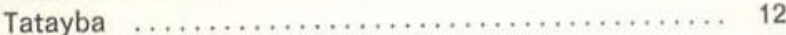

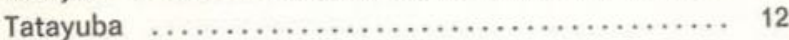

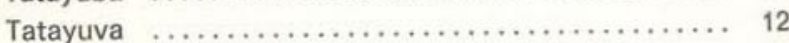

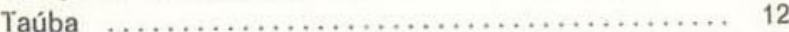

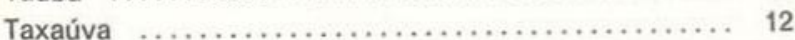

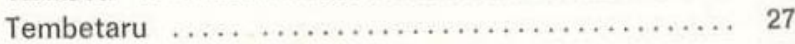

Tento ............................ 42

Teteka ............................. 17

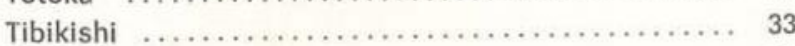

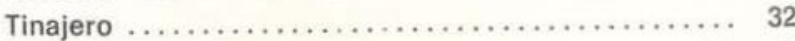

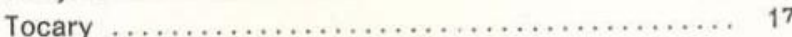

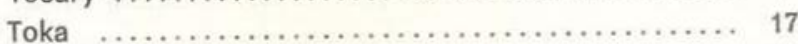

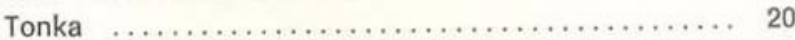

Totoka ................................ 17

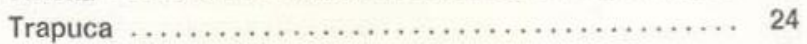

Trompo-huayo $\ldots \ldots \ldots \ldots \ldots \ldots \ldots \ldots \ldots \ldots \ldots \ldots \ldots \ldots$

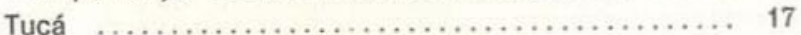

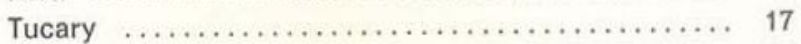

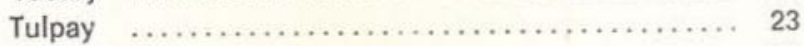

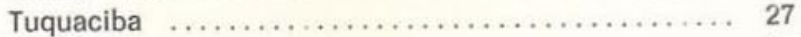

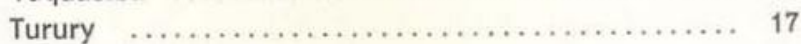

$$
-\mathbf{u}-
$$

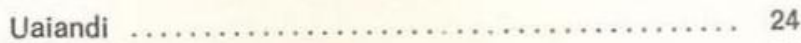

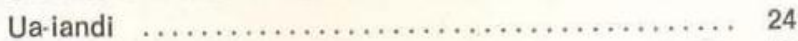

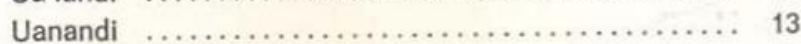

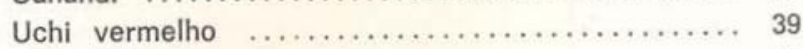

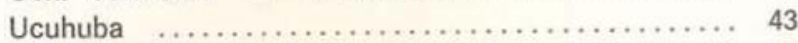

Ucuúba $\ldots \ldots \ldots \ldots \ldots \ldots \ldots \ldots \ldots \ldots \ldots$ 30, 39, 43, 44

Ucuúba branca $\ldots \ldots \ldots \ldots \ldots \ldots \ldots \ldots \ldots \ldots \ldots, 43$

Ucuúba branca do baixio $\ldots \ldots \ldots \ldots \ldots \ldots \ldots \ldots . \ldots \ldots$

Ucuúba preta $\ldots \ldots \ldots \ldots \ldots \ldots \ldots \ldots \ldots \ldots \ldots, 43$

Ucuúba-punā $\ldots \ldots \ldots \ldots \ldots \ldots \ldots \ldots \ldots \ldots \ldots \ldots \ldots \ldots \ldots \ldots, 44$

Ucuúba vermelha $\ldots \ldots \ldots \ldots \ldots \ldots \ldots \ldots \ldots . \ldots \ldots, 43,44$

Ucuúba da folha grande $\ldots \ldots \ldots \ldots \ldots \ldots \ldots \ldots . \ldots \ldots$

Ucuúba da terra firme ................. 44

Ucuubarana $\ldots \ldots \ldots \ldots \ldots \ldots \ldots \ldots \ldots \ldots 30,39,44,45$

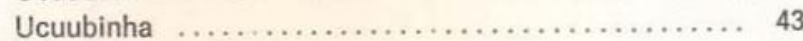

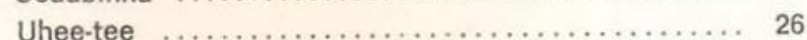

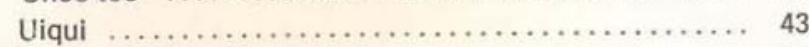

Ullpa-cumalla $\ldots \ldots \ldots \ldots \ldots \ldots \ldots \ldots \ldots \ldots \ldots \ldots, 45$

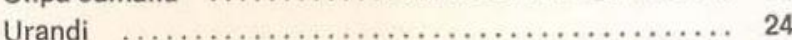

$$
-v-
$$

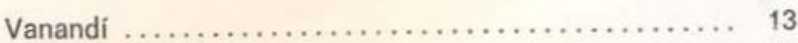

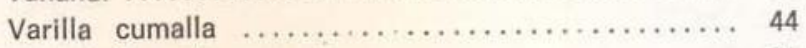

Venezuela mahogany $\ldots \ldots \ldots \ldots \ldots \ldots \ldots \ldots \ldots, 31$

Visgueiro $\ldots \ldots \ldots \ldots \ldots \ldots \ldots \ldots \ldots \ldots \ldots \ldots \ldots \ldots \ldots, 14$

$$
-w-
$$

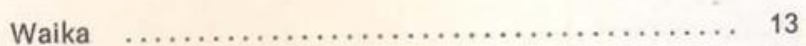

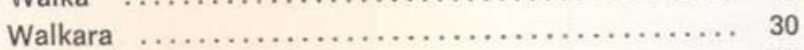

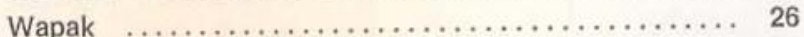

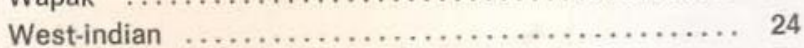

Wild $\ldots \ldots \ldots \ldots \ldots \ldots \ldots \ldots \ldots \ldots \ldots \ldots \ldots \ldots \ldots \ldots \ldots \ldots \ldots, 33$ 


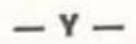

Ya

Yagrume

Yagrume macho

Yarumero

Yagrumo macho

Yarumo macho
Yarumo de savana

Yatayba yutahy

Yrumero

Yubia

- z -

Zota
32

24

32
32

32

32 


\section{ÍNDICE ALFABETICO DOS NOMES CIENTÍfICOS}

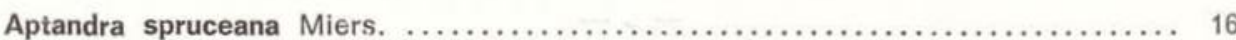

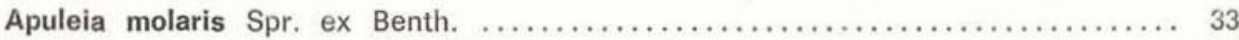

Aspidosperma polyneuron Muell. Arg. $\ldots \ldots \ldots \ldots \ldots \ldots \ldots \ldots \ldots \ldots \ldots \ldots \ldots \ldots \ldots \ldots, 38$

Astronium fraxinifolium Schott. . . . . . . . . . . . . . . . . . . . . . . . . 22

$$
\text { - B - }
$$

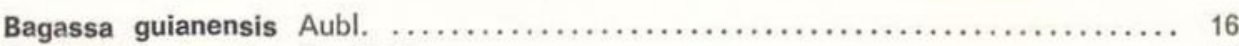

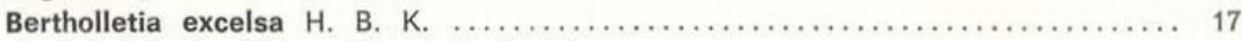

Bocageopsis multiflora (Mart.) R. E. Fries ........................... 21

Bowdichia nitida Spr. ex Benth. ................................. 40

Brosimum guianensis Aubl. . . . . . . . . . 33

Brosimum rubescens Taub. ...................................... 39

Brosimum utile subsp. ovatifolium (Ducke) C. C. Berg. ........................ 11

$$
-\mathbf{C}-
$$

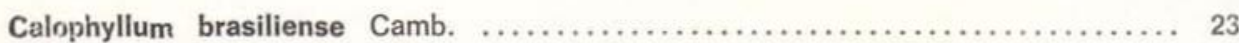

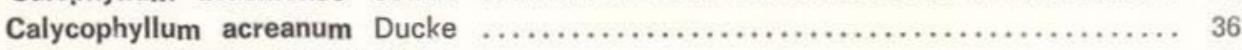

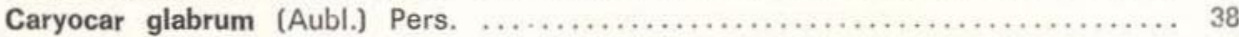

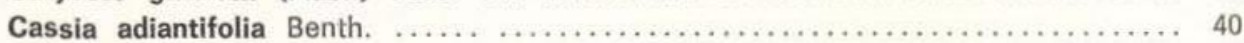

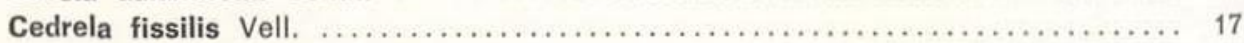

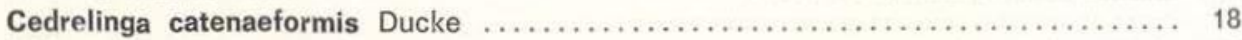

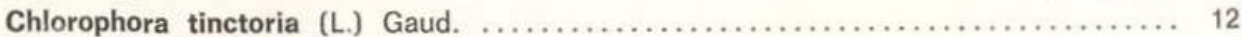

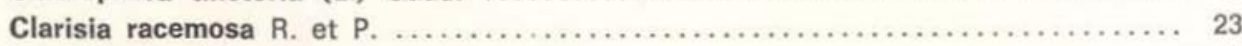

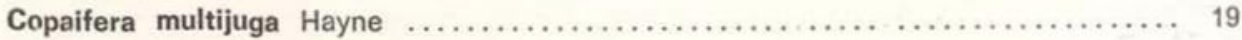

$$
-\mathbf{D}-
$$

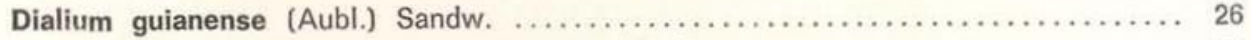

Didymopanax morototoni (Aubl.) Decne \& Planch. ......................... 31

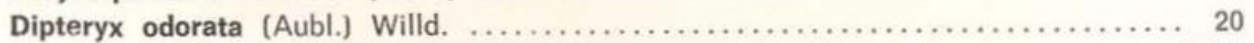

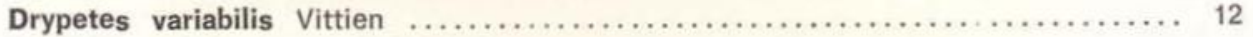

$$
-\mathbf{E}-
$$

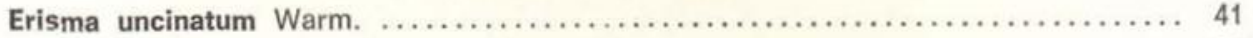

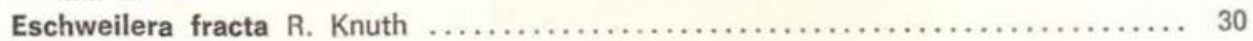

$$
-\mathbf{G}-
$$

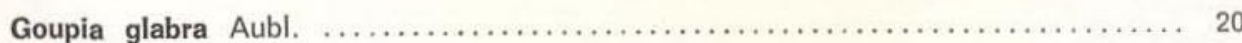

$$
-\mathbf{H}-
$$

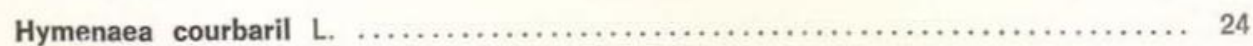

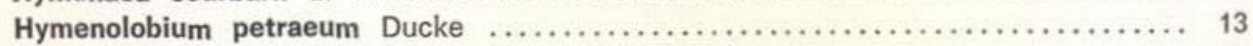

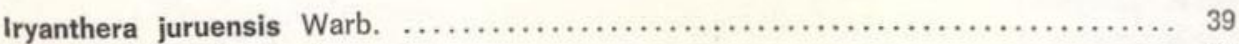

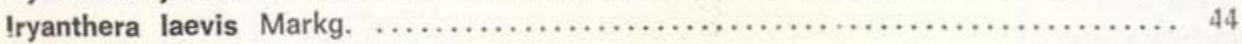

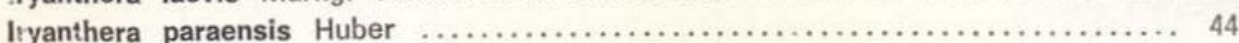

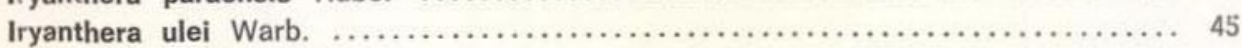




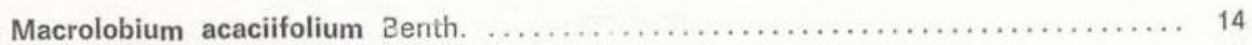

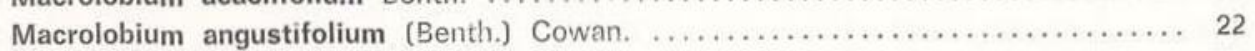

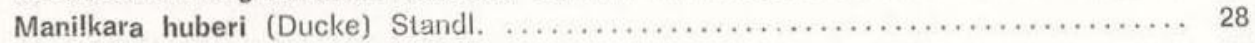

Maquira coreacea (Kosterm) C. C. Berg. ............................. 34

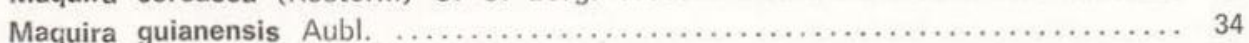

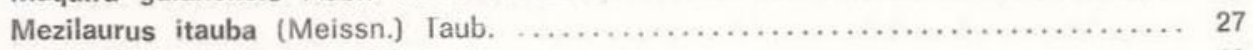

Miconia poeppigii Trian. $\ldots \ldots \ldots \ldots \ldots \ldots \ldots \ldots \ldots \ldots \ldots \ldots \ldots \ldots \ldots \ldots \ldots \ldots \ldots \ldots \ldots \ldots \ldots, 42$

\section{$-\mathrm{N}-$}

Nectandra amazonum Ness

$$
-0-
$$

Ormosia paraensis Ducke

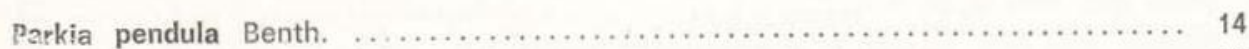

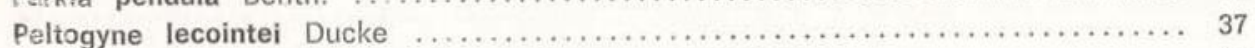

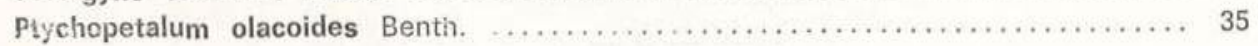

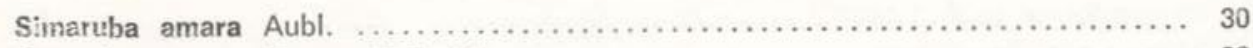

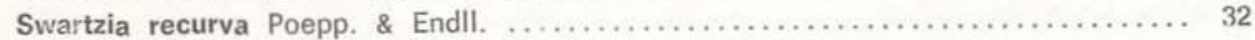

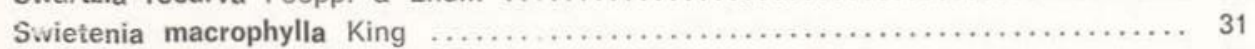

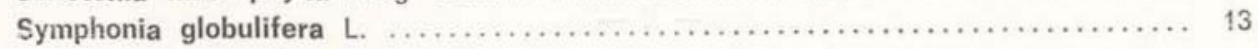

$$
-\mathbf{T}-
$$

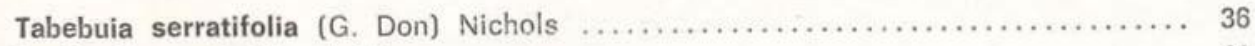

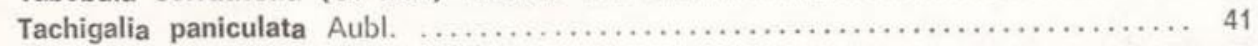

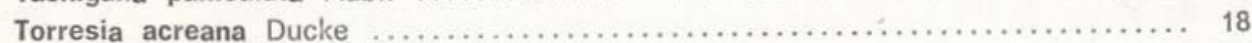

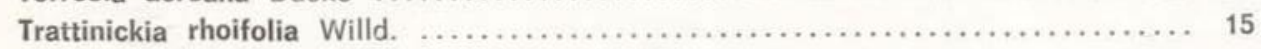

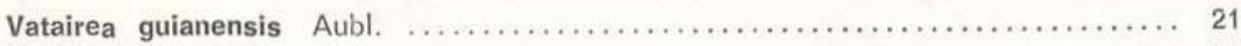

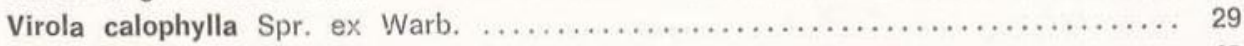

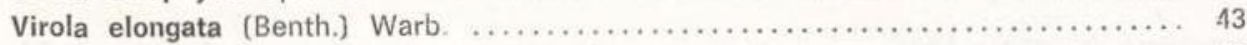

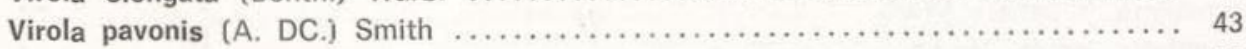

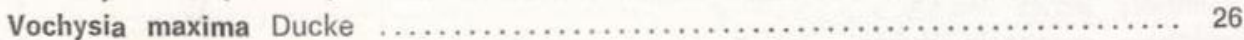

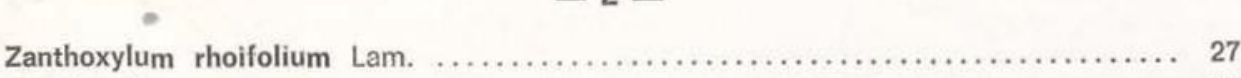

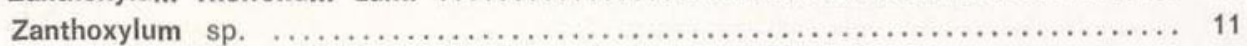

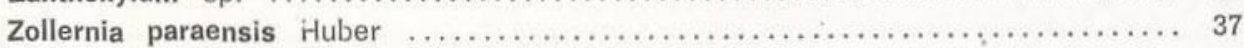




\section{ERRATA}

1 - PS. 9. o desenho esquemático 8 e 9, são do tipo de parênquima apotraqueal.

2 - Na tabela das características físicas e mecânicas de algumas espécies, "Os asteristicos significam:

(*) - Brotero et al., 1956

(**) - Outras fontes.

ACTA AMAZONICA Ano IX Março 1979 № 1 Suplemento

Madeiras do Município de Aripuanã e suas Utilidades (Mato Grosso)

Arthur A. Lovreiro

Pecro L. Braga Iisboa 